\title{
COMPARATIVE OSTEOLOGY AND PHYLOGENY OF THE FAMILY ARDEIDAE
}

\author{
By \\ CLAUDE T. ADAMS \\ A DISSERTATION PRESENTED TO THE GRADUATE COUNCIL OF \\ THE UNIVERSITY OF FLORIDA \\ IN PARTIAL FULFILMENT OF THE REQUIREMENTS FOR THE \\ DEGREE OF DOCTOR OF PHILOSOPHY
}

UNIVERSITY OF FLORIDA

June, 1956 
TABLE OF CONTENTS

Page

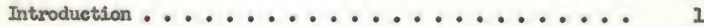

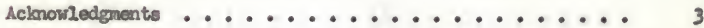

Materials and methods ................... 4

Measurements .............. 5

Ratios ....................... 5

Gualitative considerations ........... 6

Quantitative characters .............. 8

Qralitative aharacters ................... 23

Conclusions .......................... 37

Intergeneric relattonships $\ldots \ldots . . . . . .37$

Generic diagnoses................. 40

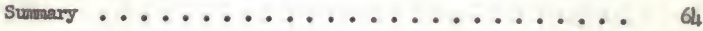

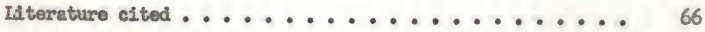

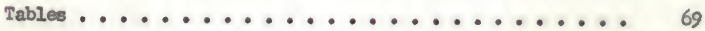

Plates ............................ 257

Biographical sketch ................ 166 


\section{INTRODUCTION}

The Ardeldae, or herons, form one of the two fandiles of birds conprised in the suborder Ardeae, order Ciconilformes. The only other fanily referred to this suborder is Cochlearlidae, the boat-billed herons. Mive additional fandlies are Included in other suborders of the order Ciconifformes (Peters, 1931). These are Balaenicipitidse, Scopidae, Ciconildae, Thresklornithidae, and Phoenicopterldee. The fanily Ardeldae is cosmopolitan in 1ts distribution, but the ranges of the other fanilies are considerably restricted.

The earliest fossil records for the farily are from the Eocene, although relatively few remains are known (Lambrecht, 1933). Barliest records in North Americe are 1ikewlse from the Eocene. They are Foceornis ardetta Shufeldt and Botauroldes parvis Shufeldt, both from the Bridger formation of Wyondng. Foceomis ardetta, deacribed from the anterior portion of the sternum, is a relatively amall bird approximately the size of our modern Hydranassa or Leucophoyx. Botauroldes parvus, described from a fragmentary tarsonetatarsus, is considerably smaller then Ixobrychus, and is sald to be neither typieal heron nor true bittern. Because of its intermediato position it has been referred to as a stem form of the modern herons.

The latest revisor of the fandly Ardeldae divides it into two subfand11es, Ardeinae, the true herons, and Botaurinae, the bitterns (Peters, 1931). To these two subfandlies are referred thirtymone genere and sixty-two species. No, less than elghteen of the genera are monotyple with the average number of species per genus for the entire fanily being 
only 2.0. Andes is the largest genus with ten species.

The high proportion of monotypic or small genera does little to express interrelationships of the forms. Under the present systen the genera have been set up entirely on the basis of external characters, and In many cases on such epheseral characters as the seesonal breeding plumes. As the internal morpholopy of the fandly has never been investigated at the generic or speciflc level, it seemed probable that a study of the skeleton might yield information of value in deternining intraspecific relationshipe and in dofining the generic limits.

Cochlearius, the boat-billed heron, has been included in this study beceuse of its texconomic position in the order Ciconilformes. This monotyple genus is currently assigned to the fantly Cochlearildae, the second family of the suborder Ardeae. 


\section{ACKNOWLDOMHFNS}

I wish to acknowlodge my Indebtedness to those who have been holpful in the preparation of this paper. The patience, able assistence, sound judgnent, and ldind encouragement of Dr. Plerce Brodkorb, the cheirman of my supervisory conalttee is most deeply appreclated. To the other members of ag counittee, Drs. A. F. Caxr, Coleman J. Coln, E. Ruffin Jones, Jr., and John H. Davis, I wlsh to express mo deepest appreclation for their kdnd words of enoouragement, coments, and criticisme in the preparation of this paper.

For the loan of skeletal specimens, I an obligated to Dr. Herbert Friedmann, U. S. National Museung Dr. Dean Amedon, American Museum of Naturel History; Dr. Frank A. PItelka, Museun of Vertebrate Zoology, University of Callfornia; Dr. Robert W. Storer, Museum of zoology, University of Miehigan; Dr. Harrison B. Tordoff, Museum of Natural History, University of Kansas; Dr. Hildegarde Howard, Loe Angeles County Museum; and Dr. Finn Salomonsen, Universitatets Zoologiske Museun, Copenhagen. I an Indebted to the following individuals for the oxchange of specimens: Dr. Alexander Wolsld, UNFSCO, DJakarta, Indonesia; Dr. H. Eliott MCCluro, U. S. Argy; and Dr. Naganichi Kuroda, Tokyo, Jamen.

Lastiy, I express m sincerest appreciation to my wife Martha, and mo ohildren, C. T., Jr, and Julie, whose patience and devotion have been my inspiration. 
A total of 326 skeletons were used in this study. These were borrowed from museuns and Individuals, obtained through the medium of exw change, or collocted by the writer locally. Of the thirty-one genere and sixty-two species currently assigned to the fanily, the following twentyone genere, and fortyntwo species were examineds

Ardea sunstrana Rarfles, Ardea goliath Crotsschnar, Ardea melanocephala V1gors and Children, Ardea cinerea Linne, Ardea herodias tregenzal Court, Ardee herodias herodias Linne, Ardes occidentelis Audubon, Ardea coco1 Linne, Andea pacifice Latham, Andea purpurea IAnne, P17herodius pileatus (Boddaert), Butorides Virescens virescens Linne, Butorides strlatus atricapilius (Afzeltus), Exythocnus rufiventris (Sundevall), Morida caerulea (ISinne), Ardeola ralloldes (Scopoll), Ardeola becchus (Bonaparto), Andeola speciosa (Horsilield), Bubulcus 1bis 1bis (IAnno), Dichromanassa rufoscens rufescens (Gmelin), Casmerodius albus modeatus (J. E, Grav), Casmerodius albus egretta (Omelin), Egrette garzetta garretta (ISnno), Esatta internedia Deignan, Leucophorx thura thula (Molina), Hydrenassa trlcolor ruflcollis (Gosse), Syrigna sibilatrix (Teaninck), Nycticorax mycticorax nycticorax (ISmne), Nycticorax nycticorex hoactli (Gmelin), Nreticorax calodonicus caledonicus (Onelin), llrctenassa Vlolaces V1olacea (IInno), Nyctanassa V1olaces Dancrofts Huey, Gorsachius malanolophus (Rarfles), Tigrtornis leucolopha (Jardine), Tlerisona Iineaturs linestum (Boddsert), TIgrisoma mexdeana mexicans Sweinson, Ixobrychus sinangis sinensis (Anelin), Ixobrychus involueris (Vieillot), Irobrychus exdis exil1s (Gmelin), Isobrychus cinnomoneus (Onelin), Isobrychus strumis 
(Wagler), Botaurug stellaris stellaris (Linne), Botaurus lentiginosus (Vontagu), and Cochlearius cochlearius cochlearlus (Iime) of the fandly Cochlearildae.

Measurenents. Eighteen measurenents wore taken on each specimen. All measurenents, except those of the preorbital and postorbital, represent the overall lengths of their respective elements. The preorbitel and postorbital measurewents represent the width of that particular reglon of the skwll. The descriptions of the messurenents are given in Adans (1952), Beumel (1953), and Glatfelter (1950). Osteological tervinology is that of Howard (1929).

A review of the standard measurements of sise as given in Table 1 shows the inpracticality of basing a texononic or phylogenetic study on these measurenents because of the great variation in sise of the species currentiy assigned to the fandly. It was decided therafore, that ratios would be used, rather then size, as the basis for the comparative study.

Ratios. Twenty-six ratios were computed from the efghteen skeletal measurements. Fech is Iistec? with its moan, standard deviation, com efficient of variation, and their respective standard errors in Table 2.

These ratios are divided into three groups, (1) those dealing with the skill, (2) the intramombral ratios, and (3) the intermenbral ratios. Those of the skull were used to indicate differences in cranial development and culmen relationahips. Intramembral ratios compare one element of the wing or leg with the renaining elaments of the respective appendage. The ula and tibia were used as standards for the ving and leg ratios, respectivelj. Intermembral ratios compare elements of the wing 
to elements of the leg.

The intermembral and intramembral ratios were computed to show differences in structural modifications that might be correlated with the Iife history of a given species. Aloo these ratios might be correlated with the pattern of Plight of some of the apecies. Through these two factor, these data way eventually be correlated with the ecology of the individual in some future study of the fanily.

Qualitative considerations. Certain qualities of contour and conformation, while measureable, do not lend thenselves readily to such treatinent. These characters have previously been referred to as perceptible differences by Fohon (1952), and as morphologlcal differences by Nelson (1954). The worlos of these two men represent the extremes of methods of osteologicel study. Fehon's method was gross, compared to Nelson's method which was by the use of a stereosoopic inicroscope. Both methods have been useful in this study. The stereoscopic microscope was found to be most useful when gross excenination proved Inadequate.

Beecher (1953) expressed serious doubt as to the taronomfc value of osteologleal characters. However, I hold with Nelson (1954), that muscle scars and bons profections are, ".... In certain cases, very inportant terconoulc characters."

The qualltative characters used in this study deal with just such projections and musele sears as those referred to by Beecher, and Nelson. Some are of a very delicate nature, and others are more durable. The quelitative characters of the skwl are delicate and difficult to preserve. I have attenpted to elininate characters that were not consistent in large 
series of specimens.

The elements of the post-cranial skeleton show profound gualitetive differences. These characters afford sufficient evidence for grouping the species as presented in the following section, and when combined with the quantitative comparisons, they afford the besis for setting up the generic diagnoses. These qualitative characters are given in Plate 2 for ready reforence. 
A review of the coefficients of variation of the skeletal measurements shows a relatively low value, the range being 0.85 per cent for the ulna $\left(\delta^{\prime}\right)$ of Ixobrychus exdils, and the quadrate width $(\delta)$ of IImisoma mexicans to 12.32 por cent for digit II, phalanx 1 ( $\left.\delta^{\circ}\right)$ of Axdea purpurea. The mean coefficient of varlation is 3.85 per cent, which is a relatively low value as compared with sinflar stat1stics of other groups of animals. The twenty $-s 1 x$ ratios were originally calculated on the besis of sex. The sexes were then compared by a roview of the ranges and means of the respective ratios. These comparisons showed that the seres were inseparable because there was couplete or partial overlap of the ranges, and frequently ident1cal means. As a result, the sexes were grouped to give larger samples of rare forms.

A review of the coefletents of variation of the ratios ahows a pattem similar to that of the skeletel moasureaents. The coefflcients of varlation range from 0.31 per cent for the radius/ulna ratio of Bubulcus 1bis to 12.84 per cent for the preorbital/postorbital rat1o of Ardea herodias treganzal. The mean coefficient of variation is 3.25 per cent, approxinately the same as that of the raw siceletal measurements.

Following are the ratios used with their respective abbreviations:

Ska17:

Ratio

Proorbital width/Skull length Preorbital vidth/Postorbital width Preorbitel vidth/Craniun length Postorbital width/Cranium length Pterygold length/Quadrate length Quadrate width/Quadrate length
Abbreviation

Pre/sk

Pre/Post

$\mathrm{Pre} / \mathrm{Cr}$

Post/Cr

Pt/Q1

Qw/Q2 
Intramembral:

Humerus/UIna

Radius/Una

Cerpounetacarpus/U2ns

Digit II, Phalanx I/UIna

Digit II, Phalanx 2/UIna

Fenax/Tibiotarsus

Tarsometatarsus/TIbiotarsus

Hallux/Tibiotarsus
Abbreviation

Hu/ U1

$\mathrm{Ra} / \mathrm{U}$

Gine/U1

$\mathrm{P}-1 / \mathrm{VI}$

$\mathrm{P}-2 / \mathrm{UI}$

$\mathrm{Fe} / \mathrm{MI}$

$\mathrm{Ta} / \mathrm{II}$

He/ $\mathrm{II}$

Intermembral:

\begin{tabular}{|c|c|}
\hline Fermur/thunerus & $\mathrm{Fe} / \mathrm{Hu}$ \\
\hline Fenur/UIna & $\mathrm{Fe} / \mathrm{U}_{2}$ \\
\hline Femur/Carponetacarpus & $\mathrm{Fe} / \mathrm{Cne}$ \\
\hline Tiblotareus/Humerus & Ti/Hu \\
\hline T1blotarsus/UIna & $T 1 / 01$ \\
\hline Tiblotarsus/Carponetacarpus & $\mathrm{TI} / \mathrm{Cnc}$ \\
\hline Tarsometatarsus/Humorus & $\mathrm{Ta} / \mathrm{Hu}$ \\
\hline Tareonetatarsus/UIns & $\mathrm{Ta} / \mathrm{U}$ \\
\hline Tarsometatarsus/Carpometacarpus & $\mathrm{Ta} / \mathrm{Cnc}$ \\
\hline Hallwa/Humerus & $\mathrm{Ha} / \mathrm{Hu}$ \\
\hline Hallwx/UIns & $\mathrm{Ha} / \mathrm{U}$ \\
\hline Hallux/Carponetacarpus & $\mathrm{Ha} / \mathrm{Gnc}$ \\
\hline
\end{tabular}

In order to doterndine the similarity in trend of the ratios presented in Table 2, the species were assigned numerical rank, besed on the ascending value of a particular ratio. Thus, in considering the ratio Preorbltal widh/Skull Iength, Casmerodius albus, with a mean ratio of 8.43 per cent, occuples position 1 and Cochlearlus cochlearlus, with a mean ratio of 16,75 per cent, occupies position 40. This indicates as far as this particular ratio is concerned, these two species are the most distantly removed from each other. On the other hend, Ardea occidentalls (mean ratio 9.50 per cent) and Ardea herodias (mean ratio 9.64 per cent) occupy positions 6 and 7, raflecting their close relationship. 
Sku17 ratios:

Preorb1tal/Skurn

1. Casmerodius albus

2. Ardes purpures

3. Fydranassa tricolor

4. Ardoe sumatrana

5. Tyrrisome mexdcana

6. Ardea occidentalis

7. Ardes herodias

8. Egretta gargetta

9. Dichromanassa Iufescens

10. Lercophors thuta

11. Ixobrrchus involucris

12. P11herodius pliestus

13. Tigrisoms Iineatum

14. Floridana caerulea

15. Ixobrychus strumil

16. Tigriornis Ieucolopha

17. Ardes gollath

18. Butorides striatus

19. Ardea cinerea

20. Andea cocol

\section{Preorbital/Postorbital:}

1. Corsachitus melanoloohus

2. Nycticorsx caledonicus

3. Nyctanassa violacea

4. Bubulcus 1 bis

5. Syriema sibjiatrix

6. Nycticorax nycticorax

-7. Florlde caerulea

8. TIErisone merceans

9. Pilherodius pileatus

10. Leucophoyx thura

11. Dichromanassa rufescens

12. Tigrisome Iineatum

13. Ardeola spectosa

11. Irobrychus strunts

15. Egretta Earzetta

16. Ardes melanocephala

17. Eerretts intermedia

18. Ardes pactifica

19. Andeola ralloldes

20. Ixcobrychus Involueris

21. Ardeola ralloides

22. Errette intermedia

23. Irobrrychus exdi1s

24. Ardea melanocephale

25. Ardes pseifica

26. Andoola speciosa

27. Bubuleus 1bls

28. Syrigma sibilatrix

29. Butorides virescens

30. Esthocnus rufiventris

31. Botaurus Ientiginosus

32. Ardeola becchus

33. Ircticorax calodonicus

34. Ixobrychus sinens1s

35. Nrctanass violacea

36. Vycticorex mycticorex

37. Botaumis stellaris

38. Corsachi us melanolophus

39. Ixobrychus cinnamomeus

40. Cochlearlus cochlearius
21. Butorides virescens

22. Butorides striatus

23. Erythocnus zufiventris

24. Ardeola bacchus

25. Irobrychus exdI1s

26. Tisriornts leucolophs

27. Cochlearlus cochlearlus

28. Ardes occidentalis

29. Irder herodilas

30. Fydranassa tricolor

31. Ardea poliath

32. Ardes cinerea

33. Casmerodius albus

34. Ardes sumatrana

35. Ixobxychas sinensis

36. Axdes cocos

37. Botaurus Ient1ginosus

38. Botaurus stellaris

39. Ardes purpurea

40. Isobrychus cinnamomeus 
Preorbital/Cranium:

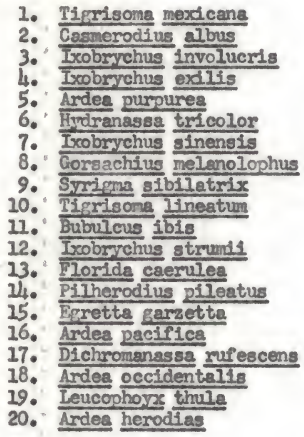

21. Tigriomis leucolophs

22. Butorides virescens

23. Egretts intermedis

24. Ardeola ralloldes

25. Ardea sumatrana

26. Ardoola spec10sa

27. Erythocnus rufiventres

28. Botalures lentiginosus

29. Irctanassa violaces

30. Butorides striatus

31. Brcticorex caledonicus

32. Andea cinerea

33. Botaurus stellaris

34. Andes mel anocephala

35. Ardoola bacchus

36. Axdea gollath

37. Dreticorex nyeticorax

38. Andea cocot

39. Ixobry chus cinnamomeus

40. Cochlearius cochloarius

Postorbital/Cranium:

\begin{tabular}{|c|}
\hline 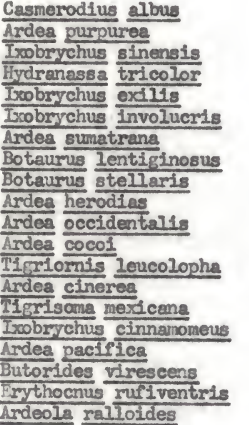 \\
\hline
\end{tabular}

21. Egretta 1ntermedia

22. Ardes goliath

23. Butorides atriatus

24. Irobrychus strumid

25. Tigrisoma 1ineatum

26. Egretta garzetto

27. Ardeola bacchus

28. P17herodins pileatus

29. Dichromanasse rufescens

30. Florlda caeruzea

31. Teucophorx thula

32. Ardea melanocephala

33. Ardeola speciosa

34. Syrigma sibilatrix

35. Bubulcus 1bis

36. Corsachius melanologhus

37. Nyctanassa violacea

38. Nyct1corax nycticorax

39. Nyct1corax calodontcus

40. Cochlearius cochlearius 
Pterygoid/Ouadrate length:

\begin{tabular}{|c|}
\hline 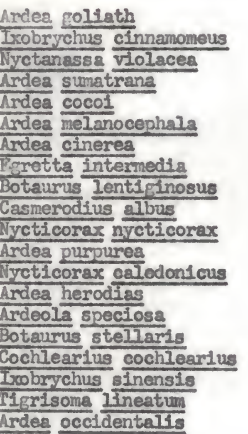 \\
\hline
\end{tabular}

Quadrate width/Quadrate length:

1. Ixobrychus eimanomeus

2. Botsumis stellaris

3. Ardea cocol

4. Ardea occidentelis

5. Ardea cinerea

6. Casmeradius albus

7. Andes herodsas

8. Ardes purpurea

9. Botaurus Ientiginosus

10. Irdea MeIsnocephala

11. Irobrychus involucris

12. Ardea gollath

13. Ixobrychus exdis

14. $\sqrt{y c t i c o r a x}$ nycticorax

15. Ardoa sumatrana

16. Ixobry chus strumil

17. Butorides striatus

18. Ardeola speciosa

19. Tirmormis leucolopha

20. Fretts Intermedia
21. Trobrychus exd11s

22. Gorsachivis melanolophus

23. Erythocnus rufiventris

24. P17herodius pileatus

25. Ardea pacifica

26. Esretta garzetta

27. Ti grisoma nexicana

28. Syrigme sibilotrix

29. Ardeola bacchus

30. ijchromenassa rufescens

31. Bubulcus 1bis

32. Forida carviea

33. Butorides virescens

34. Hydranassa tricolor

35. Butorides striatus

36. Leucophovx thula

37. Irdeole ralloidee

38. Tigriornis leucolopha

39. Leobrychus involueris
21. Exythoonus mufiventris

22. Ardeola bacchus

23. Dyctanasse violacee

24. Nreticorax caledonicus

25. Ardea pacifica

26. Ardeola ralloides

27. Dichromanassa rufescens

28. Leucophorz thule

29. Tigrisoma ineatum

30. Butorides viroscens

31. Floride caerulea

32. Tismisoma mexccana

33. Pilherodius pileatus

34. Euretta carzotta

35. Bubulcus ibis

36. Ixobrychus sinensis

37. Hydranassa tricolor

38. Corsachius Melanolophus

39. Cochlearius cochlearius

40. Syrigma sibilatrix 
Internembral ratios:

Femur/Humerus:
1. Ardea pacifica
2. Ardea cineres
3. Egretta intermedia
4. Ardes herodias
5. Casmerodius albus
6. Syrigma sibilatrix
7. Ardes occidentrils
8. Ardea melanocephala
9. Ardea $\operatorname{coc} 1$
10. DIchromanassa rufescens
11. Leucophorx thula
12. Forida caerulea
13. Erretta Earzette
14. Ardea Bollath
15. Bubuleus ibis
16. Hidranessa tricolor
17. Njetanassa 7101 ces
18. Gorsachtus molanolophus
19. Ardes sumatrana
20. PIIherodius pileatus

21. Nycticorax nycticorax

22. Arden purpures

23. Dreticorex calodontous

24. Ardeola rello1des

25. Irdeola bacchus

26. Ardeols speciosa

27. Exythocmus rufiventris

28. ILerisoma mexicans

29. Butorides virescens

30. Irobrychus strumil

31. Botaurus Ientiginosus

32. Butorides striatus

33. Botaurus stellaris

34. Cochloarius cochloarius

35. TiErisome IIneatum

36. TIErlomts Ieucolopha

37. Irobrychus cinnamomeus

38. Irobrychus sinens 18

39. Ixobrychus exdlis

40. Ixobrychus involuerds

\section{Femur/Unna:}

1. Arder pactelca

2. Egretta intermedia

3. Arder cineres

4. Cosmerodius albus

5. Ardea herodias

6. Syrigma sibilatrix

7. Dichromanassa rulescens

8. Ardee occidentals

9. Ardes Melanocophata

10. Erotte garzetts

11. Leucophory thrula

12. Florda caerulas

13. Trda $\mathrm{Cocol}$

14. Hydranassa tricolor

15. Pilherodius pileatus

16. Ardea sumatrane

17. Bubulcus 1 bis

28. Hyctanesse volacea

19. Gorsachive nelanolophus

20. Ardea gollath

21. Ardea purpurea

22. तrdeole rilloIdes

23. Triderla baccms

24. II IFrisoma mexccana

25. Nycticorax nycticorax

26. Nycticorax calodontcus

27. Cochlearius cochlearius

28. Brythocnus rưfiventris

29. Arder1a speciosa

30. Tigrisom Ineatum

31. Butrordes

32. Butoride striatus

33. Botaurus lentiginosus

34. एxobrychus stmunil

35. Botrurus gtellaris

36. Tigmiomis loucolopha

37. Irobrychus cinnamoineus

38. Ixobrychus exdils

39. Inobrychus InvoIucris 
Femur/Carpometacarpus:

1. Ardee paciflca

2. Syrigma sibilatrix

3. Esretta Intermedia

4. Dichromanassa rufescens

5. Ardea cinerea

6. Casmerodius albus

7. Florda caerulea

8. Ardes herodias

9. Eydranassa tricolor

10. Ieucophoyx thula

11. Firette gersetta

12. Ardea occidentalis

13. Ardea melanocephala

14. PIIherodius plleatus

15. Jyctanassa volaces

16. Gorsachius melanolophus

17. Bubulcus 1bis

18. Andea coco1

19. Ardeola bacchus

20. Ardea rollath

\section{Tibia/thumerus:}

1. Ardeola speciosa

2. Gorsachius melanolophus

3. Nycticorax nycticorax

4. Butorides striatus

5. Frythocnus rufiventris

6. Ardea pacifica

7. Ixobrychus strunil

8. Nycticorax celedonicus

9. Ardeola bacchus

10. Butorides virescens

11. Botaurus stellaris

12. Ardeola ralloides

13. Syrisma sibilatrix

14. Ardes cinerea

15. Botaurus Ientiginosus

16. Ardea occidentals

17. Ardes purpurea

18. Cochlearius cochlearius

19. Ardea gollath

20. Bubulcus 1b1s
21. Nycticorex nycticorax

22. Nreticorax caledonicus

23. Ardeole ralloides

24. Ardea purpuraa

25. Errthocnus rufiventris

26. Irdea sumatrans

27. Botaurus lentiginosus

28. Ardeola specioss

29. Ixobrychus strumil

30. Butorides virescens

31. Tierisoma mexicane

32. Butorides striatus

33. Botaurus stellaris

34. Cochlearius cochlearlus

35. Tigrisome ineatum

36. Irobrychus cinnamomeus

37. Tigriornts leucolopha

38. Ixobrychus sinensis

39. Ixrobrychus exd1is

40. Irobrychus involueris
21. Ardea melanocephara

22. Iyctanassa volacea

23. Tigrisoma mexicana

24. Tigrisoma Tineatum

25. Ardes herodias

26. Tigriornis leucolopha

27. Ixobrychus cinnamomeus

28. Ardea sunatrans

29. Irobrychus sinensis

30. Ardes cocol

31. Fydranassa tricolor

32. P1Iherodius pileatus

33. Ixobrychus exd11s

34. Florids caerules

35. Eeretta intermedts

36. Levicophorx thula

37. Casmerodius albus

38. Dichromanassa mifescens

39. Enretta garzetta

40. Ixobrychus involucris 


\section{Tibla/OIna:}

1. Ardeola speciosa

2. Gorsachius melanolophus

3. Ardea pacifica

4. Syriema sibilatrix

5. Frythoenus rufiventris

6. Ardeole bacchus

7. Ardea cineres

8. Nycticorax nyeticorax

9. Ardeole rallo1des

10. Nycticorax caledonicus

11. Andea occidentalis

12. Butorides Firescens

13. Inobrychus strunit

14. Axdes surnatrana

15. Axdea purpures

16. Tigrisome mexicana

17. Botaurvs stellaris

18. Butroides striatus

19. Bubulcus 1 bis

20. Tigrisoms Iineatum

\section{Tibis/Carporetacarous:}

1. Ardeola speclosa

2. Gorsachius melanolophus

3. Forthocnus rufiventris

4. Ardes pacifica

5. Nycticorax nycticorax

6. Ardeola bacchus

7. Ixobrychus strumis

8. Syrigma sibilatrix

9. Botaurus Ientiginosus

10. Nycticorax caledonicus

11. Butorides striatus

12. Butorides virescens

13. Ardeole ralloides

14. Botaurus stellaris

15. Andes cinerea

26. Iyctanassa Violacea

17. Ixobrychus cinnarnomeus

18. Ardea occidentalis

19. P1lherodius pileatus

20. Ardes purpures
21. Ardea melanocephala

22. Irdes herodias

23. Cochlearius cochlearius

24. Botsurus Ientiginosus

25. Pllherodius plleatus

26. Vyctansssa violacen

27. I1 griornis leucolophe

28. Ardes gollath

29. Hydranassa tricolor

30. Andea c0001

31. Frretts intermedia

32. Leucophoyx thura

33. Casmerodius albus

34. Dichromansssa zufescens

35. Florida caerules

36. Irobrychus cinnemoneus

37. Esretta garzetta

38. Iscobrychus involucris

39. Irobrychus exilis

21. Bubrulcus 1b1s

22. T1grsom Ineatur

23. Migrisoma nexicana

24. Hydranesse tricolor

25. Ardea herodias

26. Cochlearius cochlearius

27. Florida carules

28. Dichromanassa Infescens

29. Ardes melanocephala

30. Leucophove thula

31. Irobrychus sinensis

32. Ardea goliath

33. E[retta intermedia

34. Tigriornis leucolopha

35. Egretta garzetta

36. Irdes sumatrens

37. Casmerodius albus

38. Ixobrychus exi11s

39. Ardea coco1

40. Irobrychus involucris 


\section{Tarsus/Humerus:}

1. Ixobrychus strumis

2. Nycticorax nycticorax

3. Frythocrus mufiventris

4. Butorides striatus

5. Gorsachtus melanolophus

6. Botaurue stollaris

7. Ardeola becchus

8. Nycticorex caledonteus

9. Butorides viroscens

20. Ardeole rello1des

11. Ardeola speciose

12. Botaurus lentiginosus

13. Irobrychus cinnamomeus

14. Cochlearius cochlearius

15. Tieriomis leucolophs

16. Syrigma sibilatrix

17. Arden pactifics

18. Ireobrychus involucrls

19. Ixobrychus sinensis

20. Ardea cinerea
21. Tierisome mexdcana

22. Ardea purpures

23. Ixobrychus exdits

21. Bubutous $1 \mathrm{~b}$ is

25. Ardea Bolisth

26. Ardea sunatrana

27. T1हलrisore lineatum

28. Ardes occidentalis

29. Ardea melanocephala

30. Vyctanassa violaces

31. Andea herodias

32. Pilherodius pileatus

33. Egretta garzetts

34. Ardea cocol

35. Mlorida caerulea

36. Leucophoyx thula

37. Fydranassa tricolor

38. Erretts intermedis

39. Casmerodius albus

40. Dichromanasse mufescens

\section{Tarsus/U1na:}

1. Gorsachlus melanolophus

2. Andeola bacchus

3. Erythoenus mufiventris

4. Nycticor $2 x$ nycticorex

5. Irobrychus strumis

6. Ardeols rello1des

7. Butorides striatus

8. Botaums stellams

9. Butorides virescens

10. Nycticorax celedonicus

11. Ardeole speciose

12. Syrigma sibilatrix

13. Cochlearius cochlearius

14. Theriornis 1eucolophs

15. Ardea sumatrana

16. Ardea pacifica

17. Tigrisoma mexcana

18. Botsurus lenticinosus

19. Ardea cinerea

20. Ardes purpurea
21. Ixobrychus cinnamomeus

22. Bubuicus ibIs

23. Tiorisoms Tinoatum

21. Ardea gollath

25. P17herodius pileatus

26. Ardos melanocephala

27. Ariee occidentalis

28. Ardea herodsos

29. Vyctanasse violacea

30. Irobrychus Involucris

31. Ecretta garsetta

32. Trobbrychus exdils

33. Leucophoyx thula

34. Ecrotts intermedia

35. Florida caerulea

36. Ardea coco1

37. Hydranasse tricolor

38. Casmerodius albus

39. Dichromanassa mufescens 
Tarsug/Carpometacarpus:

1. Irobrychus strunil

2. Exythocnus mifiventris

3. Ardeola bacchus

4. Nycticorex nveticorax

5. Corsachius melanolophus

6. Botaurus stellaris

7. Butorides striatus

8. Ardeola ralloldes

9. Nycticorax caledonicus

10. Butorides virescens

11. Botaurus 1ent1ginosus

12. Ixobrychus cinnamomeus

13. Ardeols speciosa

14. Svrigma sibilatrix

15. Ardea pactica

16. Cochlearius cochlearius

17. Tigrisome nexicana

18. Ardee cineres

19. Ardea purpurea

20. TIEriornis Ieucolophs
21. Nyctanassa yLolaces

22. Bubulcus 1 bis

23. Ixobrychus sinensis

24. Ixobrychus Involueris

25. T1Frisoma 1 Ineatur

26. P1Iherodius p11eatus

27. Ixobrychus exd11s

28. Ardea occidentalis

29. Fydranasse tricolor

30. Andes herodias

31. Florida ceerviea

32. Ardes melenocephala

33. Ardea golisth

34. Frrett sarzetta

35. Ardea surutrana

36. Ieucophoys thuls

37. Erretta intermedia

38. DIchromanassa rufescens

39. Casmerod1us albus

40. Ardes cocol
Hallux/Humerus:

1. Ardea cinerea

2. Nyctanasse violacea

3. Ardea melanocephala

4. Gorsachius melanolophus

5. Ardea herodias

6. Dichromanassa mufeacens

7. Ardes pacifica

8. Ardea occidentalis

9. Ardea cocol

10. Nyct1corax nyct1corax

11. Casmerodius albus

12. Nrcticorax caledontcus

13. Egratta sarzetta

14. Leucophorx thula

15. Cochlearius cochlearius

16. Syriems sib1 Iatrix

17. Erythocnus rufiventris

18. Ardea sumatrana

19. Ardes gollath

20. Botaurus stellaris
21. Tlgrisoma Iineatura

22. I1 rrisoma mexlcana

23. Ardeols becchus

24. Iydranassa tricolor

25. Ardeola rello1des

26. Florlda caerules

27. Eeretta interned1s

28. Bubulous 1bis

29. Tleriornis Teucolopha

30. P11herodius pileatus

31. Butorides striatus

32. Ixobrychus strund?

33. Ardeola speciosa

34. Butorides virescens

35. Botaurus 1entiginosus

36. Ardea purpurea

37. Ixobry chus cinnariomeus

38. Iroobrychus sinensis

39. Ixpbrychus involucria

40. Ixobrychus exdis 
Hallux/Ulna:

1. Ardea cinerea

2. Dichromanassa rufescens

3. Ardea melanocephals

4. Nyctanassa violacea

5. Gorsach1us melonolophus

6. Ardea herodias

7. Ardea pacifica

8. Ardea occidental1s

-9. Casmerodius albus

10. Ardea cocol

11. Egretta garzetts

12. Ardes sumatrana

13. Leucophoys thula

14. PIherodius plleatus

15. Syrigme sibilatrix

16. Nycticorax nxcticorax

17. TIErisoma Ineatum

18. Nret1corax caledontcus

19. Cochlearius cochlearius

20. T1prisoma nexicans

\section{HeIlux/Carpomotacarous:}

1. Ardea cinerea

2. D1chromanassa rufescens

3. Nrctanassa violecea

4. Corsachtus melanolophus

5. Ardea pacifica

6. Ardea herodias

7. Ardea melanocephala

8. Ardes occidentaris

9. Iyct1 corax caledonicus

10. Syrima sibilatris

11. Ircticorax nycticorax

12. Erretta farzetta

13. Casmerodius albus

14. Leucophorx thula

15. Erythocnus rufiventris

16. Andeola bacchus

17. Hydranassa tricolor

18. Ardes coco1

19. P1Lerodius pileatus

20. Florida caerulea
21. Hrdranasse trlcolor

22.' Frretta intermedis

23. Errthocnus rufiventris

24. Indeola bacchus

25. Ardea goWath

26. Frorida caerviea

27. Ardeola rallotdes

28. Bubulcus 1 bis

29. Mgrlornts Ieucolophe

30. Botaurus stellaris

31. Andeola speciosa

32. Butorides virescens

33. Butorides stratus

34. Ixobrychus strumi1

35. Ardea purouroa

36. Botaurug Ientiginogus

37. Ixobrrchus cinnamomeus

38. Ixpbrychus sinensis

39. Ixobrychus exilis
21. Botaurus stellaris

22. Tigrisome Ineatun

23. Ardeols ralloides

24: Cochlearlus cochlearlus

25. Tifrisome mexicana

26. IIgriormis leucolopha

27. Egrette Internedis

28. Ixobrychus strunti

29. Ardes sumatrana

30. Bubulcus 1bis

31. Ardea goliath

32. Botaurus Ientiglnosus

33. Butorides virescens

34. Butorides gtriatus

35. Irdeola speciosa

36. Irobrychus cinnamomeus

37. Ardea purrourea

38. Ixobrychus sinensis

39. Ixobrychus Involucris

40. Ixobrychus exclis 
Intranembrel Ratios:

Fumervs/U1na:

1. P1Iherodius pileatus

2. Ardea sumatrana

3. Bgretts garzetts

4. Dichromenasse mifescens

5. Erretta intermedia

6. Leucophorx thule

7. Casmerodíns albus

8. Syrigms s1bilatrix

9. Tigmisome lineatum

10. Tigrisoma mexdcana

11. Fydranasse tricolor

12. Ardea pacifica

13. Ardea herodias

14. Florida crerules

15. Andea coco1

16. Ardea cinerea

17. Andea melanocephals

18. Ardes gollath

19. Gorsachtus molanolophus

20. Nyctanassa v10lacea

Radius/Une:

1. Ardea sumatrana

2. Ixobrychus cinnamomeus

3. Tigriomis Ieucolopha

4. Ardeola speciosa

5. Cochlearius cochlearius

6. Ardeola becchus

7. Tierisoma IIneatum

8. Ixobrychis axdis

9. Ardea cocoi

10. TIgrisoma mexdcana

11. Ardeola ralloides

12. Exythoenus rufiventris

13. Ixobrychus struml1

4. Botaurus Ientiginosus

15. Pliherodsus pileatus

16. Butorides virescens

17. Botaurus stellaris

18. Nyct1corer caledonicus

19. Ardea gollath

20. Butorldes striatus

21. Ardeols bacchus

22. Ardea occidentris

23. Ardes purpurea

24. Tigriorn's Ieucolopha

25. Bubulcus Ibis

26. Cochloarius cochlearius

27. Ardeols r2710ides

28. Ersthocmus rufiventris

29. Andeola speciosa

30. Butordes Virescens

31. Nycticorax nycticorex

32. vycticorax caledontcus

33. Butorides striatus

34. Botaurus lentiginosus

35. Botaurus stellaris

36. Ixobrychus strumif

37. Irobryychus cinnamomeus

38. Ixobrychas Involucris

39. Irobrychus exd11s
21. Nyctanassa violacea

-22. Nycticorax nycticorax

23. डyz-1gma s1bilatrix

24. Ixobrychus involucris

25. Egretta sarzetta

26. Florida caerulea

27. Ardes purroures

28. Bubuleus 1bis

29. Casmerodsus albus

30. Eeretta intersinedia

31. Leucophoyx thule

32. Andea pacifice

33. Ardes occidentars

34. Gorsachius melanolophus

35. Dichromanassa mufescens

36. Andes herodias

37. Ardea cinerea

38. Ardes melanocephals

39. Fydranassa tricolor 
Carpometacarpus/UIng:

1. Ardea oumatrana

2. Ardes goliath

3. Andea cocos

4. Ardea melanocephala

5. Tisflornis leucolophe

6. Casmerodius albus

7. Ardea herodias

8. Cochlearius cochlearius

9. Tirrsoma mexcana

10. Ardea occidentalts

11. Ardea cinerea

12. Timisoine Ineatum

13. Sipretta intermedis

14. Bubulcus 1b1s

15. Egretta Earzetts

16. Ardea purpuree

17. P17herodius pileatus

18. Ieucophoyx thurs

19. Gorsechius melenolophus

20. Ivetanassa violacea

\section{Digit 2, Phalanx 1/UIna:}

1. Ardea sumatrana

2. Ardea melanocephala

3. Tigriscine Iineatum

4. Casmerodius albus

5. Tigrisome mexicana

6. Ardes occidentaris

7. Ardea cocol

8. Epretta intermedia

9. Tigriornis Ievcolophs

10. Ardea herodias

11. Ardea cInerea

12. Dichromanasas mufescens

23. Botaurus stellaris

14. Ievcophoyx thula

15. Ardea purpurea

16. Andes gollath

17. Corsachíus melanolophus

18. P17herodius pileatus

19. Ardeols bacchus

20. Ixobrychus ext11s
21. Ardeola ralloldea

22. Ardes paciflce

23. Dichromanassa rufescens

21. Ardeola speciose

25. Svrigma sibilatrix

- 26. Mlorida caerulea

- 27. Hudranasse tricolor

28. Butorides striatus

29. Butordes virescens

30. Irobrychus involucris

31. Nycticorax caledonicus

32. Nxet1corax nycticorax

33. Ardeola bacchus

34. Botaurus stellaris

35. Erythocnus Iufiventris

36. Ixobrychus exil1s

37. Ixobrychus strunt1

38. Botaurus Ientiginosus

39. Ixobrychus cinnomomeus
21. Ardeola ralloldes

22. Butorides virescens

23. Frythocmus rufiventirls

24. Egretta Eerzetta

25. Cochlearius oochlearlus

26. Botaurus Iont1EInosus

27. Andeola speciosa

28. Nyctanassa violocea

29. Bubulcus Ibis

30. Arden pecifica

31. Sycina sibilatrix

32. Iycticorex caledonteus

33. Irobrychus cinnamomeus

34. Dutorides striatus

35. Frdranassa tricolor

36. Nycticorax nycticorex

37. Florda caerules

38. Ispbrychus strumls

39. Ixobryclins involucris 


\section{Timriornis leucolopha \\ 2. Ardes sumatrans \\ 3. Tigrisoma ijneatum \\ 4. Florida caerviles \\ 5. Ardes goliath \\ 6. Ardes purpures \\ - 7. Hydranassa tricolor \\ 8. Gorsachius melanolophus \\ 9. Irdea herodias \\ 10. Tigrisome mexcicans \\ 11. Ardies cíneres \\ 12. Ardea mclanocephala \\ 13. Casmerodius albus \\ I4. Botaume steliaris \\ 15. Ardes occidentars \\ 16. Dichromenassa zufescens \\ 17. Egretta intermedis \\ 18. Botaurus Ientiginosus \\ 19. Arden coco 1 \\ 20. Pilherodius pileatus}

\section{Fenur/ribie:}

1. Erretta internedis

2. Casmerodius albus

3. Dichromanassa zuf escens

4. Egrette garzetta

5. Leucophoyx thurte

-6. Forida caerule

7. Ardea herodias

8. Axden cccol

-9. Hydranassa trlcolor

10. Ardea pecifica

11. Ardea melanocerhala

12. Ardes cineres

13. Ardes occidentalis

14. Symigne sibilatrix

15. Pilherodius pileatus

16. Andea coliath

-17. Bubuicus 1b1s

18. Ardea sumatrana

19. Vycianas violaces

20. hirdes purvurea
21. Nyctanassa v1olecea

22. Syrigma sibilatrix

23. Cochlearius cochlearius

24. Leucopharx thula

25. Iycticorax caledonicus

26. Ardea pecifica

27. Butorides striatus

28. Nycticorax nycticorax

29. Butorides virescens

30. Ixrobrychus exdilis

31. Ireobrychus cinnamiomeus

32. Exthocrus ruf'iventris

33. Ardeols ranloides

34. Feretta araretta

35. Ixobrychus involucris

36. Bubrilcus ibis

37. Irobreychus strumil

38. Ardeola bacchus

39. Ardools speciose
21. Corsachius melenolophus

22. Tigrisorre ineatum

23. Ticrisorra mertcens

24. Cochlearlus cochlearius

25. Ardeols remoides

26. Nycticorex caledonicus

27. Ardeols bacchus

-28. Vycticorax nycticorex

29. Butorides virescens

30. Botaurus lentipinosus

31. Erythocnus rufiventris

32. Botaurus stellaris

33. Butorides striatus

34. Pleriornis leucolophe

35. Irobrychus cinnamomeus

36. Ixobbrychus exd14:

37. Ixobrychus Binensis

38. Irobrychus involucris

39. Ixobrychus strumis

40. Andoola speciosa 
Tarsonetatarsus/T1blotarsus:

1. Botaurus stellaris

2. Ixobrychus strundi

3. Ixobrychus Involucrls

4. Isobrychus cinnanomeus

5. Ixobrrchus exilis

6. Erythocnus rufiventris

7. Ardeola bacchus

8. Ardcola ralloides

9. Butorides striatus

10. Butorides virescens

11. Sycticorax nycticorax

12. Nycticorax caledontcus

13. T1Erlornis leucolophs

14. Cochlearius cochlearius

15. Irobrychus sinensis

16. Gorsachius melanolophns

17. Botaurus Ient1 inasus

18. Indea sumatrana

19. Eretta sarzetta

20. Fisrisoma mexcans

21. Andee gollath

22. Bubuicus 1b10

23. Ardea purpurea

24. Timrisoma 1ineatum

25. Syrigne s1bilatrix

26. Morida caerviea

27. PIIherodius p1leatus

28. Nyctanasse violacen

29. Ardea melenocephals

30. Leucophoyx thula

32. Frretts intermedia

32. Ardes herodies

33. Ardea cocol

34. Andea cineres

35. Casmerodius albus

36. Iydranassa tricolor

37. Ardea occidentalis

38. Ardea pacticica

39. Jichromanasse rufescens

40. Ardeols speciosa

\section{Manux/Tiblotersus}

1. Dichronenass rufescens

2. Cesmerodiug 2lbus

3. Ardea cinerea

4. Nrctanassa volacea

5. Ardas melanoleohata

6. Ardea herodias

7. Exretts sarzetts

8. Irdea cocol

9. Ieucophoxx thuia

10. Ardea occidentalis

11. Irdes pacifice

12. Erretta intermedia

13. Flosida caerviea

14. Fudranesse tricolor

15. Cochlearius cochtearlus

16. Gorsachius melanotophus

17. Ardea sumatrana

18. P1Therodius pileatus

19. Ardea gollath

20. IIfrisome IInestum

21. T1erisoms mexclcena

22. Nycticorax coledonicus

23. Tinglornis leucolopha

24. Nycticorax nycticorex

25. Syrign sibilatrix

-26. Bubulcus 1bis

27. Botaurus Btellaris

28. Andeola bacchus

29. Ardeole relloldes

30. Erythocnus rufiventris

31. Ixobyychus Involucris

32. Irobrychus cinnamomeus

33. Butorides virescens

34. Ixobrychus extis

35. Ardes purpures

36. Butorides strlatua

37. Irobrychus sinensis

38. Botaums Ientisinosus

39. Irobrychus strumil

40. Arceole apeciose 


\section{QUALTTATIVS CHARACTERS}

Those physicel characters not lending thenselves readily to measurement were compared before Pinal analyses of the statistical date were made.

Internagal sentum. Although Shufeldt (1889a, 1889b, 1901) states that the internasal septum is very incomplete or altogether missing in the subfauliy Axdeinae, ay investigations indicate that the condition of the nares is sufficient to divide the representative forms of the fandly Ardeldee Into two well defined groups, with a third group heving internediate condition.

In one extreme condition, the nares are completely divided into two well definod passages by a thin sheet of osseous material extending diagonally from the antero-dorsal to the posteromventral angles of the nares. The forms showing this condition are as follows: P1Iherodius

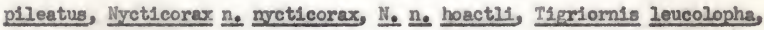
and T1erisoma mexdcena.

The other extrene is represented by the condition in which there is no septum. This condition occurs in Andes sumatrens, $\Lambda_{0}$ gollath, $A_{0}$ melanocephals, A. herodias treganzai, A. ho herodias, A. occidentalis, A. pactelca, A. purourea, Butorides vo virescens, B. striatus, 1rdeola rallojdes, 1. bacchus, A. spectosa, Dichromanassa rufescens, and flydranasse tricolor.

An intermediate condition exdsts in which there is a amall projection of bone from the dorso-medial surface of the nares. This is present in the following forms: Florida caerules, Casmerodius albus 


\section{4}

egretta, C. a. modestus, Egretta intermedia, Leucophoyx thula, Syrigma sibllatrix, Nycticorex celedonicus, Nyctanassa vo violacea, No vo bencrofti, Gorsachius melanolophus, Tigrisoma Iineatum, Ixobsychus sinensis, I. involucris, I. exd11s, I. cinnamomeus, I. strumi1, Botaurus stellaris, and B. lentiginosus.

Supreorbital racuitios. These are a pair of greatly entarged foremina which Shufelat (1889a) termed the olfactory foramina. They lie on the anteromventral angle of the brain case immediately above the orbits and on either side of the interorbital septum. Variations in the shape and structure of these facuities make it possible to separate the members of the fandly into several groups.

The extreme conditions occur in the genus Andea. The vacuities are of average sise in all forms except ‥ golliath and A. pacifica, the largest and smallest forms, respectively, of the genus. In $\Lambda_{0}$ pacifics the peired vacuities are greatly enlarged, exposing fully hale of the ventral surface of the brain. The opposite condition occurs in $\Lambda_{0}$ goliath. In this form these openings are greatly reduced and are only large enough for the passage of a small nerve,

A modification in the shape of these vaculties makes 1t possible to separate two genera, 1. 0. Nycticorex and T1griornis, from the rematnder of the fandiy. In these genera each vaculty is divided by a amall bong profection extending posteromdorsally from the medial septum, thus producing four greatly reduced openings. Nycticorax caledonicus shows the greatest modification with the partition being much broadened. The partition is also present in Nycticorax $\mathrm{n}_{\text {. nycticorax }}$ and $\mathrm{N}_{0} \mathrm{n}_{0}$ hoactlis in 
varying degrees, some specimens having a complete partition, others havw ing an incomplete partition.

The supraorbital vacuities are absent in Tigrisoma lineatum, I.

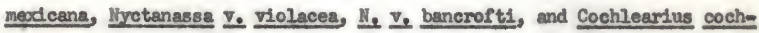
1earius.

Fetethmo1d: The ethmold as described by Shufeldt (1889a, 1889b, 1901) is a composite bone bearing a pair of opposing lateral extensions which are here reforred to as the ectethmo1ds. Each of these is divisible Into a superior and inferior process. The superior process is in intimate contact with the superior process of the lacrimal and lies just posterior to the eranioufacial hinge. The inferior process is a flattened, truncate projection extending laterally and ventrally from the base of the ethnoid.

On the basis of the contour and conformation of the ectethmoid, members of the fanily Ardeidae nay be divided into three definite groups; one showing a separation and reduction of the superior and inferior processes, another with both portions of normal size and connected by a bony bridge, the thind being characterised by the loss of the bridge and complete reduction of the inferior process.

The following forms fall into the first category: Dichronanassa rufescens, Casmerodius albus egrotta, c. ‥ nodestus, Erretta garzetta garzetta, E. ge nieripes, Hydranassa tricolor, Butorides Vo virescens, B. striatus, Foride caerules Andeola ralloides, 스 bacehus, As specioss, Bubuleus 1bis, Leucophorx thula Nyctanassa vo vlolaces, … V. bancrofti, Gorsachius melanolophus, Tierisoma 21neatum, I. mexicans, Botaurus 
stellaris, Bo lentiginosus, Irobrychus sinensis, In involucris, I. exdiss, I. cinnamomeus, and I. strmm1s.

Group two, in which both portions are of normal alse and connected by a bony bridge, is best exemplified by the genus Nycticorex. In this genus the superior process extends dorsally and is in intimate contact with the dorso-medial portion of the lecrimal. The inferior process is elongate and flattened, and is in contret with the gygomatic process of the lacrimal. The tap portions of the ectethnoid are comnected by a delicete bony bridge. A deep groove lies beneath the ectethinold bridge passing anteriorly from the supraorbital foramina. Anterior to the bridge the groove passes into a number of minute ramifications, and disappears near the posterfor margin of the ethmoid bone. This condition is characterlstic of Nycticorax $\underline{n}_{0}$ nycticorax, N. ․ no hoctis, № caledonicus,

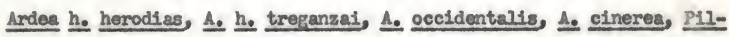
herodius pileatus, and Syrigus sibilatrix.

The third condition is one of complete reduction, or absence of the Inferior process and the comnecting bridge. This condition is characteristic of Tigriornis Leucolopha and Cochlearius cochlearius.

Lecrimal: The lacrimal is a highly pneuratic bone which fills the space between the frontal, orbitosphenoid, and ethmoid, and always forns the anterior part of the orb1t (Newton, 1896). In the Ardeidae $1 t$ articulste with frontal and nasal bones dorsally, and shows considarable varlation in the confornation of the ventral or inferior process. The rariation of the inferior process is of some value in indicating rolationships within the fanily. 
In the following discussion the portion articulating with the nasal, frontal and orbitosphenoid will be referred to as the superior process, while the postero-ventral projection will be referred to as the Inferlor process, Within the fanily there are two basic designs, each showing charecteristic modifications which may be correlated with nodifications previously discusaed under the ectethmold. The first is the type conmon to the gemus Ardea with greatly enlarged inferior and superior proceases. The inferior process $110 \mathrm{~s}$ in a plane parallel with the zygoma and is grooved ventrally to receive the zygoma. A medial extension of the inferior process attaches by 11gaments to the ectethmoid. These two connections, to the sygome and the ectethmoid, lend added strength to the skull and prevent excessive flexing of the culmen at the level of the cranio-facial hinge. This type lacrinal is common to

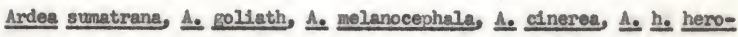
dias, … ho tregansal, A. occidentalis, 스 coco1, A. purpoures, Casmerodius albus egretta, c. ‥ modestus, Tigrisoma I1neatum and T. mexicana.

The second basic type exhibits a much reduced inferlor process projecting diagonally in a postero-ventral direction. These may be further divided into two groups, one with the ventral border of the inferior process notched, the other with this surface entire. In neither group is the inferior process in contact with the eygoma or the ectethnoid. The following forms fall into the first sub-groups Butorldes 前 virescens, B. striatus, Morida caerulea, Ardeola speciosa, 스 bacchus, A. ralloldes, Bubuleus ibis, Dichromanassa rufescens, Feretts g. gargetta, E. E. nigripes, E. intermedia, Leucophorx thula, Hydranassa tricolor, Syrigne 
sibilatrix, Nyctanassa $v_{0}$ Violscee, № vo bancroft1, Gorsachius melanolophus, Botaurus lentiginosus, B. stellarls, Ixobrychis sinensis, I. involucris, In exilis, In elnnamomeus, and I. strumis. The second sub-group includes only the following forms: Nycticorax $\underline{n}_{0}$ nyet1corax, … no hoactli, and 1 . caledonicus.

The condition of the notch in the first sub-group shows considerw able variation. It is most evident in Dichromanassa, Casmerodius, Bgretta, and Fydranesse. The notch is slight but still evident in Butorides, Florida, Ardeola, Bubulaus, and Leucophorx. Another projection is also evident on the inferior process in Casmerodius albus and Egretta alba. This projection extends enteriorly from the bese of the inferior process, giving the lacrimal the generalized appearance of an "I", w1th the base forving an acute angle with the sygoma. This additional process gives the lacrimal of these two forms a diagnostic character not evident in the renainder of the herons.

The asymmetrical condition of the inferior process in sub-group one is evident in the expansion of the medial projection of the notched distal and. This expansion apperently conpensates for the reduction of the inferior process of the ectethmoid, and nay be directly correlated vith this reduction.

A sculptured condition of the lateral surface of the lacrimal is evident in three genere, namely, Andes, Tigriomis, and Tierisoms. The lacrimel of Axdes, while only gently seulptured, shows a trend toward the formation of a canal acroes the lateral proxinal portion of the inforior process. In Tigriornis and Timigoma the extremo condition is a 
deep notch almost completely surrounded by bone. The purpose of this canal or notch is not lenown.

In addition to the above mentioned differences a medial protuberance is present on the aygome of Ardes, Trgriornis and T1Erisoma at the point of articulation with the lacrimal. This protuberance gives edditional strength to the bony conplex supporting the anterlor part of the cranium and the base of the culmen in the larger, more robust forms of the frmily Ardeldae.

Furculum: The structure of the hypocleddiun of the furculum is sufficiently distinet to divide the representatives of the fandiy into five distinct groups. Groups one and two are characterized by the condition of the inferior process, 1. e., truncate, or short and notched. Groups three and four are characterized by the condition of the superior process, 1.0., spetulate, or short and pointed. The absence of both the inferior and superior process is the criterion for group five.

Group one exhibits the truncate inferior process and includes the following forms: Ardea cocol, A. sumatrana, 스 ho herodias, A. melano-

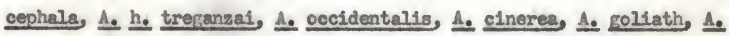
puroures, A. pacifics, Butorides v. Virescens, B. striatus, Florids caerulea, Ardeola ralloides, A. bacchus, A. speciosa, Bubulcus 1bis,

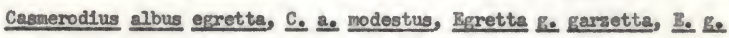
nieripes, E. internedis, Leucophoyx thula, Hydranassa tricolor, Nyctanassa V. Violacea, and N. Vo bancrefti.

Group two exchibits the short notched inferior process which is characteristic of the following forms: P1Iherodius plleatus, Erythocnus 
rufiventris, Dichromanassa rufescens, Sycigma sibilatrix, Nyct1corax n. nyct1corex, N. n. hoactli, N. caledonicus, Corsachius melanolophus, Ixobrychus sinensis, I. Involucris, I. exil1s, I. cinnanomeus, I. strudi, Botaums stollaris, and B. Ient1ginosus.

Group three exhibits the spatulate superior process of the hypocleidium which is characteristic of the following forms: Ardea cocol, A. h. herodias, A. h. tregansai, A. occldentalis, A. cinerea, A. goliath, Pilherodius plleatus, Florlda caerulea, Dichromanassa rufescens, Casmero-

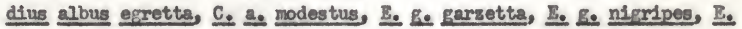
Internedis, Ieudophorx thuia, Hydranassa trloolor, Nycticorax n. nyet1corax, N. n. hoactli, N. caledonicus, Nrctanassa vo violaces, ‥ Vo bencroft1, and Corsachius melanolophus.

Group four exhibits the short, pointed superior process of the hypocleidiun whlch is characteriatic of the following forms: Ardea paciflcs, A. purpures, Butorldes vo virescens, B. Btriatus, Ardeola rallo1des, A. bacchus, A. spec1ose, Bubulcus 1bis, Syrigma sibilatrix, Ixobrychus sinensis, I. involucris, Io exdils, I. cinnamomeus, I. strunil, Botaurus stellaris, and B. Ientiglnosus.

Group flve exchibits a unique condition of the furculum in which both the inferior and superior processes of the hypocloldiun are absent. The apex of the furculum forms a smooth rounded surface for articulation with the carina. This group includes T1griornis Leucolophe, I1grisome IIneatum, and I. mexicana.

Further Investigations showed that the truncste inferior process may be in combination with el ther of the variations of the inferior 
32

process. Inkevise, the short notehed inferior process mey be in combination with either type of superior process. On this besis the followIng groups were observed:

Group I is exemplified by the truncate inferior, and the spatulate superior processes. This group includes the following forms: Ardea

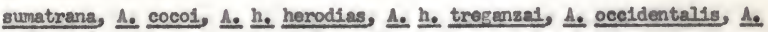
cinerea, A. melanocephals, 스 goliath, Plorida caerulas, Casmerodius albus

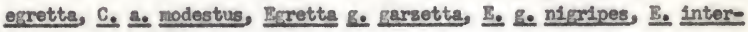
media, Leucophoyx thula, Hydrenassa tricolor, Nyctanasse vo violeces, and N. Vo bancrofti.

Group II combines the truncate Inferior process with the short pointed superfor process and Includes the following forms: Ardes pur:purea, 1. pacifica, Butorides Vo virescens, B. striatus, Ardeola relloides, A. bacchus, A, speciose, and Bubuleus ibis.

Group III combines the short, notched inferior process with the spatulate superior process and Includes the following forms: P17hero= dive plleatus, Dichromanassa rufescens, Nycticorax $\underline{n}_{0}$ nyeticorax, 프. hoactli, N. caledonicus, Gorsachius melanolophus, and Cochlearius cochlearius.

Group IV combines the short, notched Inferlor process with the short, pointed superior process and is restricted to the subfanily Botaurinae. The following forms were found to belong to this grougs Frythocnus rufiventris, Syrigas sibilatrix, Ixobrychus sinensis, I. Involueris, I. exdi1s, I. cinnemomeus, Io strunds, Botaurus stellaris, and B. Lentiginosus. 
An exsaination of the carinae of the various forms was made and shows that the condition of the anterior artieular surface may be predicted If the condition of the furculum is lenown. Those forms possessIng a truncate inferlor process of the hypocleldiun invariably show a broad, Plattened articular surface of the carina. Forns in which the Inferior process is absent, or is short and notched, articulate with a sharply pointed anterior surface of the carina.

These latter combinations of the conditions of the hypoeleidiun (Groups I - IV) show a aore definite grouping within the fanily than do the former. It.will be noted that Groups I and II Include the najority of the true-herons, and Indicate a possible trend from Group I to Group II through Andea purpourea and 1. pacif1ca. Groups III and IV Include all bitterns and night herons, with the exception of the gemus livetanassa.

Coraco1d: Newton (1896) states that the correoid is one of the most characteristio bones of the ornithie skeleton, and that the condstion of the procoracold is of tasonomie value in higher categories.

Fxand nation of the procoracold of herons shows that this process 1s quite similar throughout the family thus making it useless as a dingnostic character on the generlc level.

Iscamination of the proxdmal end of the coracosd showed sufficient difference to warrent separation of two genera, 1.e., Casmerodius and Egretta, from the remeinder of the herons. In both genera the sternal facet is greatly reduced in lateral extent, and is restricted to the extreme medial margin of the coracoid. In other herons the stemal facet is discernible across the entire base of the coracoid, but becones 
progressively smaller toward the laterel border. Forms possessing the mall sized, medially placed sternal facet Include Cesmerodius albus

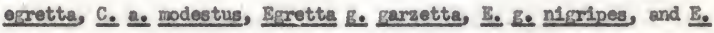
intermedis. In these forms there is also a noticeable modification of the sterno-coracoidal Impression which correlates closely with the condition of the sternal facet. This ingression extends neariy or quite to the proximal border of the coracold, but ends abruptly at the 1 ine of the sternal facet in all other herons.

The position of the intranuscular line on the ventral surface of the coracold serves as a character for separating the herons into two groups. In one group the intramuscular line between $\mathrm{K}_{\text {. suprocoracoldeus }}$

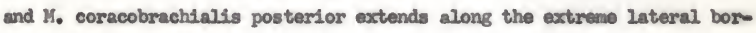
der for the entire length of the corrcoid. Forms possessing this character are as follows: Tigriornis leucolopha, Tigrisoma mexdcans, T. Ineatur, Botaurus stellaris, B. lentiginosus, Ixobrychus exdl1s, and Cochlearius cochlearius. In other forms exandned the intramuscular in varies from centrel to medial in position.

Carpometacarpos: A gross examination of this element indicates a close relationship of all forms ourrently assigned to this fanlly. The condition of the tendinal groove, however, makes it possible to separate the herons into two groups. In the firat group a deep tendinal groove is present and is charecteristic of the following: Ardea poliath, A. h. herodias, A. occidentalis, $\Lambda_{0}$ cineres, $\Lambda_{0}$ purourea, 스 pacifics,

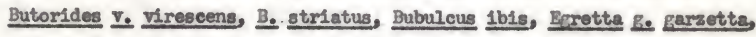
E. I. nilgripes, E. intermedia, Leucophoyx thula, Hydranassa tricolor, 
Nycticorax no hoactil, No caledonicus, Corsachivs melanolophus, IIerior= nis leucolophs, 119risona 11neatum, T. mexicana, Botaurus stellaris, and B. Ientiginosus. In other forms exconined the tendinal groove is wuch reduced, and is barely discernible in some.

One additional character was noted. This is the condition of the anterlor carpal fossa in the genus Ifigrisoma. This fossa is considerably onlarged in area and depth, and is characteristic of both Tiarisome lineeturn and T. mexicans. The condition of this fossa shows only a amall. amount of variation in the tiger bitterns at mo disposal and may possibly be considered a generic character for that group. This fossa is greatiy reduced In area and depth in all other herons examined. Tibia-fibula: Shufeldt (1889a, 1889b, 1901) states that the Pibula of Nyctanassa is ankylosed to the tibia at 1ts distal and. Wetnore (1918) states further that ankylosis of the ribula and the tibia occur in the herons only in Nyctanasse.

A critical exanination of the forms at 10 disposal indieates that such ankylosis occur in the following forms: Ardea cineres, A. gollath, Bubulcus 1bis, Cesmerodius albus egretta, c. a. modestus, Esrette Intermedia, Nrcticorax caledonicus, Nyctanassa vo violaces, № vo bancrofti, and Goraschius melanolophus.

Tarsometatarsus: The condition of the proxinal end of the tarsometatarsus, the hypotarsus, is such that the representative of the fandiy Ardeldae may be divided Into four groups, two apparently forming the pattern for the fanily, two others being off-shoots of the basic plan. 
These groups are besed on the number of complete tendinal cenals present in the hypotarsus.

The nembers of Group I have a single complete canal, flanked on two sldes, 1.e.: above and to one side, by an incouplete canal. Forras showing this condition are as follows: Ardea gollath, Af cineres, Ac $_{0}$ herodias, A. occidentalis, Butorides yo virescens, Bo striatus, Casmero= dius albus egretta, Brrette ge garzetts, Lovicophorx thula, Hydranasse tricolor, Syrigme sibilatrix, vixcticorax $\mathrm{n}_{\circ}$ nycticorax, N. … hoactis, Nvctanassa vo violacea, Tigriornis leucolophs, and Cochlearius cochlearius. Group II, with two complete tendinal canals in the hypotarsus mar be subulivided into two categories: (a) tendinal canals laterally aligneds (b) tendinal canals dorso-ventrally allgned. Group IIa is considered basic for the family. It include the majortty of the remaining forms,

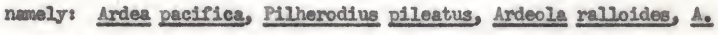
bacchus, A. speciosa, Bubutcus 2bis, D1chromanassa mufescens, Casmerodius allous modestus, Egretts intormedis, Nycticorax caledonicus, Gorsachius melanolophus, Ixobrychus exdils, Tisxisoma lineatum, and Io mexdcana.

The condition in Group IIb is considered a variant of the above condition in which one canal is superimposed above the other. It is found only in Boteurus stellaris and B. lentiginosus, and therefore alght be considered a generic character.

In Group III there are three complete tendinal canals in the hypotarsus. This occurs in Florida caerules only.

Fxenination of the distal end of the tarsometatarsus shows that 
the characteristic tendinal bridge between the third and fourth toes is complete in all adult birds. In addition, the distal foremen is present In all forms of the subfanily Ardeinae, but is absent in the subfantly Botaurinae. This condition be considered as a subfanily character for the Botaurinae, and afight possibly imply an advanced condition of the tarsal development for that gxoup.

Critical excanination of the ferur and humerus show only minor differences. In all cases variation is such that it prohibits the grouping of the herons on the basis of a fenorel or humeral character. 


\section{concLus IONS}

Intergenerie relationshipg. There is a close general similarity In the major pointe of the osteology of the herons and bitterns, of the fanily Ardeidae, and the bostmbilled heron of the fandly Cochlearildae. Because of the lack of any maxked differences of osteology, and because of the great similarity of external charecters, I propose that these three groups be treated as subfamilies within a single family, the Andeldae.

I further propose that the subfamliles be characterized as fol10พร:

Axdeinae: BIIl narrov, 12 rectrices, three padrs of powderdown patches (R1dgway, 1878).

Cochlearilnae: Bill broed, 12 rectrices, four pairs of powder-down patches (Wetmore, 1951).

Botaurinae: Bill narrow, 10 rectrices, two peirs of powderdown patches (RIdgwer, 1878).

The subfomily Adeinae, because of its large number of species, show greater variation in both qualitative and quantitative characters. These variations malce it possible to further subdivide this subfandiy. Based on the qualitative characters (Plate 1), I propose that the follouring tribes be recognised:

\section{Family Ardeldae Subfanilly Ardeinse, Herons}

of the characters plotted on Plate 1, seven are constunt within the genus Ardea, and are assuraed to be representative of the generallzed andeld form. These charseters were described in detall in Section IV and 
w1 12 be discussed here as indicators of intergeneric relationships.

These characters are:

1. Internasal septum absent.

2. Supraorbitel vacuities two.

3. Hypocleidiun truncate.

4. Articular surface of carina broad and flat.

5. Sternal facet of correcold lateral.

6. Intrenuecular line of corecold medial.

7. Tendinal groove of carpometacarpus enlarged.

Tribe 1. Ardeae, Generelized Herons. The above charracters are constent for all apecies of three genera, Andes, Butorides, and Hydrenassa. The gemus most closely related to this generalized group is Axicola, with its three species. This genus differs in only one character, the reduction of the tandinal groove of the carponetacarpus. These four genera, with the fifteen species currently asslened to then, form a rather close-lonit, generalized group, separable from the rematinder of the herons.

Tribe 2. Egrettae, Igrets. The next well defined group is composed of the following genera: Casmerodius, Exrotts, Bubuleus, Leuco= phorx, and Florlda. These forms are separated from the generalized line by the presence of an internesal septum, this being absent in the general form.

Tribe 3. Nycticoraces, Might Herons. Early in the evolution of the fanily, a basic separation must have takan place in the variation of the inferior procese of the hypoclesdium, and a corollary modifisation of the artleular surface of the carina. Both the generallzed ardeld forms and the egrets have a truncate hypocleidial process, with a broad, Plattaned articular surface of the carina. The opposing condition showe a short, 
notched hypocleidial process, with a sharply pointod articular surface of the surface of the carina. This latter condition is characteristic of the night heron line which includes the following: D1chromanassa, P1Iherodius, Syrdema, Nyctenassa, Corsachius, Iycticorex, and Exythoonus.

Iribe 4. Tiariomsthes, IIger Bitterns. A modsfication of the furculum separates the t1ger bitterns, T1griornis and Pigrisome, Irom the generalized andeld Ine in the direction of the true bitterns. This modification consists of the loss of both the superior and inferior processes of the hypocleidium, thus leaving only the amoothily rounded aper of the furculun for articulation with the shapply pointed carina. The tiger bitterns also form a transition to the true bitterns in the laterel position of the intrenuscular Iine of the coracold. This character is constant in the bitterns and occurs elsewhere in the fardy only in the two tiger bittern genera, and in Frrthocnus, of the night heron group.

\section{Subfani1y Botaurinse, Bitterns}

The subfanily Botaurinae includes the geners Botaurus and Ixobrychus. The grooved condition of the broad ventral erest of the pygostyle, separates this subsamfly from the remainder of the fanlis. In SIve characters the bitterns show a constantly reversed condition from the generalized condition.

The flve predominantly blttern characters are

2. Internasel septum always internediate.

2. Hypocloidium always short, notched.

3. Articular surface of carine always sharply pointed.

4. Intremuscular line of corracold always lateral.

5. Tendinal groove of carposetacarpus reduced esceept In Botaurus. 
Several of these charecters occur in other groups of genere anong the Axdelnae, but none of then are present in the generalized line. Only two of the generalized Ardeinae characters are shared by the bitterns.

\section{Subfardiy Cochlearlinae,}

Boat-binled Heron

of the twelve osteological charecters shown in PIato 1, the genus Cochlearius agrees most closely with the night heron group. The angulate lacrimal, short, notched hypocleidium, and lateral position of the Intraanseviar line of the coracold, however, relate it also to the bitterns, as does the broad, flat, ungrooved ventral erest of the pygostyle. A combination of the external veriation of the powder-downs, the structure of the bill, and consequent modsfication of the palate are sufficient to warrent subfantly renk within the fanily Ardeidae.

Generle diegnoses. Heretofore generic diagnoses in binds have been based upon externel characters, and the entire internal anatory has been largely negleeted below the fanlly level. The few workers in avian osteologg have usualdy been concerned with charting the amount of divergence, or mapping the qualitative variations vithin a given group.

As has been shown in the preceding section, the fandly is divisible into subfantlles and tribes on the basis of osteology. It. is posaible to continue the classification to lower taxons on the same basis. Below are presented generic diagnoses based on osteological characters. As Par as is lnown, this is the first attempt to treat an entire fandy of birds in such a manner.

In general there is a surprising amount of agreenent between the 
42

conclusions reached bere on the basis of comparative ostoology and those arrived at earlier by other workers coneerned exclusively with external characters. Certain exceptions in the current elessification, however, are pointed out below. In each case it is thought that the osteological evidence for uniting certein taxons outwelghs other considerations.

\section{Fannily Ardeidae Subfanily Ardeinae \\ Tribe Ardese}

1. Ardea: Internasal septum lacking; supraorbital vacuities always two; ectethoid variables lacrimal parallel (angulate and notched in A. pactfica); inferior process of hypocleidium truncate, superior

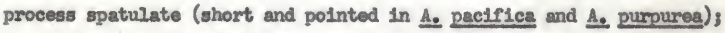
articular surface of carina always broad, flat; fibula not ankglosed to

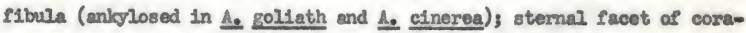
cold laterally placed; Intremuscular line of $M_{0}$ supracoracoideus and $M_{0}$ coracobrachialis posterior medial, tendinal groove of carponetacarpus greatly enlarged; hypotarsus with one complete tendinal canal (two in A. pacifice and A. purpurea).

Pre/sk 8.6-12.0; Pre/Post 50.7-62.2; Pre/Cr 25.9-34.13 Post/Cr 43.1-59.8; Pt/Q1 61.7-72.9; Ow/Q1 61.7-72.9; Qw/Q1 74.8-85.03 $\mathrm{Fe} / \mathrm{Hu} \mathrm{48.3-}$ 67.1; Fe/UI 41.2-58.63 Fe/Cne 94.7-128.2 (A. paciflea 85.0-87.3); TI/Hu 120.7-136.93 TI/U1 92.9-126.73 Ti/Cme 297.0-277.33 Ta/Hu 80.44-101.83 Tal U1 68.7-87.73 Ta/Cme 250.1-207.8; He/Hu 19.7-28.3 (1. purrourea 32.3-33.9); $\mathrm{Ha} / \mathrm{CI}$ 16.8-29.9; Ha/Gme 39.6-55.4; Hu/UI 80.3-88.73 Ra/UI 91.7-97.23 Canc/ oI 40.2-48.7; P-1/VI 14.2-18.4; P-2/U2 12.1-15.43 Fo/T1 39.3-56.8 $\mathrm{Ta} / \mathrm{TI}$ 
$68.6-60.8$; Ha/T1 $16.3-28.9$.

The genus Ardes, with the nine representative specles Included In this study, follows a relatively constant pattern with respect to qualitative characters (Plate 1). Variations occur in five of the twelve characters presented. On the basis of these variants, the followling species are apparently more closely related to one another then to the remainder of the species:

goliath and cineres: aniglosed tibia-flbula. cinerea, herodias, and occidentalis: bridged ectethnoid. paciflca and purourea: hypotarsus with two tendinal eanals.

Statistical data (Plate 2) show a different picture, however, in that only herodias and occidentalis remain difflcult to separate. Means of the ratios plotted for the two forms show an amazing degree of similarity. Further, there is complete overlap in nineteen of the twentysix ratios used in this study for herodias and occidentalis.

Masr (1956) summarized the status of occidentalis and expresses the bellef that it should be accepted only as a dimorphic subspectes of Ardea herodias.

The morphological data presented in this study substantiate the suggested subspecific rank of occidentalis. Further reference to this form will therefore be made to Ardea herodias occidentails.

2. Butorides: Internasal septum lacidng; supraorb1tal vaculties always two; ectethmold seperate; lacrinal angulate, notched; inferior process of hypocleidiun truncate, superlor process short, pointed; articular surface of carina broad, flat; fibula not ankylosed to tibia; stornal facet of coracoid lateral; Intremenscular line of M. supracoracoldeus and 
I. coracobrachialis medial; tendinal groove of carpometacarpus enlarged; hypotarsus with one complete tendinal canal.

Pre/Sk 8.7-11.9; Pre/Post 49.1-59.6; Pre/Cr 26.1-31.6; Poat/Cr 47.0-57.8; Pt/QI 67.2 -80.03 Ow/OI 80.0-90.83 Fe/Hu 62.1-74.43 5e/v1 61.668.83 Fe/Cme 123.6-138.1; T1/thu 105.5-120.3; T1/01 100.5-2u2.5; T1/Cme 195.7-220.33 Ta/tiu 70.0-79.1; Ta/U1 63.6-71.3; Ta/Cme 128.5-1/43.3; Ha/Hu $27.8-34.23 \mathrm{Ha} / \mathrm{UI} 25.3-29.6$; He/Cme 51.1-61.03 Hu/vI 88.3-92.8; Ra/

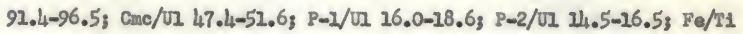
$59.6-64.45 \mathrm{Ta} / \mathrm{TL} 62.2-67.6$; $\mathrm{Ha} / \mathrm{TI} 24.1-27.9$.

The genus Butorides is inseparable from the generalired axdeid form on the basis of the seven characters listed above. It differs from the general form in only one of the flve other characters mentioned. In this character, the superior process of the hypocleidivu, Butorides is rolated to Ardea pacifica and A $_{\text {purpures }}$ in having a short, pointed process.

Within the genus, the two species of Butorides are inseparable on osteological grounds, elther qualitatively, or quantitatively. Thus, the two species are now referred to the species striatus, with striatus and Irescens as subspecies (Linnaeus, 1758).

3. Ilydranassa: Internasal septum lackelng; supraorbital vaculties always two 3 ectothmold separate; lacrimal angulate, notchod; in. ferlor process of hypocleidium truncate, superior process spatulate; articular surface of carina broad, Ilats fibula not ankylosed to tibias - stemal facet of coracoid lateral, intranuscular line of $K_{0}$ supracora-

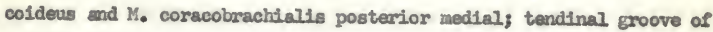


carponetacarpus enlarged; hypotaraus with one complete tendinal canal. Pre/Sk 8.2-9.2; Pre/Post 49.8 -58.5; Pre/Cr 2/4.5-28.2; Post/Cr W4.8-52.7; Pt/O2 71.5-79.7; $\mathrm{Ow} / \mathrm{OI}$ 87.1-95.4; $\mathrm{Fe} / \mathrm{Hu} 57.6-60.03 \mathrm{Fe} / \mathrm{UI}$ 48.4-51.0; $\mathrm{Fe} /$ Gave 97.6-105.3; TI/liu 1214.9-1/46.03 T1/01 105.3-124.83 T1/Cne 213.5-257.6; Ta/Hi 93.3-108.3; Ta/نi 77.9-92.1; Ta/Gne 161.3189.93 Ha/Hu 27.1-29.7; Ha/U工 23.0-25.4; Ha/Canc 47.8 -52.53 Hu/v1 82.985.5; Ra/v1 94.9-96.53 Cnc/U1 47.8-50.9; P-1/U1 16.4-18.0; P-2/U1 12.6 15.4; Fe/T1 40.8-246.1; Ta/T1 70.0-77.7; Ha/ 191 19.0-22.6.

is in Butorides, Hydranassa is related directly to the generallzed ardeld form in all of the seven listed characters. Further, only ane of the IIve other characters shows a difference from the general form. This, as in the former genus, relates to the angulate, notched lacrimal characteristic of Ardea pacifica.

4. Ardeola: Internasal septun lacking; supreorbital vacuities alvays two ectethnoid separate; lacrimal angulate, notched; inferior process of hypocleidium truncate, superior process short, pointed; articular surface of carina broad, rlat; fibula not ankylosed to tibiag stemal facet of coracoid laterel, intrawuscular line of $U_{0}$ supracora-

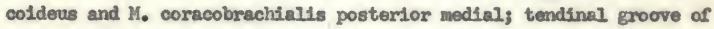
carponetacarpus reduced; hypotarsus with two complete tendinal grooves. Pre/Sk 10.7-12.2; Pre/Post 49.5-54.5; Pre/Cr 28.2-31.2; Post/Cr

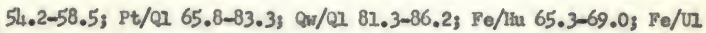
56.5-62.1; $\mathrm{Pe} / \mathrm{Gne}$ 115.9-120.8 (스 speciosa 126.3, one specinen); T1/UL 97.9-101.6 (A. specioga 82.2, one specimen); T1/Cme 193.0-213.3 (A.

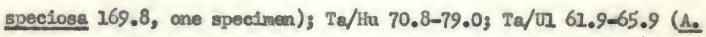


speciosa, one specinen); Ta/Cme 119.4-147.0; Ha/Hu 27.8-30.9; Ha/UI $24.1-27.93 \mathrm{He} / \mathrm{Cnc}$ 46.9-57.53 Hu/OI 84.9-87.5 (A. speciosa 90.1; ane specimen); Ra/UI 24.3-95.3; Cme/UI 47.6-51.9; P-1/UL 26.5-17.8; P-2/ TI 15.4-17.6; Fo/T1 55.6-60.1 (1. speciosa 75.6, one specimen); Ta/T1 61.9-66.9 (A. speciose 86.6; one specimen); Ha/ri 23.2-26.0 (A. speciose 33.9 , one specimen).

Andeola agrees with the generalized ardeld fom in six of the seven general characters. The three species of this genus have a such reduced tendinal groove of the carponetacarpus in contrast with the prominent groove in the generallzed ardeld form. In other characters, Ardeola agrees with Butorides in having a short, pointed superior process of the hypocleidium, and an angulate, notched lacrimal. Ardeola is related to Andes pacifice, and A. pursourea in the same manner. The species of Ardeola agree in their qualitative characters, but are soparable statistically.

\section{Tribe Esrettae}

1. Casmerodius: Internasal septum 1ntermediate; supreorbital vacuities always two ectethmoid separate; lacrimal para3lel, "I" shaped; Infarior process of hypocleidium truncate, superior process spatulate; articular surface of carina broad, Nat; fibula ankylosed to tibia at distal and; sternal facet of coracoid medially placed, intrenuscular

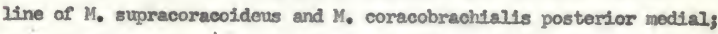
tendinal groove of carponetacarpus reduced; hypotarsus with one complete tendinal canel.

Pre/Sk 7.8-9.3; Pre/Post 51.8-62.6; Pre/Cr 23.0-29.0; Post/Cr 


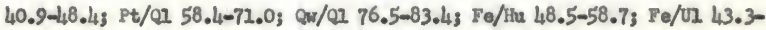
46.0; $\mathrm{Fe} / \mathrm{Cme} 97.6-103.1 ; \mathrm{TI} / \mathrm{Hu}$ 122.7-151.5; T1/01 $121.4-126.4 ; \mathrm{TI} /$ Ganc $248.4-278.13 \mathrm{Ta} / \mathrm{Hu} 94.9-210.4 ; \mathrm{Ta} / \mathrm{UL}$ 83.2-92.2; Ta/Cne 187.2-207.5; Ha/ Hu 23.3-27.7; Ha/UI 19.8-21.7; Ha/Cmo 44.5-51.2; Hu/ UI 81.0-85.5; Ra/UI 90.7-97.6; Cme/v1 42.3-46.2; P-1/U1 15.0-16.5; P-2/U1 13.2-14.2 (ci: modestus 15.4, one specinen); Fe/T1 35.8-39.6; T2/T1 71.2-77.7; He/T1 16.0-19.2.

The monotyplc genus Casmerodius agrees with the genus Egretts and is distinguished from the other egrets by the medial position of the stemal facet of the coracoid. It further differs from the generalised ardeid form in having the fibula aniglosed to the tibia at its distal and. The condition of the lacrimal bone of Casmerodius 18 unique anong the herons. An anterlor projection of the inf orlor process of the Iscrimal is present which gives this bone the appearance of an "In.

2. Eirettas: Internasal septum internediates supraorbital vaculties always two; octethmold separate, lacrinal angulate, notched, in-" ferior process of hypocleidiun truncate, superior process spatulate, articular surface of carina broad, flat; tibla-fibula relationship variable, ankylosed in $\underline{B}_{0}$ intermedias, not in $\underline{E}_{0}$ garzettas sternal facet of coracoid medial, intraruscular line of $U_{0}$ supracoracoidens and $M_{0}$ corecobrachsals posterlor medial; tendinal groove of carponetacarpus enlarged; condition of hypotarsus varlable, E. garzetta with one complete tendinal canal, $\underline{E}_{0}$ internedia with two complete tendinal canals.

Pre/Sk 9.6-10.8; Pre/Post 48.5-51.8; Pre/Cr 27.2-28.7; Post/Cr 54.8-56.4; Pt/OI 63.9-73.5; Ow/QI 83.5-88.6; Fe/Hu 53.0-60.9; $\mathrm{Fe} / \mathrm{UI}$ 
44.0-52.1; Fe/Cme 96.3-108.6; T1/Hu 129.2-157.33 T1/v1 216.9-127.3; $\mathrm{TI} / \mathrm{Cmc} 240.7-269.6$ Ta/Hu 93.6-104.1; Ta/v1 78.9-87.63 Ta/Gne 173.0289.3; Ha/Hu 25.2-28.93 Ha/U工 20.2-24.03 Ha/Cmc 44.2-52.6; $\mathrm{Hu} /$ UI 75.9 87.4; Ra/UI 95.2-96.6; Cmc/U1 45.1-47.9; P-1/UI 15.8-17.6; P-2/UI 14.0-26.93 $\mathrm{Fe} / \mathrm{T1} 37.7-44.1 ; \mathrm{Ta} / \mathrm{TI} 66.9-74.6 ; \mathrm{He} / \mathrm{T1}$ 17.1-20.6.

The gemus Erretta, with its two species, diffors from Casmerodius in having a greatly enlarged tondinal groove of the carpometacarpus. This groove is wuch reduced in Casmerodius. Thus, Ecretta, is simdlar to the ardeid form in $81 x$ of the generalised characters. It is related to Casmerodius in all other characters except the condition of the inferior process of the lacrimal. Egretta has the angulate, notched inferior process of the lacrimal which is characteristic of the genus Butorides and Ardes pacifica.

3. Bubulcus: Internasal septum Intermediate, supraorbital vacuities always two; ectethmoid separate; lacrimal angulate, notched; inferior process of hypocleidiun truncate, superior process short, pointed; articular surface of carina broad, Plat; flbula ankylosed to tibia at distal end; sternal facet of coracold lateral, intremuscular line of $M_{0}$ supracoracoldeus and $M_{0}$ coracobrachlalis posterior medial; tendinal groove of carpometacarpus enlerged; hypotarsus with two complete tendinal canals.

Pro/Sk 10.8-11.9; Pre/Post 43.8-47.2; Pre/Cr 25.9-29.0; Post/Cr 57.4-61.7; Pt/Q1 66.1-78.2; Ow/Q1 86.6-91.23 Fe/Hu 56.3-61.63 Fe/UI 48.1-53.0; Fe/Gne 106.2-115.23 T1/Hu 122.0-137.43 T1/OI 105.7-108.53 TI/Cne 232.4-236.0; Ta/Hu 85.8-91.43 Ta/UI 74.8-78.63 Ta/Cac 264.3-170.93 
$\mathrm{Ha} / \mathrm{Hu}$ 85.8-91.4; Ha/OI 24,.2-26.7; Ha/Cme 53.0-58.0; Hu/ U1 95.7-96.5; Gme/UI 45.3-56.1; P-1/U1 26.6-18.5; P-2/U工 15.5-16.6; Fe/ TI 45.5-19.0; Te/T1 70.4-72.4; Ha/TI 22.7-21.6.

- The monotypie genus Bubulcus agrees with Leucophoyx and Blorida, and differs from Casmerodius and Beretts in having a lateral position of the sternal facet of the coracoid, thus forming a group of "lesser egrets". Bubulcus is separated from Loucophorx and Forida on the basis of the internasal septur. In Bubulcus the Septum is internediate, but in Levcophorx and Foride the septum is entire.

Bubulcus differs from the generalized ardeld line in one of the seven basic characters. This character, however, is considered the key character for the egret group. Bubuleus further differs from the general Iine in two of the other IIve characters, these being the angulate, notched inferior process of the lacrimal, and the fact that the fibula Is ankylosed to the tibia at its distal and.

4. Leucophorz: Internasal septum present; supraorbital vaculties always two; ectethnoid separate; lacrimal angulate, notched; inferior process of hypoclesdiun truncate, superior procees spatulates articular surface of carina broed, flat; fibula not aniglosed to tiblas sternal facet of coracold lateral, Intranuscular line of $M_{0}$ supracorecoldeus and $M_{0}$ coracobrachialis posterior medial; tendinal groove of carponetacarpus onlarged; hypotarsus with one complete tendinal canal.

Pre/Sk 9.2-11.1; Pre/Post 45.5-47.7; Pro/Cr 27.0-29.8; Post/Cr 55.7-60.1; Pt/O2 66.4-81.5; Ow/ez 82.5-89.5; Fe/thu 55.4-60.0; $\mathrm{Fe} / \mathrm{VI}$ 46.4-50.1; Fe/Cac 96.3-107.6; T1/liu 137.0-145.0; T1/01 123.9-122.6; 
T1/Gme 238.9-270.45 Ta/Hu 101.4-105.15 Ta/U1 83.5-93.9; Ta/Gme 177.3206.35 Ha/thu 23.4-29.03 Ha/OI 21.1-24.83 Ha/Cnc 45.2-51.43 Hu/U1 82.284.4; Ra/O1 95.3-97.1; Cnc/U1 45.3-48.43 P-1/U1 15.7-17.0; P-2/U1 24.315.6; Fe/ $\mathrm{II} 39.2-43.2$; Ta/T1 69.9 -80.2; Ha/T1 17.6-21.2;

The genus loucophoyx, as indicated above, shows very close relationship to Florida. On the besis of the generallzed andeid characters, these differ only in the depth of the tendinal groove of the carpometacarpus. In Leucophoyx the groove is enlarged, and In Florlde it is much reduced. In other qualitative characters these two forms are identical with the exception of the condition of the hypotarsus. Leucophoyx has only one complete tendinal canal, the other two being open grooves. In Ploride three complete canals are present through the roofing of the grooves.

5. Floridas Internasal septum present; supreorbital vacuitios alwajs two; ectethmold separate; lacrinal angulate, notched; inferior process of hypocleidium truncate, sugerior process spatulate; articular surface of carine broad, Plat; Ifbula not ankglosed to tibia; sternal fecet of coracoid lateral, intramuscular line of $\mathrm{M}$. supracoracoldeus and M. coracobrachialis posterior medial; tendinal groove of carponetacarpus reduced; hypotarsus with three conplete tendinel canals.

Pre/Sk 9.1-10.7; Pre/Post 44.9-49.6; Pre/Cr 25.7-28.5; Post/Cr 55.8-61.1; Pt/Q1 70.4-79.53 ow/O2 83.6-89.2; Fe/Hu 56.1-59.3; Fe/un 47.4-50.8 $\mathrm{Fe} / \mathrm{Cme} 98.7-203.4 ; \mathrm{TI} / \mathrm{Hu}$ 132.6+1146.7; T1/v1 213.0-125.7; TI/Cane 227.3-258.8; Te/hu 94.9-107.6; Ta/U1 80.7-89.5; Te/Gme 166.5185.0; Ha/Hu 27.2-30.3; Ha/OI 23.0-26.0; Ha/Cac 47.2-54.2; Hu/UI 82.1- 
86.7; Ra/U2. 95.3-96.6; Cnc/UL 46.6-50.6; P-1/U1 16.7-18.7; P-2/UL 12.325.63 Fe/T1 39.4-4l3.4; Ta/T1 69.5-75.6; Ha/T1 19.1-21.4.

As indicated above, Plorids caerviles is separated from Leucophorx thuls by the depth of the tendinal grooves of the carpometacaryous and the condittion of the hypotarsus.

The means of five of the ratios are identical for caerules and thula. The ranges of the remaining twenty-one ratios show alnost complete overlap with the means of only two ratios being separated by nore than two per cent.

On the basis of these data it becomes necessary to comblne these two supposed genera. Leucophorx Shaxpe 1894 is hereby synonymised with Moride Befrd 1858. Future reference will be mede to the snowy egret as Foride thula, with the revised generic diagnoses for Florida as follows:

Plorida: Internasel septum present; supraorbital vacuities always two; ectethmoid separate; lacrimal angulate, notched; inferior process of hypoclasdium truncate, superior process spatulate; articular surface of carina brosd, flat; fibula not ankglosed to tiblaj sternal facet of coracold lateral, intravuscular line medial; tendinal groove of carpometacarpus variable; hypotarsus with one or three tendinal canals.

Pre/Sk 9.1-11.1; Pre/Post W4.9-49.6; Pre/Cr 25.7-29.8; Post/Cr 55.7-61.1; Pt/Q1 66.4-81.5; Ow/01 82.5-89.53 Fe/llu 55.4-60.0; Fe/v1 46.4-50.8; Fe/Cne 96.3-107.6; T1/fiu 132.6-146.73 T1/V1 123.0-125.7;

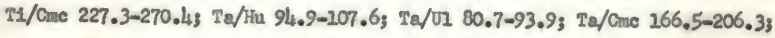
He/the 23.4-30.3; Ha/OI 21.1-26.0; Ha/Cme 45.2-54.2; Hu/ Or 82.1-86.7; 
51

Ra/or 95.3-97.1; Cne/OI 45.3-50.6; P-1/U1 15.7-18.7; P-2/U1 12.3-15.6;

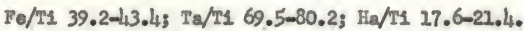

\section{Tribe Nycticoraces}

1. Dichronanessa: Initernasal septum lacking; supreorbital vaculties always two; ectethnold separate; lacrimal angulate, notched; infertor process of hypocleidium short, notched, superfor process spatulates articular surface of carina pointed; fibula not aniglosed to tibia; stemal facet of coracoid lateral; intramuscular line of $M_{0}$ supracoracoldeus and $\mathrm{H}_{0}$. coracobrachials posterlor medial; tendinal groove of carponetscarpus reduced; hypotarsus with two complete tendinal cansis.

Pre/sk 9.5-10.3; Pre/Post 47.5-49.8; Pre/Cr 27.3-29.1; Post/Cr

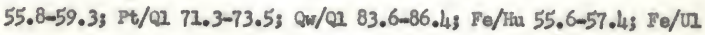
46.3 -47.43 Fe/Cme 96.4-98.2; Ti/Hu 135.9-149.8; $\mathrm{TI} / \mathrm{VI} 112.6-123.13 \mathrm{TI} / \mathrm{Cme}$ 230.7-258.6; Ta/thu 102.0-120.3; Ta/UI 84.4-99.3; Ta/ Gne 175.9-206.0; $\mathrm{Hla} / \mathrm{Hu} 22.1-23.3$; $\mathrm{Ha} / \mathrm{OI} 18.3-19.1 \mathrm{Ha} / \mathrm{Gmc} 38.1-40.2 \mathrm{H} \mathrm{H} / \mathrm{UL}$ 82.2-84.83

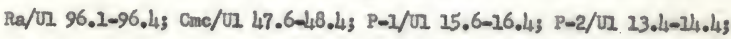
Fe/T1 37.6-41.8; Ta/T1 81.7-84.5; Ha/Ts 15.5-16.6.

The night herons are divided into two divergent lines on the basis of the depth of the tendinal groove of the carpometacarpus. One Iine, having a reduced tendinal groove, includes Dichromanasse, P1Iherodius, Syrigme, and Nyctanassa. The other 21ne, with an enzarged tandinal groove, Includes Gorsechius and Nrcticorax.

Further separation of the fIrst group is made on the basis of the Internasal septum. Thls septrm is absent in Dichromanassa, thus separating the genus from the group in the direction of the Ardeae. This 
gemus differs from the Ardeae in three of the general characters, the condition of the hyopcleidiun (short, notched), the articular surface of the carins (sharply pointed), and the condition of the tendinal groove of the carpometacarpus (reduced).

2. PIIherodius: Internasal septum preaent; supreorbital vacuities always two; ectethmold bridged; lacrimal angulate, notched; Inferlor process of hypocleidium short, notched, superior process spatulato; articular surface of carlna pointed; f1bula not ankylosed to tibias sternal frcet of coracold lateral, intranuscular line of $\mathrm{M}_{0}$ supracoracoldeus and $U_{0}$ coracobrachialts posterior medial; tendinal groove of carponetacarpus reduced; hypotarsus with two parallel tendinal canels.

Pre/Sk 9.6-10.2; Pre/Post 45.9-49.6; Pre/Cr 26.2-28.9; Post/Cr 56.1-58.3; Pt/Q1 67.4-73.1; Ow/Q1 84.7-88.9; Fe/Hu 60.7-65.1; $\mathrm{Fe} / \mathrm{VI}$ $46.8-52.7 \mathrm{Fe} / \mathrm{Cme} 102.5-110.7 \mathrm{FI} / \mathrm{Hu} 136.4-139.9$; TI/UI 106.3-110.03

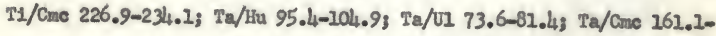

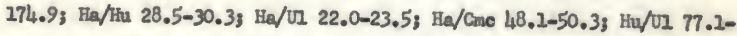

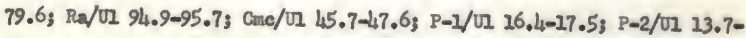
L.63 Fe/T1 44.0-47.9; Ta/T1 69.2-75.0; Ha/T1 20.7-22.2.

Pilherodius is related to the general night heron line as indicated above, but differs Prom Dichromanassa in heving an entire internasal septum. This genus further differs from the Ardeae in two other generallized characters set forth for that group. P1lherodius has a short, notched hypocleidial process, and a sharply polnted articular surface of the carina. It differs from the Ardeae also in having an angulate, notched inferlor process of the lacrimal, a short, polnted auperior 
process of the hypocleidiun, and two corplete tendinal canals in the hypotarsus.

3. Syrigma: Internasal septum intermediate; supraorbital vacuities always two; ectethrold bridged; lacrimal angulate, notched; Inferior process of hypocleddium short, notched; superior process short, pointed; articular surface of carine pointed; IIbula not anklosed to tibias sternal facet of coracoid laterel, intranuscular line of $M_{0}$ supracoram coldeus and $M_{0}$ corecobrachialts posterior medial; inpotarsus with one complete tendinal canal.

Only one specimen was available for measurement for quantitative characters:

Pro/Sk 11.3. Pre/Post 46.1; Pre/Cr 27.2; Post/Cr 59:0; Pt/QI

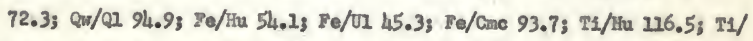
U1 97.7; T1/Cme 201.9; Ta/Ha 85.1; Ta/ U1 71.3; Ta/Che 147.5; Ha/thu 20.73

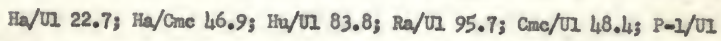
27.5; P-2/U1 U14.8; Fe/T1 $46.43 \mathrm{Ta} / \mathrm{T1} 73.0$; Ha/T1 23.2.

Syrigme and Nyctanasse agree with Dichromanasse and Pliherodius In the characters set forth above, but differ from those in hoving an intermediate internasal septum. Syrigma differs from Nyctanesse in having oniy two supreorbital vacuities, and in a bridged ectethmoid. It further differs from the Ardeas in having a bridged ectethmo1d, an angulate, notched lacrimal, and a short, pointed superlor process of the hypocle1dives.

4. Nyctannssa: Internasal septumilintermediate; supreorbital vacuities lacking; ectethmoid separate; lacrimal angulate, notched; 
54

Inferior process of hypocleidium truncate, superlor process spatulate; articular surface of carina broad, flats fibula ankglosed to tibla at distal and; sternal facet of coracold lateral, intramuscular line of $M_{0}$ supracoracoideus and $\mathrm{I}_{\text {. }}$ coracobrachialis posterior medial; tendinal groove of carpometacarpus reduced; hypotarsus with one complete tendinal canal.

Pre/Sk 12.3-13.5; Pre/Post 42.6-49.4; Pre/Cr 28.1-31.6; Post/Cr

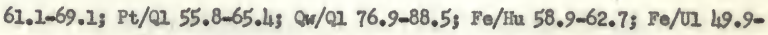

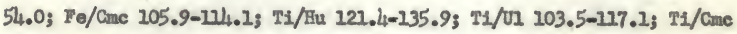
215.8-2147.43 Ta/ Hu 89.3-99.6; Ta/Uב 75.6-814.0; Ta/Cne 159.6-177.5;

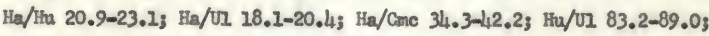
Ra/on 94.3-96.3; Cmc/VI 46.5-49.0; P-1/VI 12.9-15.93 P-2/U1 26.2-18.4; $\mathrm{F} \times / \mathrm{TI} 44.1-49.7 ; \mathrm{Ta} / \mathrm{TI} 69.0-76.8 ; \mathrm{Ha} / \mathrm{T1}$ 16.5-18.9.

Nyctanasse agrees with the generalized andeid Ine in the sane general mamer with respect to the characters set forth above but differs from Sympas, in having no supraorbital vacusties, and in having the fibula ankylosed to the tibla at its distal end.

5. Gorsachius: Internasal septum Internediate; supraorbital vacuities two; ectethmold separate; lacrimal angulate, notcheds inferior process of hypocleidium short, notched, superior process apatulates articular aurface of carina pointed; fibula ankylosed to tibla; stemal facet of coracold lateral, intranuscular line of $M_{\text {. supracora- }}$ coldeus and $\mathrm{K}$. coracobrachialis posterior medial; tendinal groove of carponetacarpus enlarged; hypotareus with two complete tendinal canals. Only one specimen avallable for measurenent for quentitative 
characters:

Pre/Sk 13.3; Pre/Post 43.1; Pre/Cr 27.1; Post/Cr 62.8; Pt/Q1

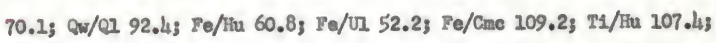
T1/U1 92.13 TI/One 192.83 Ta/Hu 71.83 Ta/v1 61.6; Ta/Cne $128.93 \mathrm{H} / \mathrm{H} / \mathrm{Hu}$

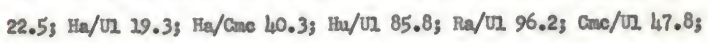
$P-1 /$ VI 16.6; P-2/U1 13.3; Fe/TL 56.6; Ta/T1 66.9; Ha/T1 20.9.

Corsachlus and Nrcticorex differ Irom the above. mentioned night herons in having an enlarged tendinal groove. Gorsachius differs from Nycticorax in having two supreorbital vecuities, instead of four, and In the internasal septrm being intermediate instead of entire. It further differs from the generalized ardeld line in having a short, notched hypocleidial process, and in having the fibula fused to the tibia at its distal end.

6. Nycticorax: Internasal septum present, intermediate in $\mathrm{N}$. celedonicus; supraorbital vaculties four, sometimes incomplete in ‥ caledonteus; ectethmosd bridged; lacrimal angulate, entires inforlor process of hypocleldium short, notched, superior process spatulates articular surface of carine pointed; fibula not ankylosed in № nveticorax, ankylosed in ‥ esledonicus; sternal facet of coracold lateral, Intravuscular IIne of M. supracoracoldous and M. corecobrachialls posterlor medial; tendinal groove of carponetacarpus enlarged; hypotarsus with one complete tendinal canal in 1 . nycticorax, two in 1 . caledonicus. Pre/Sk 12.0-13.9; Pre/Post 43.0-53.03 Pre/Cr 29.2-32.3; Post/Cr

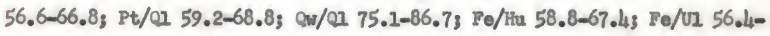

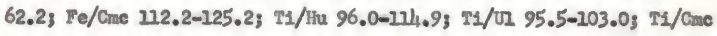


187.4-210.5; Ta/thu 61.8-76.6; Ta/U1.60.7-68.6; Ta/Cun 122.5-135.9; Ha/thu

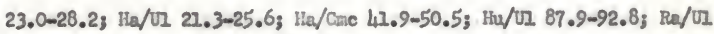
94.5 -97.0; Cnc/UI 46.9-54.0; P-1/V1 15.5-19.2; P-2/U2 13.4-16.9; Fo/TI $57.6-62.3 ; \mathrm{Ta} / \mathrm{TI} 61.5-67.8 \mathrm{H} \mathrm{Ha} / \mathrm{T1} 21.5-25.2$.

The genus Nycticorex is separated from Gorsechlus as indicated above. In addition to the general night heron characters, it further differs from the generallsed ardeld form in having four supreorbital vacutties, and an entire internasal septura. It differs from the genecral form also in having a bridged octethmold. The two apecies of lircticorex agree in all qualitative charecters except the condition of the tiblaPlbula, II. nyoticorax having a free P1bula, No caledonicus having the Sibula fused to the tibla at the distel end. The hypotaras of $\mathbb{N}$. nyeticorax has only one complete tendinal canal, whllo N. calodonleus has two such canals.

7. Brythocnug: Internasal septum lacling; surpraorbital vaeuities always two; ectethrold separates lacrimel angulate, notched; inferior process of hypocleidium short, notched, superior process pointed; articular surface of carina pointed; P1bula not aniglosed to tibla; sternal facet of coracold lateral, Intramascular line of $M_{0}$ supracoracoldeus and $\mathrm{Y}$. coracobrachials posterior medial; hypotarsus with one complote tendinal canal.

Pre/Sk 11.6-12.2; Pre/Post 51.9-55.3; Pro/Cr 28.6-29.8; Post/Cr

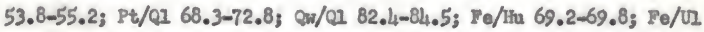
61.8-62.4; Fe/Cne 122.2-1214.7; T1/Hv. 10\%.0-122.3; T1/U1 97.4-100.2; TI/ Cane 194.8-198.3; Ta/Hu 70.2-72.83 Ta/OI 63.0-65.13 Ta/Gme 126.0-128.6; 
Ha/thu 26.6-27.7; Ha/r 23.8-24.5; Ha/Cme 47.5-48.5; Hu/U 89.4-89.43 Ra/ U1. 94.7-95.6; Che/UI 50.0-50.6; P-1/U1 16.9-17.6; P-2/01 15.5-15.7; $\mathrm{Fe} /$ T1. $61.6-64.0 ; \mathrm{Ta} / \mathrm{TI} 63.0-64.8 \% \mathrm{Ha} / \mathrm{TL} 21.44-24.9$.

. Fyxthocurus apparently separated from the besie night haron line shorthy after 1ts divergence fram the generalized ardeid form. Such a change comes as a modification in the position of the intranruscurar line of tho coracold, this being lateral in position in Brythocmus, and modial In the remeining Nycticoraces, the Egrettae, and the Ardese. The lateral position of this line in Exythocnus corresponds with the condition in the Iigriornithes, the Cochlearitinae, and the Botaurinne. Brythocmus agrees with Dichromanassa, and the generelised line in having no intornasal septum. It further agrees with the Ardeae in having an entarged tendinal gxoove of the carpometacarpus. It agrees with the Nycticoraces in the remaining qualitative characters.

\section{Tribe Tieriornt thes \\ Iiner B1tterns}

1. Tieriornis: Internasal septun Internediato; supraorbitel vacuities fours inferior process of ectothmoid laciding, superior process much reduced; lacrimal angulate, notched; Inferlor and superior processes of bypocletdium lacidng, furculum prescribing a amooth ourve; articular surface of carina pointed; Pibula not ankylosed to tibieg sternal facet of coracoid lateral, intranuscular line of $\mu_{*}$ supracoracoldous and $Y_{*}$ coracobrachialis posterior lateral; tendinal groove of carponetacarpus enlarged; hypotarsus with one complete tandinal canal.

Pre/Sk 10.3-10.8; Pre/Post 52.4-56.5; Pre/Cr 27.2-29.5; Post/Cr 
There is no page 58; the text is continous, but there has been an error in pagination. 
51.8-52.3; Pt/Q1 76.3-80.93 9w/Q1 81.6m84.23 Fe/thu 80.8-81.33 Fe/U1 69.0 71.03 Fe/Cine 157.41-161.9; TI/Hu 125.2-129.63 T1/VI 110.0-210.0; T1/Cuc

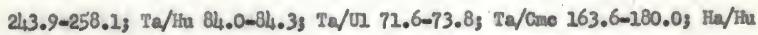

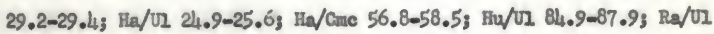

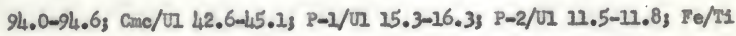
62.8-0́4.63 Ta/11 65.1-67.13 Ha/T1 22.7-23.3.

Tierlornis differs from the Ardeae in having a conglete internasal septum, four supraorbitel vacusties, a complete rechuction of the inferior process of the ectethmoid, an anuglate, notched lacriann, no hypocleidial process, a sharply pointed articular process of the carina, and a lateral Intramuscular line of the coracold. All these characters relate it directiy to the Botaurinae. Migriornts is separated from Figrisome by having four supraorbital vacuities, and an entire internasal septum.

2. Tigrisona: Internasal septum variable, present in fo mexdcans, intermediate in I. Iineaturgs supraorbital vacusties laciding; ectethmold separate; lecrimal parallel; inferlor process and superior process of hypocleidium lacking, furculum forning a smooth curves articular surface of carina pointed; flbula not ankylosed to tiblas sternal facet of coracold lateral, intranuscular line of $\mathrm{X}_{0}$ supracoracoldeus and $\mathrm{K}_{0}$ coracobrachialis posterior lateral; tendinal groove of earpometacarpus onlargeds hypotarsus with two complete tendinal canals.

Pre/Sk 8.7-10.53 Pre/Post $44.5-53.23$ Pre/Cr 23.4-28.8; Post/Cr

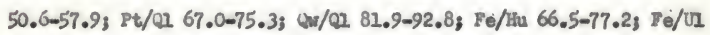
$58.0-67.33 \mathrm{Fe} / \mathrm{Cme} 128.9-1 / 11.93 \mathrm{TI} / \mathrm{Hu}$ 121.4-131.03 TI/UI 102.7-108.73 
T1/Cne 229.1-2140.73 Ta/Hu 87.0-95.0 3 Ta/U1 72.2-78.93 Ta/Cinc 159.9-174.5;

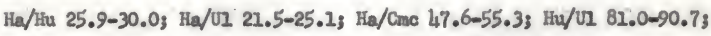
Ra/UI 93.8-96.9; Cmc/U1 W4.3-46.0; P-1/U1 14.7-16.4; P-2/UI 12.0-14.1; Fe/T1 55.1-61.2; Ta/T1 67.8-72.5; Ha/T1 19.8-2h.0.

Tigrisoma differs fron the Ardeae in the manner of Tigriomis, but with internasal septum intermediate rather than entire, and with the supraorbital vacuities abeent. These two charecters are also used to separate the two genera, Tigrisona and Figriornis, both of which shore sinilar affinities to the Botaurinse.

\section{Subfamily Cochleariinae Boat-bi Iled Heron}

1. Cochloarius: Internasal septum lacking; supreorbital vaculties lacking; inferior process of ectethmoid laclding, superior process wuch reduced; lacrinal angulate, notohod; inforior process of hypocle1dius short, notched, superior process spatulate; articular surface of carina pointed; fibula not ankglosed to tibla; sternal facet of corecoid lateral, intramuscular line of M. supracoracolders and M. corscobrachialis posterior lateral; tendinal groove of carpometacarpus reduced; hypotarsus with one complete tendinal canal.

Pre/Sk 15.8-17.7; Pre/Post 50.7-58.4; Pre/Cr 35.2-42.0; Post/Cr $69.4-70.3 \mathrm{Pt} / \mathrm{QI}$ 63.9-68.93 Qw/Q1 93.8-95.8; $\mathrm{Fe} / \mathrm{llu} 69.7-79.3 \mathrm{~F} \mathrm{Fe} / \mathrm{UI}$ 59.5-62.43 Fo/Cme 135.1-136.93 T1/Hu 129.9-129.5; TI/U1 105.8-210.63 T1/Cme 232.1-252.0; Ta/Hu 78.0-86.93 Ta/U1 68.9-74.3; Ta/Cme 151.0-

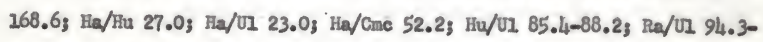
94.93 Gac/U1 44.1-L5.6; P-1/U1 17.1-17.5; P-2/O1 13.9-15.5; Fe/T1 53.8 
59.0; Ta/11 65.1-67.2; tia/11 20.8.

In addition to the external charactars of the subfanily CochleariInwe, the generie diagnosis of Cochlearius relates this genus to the Egrettee, the ilycticoraces, the Migriomithes, to one genus of the Andeae, and to the subfandly Botaurinas. The expanded condition of the bill, with the resultant modifleations of the palate, are characteristic only of Cochloarlus.

\section{Subfand Iy Botaurinee \\ Bitterns}

1. Botaurus: Internasal septum interned1ate; supraorbital vaculties alwars two; ectethmold separate; lacrimal angurate, notched; inferior process of hypocleidium short, notched, superior process short, pointed; articular surface of carina pointed; fibula not ankglosed to tiblas sternal facet of corscold lateral, Intrenuseular line of $U_{0}$ supracora-

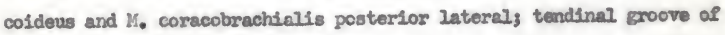
carponetacarpus enlarged; hypotarsus with two complete tendinal cenals, one lying posteromlateral to the other.

Pre/Sk 12.0-13.3; Pre/Post 54.5-62.9; Pre/Cr 25.9-32.83 Post/Cr 47.4-54.9; Pt/e1 59.2-69.6; $\mathrm{w} / \mathrm{OL} 72.2-81.6 ; \mathrm{Fe} / \mathrm{Hu} 71.3-75.43 \mathrm{Fo} / \mathrm{Gl}$ 64.4-69.7; Fe/Cnc 221.0-138.4; T1/Hu 2च1.3-122.5; Ti/v1 105.1-112.7; Ti/Cnc 195.6-215.9; Ta/Hu 72.8-86.45; Ta/UI 67.0-79.13 Ta/Cane 133.2-151.43 Ha/Hu 27.2-34.1; Hla/UL 24.9-31.5; Ha/Gne 49.6-59.2; Hu/OI 89.8-93.73 Ra/U1 94.2-96.1; Gmo/U1 50.0-53.2; P-1/U1 15.1-19.1; P-2/U1 12.4-15.2; $\mathrm{Fe} / \mathrm{T1}$ 59.6-65.4; T2/T1 62.9-71.33 Ha/T1 23.7-29.5.

Botaurus agrees with the Ardeas in having two supreorbital 
vacuities, with the sternal fecet of the coracold lateral, and in having a grestly enlarged tendinal groove of the carponetacarpus. It differs from the Ardeae In having an internediate Internesal septum, a separated ectethno1d, an angulate, notched lacrimal, a short, notchod inferior process of the hypocleidium, a short, pointed superfor procees of the hypocloidiun, a sharply polnted articular surface of the carina, and a laterally placed intramuscular line of the coracold.

2. Ixobrychus: Internasal septuin Intermediate; supraorbital vacuitiles elways two; ectethmoid separate; lacrimal angulate, notched; Inferior process of hypocleidiun short, notched, superior process short, pointed; articular surface of carine pointed; fibula not ankglosed to tibla; sternal facet of coracoid lateral, intramscular line of $U$. sugrecoracoldeus and $M_{0}$ coracobrachlalss posterior laterel; tendinal groove of carpometacarpus reduced; hypotarsus with two complete tendinal canals.

Pre/Sk 10.0-23.5; Pre/Post 49.7-60.3; Pre/Cr 25.5-32.3; Post/Cr 46.8-55.1; Pt/QI 60.8-84.63 ow/OI 75.8-90.9; Fe/liu 83.0-90.9; except I.

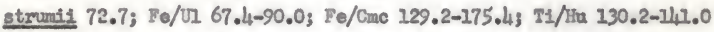
(I. strunis 171.8 ; and I. involueris 153.0); T1/VI 120.7-138.0, (I. strunds 104.6); Ta/Ciac 251.3-275.1, (I. strumil 198.6, and I. cinnae

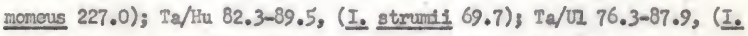
strumis 64.6); Ta/Cmc 167.1-175.2 (I. strumi11 123.8, and I. cinnamomeus Ii3.4); Ha/Hu 30.5-38.73 Ta/U1 28.2-31.5; Fia/Canc 54.1-74.53 Fiv/ U1 92.6-99.4; Ra/UI 92.5-95.9; Cmc/UI 49.5-53.2; P-1/VI 16.3-18.0; P-2/UI 13.8-16.43 Fe/TI 62.4-66.2; Ta/T1 62.0-66.6; Ha/T1 25.1-28.4. Irobrychus asroes with the Ardeae in the same manner as Botaurus 
except that it has a reduced tendinal groove of the carpometacarpus. This character also serves to separate Ixobrychus from Botaurus. Ixobrychus differs from the Ardene in the same manner as Botauras with the addition of the character mentioned above: 


\section{SUMMARY}

As the present elassification of the avlen fantlies Ardeldae and Cochlearildae is founded primarily upon external characters and has rosulted in the recognition of a large number of monotypic genera, 1t was thought that a study of the osteology ulight afford an insight into the phylogenetic relstionship of the genera and specles of herons.

The study is based upon 326 skeletons, representing twenty-one genera, forty species, and three additional subspecies.

Measurements of the major elements of the skeleton are given. The coeffielents of variation are relativily low (averaging 3.85 per cent) compared to those exhibited by other classes of vertebrates. Ratios between skeletal elenents also have a low coefficient of variation, sveraging 3.25 per cent. Although there is some seculal dimorphiam in linear neasurements, males being slightly larger, no sexual dimorphism is shown In the ratios constructed from these messurements.

On the basis of differences shown in the conformation and configuration of the varlous skelotal elements, the interrelationships between the species and geners are treced. The fan11y Ardeidee Includes three subsanilies, the Ardeinae or herons, the Cochlearlinae or bostbilled heron (heretofore treated as a separate fanily), and the Boteurinae or bitterns.

The subfanily Ardeinae is divided Into four tribes, all of which are new taxons. The tribe Ardeae or typical herons contains the genera Ardes, Hydranasse, Butorides, and Ardeols. The tribe Egrettac or egrets Includes the geners Camerodius, Beretta, Bubulous, and Florida. The 


\section{5}

tribe Nycticoraces or night herons includes the genera Dichromanassa, P1lherodius, Syrigma, Nyctanassa, Gorsachius, Nreticorax, and Peythrocmas. The tribe Tigriornithes or tiger bitterns is comprised of the genera Tigriornts and Tigrisoma." The osteological condition in the subfamilles and tribes is lllustrated by photographs.

For each genus the ostoological charactera are described, and mensural date and ratios are given.

The IIndts of the monotypic genus Florids are extended to include Leucophoys, so that the nane of the snowy egret becomes Florids thula.

The great white heron is considered a subspecies of the great blue herons, so that the name of the former becomes Ardea herodias occidentalis.

The North American green heron is treated as a subspecies of the South American and O1d World green-backed heron, under the name Butorides striatus virescens.

A phylogenetic tree of the various taxcons is presented. 


\section{LTPERATUER CITED}

Adans, C. T. 2955. Comparative osteology of the night herons. Condor, $57(1): 55-60$.

Arvey, 1. D. 1951. Phylogeny of the raxings and allied birds. InIverw sity of Kansas Publ. Mus. Nat. Hist., 3(3):473-530.

Bader, R. S. 1955. Varlability and evolutionary rate in the oreodonts. Bvolution, 9(2): 119-140.

Baume1, J. J. 1950. Comparative osteology of the 11 sh and the comnon crow. Univereity of Florida. Unpublished thesis, 1-73.

1953a. Individual variation in the white-necked raven. Condor, 55(1):26-32.

1953b. Comparative osteology of the genus Corvis. Unpublished thesis, 1-115. University of Morida.

Bent, A. C. 1904. Hotes on the herons nesting in Florida. Auk, 21(1): $20-29,259-270$.

1926. Ife history of the wading birds. U. S. Nat. Mus., BuI1. $135: 72-218$.

Berger, A. J. 1952. Comparative runctional morphology of the pelvie appendages of three genere of Cuculidee. Aner. Midl. Nat., $47(3): 513-605$.

Coues, E. 1927. Key to North Ameriean birds. 6th ed. Boston, The Page Co., vol. 1 and vol. 2.

Fngels, W. L. 1938. Varlation in bone lengths and 11mb proportions in the coot (Fuica americana). Jour. Morph., 62(3):599=607.

Fohon, J. H. 2952. The conparative osteology of the king and clepper ra11s. Unpublished thesis, 1-73. Univereity of Morida.

Flsher, H. I. 2946. Adaptations and comparative anatory of the 10c0motor apparatus of the new world vultures. Amer. Mldl. Nat., $35(3): 545-727$.

1947. The skelotons of recent and fossil Gymoryps. Pactfic Science, 1(4):227-236.

Gadow, H. 1892. On the classification of blrds. Proc. Zool. Soc, of Iondon, 2892:229-256. 
Glatfeltex, A. E. 1950. Comparative osteology of the Florida fay and the blue Jay. Unpublished thesis, 1-89. University of IJorida.

Q1enny, $\mathbb{F}$. H. 1955. Modifications of pattern in the aortic arch system of birds and their phylogenetic significance. Proc. U. S. Nat. Mus., 10h:525-621.

Hellnayr, C, E. and B. Conover. 1948. Catalogue of birds of the Americas. Zool. Serries, Field. Nus. Nat. Hist., Vol. 13, pt. 1(2): 207-219.

Howard, H. 1929. The avifeune of Heryville Sholimound. Univ, of Callf. Publ. 2001., 32(2):301-394.

1930. A census of the Pleistocene birds of Rancho Ls Brea Fron the collections of the Ios Angeles Muserm. Condor, 32: B1-88.

1936. Further studies upon the birds of the Pleistocene of Rancho la Brea. Condor, 38:32-36.

Meyr, E. 1956. Is the great white heron a good species? Auk, 73(1): $71-77$.

- Murie, J. 1872. On the skeleton of Todus with remarks as to Its arreses. Proc. Zool. Soc. Iondon, 1872:664-672.

Nelson, G. I. 1954. Relationships of the avian family Fringlulidee. Unpublished thesis, 1-89. University of Florida.

Peters, J. I. 1931. Bluds of the world. Vol. 1. Cambridges harvard University Press,

Newton, A. 1896. Dictionary of birds, Iondon: Adam and Charles Black.

Rldgway, R. 1878. Studies of the American Herodiones. U. S. Geogr. and Ceol Survery of the Territorles. 1878:219-251.

Roberts, A. 1940. The birds of South Africa. Johannesburgs The Central News Agency Ltd.

Shufeldt, R. W. 1887. Nycticorax nycticorax naevius, anatomy and skaul Pigured. U. S. Nat. Wus. Proc. 1887:384-385.

1889. Osteological studies of the subfantly Ardesnae. Jour. Cormp. Med. and Surg,, 10(3):218-24,3; $20(4): 287-317$.

1899. Observations on the classifleation of birds. Ann. Nat. H1st., $7(4): 101-111$. 
Shufeldt, R. W. 2901. Osteologs of the Herodiones, Ann. Carnegle Mus., vo1. 1, 1901:158-2149. $130: 169-24,8$. 1909. Osteology of birds. Univ. N. I. State Mus. Bull., 1915. Foesil birds of the Marsh Collection of Yale University. Transactions of the Connecticut Acadency of Arts and Selences, 19:1-110.

Wetmore, A. 1920. The function of powder-downs in herons. Condior, 32: $168-170$.

2940. Checklist of fossil blrds of North Amerlca. Suiths. Kisel. Co11.; $99(4): 1$-81.

1951. Revised classifleation of birds of the vorid. Smiths. MEsel. Coll., $117(4): 1-22$. 
Table 1

Skeletal meesurenente (ma.)

Andes gumatrama

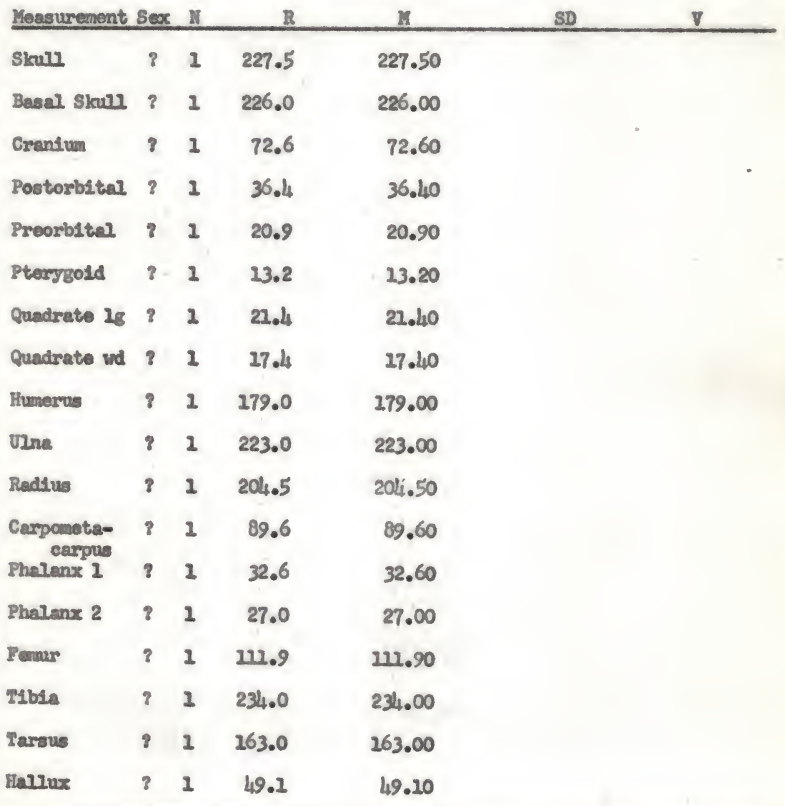


Table 1 (eont.)

Skelotal messurements (nos)

Ardes goliath

Meesurement Sex II R M

$S D$ v

\begin{tabular}{|c|c|c|c|c|}
\hline Skoull & \& & 1 & 221.0 & 2214.0 \\
\hline Basal skull & 8 & 1 & 223.5 & 223.5 \\
\hline & 8 & & $222.0-238.5$ & $224 . \mathrm{C}$ \\
\hline Cranlum & & & 79. & \\
\hline Postorbital & 8 & & $\begin{array}{l}75 . \\
40 .\end{array}$ & \\
\hline reorbital & o & & 24. & \\
\hline & 8 & & & \\
\hline texygold & \% & & & \\
\hline Quadrate I8 & d & & & \\
\hline Quadrate wd & 8 & & & \\
\hline & 8 & & -22.4 & \\
\hline thamerus & 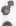 & 1 & 206. & 206 \\
\hline & 8 & & 193. & 201 \\
\hline Una & 8 & 2 & 221 & 232 \\
\hline Radius & 8 & & 224. & \\
\hline Garponete- & 8 & & $\begin{array}{l}210.5-8 \\
101.6\end{array}$ & 221. \\
\hline $\mathrm{cas}$ & 8 & 2 & $97.4-103.6$ & 100. \\
\hline Phalens 1 & 8 & & 39.4 & 39 \\
\hline Phelanx 2 & 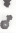 & & -38.0 & \\
\hline & 8 & & 32.8 & \\
\hline Pemur & \& & 2 & $116.9-129.0$ & 122 \\
\hline Tubia & 8 & 3 & $213.4-125.0$ & 119 \\
\hline & 8 & & $0-267.0$ & 257 \\
\hline Sarsus & 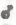 & & 189. & \\
\hline & & & 170. & 176 \\
\hline & 8 & & 52. & 55 \\
\hline
\end{tabular}


Table 1 (cont.)

Skeletal measurements (nm.)

Ardea melanocephals

Meesurement Sex N R M

Skuil

- $2154.0-155.0 \quad 154.50$

Basal Skunl \& $2 \quad 152.2-152.5152 .50$

Cranlum \& $2 \quad 57.7-59.6 \quad 58.70$

Postorbital $2 \quad 33.9-34.5 \quad 34.20$

Preorbital \& $2 \quad 17.4-17.5 \quad 17.45$

Pterygold \& $2 \quad 12.2-12.5 \quad 12.35$

Quedrate If $\& \quad 2 \quad 10.3-19.7 \quad 19.50$

Quadrate wd \& 2 25.4-15.7 15.55

Humeare of $2 \quad 156.0-157.5 \quad 156.75$

UIna \& $2 \quad 282.0-185.0 \quad 183.50$

Radius \& $2 \quad 175.0-178.5 \quad 176.50$

$\begin{array}{llll}\text { Carponete- } & 2 & 79.7-80.3 \quad 80.00\end{array}$ carpus

Phalanx 1 \& 2 25.9-28.4 27.15

Phalanx 2 \& $24.6-25.3 \quad 24.95$

Fenur $2 \quad 2 \quad 86.6-87.4 \quad 87.00$

$\begin{array}{llll}\text { Tibla } & 2 & 197.198 .5 & 197.75\end{array}$

Tarsus \& $2 \quad \nu_{13.5}-\nu_{4} 6.0 \quad \nu_{14.75}$

$\begin{array}{llll}\text { Hallux } & 2 \quad 33.8-36.2 \quad 35.00\end{array}$ 


\section{Table 2 (cont.)}

Skeletal measurements (m.)

\section{Ardes cineres}

\section{Measurement Sex N}

\section{Slaul1}

Basel Skun

Crantum

Postorbitel : 6

Preorbitel : 6

Pterygoid \& 6

quadrete is

Quedrate wd

Humerus

Une

Radín

Carpometecarpus

Phalanx 1

Phalanx 2

Teaur

Tible

Tarsas

HeIIwx
R

x

SD

$\nabla$

$180.42+1.29$

$3.15 \pm .91 \quad 1.76 \pm .51$

$168.5-178.0 \quad 173.25$

$173.0-180.0 \quad 177.50 \pm 1.29$

$166.0-177.0 \quad 171.50$

$61.5-66.0$

$64.17 \div .61$

65.70

$32.6-35.0$

$33.2-33.8$

$17.8-20.0$

$18.1-18.4$

$12.5-14.9$

12.9-13.7

$20.7-21.5$

$20.6-20.7$

$16.3-18.2$

25. $4-16.1$

$168.0-183.5 \quad 176.93+1.96$

$166.2-171.0$

$196.5-215.0$

196.5

$289.5-206.5$

190.0

$34.10 \pm .33$

33.50

$19.18 \pm .36$

18.05

$23.72 \pm .30$

13.30

$22.20 \pm .25$ 20.65

$26.80 \pm .25$

15.75

$3.16 \pm .91 \quad 1.76 \pm .51$

$1.49 \pm .43$

$2.32 \pm .67$

$0.82 \pm .24 \quad 2.40 \pm .69$

$0.87 \pm .25 \quad 4.54 \pm 1.32$

$0.74 \pm .21 \quad 5.39 \pm 1.56$

$0.37 \pm .21 \quad 1.75 \pm .51$

$0.61 \pm .18 \quad 3.63 \pm 1.05$

168.02

$208.58 \div 2.56$ 196.50

$5.20 \pm 1.392 .94 \pm .79$

$6.51 \pm 1.88 \quad 3.12 \pm .90$

$201.00+2.52$ 190.00

89.9-96.8

$90.5-93.0$

$31.8-34.9$

$29.7-33.0$

$27.2-29.0$

$25.7-29.6$

89.9-96.6

$83.7-89.3$

$186.0-216.5$

$190.5-224.0$

$93.93 \pm 1.09$

$6.28 \pm 1.79 \quad 3.07 \pm .89$

91.75

$33.12 \pm .40$

$2.67 \pm .77 \quad 2.84 \pm .92$

31.35

$28.23 \pm$. 31

27.65

$92.20 \div .72$

$86.23+1.34$

206.0074 .32

207.25

$135.0-165.0$

14.5-258.0

$33.4-38.4$

$33.4-38.4$
$154.78+4.24$

152.75

$35.95 \pm .66$

35.90
$0.98 \pm .28 \quad 2.96 \pm .86$

$0.75 \pm .22 \quad 2.66 \pm .77$

$2.01 \pm .50$

$2.68 \div .95$

$2.28+.55$

$3.21+1.10$

$5.214 \pm 1.49$

$10.59 \mp 3.06$

$10.40 \pm 3.01 \quad 6.72 \pm 1.94$

$1.61 \pm .41 \quad 4.48 \pm 1.29$ 
Table 1 (cont.)

Skeletal measurenente (man)

Ardea herodias treganzas

Neasurenent Sex N M SD v

\begin{tabular}{|c|c|c|c|c|c|c|}
\hline Slowe1 & 8 & $\begin{array}{l}4 \\
3\end{array}$ & $\begin{array}{l}200.5-221.5 \\
199.0-206.0\end{array}$ & $\begin{array}{l}213.50 \\
201.66\end{array} \pm 4.96$ & $9.92 \pm 3.51$ & $4.65 \pm 2.64$ \\
\hline Bessal Skwill & 8 & $\begin{array}{l}4 \\
3\end{array}$ & $\begin{array}{l}197.5-219.0 \\
196.5-203.5\end{array}$ & $210.88 \div 5.04$ & $20.07 \pm 3.56$ & $4.78 \pm 1.69$ \\
\hline Crantum & 8 & $\frac{4}{3}$ & $\begin{array}{l}67.6-73.6 \\
68.3-69.2\end{array}$ & $\begin{array}{l}71.93 \\
68.70\end{array}$ & $2.82 \pm 1.00$ & $3.92 \pm 1.39$ \\
\hline Postorbitel & i & 5 & $\begin{array}{l}34.6-37.3 \\
34.4-35.9\end{array}$ & $\frac{36.38}{35.30} \pm .47$ & $1.05 \pm .33$ & $2.89 \pm .81$ \\
\hline Preorbital & 8 & $\begin{array}{l}5 \\
3\end{array}$ & $\begin{array}{l}19.6-21.1 \\
19.0-19.8\end{array}$ & $20.42 \pm .29$ & $0.64 \pm .23$ & $3.13 \pm .99$ \\
\hline Pterygold & 8 & $\begin{array}{l}5 \\
3 \\
5\end{array}$ & $13.2-15.4$ & $\frac{u_{1} .50}{u_{1.17}} \pm .38$ & $0.85 \pm .27$ & $5.86 \pm 1.85$ \\
\hline Guadrate 28 & 8 & $\begin{array}{l}5 \\
3\end{array}$ & $\begin{array}{l}22.4-24.2 \\
22.0-22.5\end{array}$ & $\begin{array}{l}23.38 \\
22.23\end{array}$ & $0.76 \pm .24$ & $3.25 \pm 1.03$ \\
\hline Quadrate nd & 8 & $\begin{array}{l}5 \\
3\end{array}$ & $\begin{array}{l}17.7-19.8 \\
17.6-18.9\end{array}$ & $\frac{19.16}{18.23} \pm .38$ & $0.84 \pm .27$ & $4.38 \pm 2.39$ \\
\hline Humerus & 8 & $\frac{4}{2}$ & $\begin{array}{l}187.5-198.0 \\
183.50\end{array}$ & $\frac{194.38}{283.50} \pm 2.10$ & $4.70 \pm 1.49$ & $2.42 \pm .77$ \\
\hline Una & : & $\begin{array}{l}5 \\
3 \\
5\end{array}$ & $\begin{array}{l}213.0-236.0 \\
205.5-225.5\end{array}$ & $228.80 \pm 4.25$ & $9.30 \pm 2.34$ & $4.06 \pm 1.28$ \\
\hline Radius & : & $\begin{array}{l}5 \\
2 \\
5\end{array}$ & $\begin{array}{l}204.5-226.5 \\
209 \cdot 0-227.5\end{array}$ & $219.90 \pm 4.05$ & $9.07 \pm 2.87$ & $4.12 \pm 1.30$ \\
\hline Carpomete- & ? & $\begin{array}{l}5 \\
3\end{array}$ & $\begin{array}{l}95.8-106.9 \\
96.9-100.1\end{array}$ & $\begin{array}{r}102.86 \\
98.00\end{array}$ & $4.20 \pm 1.33$ & $4.08 \pm 1.29$ \\
\hline Phelanx 2 & 8 & $\begin{array}{l}4 \\
3\end{array}$ & $\begin{array}{l}36.0-39.3 \\
35.3-36.53\end{array}$ & $38.23 \pm .62$ & $1.24 \pm .446$ & $3.24 \pm 1.14$ \\
\hline Phalanx 2 & ? & $\begin{array}{l}5 \\
2\end{array}$ & $\begin{array}{l}29.5-33.2 \\
29.9-30.5\end{array}$ & $31.40 \pm .59$ & $1.33 \pm .42$ & $4.24 \pm 2.34$ \\
\hline Feumur & 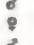 & $\frac{4}{3}$ & $98.3-106.5$ & $99.03 \pm 1.94$ & $3.88 \pm 1.37$ & $3.73 \pm 1.32$ \\
\hline Tibia & 8 & $\begin{array}{l}4 \\
3\end{array}$ & $\begin{array}{l}232.5-258.5 \\
227.5-2241.5\end{array}$ & $\begin{array}{l}248.25 \\
236.17\end{array}$ & $21.95 \pm 4.22$ & $4.81 \pm 1.70$ \\
\hline Targus & 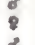 & $\begin{array}{l}4 \\
3 \\
5\end{array}$ & $174 \cdot 0-190.5$ & $184.38 \pm 3.55$ & $7.09 \pm 2.51$ & $3.85 \pm 2.36$ \\
\hline Hatex & 8 & $\begin{array}{l}5 \\
3\end{array}$ & $\begin{array}{l}40.9-47.0 \\
41.8-43.8\end{array}$ & $\frac{45.28}{43.03} \pm 1.13$ & $2.53 \pm .80$ & $5.60 \pm 1.77$ \\
\hline
\end{tabular}


Table I (cont.)

Skeletal measurements ( $\mathrm{mm}$.)

Ardea herodias herodias

\begin{tabular}{|c|c|c|c|c|c|c|}
\hline asuremen & & II & R & II & SD & $\boldsymbol{\nabla}$ \\
\hline uבI & $d$ & 28 & 293.5 & $209.22+1.58$ & $6.72+1.12$ & $3.21 \pm$ \\
\hline & 8 & य. & & $195.42 \pm 1.59$ & $5.95 \pm 1.12$ & \\
\hline Lal Skwul & & 18 & 191.5 & $206.47 \$ 1.68$ & $7.13 \mp 1.19$ & 3.45 \\
\hline & 8 & $u_{b}$ & $184.5-2014.5$ & $192.93+1.56$ & $5.84 \pm 1.20$ & 3.03 \\
\hline Crantuan & & 18 & $66.9-73.0$ & $71.05 \pm .37$ & $1.55 \pm .26$ & $2.18 \div$ \\
\hline storbital & & $\begin{array}{l}1 / 4 \\
17\end{array}$ & $34.3=3$ & $\begin{array}{l}68.01 \div .22 \\
36.06 \div .24\end{array}$ & $\begin{array}{l}0.84 \pm .16 \\
0.97 \div .17\end{array}$ & $\frac{1.24}{2.69} \div$ \\
\hline & & $\vec{u}_{4}$ & & $34.96 \div .25$ & $0.93 \div .18$ & \\
\hline eorbit tell & $\delta$ & 19 & $19.0-21.3$ & $20.11 \pm .14$ & $0.61 \pm .10$ & \\
\hline & & 13 & $18.3-20.0$ & $19.29 \pm .25$ & $0.54 \pm .21$ & \\
\hline exygoid & & 19 & $13.6-16.1$ & $25.27 \mp .48$ & $2.08 \pm .34$ & \\
\hline & & 13 & 13.7 & $14.18 \pm .13$ & $0.48 \pm .09$ & \\
\hline puedrate ig & & 19 & -24.9 & $23.04 \pm .19$ & $0.84 \pm$ & \\
\hline & & $\underline{y_{4}}$ & & $22.56 \pm .23$ & $0.85 \pm$ & \\
\hline Duadrate wd & & 19 & & $17.92 \pm .43$ & $1.89 \mp .31$ & 10.55 \\
\hline & & प्4 & 16.5 & $17.31 \pm .15$ & $0.57 \pm .07$ & \\
\hline Aumerus & & 18 & $188.0-200.5$ & $194.76 \pm .86$ & $3.66 \mp .61$ & \\
\hline na. & & $\frac{14}{19}$ & 17 & $\begin{array}{l}185.07 \div .98 \\
228.63 \div 7\end{array}$ & $3.66 \pm .69$ & $\begin{array}{l}1.98 \mp \\
2.54 \pm\end{array}$ \\
\hline & 8 & ü $_{4}$ & 28.0 & $218.88 \pm 2.08$ & $4.03 \div .76$ & $\begin{array}{l}2.34 \\
1.84 \pm .44\end{array}$ \\
\hline iedius & & 19 & 209 & $220.17 \pm 1.34$ & $5.05 \pm .95$ & $2.66 \div .44$ \\
\hline & & $\boldsymbol{I H}_{4}$ & 204.5 & 211.21 .11 .05 & & \\
\hline rpomota- & & 19 & 97.5 & $102.06 \pm .63$ & .45 & \\
\hline & & 14 & 93.5 & $98.02 \pm .61$ & & \\
\hline & & 19 & $\begin{array}{l}33.4 \\
31.3\end{array}$ & $\begin{array}{l}35.39 \div .38 \\
34.39 \div . .45\end{array}$ & $1.64 \mp .27$ & .75 \\
\hline hatanx 2 & \& & 19 & 28. & $30.65 \div .31$ & $1.35 \div .32$ & \\
\hline & & I4 & 27.3 & $28.84 \pm .28$ & & \\
\hline $\max$ & 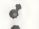 & 27 & 97.9 & $104.20 \pm .76$ & $3.13 \mp .54$ & \\
\hline & 8 & $\mathbf{2 4}$ & $94.5-101.0$ & & $1.98 \pm .37$ & \\
\hline$b$ & \& & 19 & $218.5-262.5$ & $248.61 \pm 2.46$ & $10.75 \pm 1.75$ & \\
\hline & ? & 13 & $219.5-251.0$ & $233.02 \mp 2.10$ & & \\
\hline 8 & $d$ & 19 & $163 \cdot 0-198.5$ & $183.76 \pm 1.96$ & & \\
\hline $11210 \times$ & 8 & 14 & $162.0-188.5$ & $172.41 \pm 1.86$ & & \\
\hline & & $\nu_{4}$ & $\begin{array}{l}40.9-49.44 \\
40.0-43.4\end{array}$ & $\begin{array}{l}44.58 \pm .49 \\
41.74 \div .28\end{array}$ & $\begin{array}{l}2.13 \pm .35 \\
1.04 \pm .20\end{array}$ & $\begin{array}{l}4.78 \div .78 \\
2.49 \div .47\end{array}$ \\
\hline
\end{tabular}


Table 1 (cont.)

Skeletel measurenents (mon)

\section{Andee occidentalis}

Measurement Sex $\mathrm{N}$

Sku11

? $2195.0-217.0 \quad 206.00$

Basal Sku1 ? $2 \quad 193.0-215.0 \quad 204.00$

$\begin{array}{llll}\text { Cranium } & 3 & 68.7-74.0 & 72.13\end{array}$

Postorbital ? $3 \quad 36.0-37.436 .90$

Preorbital ? $3 \quad 29.0-21.420 .17$

$\begin{array}{llll}\text { Pterygoid ? } 3 & 15.7-16.2 & 16.03\end{array}$

Quadrate $28 \quad ? \quad 3 \quad 22.2-24.5 \quad 23.47$

Qundrate wd ? $3 \quad 17.8-18.8 \quad 28.37$

$\begin{array}{llll}\text { Humerus } & 3 & 283.5-297.0 & 188.83\end{array}$

Uina ? $3214.5-226.0218 .83$

Radius ? $3 \quad 206.5-217.0 \quad 210.50$

Carponeta ? $396.4-100.998 .67$ cespus

Phalanse 1 ? $32.8-35.0 \quad 34.27$

Phatanx 2 ? $329.6-31.230 .57$

Fenur ? $3 \quad 102.2-108.0103 .43$

Tibia ? $3220.5-243.0228 .00$

$\begin{array}{lllll}\text { Tarsus } & ? & 3 & 159.5-186.5 & 173.17\end{array}$

$\begin{array}{llll}\text { Hallux } & 3 \quad 43.9-46.8 \quad 45.37\end{array}$ 


\section{6}

Table 1 (cont.)

Skolotal measurements (m.)

Andes cocol

Yeasurement Sex II

Skull

84

Besal Sloull ? 4

Granium ? 4

Postorbital ? 3

Preorbital ? 4

Pterggoid ? 4

Guadrate $2 g$ ? 3

Guadrate of ? 4

$\begin{array}{llll}\text { Hunerus } ? & 2 & 180.0-198.4 & 189.20\end{array}$

Una

? 3

211. $8-233.0 \quad 220.10$

Radius

$?$

Carponetacarpus

Phelanx 1

Phalanx 2

Femur

Tibia

Tarsus

Ballux

B

$35.0-36.9 \quad 35.97$

$20.1-24.6$

22.7-24.5 23.43

$3204.5-214.5 \quad 208.33$

? $392.0-97.295 .33$

$\begin{array}{llll}2 & 33.5-33.8 \quad 33.65\end{array}$

$\begin{array}{llll}3 & 3 & 28.5-33.9 & 31.13\end{array}$

12101.0

$104.5-107.5 \quad 106.00$

? $3 \quad 246.5-269.5 \quad 255.83$

? $3182.0-202.0191 .00$
$296.0-211.5205 .25 \pm 3.36$

$6.71 \pm 2.37 \quad 3.27 \pm 1.16$

$193.5-210.5203 .40 \pm 3.40$

$7.19 \pm 2.54 \quad 3.53 \pm 1.25$

$69.3-72.170 .43 \pm .49$

$0.97 \pm .34 \quad 1.38 \pm .49$

$21.75 \pm 2.03$

$2.06 \pm .73 \quad 9.47 \pm 3.35$

$\nu_{4.3-1 / 4.9} 1_{4.55} \pm .13$

$0.26 \pm .09 \quad 1.79 \pm .63$

$17.5-18.5 \quad 18.15 \pm .23$

$0.45 \pm .26 \quad 2.48 \pm .88$

$\begin{array}{llll}8 & 3 & 45.0-47.5 \quad 46.63\end{array}$ 
Table 1 (cont.)

Skeletal measurements (ma.)

Andea pacifica

Measurement Sex II

$M$

SD

v

$\begin{array}{lllll}\text { Skail } & 1 & 131.5 & 131.50\end{array}$

Besal skull ? $12129.5 \quad 129.50$

Cranive ? $2 \quad 50.9-52.8 \quad 51.40$

Postorb1tal ? 2 27.5-27.7 27.60

Preorbital ? 2 IH.0-IH.7 Hi.40

Pterygoid ? 2 20.9-12.0 22.00

Quadrate ig $8 \quad 2 \quad 25.1-15.6 \quad 25.35$

Quadrate wd ? $2 \quad 22.8-13.2 \quad 13.00$

$\begin{array}{lllll}\text { Finnervas } & 2 & 136.0-I_{4} 9.5 & \nu_{4} 2.75\end{array}$

Una $8 \quad 2 \quad 162.0-174.5 \quad 168.25$

Radius ? $2 \quad 255.0-168.5 \quad 161.75$

Carpomete- ? $2 \quad 76.4-84.9 \quad 80.65$ carpus

$\begin{array}{llll}\text { Phalanx } 2 \quad 23.0-30.7 & 29.35\end{array}$

Phalanx 2 ? 2 25.0-26.3 25.65

Feraur ? $2 \quad 66.7-72.2 \quad 69.45$

T1bia ? $2 \quad 150.5-167.5 \quad 159.00$

$\begin{array}{llll}\text { Tarsus } & 31.2-33.9 & 32.55\end{array}$

$\begin{array}{llll}\text { मอบ1 } & 2 \quad 24.5-24.6 \quad 24.65\end{array}$ 
Table 1 (cont.)

Skeletel measurements (ma.)

Ardes puspures

Measurement Sex H R M SD $v$

Skwar

o $1267.5 \quad 167.50$

Basal Skull of 1167.0 167.00

Crantium $\begin{array}{ll}4 \\ 8 & 2\end{array}$

Postorbital

Freorbltal $\therefore 4$ \& 2 Ptergroid of 4 Quadrate 18 Quadrate wd Hiumerus UIna

Radius Carponetacarrous

Phalanx 2

Phalanx 2 \& 2

$\begin{array}{lll} & 6 \\ & 8 & 4\end{array}$

Fenur

Inia

Tarsue

Hallus

\begin{tabular}{|c|c|c|c|}
\hline $\begin{array}{l}55.7-60.1 \\
52.8-54.7\end{array}$ & $\begin{array}{l}57.60 \\
53.75\end{array} \pm .96$ & $1.92 \pm .68$ & $3.33 \pm 1.18$ \\
\hline $\begin{array}{l}24.8-25.9 \\
24.5-24.6\end{array}$ & $\begin{array}{l}25.43 \\
24.55\end{array}$ & $0.22 \pm .08$ & $0.87 \pm .31$ \\
\hline $\begin{array}{l}14.4-16.0 \\
14.0-15.0\end{array}$ & $\begin{array}{l}15.40 \pm .38 \\
14.50\end{array}$ & $0.75 \pm .27$ & $4.87 \pm 1.72$ \\
\hline $\begin{array}{l}11.1-12.1 \\
10.5-10.8 \\
17.3-18.5 \\
16.6-16.8 \\
13.4-14.3 \\
13.3-13.5\end{array}$ & $\begin{array}{l}11.68 \pm .16 \\
10.65 \\
17.70 \\
26.70 \\
13.97 \\
13.40\end{array}$ & $0.32 \pm .12$ & $2.74 \pm .97$ \\
\hline $\begin{array}{l}137.5-145.5 \\
127.5-131.5\end{array}$ & $\frac{211.13}{129.50} \pm 1.58$ & $3.15 \pm 1.11$ & $2.23 \pm .79$ \\
\hline $\begin{array}{l}156.0-171.5 \\
11,6.0\end{array}$ & $\begin{array}{l}163.88 \\
W_{4} 6.00\end{array} \pm 3.73$ & $7.46 \pm 2.64$ & $4.55 \pm 1.61$ \\
\hline $150.5-161.0$ & $\begin{array}{l}157.25 \\
140.50\end{array}$ & $6.89 \pm 2.43$ & $4.38 \pm 1.55$ \\
\hline $\begin{array}{l}71.3-78.0 \\
67.7-69.9\end{array}$ & $75.30 \pm 1.43$ & $2.86 \pm 1.01$ & $3.80 \pm 1.34$ \\
\hline $\begin{array}{l}26.2-27.3 \\
24.0-24.6\end{array}$ & $26.83 \pm .12$ & $0.24 \pm .08$ & $8.95 \pm 3.16$ \\
\hline $\begin{array}{l}18.9-25.4 \\
15.6\end{array}$ & $\begin{array}{l}21.75 \pm 1.35 \\
19.60\end{array}$ & $2.69 \pm .95$ & $12.37 \pm 4.37$ \\
\hline $\begin{array}{r}90.4-94.6 \\
83.4-85.5\end{array}$ & $92.08 \pm .81$ & $2.62 \pm .57$ & $2.76 \pm .62$ \\
\hline $161 \cdot 0-191 \cdot 0$ & $\frac{174.50}{264.50} \pm 7.09$ & $14.18 \pm 5.01$ & $8.13 \pm 2.87$ \\
\hline $109.0-128.5$ & $\frac{124.50 \pm 2.44}{213.50}$ & $4.88 \pm 1.72$ & $3.92 \pm 1.39$ \\
\hline $\begin{array}{l}43.00447 .4 \\
42.7-44.04\end{array}$ & $\begin{array}{l}46.40 \pm .39 \\
43.55\end{array}$ & $0.78 \pm .28$ & $1.68 \pm .59$ \\
\hline
\end{tabular}


Table 1 (cont.)

Skeletal measurements (nan.)

P1iherodius p1leatus

Measurement Sex I M

SD

V

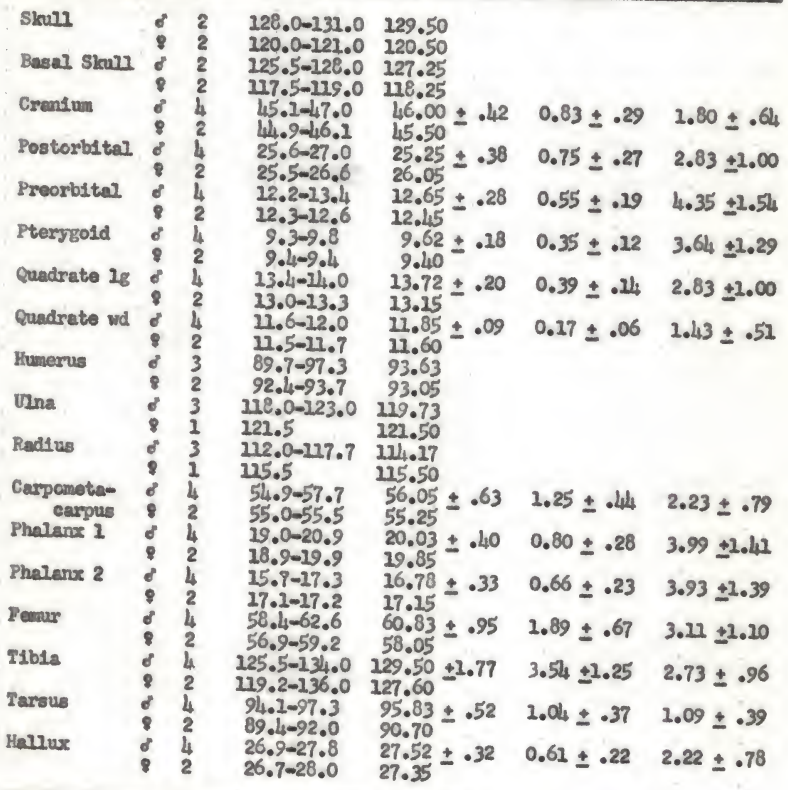


Fable 1 (cont.)

Skceletel measurenents (nins)

Butorides Virescens virescens

Moasurement Ser IV n

SD

V

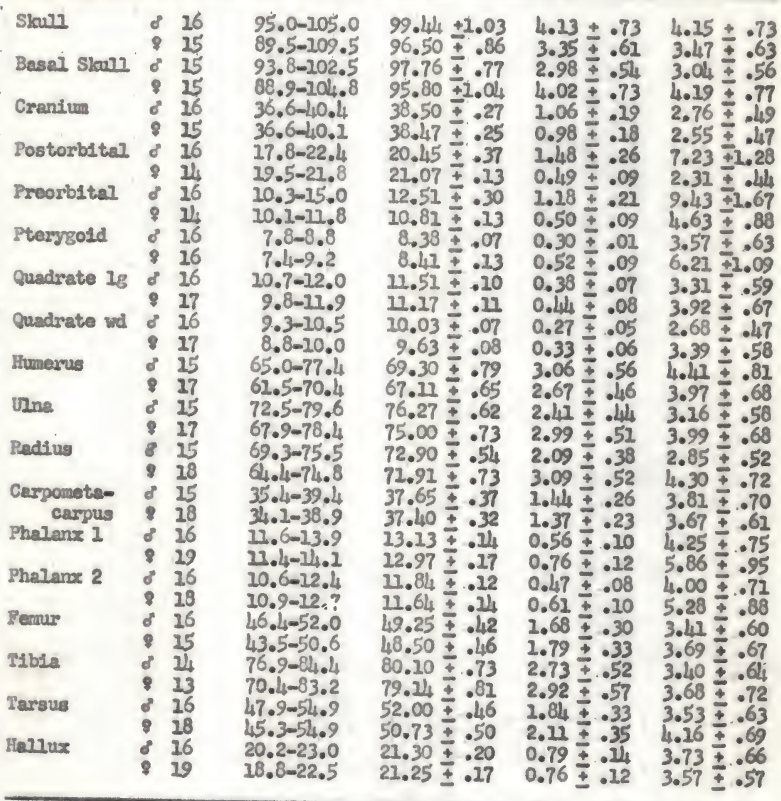


Table I (cont.)

Skeletal mossuranents (mi.)

Butorides striatus

Measurement Sex If s.

n

SD

$\nabla$

Sloulz

\& $2100.6 \quad 100.60$

Besal Skull

$\begin{array}{lll}8 & 96.9-104.7 \quad 99.77\end{array}$

1100.2

$\begin{array}{llllll}2 & 96.0-96.7 & 96.35\end{array}$

$\begin{array}{llll}\text { Cranive \& } & 1 & 37.5 & 37.50\end{array}$

Postorbdtel ? $3 \quad 37.5-39.5 \quad 38.33$

Postorbital $2121.1 \quad 210$

$20.3-21.220 .80$

$\begin{array}{llll}3 & 10.7-21.5 & 21.10\end{array}$

$\begin{array}{llll}\text { Ptarygoid } 9 & 9 & 9.0 & 9.00\end{array}$

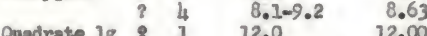

Quadrate $\mathrm{Ig} \quad \mathrm{I} \quad 12.0 \quad 12.00$

mate $3 \quad 11.3-12.0 \quad 11.60$

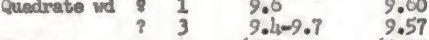

Humerus \& $1 \quad 69.0 \quad 69.00$

$\begin{array}{llll}? & 3 & 65.6-70.8 & 67.67\end{array}$

UIna \& $1 \quad 76.0 \quad 76.00$

$\begin{array}{llll} & 3 & 71.9-77.0 & 73.77\end{array}$

$\begin{array}{llll}2 & 3 & 68.4-74.1 & 70.63\end{array}$

Carponete- $137.6 \quad 37.60$

carpus ? $3 \quad 35.8 \mathrm{~m} 36.5 \quad 36.13$

Pholanx 1 \& 1 12.5 12.50

$\begin{array}{llll} & 3 & 13.0-13.7 & 13.23\end{array}$

Phelanx 2 \& 1 11.1 11.10

? $3 \quad 11.3-11.6 \quad 11.50$

$\begin{array}{lllll}\text { Fenur } & 8 & 1 & 48.9 & 48.90\end{array}$

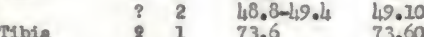

Irbia $173.6 \quad 73.60$

\begin{tabular}{lllllll} 
& $?$ & 4 & $75.0-79.0$ & $76.80 \pm .89$ & $1.77 \pm .63$ & $2.30 \pm .81$ \\
Tersus & 8 & 2 & 48.3 & $48.30 \pm .814$ & $1.67 \pm .59$ & $3.38 \pm 1.19$ \\
\multirow{3}{*}{ Harlux } & $?$ & 4 & $47.7-51.3$ & $49.35 \pm .84$ & $19 \pm 0.20$ \\
& 8 & 1 & 19.2 & $19.20 \pm .29$ & $0.57 \pm .20$ & $2.72 \pm .96$
\end{tabular}


Table I (cont.)

Siceletol measurements (mon.)

Exythocnus mufiventris

Measurement Sex N n

SD $\nabla$

Skoun

$\begin{array}{lll}? \quad & 92.4-97.6 \quad 95.23\end{array}$

Basal slower.

Crantun ? $3 \quad 37.7-40.3 \quad 38.93$

Postorbital ? 3 20.5-21.7 21.20

Preorbital ? $3 \quad 11.1-12.0 \quad 11.40$

$\begin{array}{lllll}\text { Pterygold } & 3 & 7.7-9.1 & 8.33\end{array}$

Quadrate 18 ? $3 \quad 21.0-12.5 \quad 12.83$

Quadrate wd ? $3 \quad 9.3-10.3 \quad 9.87$

$\begin{array}{llll}\text { flumerus } & 3 & 74.7-82.4 & 77.63\end{array}$

$\begin{array}{lllll}\text { Una } & 2 & 83.6-92.2 & 87.90\end{array}$

$\begin{array}{lllll}\text { Redius } \quad 2 & 79.9-87.3 \quad 83.60\end{array}$

Carponeter- ? $2 \quad 42.3-46.7 \quad$ 4h.20 carpus

Pholanx 2 ? $3 \quad \Psi_{4.7-15.6} 25.07$

$\begin{array}{lllll}\text { Phalanx } 2 \quad \text { ? } & 3 & 13.1-14.3 & 13.83\end{array}$

$\begin{array}{llll}\text { Femure } & 3 & 51.7-57.5 & 53.97\end{array}$

$\begin{array}{llll}\text { Tibla } & 3 & 83.9-89.8 & 86.03\end{array}$

$\begin{array}{llll}\text { Tareus } & 3 & 53.2-58.1 & 55.23\end{array}$

Hellux ? $3 \quad 20.5-21.9 \quad 21.13$ 
Table 1 (cont.)

Skeletal nessurenents (mon)

Floride caervilea

Measurement Sex II I

SD

V

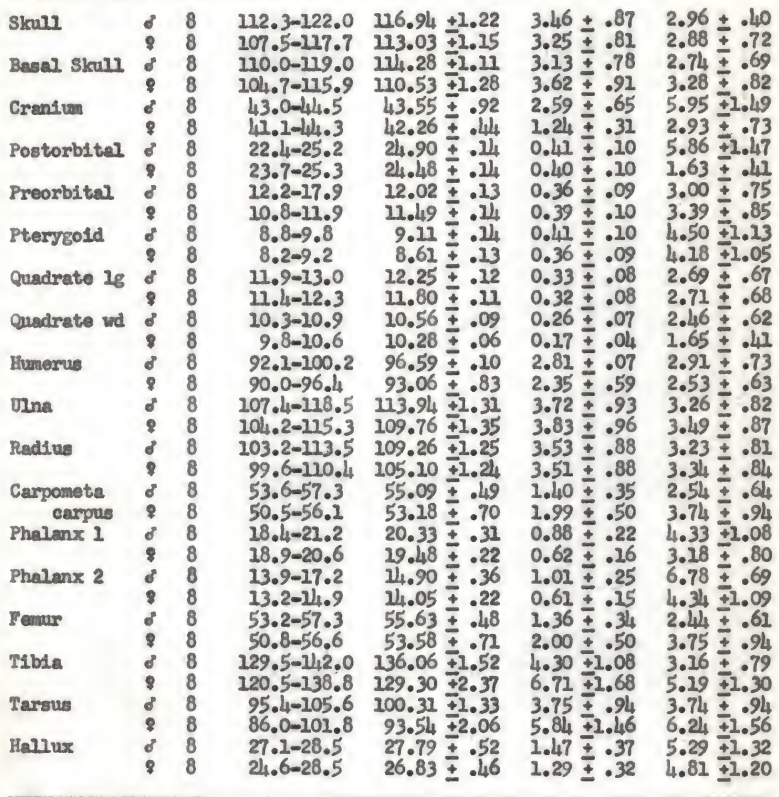


84

Table 1 (cont.)

Skeletal measurements (man.)

Ardeola ralloides

Measurement Sex N

R

M

SD

V

Starly ? $2 \quad 100.7-107.4 \quad 104.40$

Basel Skrul ? $2 \quad 100.0-107.0 \quad 103.50$

$\begin{array}{lllll}\text { Craniua } & ? & 2 & 38.3-39.4 & 38.90\end{array}$

Postorbital ? 2 20.8-21.6 20.25

Preorbital ? $2 \quad 10.8-11.5 \quad 11.20$

$\begin{array}{lllll}\text { Pterygold ? } 2 & 8.1-9.5 & 8.80\end{array}$

Quadrate 18 ? $2 \quad 11.3-11.4 \quad 11.35$

Quadrate wd ? $29.6-9.7 \quad 9.65$

$\begin{array}{lllll}\text { Humerus } & ? & 2 & 78.1-80.7 & 79.40\end{array}$

$\begin{array}{lllll}\text { une } \quad & 2 & 90.3-92.6 & 91.45\end{array}$

$\begin{array}{llll}\text { Radius } ? \quad 2 & 86.1-87.9 & 87.00\end{array}$

Carpometa- \& $2 \quad 43.0-44.7 \quad 43.85$ carpus

$\begin{array}{lllll}\text { Phalanx } 2 ~ & 2 & 14.9-16.5 & 15.70\end{array}$

Phalanx 2 ? 2 13.9-15.0 14.45

Fenur $\quad ? 251.0-54.0 \quad 52.50$

Tibla ? $291.7-93.0 \quad 92.35$

$\begin{array}{llll}\text { Tarsus } & 2 & 59.5-59.6 & 59.55\end{array}$

$\begin{array}{llll}\text { Ha.llux } & 2 & 21.3-24.2 & 22.75\end{array}$ 
Table 1 (cont.)

Skeletal measurements (men.)

Ardeole bacchus

Measurement Sex A

Skrure

Basel skunz

Crarifur

Postorbital

Preorbital

? I

Pterygoid \& 1

Quadrate 28

Quadrate wd

Humerus

Une

Radius

Caryometacarpus

Phalanx 1

Phatanx 2

Fenure

Tibin

Tarsus

Hallux
$\mathrm{R}$

M

95.50

95.50

94.50

94.80

36.90

39.30

21. 40

21.30

11.50

21. 60

7.90

10.90

12.30

9.40

10.00

74.10

77.30

87.30

88.30

82.60

42.00

45.80

14.60

15.20

14.40

15.50

49.40

53.10

85.50

88.40

57.20

54.70

21.00

21.50 
Table 1 (cont.)

Skeletal measurenents (men.)

Ardeola speciosa

\begin{tabular}{|c|c|c|c|c|c|c|}
\hline Yeasurement & Sex & I & $\mathrm{R}$ & M & SD & $\nabla$ \\
\hline Slaw27 & $\delta$ & 1 & 94.3 & 94.30 & & \\
\hline Basel Skrull & 8 & 2 & 93.5 & 93.50 & & \\
\hline Crentum & 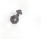 & 1 & 36.6 & 36.60 & & \\
\hline Postorbital & 8 & 1 & 21.4 & 21.40 & & \\
\hline Proorbital & 6 & 1 & 10.6 & 10.60 & & \\
\hline Pterygoid & ' & 1 & 7.7 & 7.70 & & \\
\hline Quadrate 28 & 8 & 1 & 11.7 & 11.70 & & \\
\hline Quadrate wd & 6 & 1 & 9.6 & 9.60 & & \\
\hline Humerus & 8 & 1 & 74.4 & 74.40 & & \\
\hline UIna & 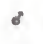 & 2 & 82.6 & 82.60 & & \\
\hline Redius & $\&$ & 1 & 77.9 & 77.90 & & \\
\hline $\begin{array}{l}\text { Carpometer } \\
\text { carpus }\end{array}$ & d & 1 & 40.0 & 40.00 & & \\
\hline Phatonx 1 & 8 & 2 & 24.3 & $u_{4.30}$ & & \\
\hline Phalanx 2 & 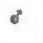 & 1 & 4.2 & 14.20 & & \\
\hline Femar & 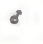 & 1 & 51.3 & 51.30 & & \\
\hline Tibia & 8 & 1 & 67.9 & 67.90 & & \\
\hline Tarsus & 8 & 1 & 58.8 & 58.80 & & \\
\hline HaIIux & $d$ & 1 & 23.0 & 23.00 & & \\
\hline
\end{tabular}


Table 1 (cont,)

Skeletal measurements (w..)

Bubuleus 1bis

Measurement Sex II

Skwur

Basul skull

Cranium

Postorbital \& 5

Preorbital

Pterygoid

Quadrate 18

Quedrate wd

Flumerus

una

Radius

Carponetaearpus

Phalanx 2

Pharanx 2

Fenurer

Tibla

Tarsus

Harlux

จ 5

\& 1

\& $\frac{1}{5}$

85

. 5

81

$\circ 1$

84

- 1

24

81

-4

d 1

\& 4

- 1

- 4

(.) 1

85

\& 3

- 4

$\therefore 1$

84
- 195.395 .30

\& $492.4-102.696 .48$

$38.9-40.9 \quad 39.86 \pm .33$

$4.27+1.51$

$0.75 \pm .24 \quad 1.88 \pm .59$

$23.0-24.6$

$23.86 \pm .35$

$0.78 \pm .25 \quad 3.27 \pm 1.03$

8 1

\& 1
$11,0 \quad 11,00$

$10.2-11.6 \quad 10.92$

8.4

12.7

11. 2-12.1

11,0

10.0-10.8

91.9

105.2

105.20

$99.3-104.6102 .13 \pm 1.02$

100.90

95.3-100.9

48.5

$98.10 \pm 1.15$

48.50

$8.70+.18$

12.70

$11.66 \pm .16$

11.00

$10.46 \pm .13$

91.90

$88.20+1.00$

西

$45.7-48.1$

18.3

$46.78 \pm .41$

18.30

17.4-18.9

17.2

$17.83 \pm .38$

17.20

$16.2-16.6$

53.2

$49.4-56.0$

112.7

106.7-123.

80.1

$76.8-87.2$

25.7

$24.2-27.9$
$85.6-39.9$
$16.37 \pm .20$

53,20

$52.88+1.36$

112.70

$112.02+3.89$

80.10

$79.53 \pm 2.54$

25.70

$25.75 \pm .80$
$0.62 \pm .20 \quad 5.68 \pm 1.80$

$0.42 \pm .13 \quad 4.71 \pm 1.49$

$0.36 \pm .11 \quad 3.09 \pm .98$

$0.30 \pm .09 \quad 2.87 \pm .91$

$1.99 \pm .70 \quad 2.26 \pm .80$

$2.04 \pm .72 \quad 2.00 \pm .71$

$2.29 \pm .81 \quad 2.33 \pm .82$

$0.82 \pm .29 \quad 1.75 \pm .62$

$0.75 \pm .27 \quad 4.21 \pm 1.49$

$0.39 \pm .14 \quad 2.38 \pm .84$

$3.04 \pm .96 \quad 5.75 \pm 1.82$

$7.78 \pm 2.75 \quad 6.95 \pm 2.46$

$5.07 \pm 1.79 \quad 6.37 \pm 2.25$

$1.60 \pm .57 \quad 6.21 \pm 2.19$ 
Table 1 (cont.)

Skeletal, measurements (ma.)

Dichromenassa rufescens

Measurement Sex N M

$S D$

v

Skuzl

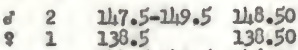

Basal Skuz

Bamal shall

8. 2 1.4.5-147.5 $1,6.00$

$\begin{array}{llll}\text { Cranium \& } & 1 & 135.5 & 135.50 \\ & \text { \& } & 50.4-52.3 & 51.5 ?\end{array}$

Postorbital

$8 \quad 2 \quad 49.9-52.0$

\& 2

28.1-31.0

$27.9-30.5$

$14.0-15.2$

$13.6-114.5$

50.95

29.60

29.20

Preorbital of 3

Pterygoid of $2 \quad 10.7-10.7 \quad 10.70$

$\begin{array}{llll}2 & 10.2-10.8 & 10.50\end{array}$

Quadrate Ig of $3 \quad 14.6-14.8 \quad 14.70$

\& $2 \quad 13.9-114.7 \quad \frac{11}{4} .30$

Quadrate wd \& 3 12.2-12.6 12.47

$11.9-12.7 \quad 12.30$

Hunerus o $3 \quad 118.5-125.5 \quad 122.83$

\& $2 \quad 125.5-128.5 \quad 122.00$

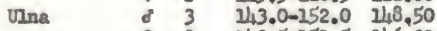

( 2 I $10.5-151.5 \quad \nu_{4} 6,00$

Radius $2 \quad 137.5-11,6.5 \quad 11_{4} 2,00$

i 2 135.0-1 $15.0 \quad \nu_{14} 0.50$

Carponete- is 3 69.8-73.3 71.77 carpus \& 2 66.9-73.3 70,10

Phalanx 1 \& 3 23.3-24.6 23.87

$222.3-24,9 \quad 23.60$

Pholanx 2 \& 3 20,2-21.3 20,90

\& $2 \quad 20.2-20.3 \quad 20.25$

Femur of 2 67.3-72.0 69.25

\& $2 \quad 65.0-71.4 \quad 68.20$

Tibia o $3 \quad 161,0-184.9 \quad 173,47$

\& $2 \quad 173.0-173,0 \quad 175.50$

Tarsus of $3 \quad 127.0-151.0 \quad 138.00$

Hallux \& 1 ע.5.5

Hallux \& 3 26.7-29.0 27.73 


\section{Tabie 1 (cont.)}

Skeletal measurements (rma)

Casmerodius albus modestus

\begin{tabular}{|c|c|c|c|c|c|c|}
\hline Measurenent & $\operatorname{sex}$ & III & $\mathbf{R}$ & $\mathrm{H}$ & SD & $\nabla$ \\
\hline Skan23 & 8 & 1 & 153.0 & 253.00 & & \\
\hline Basal skwil & 8 & 1 & 251.0 & 151.00 & & \\
\hline Crantuan & 8 & 1 & 51.9 & 51.90 & & \\
\hline Postorb1tal & 8 & 1 & 25.1 & 25.10 & & \\
\hline Preorbital & 8 & 1 & 13.4 & 23.40 & & \\
\hline Pterygold & 8 & 1 & 9.4 & 9.40 & & \\
\hline Quadrate If & 8 & 2 & 16.1 & 16.10 & & \\
\hline Quadrate wd & 8 & 2 & 12.4 & 12.40 & & \\
\hline Hiunerres & 8 & 2 & 235.0 & 235.00 & & \\
\hline Ulna & 8 & 1 & 259.5 & 159.50 & & \\
\hline Radius & 8 & 1 & 253.5 & 253.50 & & \\
\hline Carpometa- & 8 & 1 & 71.3 & 72.30 & & \\
\hline Phalanx 1 & 8 & 1 & 26.3 & 26.30 & & \\
\hline Phalanx 2 & 8 & 1 & 24.6 & 24.60 & & \\
\hline Temur & 2 & 1 & 71.5 & 71.50 & & \\
\hline Tibla & 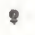 & 1 & 182.0 & 182.00 & & \\
\hline Tarsus & 8 & 1 & 141.5 & $u_{41.50}$ & & \\
\hline Hallux & 8 & 1 & 34.3 & 34.30 & & \\
\hline
\end{tabular}


Table I (cont.)

Skeletal measurements (ma.)

Casmerodius albus egretta

Measurement Sex II M

$S D$

v

\begin{tabular}{|c|c|c|c|c|c|c|}
\hline Slower & - & 12 & $258.0-177.5$ & $169.87 \pm 1.52$ & $5.04 \pm 1.08$ & $2.97 \pm .63$ \\
\hline & ? & 9 & $155.0-173.5$ & $165.89 \pm 2.65$ & $4.95 \div 1.17$ & $2.98 \div$ \\
\hline Besal Slaul2 & \& & 11 & $155.0-175.0$ & $168.23 \pm 1.34$ & $4.45 \mp .95$ & 2.65 \\
\hline & 9 & 9 & $252.5-171.3$ & $162.94 \$ 1.83$ & $5.50 \mp 1.30$ & 3.37 \\
\hline Cranfum & ? & $\frac{11}{9}$ & $\begin{array}{l}53.1-58.7 \\
53.1=58.9\end{array}$ & $56.66 \div .48$ & $1.58 \div \cdot 344$ & $2.79 \div$ \\
\hline Postorbital & $\sigma^{\prime \prime}$ & นี. & $23.9-26.3$ & $21.96 \div .24$ & $0.78 \div .17$ & $3.13 \div$ \\
\hline & 8 & 9 & $25.1-25.0$ & $24.66 \mp$ & $0.39 \mp .09$ & \\
\hline Preorbital & 8 & 21 & $12.8-15.1$ & If.23 & $0.62 \pm$ & 4.34 \\
\hline & 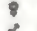 & 9 & $13.0-15.4$ & $v_{1} .57 \pm .24$ & $0.72 \pm$ & $4.93 \pm$ \\
\hline Pterysoid & \& & II & $9.6-11.2$ & $10.67 \pm .12$ & $0.39 \pm$ & $3.62 \pm$ \\
\hline Quadrate Ig & 8 & 9 & $9.8-11.2$ & $10.47 \div$ & $0.42 \div$ & 3.97 \\
\hline & 8 & $\frac{11}{9}$ & $\frac{15 \cdot 5-17.1}{15.5-17.5}$ & $\begin{array}{l}16.49 \div .17 \\
16.19 \div .22\end{array}$ & $\begin{array}{l}0.57 \div .12 \\
0.66 \div .16\end{array}$ & $3.45 \div$ \\
\hline Cuedrate wd & $\therefore$ & 11 & $12.3-13.6$ & $12.95 \pm .10$ & $0.34 \pm .07$ & 2.614 \\
\hline & $?$ & 9 & $22.1-14,4$ & $12.78 \pm .214$ & $0.71 \pm$ & 30 \\
\hline Hurearus & 8 & 1119 & $y_{10} 0.5-158.5$ & $150.69+1.26$ & $4.17 \div$ & 2.76 \\
\hline UIne & 8 & -9 & $177.5-191.0$ & $282.32+1.57$ & $4.71+1.21$ & 2.59 \\
\hline & 8 & 9 & $262.5-187.5$ & $173.61 \mp 2.46$ & $7.37 \mp 1.74$ & $4.25 \div$ \\
\hline Redius & \& & 21 & $162.0-184.0$ & $174.96 \pm 1.50$ & $4.98 \mp 1.06$ & $2.85 \%$ \\
\hline & & 9 & $156.5-179.5$ & $167.50 \mp 2.22$ & 6.67 & \\
\hline Garpometas & $\therefore$ & 11 & $73.3-86.3$ & $80.23 \mp .98$ & $3.25 \div .69$ & 4.05 \\
\hline Phalanx I & 8 & 11 & $\begin{array}{l}72.9-83.6 \\
25.4-29.9\end{array}$ & $\begin{array}{l}77.25 \pm 1.40 \\
28.00 \pm .39\end{array}$ & $1.28 \div .27$ & $3.127 \pm$ \\
\hline & ? & 9 & $25.9-29.3$ & $27.06 \pm .04$ & $3.92 \mp .45$ & $7.09 \div$ \\
\hline Phatenx 2 & $\&$ & 11 & $22.8-27.2$ & $25.10 \pm .32$ & $1.04 \mp \pm .22$ & $4.26 \overline{4}$ \\
\hline Perwar & & & $22.7-$ & $23 . ?$ & 1.89 & \\
\hline tonst & 8 & 10 & $\begin{array}{l}74.7-60.5 \\
72.6-85.3\end{array}$ & $82.05 \div .93$ & $\begin{array}{l}3.09 \div .66 \\
4.46 \div 1.00\end{array}$ & $5.76 \mp 1.29$ \\
\hline Tibla & $\delta$ & II & $193.0-226.5$ & $213.69+2.08$ & $6.91 \$ 1.47$ & 3.24 \\
\hline & & & $181.0-232.5$ & $206.25 \pm 4.40$ & 12.4443 .11 & \\
\hline Tarsus & 8 & 211 & $139 \cdot 0-170.5$ & $262.36 \pm 2.38$ & $7.90 \pm 1.68$ & $4.87+1.04$ \\
\hline Hellux & 6 & 11 & $34.7-43.5$ & $\begin{array}{r}150.66 \pm 2.77 \\
38.42 \pm .60\end{array}$ & $\begin{array}{l}8.31 \pm 1.96 \\
1.99 \pm .43\end{array}$ & $5.19 \div 1.11$ \\
\hline & ? & 9 & $34.3-40.7$ & $36.42 \pm .70$ & $2.10 \pm .40$ & $5.75 \mathrm{~m}$ \\
\hline
\end{tabular}


Table 1 (cont.)

Skeletal measurements (mo)

Epretta garzetta

Meesurement Sex \&

Skoun

Basal Skull

Crantiun

Postorbital

\& 3

Preorbital

Pterygoid

83

Quedrate ig

Quadrate wd

Huservas

Una

Radius

Carponetecarpus

Phalanx 1

Phalanx 2

Fermar

Tibia

Texsus

Hallux
B

M

$S D$

234.90

211.99

117.80

117.90

171.9

21.8-117.3 216.05

40.3

41. $1-41.9$

22.7

$23.2-23.4$

21.0

11. $4-21.9$

8.3

$7.9-8.8$

11.3

17. $4-12.0$

9.8

$10.1-10.4$

93.7-99.4

$95.5-104.1$

107.2-131.

$123.6-126$.

103.5-125.5

$108.4-120.0$

$51.4-59.7$

$51.3-58.4$

28.9

18.7-20.

18.1

17.2-19.

$55.8-60.5$

$53.0-59.4$ 125.5-15i.5

123.5-157.5

83.0-103.3

92.1-110.4

$25.3-26.4$

24.1-26.9

40.30

41.50

22.70

23.30

11.00

21.70

8.30

8.33

11.30

11.70

9.80

10.23

96.55

ن19.10

218.03

115.00

112.63

55.55

53.77 18.90

19.47

18.10

17.93

58.63

135.50

140.50

93.15

99.23

25.85

25.10
$97.73 \pm 2.09 \quad 4.17 \pm 1.47 \quad 4.27 \pm 1.51$

$55.13 \pm 1.43 \quad 2.85 \pm 1.01 \quad 5.17 \pm 1.83$ 
Table 1 (cont.)

Skeletal measureswenta (mo)

Foretta Intermedia

\begin{tabular}{|c|c|c|c|c|c|c|}
\hline Meagurement & Sex & III & $\mathrm{R}$ & $M$ & SD & $\nabla$ \\
\hline Skunl & $\delta$ & 1 & 121.5 & 121.50 & & \\
\hline Besal Skull & 8 & 1 & 220.0 & 219.00 & & \\
\hline Cranium & o & 1 & 46.2 & 46.20 & & \\
\hline Postorbital & 8 & 1 & 25.3 & 25.30 & & \\
\hline Preorbital & \& & 2 & 13.1 & 13.10 & & \\
\hline Pterygold & 8 & 1 & 8.5 & 8.50 & & \\
\hline Guadrate Is & 8 & 1 & 13.3 & 13.30 & & \\
\hline Quadrate vd & 8 & 1 & 21.1 & 11.10 & & \\
\hline Humerus & $\delta$ & 1 & 213.5 & 213.50 & & \\
\hline Ulne & 8 & 1 & 236.5 & 136.50 & & \\
\hline Radius & d & 1 & 131.0 & 131.00 & & \\
\hline Carpometa- & d & 1 & 62.4 & 62.40 & & \\
\hline Phatanx 1 & $\sigma^{\circ}$ & 1 & 21.5 & 22.50 & & \\
\hline Phalanx 1 & \& & 1 & 19.1 & 19.10 & & \\
\hline Fermar & $d$ & 1 & 60.1 & 60.10 & & \\
\hline Tible & ' & 1 & 259.5 & 259.50 & & \\
\hline Tarsus & $d$ & 1 & 218.1 & 218.20 & & \\
\hline Hallux & $d$ & 1 & 32.8 & 32.80 & & \\
\hline
\end{tabular}


Table 1 (cont.)

Skeiotal, measurements (nm.)

Leucophove thuls

\begin{tabular}{|c|c|c|c|c|c|c|}
\hline easurement & & N & $\mathrm{R}$ & M & $S D$ & $v$ \\
\hline Skouns & 8 & $\begin{array}{l}9 \\
3\end{array}$ & $\begin{array}{l}106.7-124.5 \\
111.8-1 U_{4} .0\end{array}$ & $\frac{116.48}{113.10} \pm 1.88$ & $5.65 \pm 1.33$ & $4.85 \pm 1.24$ \\
\hline Besal Skunt & 8 & 9 & $\begin{array}{l}204.7-122.5 \\
109.4-217.8\end{array}$ & $\frac{173.82}{210.93} \pm 2.81$ & $5.42 \pm 1.28$ & $4.76 \pm 1.12$ \\
\hline Cranilum & 8 & 9 & $\begin{array}{l}40.0-42.5 \\
38.6-40.0\end{array}$ & $\frac{41.13}{39.40} \pm .32$ & $0.95 \pm .22$ & $2.31 \pm .52$ \\
\hline Postorbital & 8 & 9 & $\begin{array}{l}3.3-24.6 \\
3.1-23.6\end{array}$ & $\begin{array}{l}23.78 \\
23.40\end{array}=.12$ & $0.35 \pm .08$ & $1.47 \pm .35$ \\
\hline Preorbital & & 9 & $\begin{array}{l}10.9-12.3 \\
10.7-10.8\end{array}$ & $\frac{21.63}{10.73} \pm .16$ & $0.47 \pm .12$ & $4.04 \pm .95$ \\
\hline Pterygoid & 8 & $\begin{array}{l}9 \\
3\end{array}$ & $\begin{array}{l}7.7-9.7 \\
7.9-8.3\end{array}$ & $\begin{array}{l}8.78 \pm .17 \\
8.07\end{array}$ & $0.50 \pm .12$ & $5.69 \pm 1.34$ \\
\hline Quadrate $2 \mathrm{~g}$ & & 9 & $\frac{17.0-11.9}{20.8-11.0}$ & $\frac{17.47}{10.87} \pm .28$ & $0.85 \pm .20$ & $7.45 \pm 1.76$ \\
\hline Quadrate wd & & 9 & $\begin{array}{l}9.4-10.2 \\
9.3-9.4\end{array}$ & $\frac{9.84}{9.33} \pm .12$ & $0.33 \pm .08$ & $3.35 \pm .79$ \\
\hline Humerus & & 8 & $\begin{array}{l}92.0-101.8 \\
88.8-97.1\end{array}$ & $96.00 \pm .79$ & $2.24 \pm .56$ & $\begin{array}{l}2.33 \pm .58 \\
3.93 \pm 1.24\end{array}$ \\
\hline Uns & : & $\begin{array}{l}9 \\
3\end{array}$ & $\begin{array}{l}107.5-121.5 \\
107.1-110.7\end{array}$ & $115.16 \pm 1.08$ & $3.25 \pm .77$ & $2.82 \pm .66$ \\
\hline Radius & 8 & 9 & $\begin{array}{l}103.2-2128.0 \\
102.8-213.2\end{array}$ & $\begin{array}{l}271.36 \pm 1.40 \\
108.20 \pm 2.12\end{array}$ & & \\
\hline $\begin{array}{l}\text { Carpometa- } \\
\text { carpus }\end{array}$ & 8 & $\begin{array}{l}9 \\
3\end{array}$ & $\begin{array}{l}51.4-58.6 \\
50.4-51.9\end{array}$ & $54.42 \pm .78$ & $2.34 \pm .55$ & $4.30 \pm 1.01$ \\
\hline Phalanx 1 & 8 & 9 & $\begin{array}{l}17.3-20.1 \\
18.0-18.1\end{array}$ & $\frac{18.77}{18.03} \pm .27$ & $0.81 \pm .19$ & $4.31 \pm 1.02$ \\
\hline Phalanx 2 & 8 & $\begin{array}{l}9 \\
3\end{array}$ & $\begin{array}{l}16.7-18.0 \\
16.1-26.5\end{array}$ & $\frac{17.32}{16.33} \pm .114$ & $0.43 \pm .10$ & $2.48 \pm .58$ \\
\hline Fenur & \& & $\begin{array}{l}9 \\
5\end{array}$ & $\begin{array}{l}51.2-58.4 \\
52.8=55.1\end{array}$ & $\begin{array}{l}55.42 \pm .66 \\
53.84 \pm .50\end{array}$ & & \pm .84 \\
\hline Tibia & 8 & 9 & $\frac{126.0-11.12 .5}{123.5-126.5}$ & $\begin{array}{l}236.50 \pm 1.70 \\
125.50\end{array}$ & & $3.74 \pm .88$ \\
\hline Tarsus & 8 & $\begin{array}{l}8 \\
3\end{array}$ & $\begin{array}{l}95.7-107.9 \\
91.0-93.5\end{array}$ & $\begin{array}{c}101.50 \\
92.63\end{array} \pm 1.23$ & $3.67 \pm .87$ & $3.62 \pm .85$ \\
\hline Haglux & 8 & 9 & $\begin{array}{l}24.5-26.9 \\
24.3-24.5\end{array}$ & $25.88 \pm .26$ & $0.78 \pm .28$ & $3.02 \pm .71$ \\
\hline
\end{tabular}


Table 1 (cont.)

Skeletal neasurements (mis.)

Hydranassa tricolor ruflcol1s

Measurement Sex IN H

SD V

Sku27.

d $9225.6-144.5$

$135.50+1.92$

$5.77+1.36$

$4.26+1.00$

Besar slarl

$126.8-134.0$

$130.96+1.24$

$124.2-141.9$

$133.50+1.92$

126. $3-131.5$

$129.42+1.16$

Crentum

$42.8-46.0$

$44.20 \div .41$

$42.1-43.6$

$42.94 \div .29$

29.4-22.6

$21.39 \div .28$

20.9-22.2

$21.38 \div .25$

11. 3-12.7

$12.03 \div .12$

$10.6-11.8$

$11.44 \pm .23$

8.4 .9 .4

$8.86 \div .08$

$8.1-8.4$

$8.24 \pm .05$

11. $4-12.3$

$11.68 \div .09$

10.9-12.7

$11.14 \div .16$

10.1-11.4

$9.5-20.4$

$10.85 \div .09$

$10.16 \div .17$

Humerus

$92.5-100.6$

$96.48 \div .74$

$88.7-91.7$

$90.13 \div .60$

Una

$108.2-119.5$

11. $.50 \pm 1.04$

105.1-109. 2

$107.30 \div .89$

Radius

104.0-115.0

$109.50 \div 1.04$

$100.5-103.7 \quad 102.13 \pm .72$

Carpomete- o 11

$52.4-60.2$

$56.14 \pm .17$

carpus

$51.7-53.0$

$52.34 \pm .26$

18.9-22.0

$20.21 \div .20$

$27.7-19.6$

$18.78 \div .66$

$13.9-16.1$

$15.28 \div .24$

$13.7-16.6$

$14.50 \div .54$

$55.2-60.0$

$56.72 \pm .44$

$51.1-54.5$

$52.90 \div .43$

Mibla

$126.8-112.7$

$135.10 \div 1.74$

120.8-125.6

$120.06+2.51$

Tarsus

$89.2-108.4$

$101.90 \div 1.85$

$83.7-94.4$

$89.43 \pm 2.24$

Hallux

26. $2-29.3$

$27.41 \pm .214$

$25.0-26.9$

$25.80 \pm .38$

$2.78 \div .88$

$5.77 \pm 1.36$

$2.59 \pm .82$

$1.28 \div .29$

$0.65 \pm .21$

$0.92 \pm .20$

$0.55 \div .17$

$0.41 \div .09$

$0.52 \div .16$

$0.25 \div .06$

$0.11 \div .03$

$0.30 \div .06$

$0.36 \div .11$

$0.31 \div .07$

$0.39 \div .12$

$2.46 \div .53$

$1.53 \div .44$

$3.29 \pm .74$

$2.00 \div .63$

$3.29 \pm .74$

$1.81 \div .52$

$0.56 \div .13$

$0.58 \div .18$

$0.66 \div .15$

$1.48 \pm .47$

$0.78 \div .17$

$1.21 \div .38$

$1.47 \mp .31$

$1.10 \pm .32$

$5.50+1.23$

$5.63+1.78$

$5.83+1.30$

$5.02+1.59$

$0.78 \div .27$

$0.84 \pm .27$
$2.12 \div .67$

$4.32+1.02$

$2.00 \div .63$

$2.90 \pm .65$

$1.51 \div .48$

$4.28 \div .91$

$2.57 \div .81$

$3.37 \div .72$

$4.55+1.44$

$2.81 \pm .66$

$1.33 \div .42$

$2.56 \div .55$

$3.23 \pm 1.02$

$2.88 \div .61$

$3.84 \pm 1.22$

$2.55 \div .54$

$1.70 \pm .49$

$2.87 \div .64$

$1.86 \div .59$

$3.00 \div .67$

$1.77 \div .51$

$0.99 \mp .22$

$1.11 \mp .35$

$3.27 \div .73$

$7.88+2.49$

$5.13+2.15$

$8.34+2.64$

$2.59 \div .55$

$2.08 \div .60$

$4.07 \div .91$

$4.69+1.48$

$5.72+1.28$

$5.61+1.78$

$2.86 \div .61$

$3.26 \pm 1.03$ 
Table 1 (cont.)

Slceletel measurements (min.)

Syripma sibilatrix

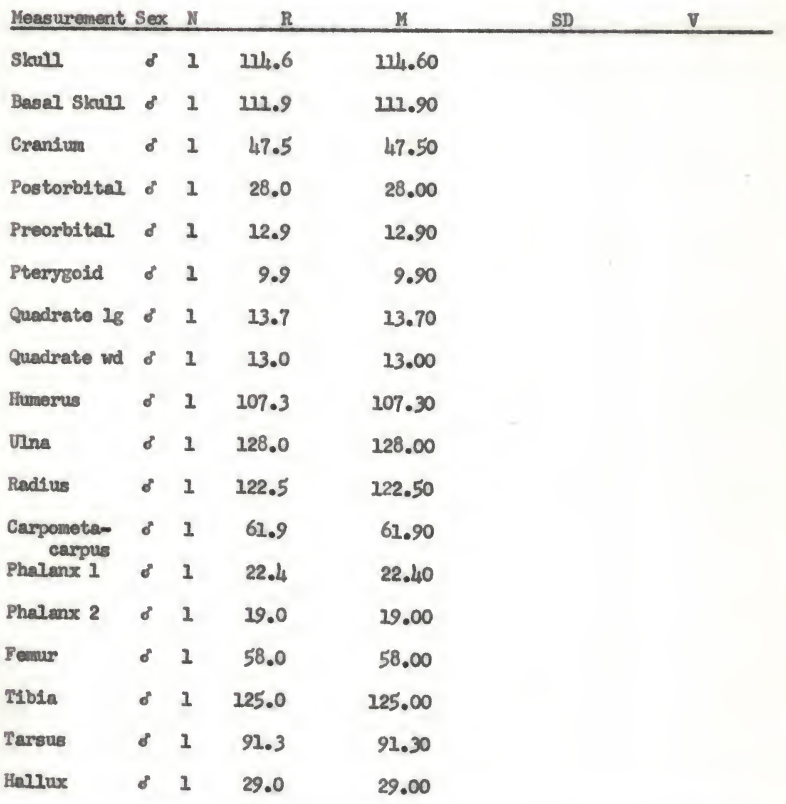


Table 1 (cont.)

Skeletal measurements (nm.)

Dycticorax nycticorex nycticorax

Messurement Sex N R M SD v Slower \& 4 $119.0-126.0 \quad 124.00 \pm 1.69$ $3.37 \pm 1.19$ $2.72 \pm .96$ Besal Skull of 4 $118.2-123.5 \quad 121.80 \pm 1.22$ $2.44 \pm .86$ $2.00 \pm .71$ Craniun of 4 $50.7-52.9 \quad 51.85 \pm .57 \quad 1.23 \pm .40 \quad 2.18 \pm .77$ Postorbital of 5 28.7-35.3 $33.10 \pm 1.16$ $2.60 \pm .827 .85 \pm 2.48$ Preorbital \& 5 $15.2-16.4$ $15.82 \pm .22$ $0.50 \pm .16 \quad 3.16 \pm 1.00$ Pterygoid \& Quadrate is \& 5 11.9-13.1 $12.42 \pm .23$ $0.45 \pm .14 \quad 3.62 \pm 1.15$ Quadrate wd \& 5 Humerus \& 4 $19.2-20.4$ $19.86 \pm .23$ $0.45 \pm .14 \quad 2.27 \pm .72$ Una 64 $25.5-16.3$ $16.02 \pm .15$ $0.33 \pm .20$ $2.06 \pm .65$ Radius × 4 $100.5-109.5$ $106.28 \pm 2.02$ $4.04 \pm 1.43$ $3.80 \pm 1.34$ $213.0-124.0 \quad 219.63 \pm 2.41 \quad 4.81 \pm 1.79 \quad 4.02 \pm 1.42$ Carponote- \& 4 $107.6-119.0 \quad 114.40 \pm 2.56$ $5.12 \pm 1.81 \quad 4.48 \pm 1.58$ earpus $55.9-60.8$ $57.60 \pm 1.11$ $2.22 \pm .78$ $3.85 \pm 1.37$ Phalanx 1 \& 4 $16.0-20.5 \quad 18.63 \pm .96$

Phalanx 2 \& 4 $17.0-19.8 \quad 18.48 \pm .57$ $1.92 \pm .68 \quad 10.31 \pm 3.64$ Fenar - 4 67.0-70.7 $68.88 \pm .94 \quad 1.88 \pm .66$ $6.11 \pm 2.16$ Tibia \& 4 $110.0-122.5 \quad 116.73 \pm 2.55$ $5.10 \pm 1.80 \quad 4.37 \pm 1.54$ Tarsus - 4 $73.2-76.8 \quad 74.88 \pm .67$ $1.33 \pm .47 \quad 1.78 \pm .63$ HeIlux \& 4 $25.2-27.2 \quad 26.23 \pm .36$ $0.72 \pm .25 \quad 2.74 \pm .97$ 
Table 1 (cont.)

Skeletal moasurements (m.)

Nyct icorax nyeticorax hoactis

Keasurenent Sex A

Sku17

917

Basal Skull : $\frac{24}{16}$

Crentivm of 24

Postorbital if 23

Preorbital of 24

Pterygoid \& 23

\& 16

Quadrate 28 of 24

Quadrate wd \& 24

Humervs

UIne

Radius

Carponeta- \& 16 carpus \& 15

Fhalanx 1

Phalanx 2

Ferour

Tibla

Tarsus

Hallux
816

\& 23

\& 15

- 22

815

\& 25

\& 22

\& 16

\& 22

\& 15

\& 20

\& 15

818

\& $\mathrm{U}_{4}$

8. 24

\& 15

\& 23

\& 16
R

$128,0-143.5136 .42+.70$

$122.3-139.0 \quad 130.53 \div .35$

$126.5-143.0135 .42 \div .78$

$121.3-134.8$

$54.9-59.5$

$53.3-57.8$

$34,6-40,0$

$35.3-37.8$

$16,4-18.7$

$16.1-19.0$

$12.9-15.2$

$12.9-14.3$

20.6-23.2

$19.6-22.0$

$16.6-19.1$

$16.4-18.2$

$224.3-128.8$

$106.0-116.2$

$221.3-137.5$

$124.4-130.8$

$127.4-131.6$

$109.5-124.6$

61.6-70.1

$59.2-65.3$

$21.1-24.8$

$21.0-23.5$

19.1-21. 5

18.6-21.1

$73.6-30.4$

71. 2-78.0

$219.6-136.4$

115. $8-133.0$

$77.0-89.7$

77.6086 .2

$26.8-31.8$

$26.88-32.6$
$128.88 \pm .35$

$57.42 \div .29$

$55.88 \div .35$

$37.74 \mp .22$

$36.43 \div .19$

$17.83 \mp .13$

$17.89 \div .17$

$14.42 \mp .11$

$13.65 \div .09$

$22.32 \div .13$

$21.16 \mp .214$

$28.03 \div .11$

$17.25 \mp .16$

$129.67 \div .68$

$112.60 \mp 1.02$

$230.50 \div .72$

$124.90+1.20$

$121.98 \mp .69$

$119.01+1.21$

$65.36 \mp .45$

$62.85 \div .28$

$23.08 \div .22$

$22.53 \div .18$

$20.32 \div .15$

$19.65 \div .19$

$77.17 \div .48$

$73.85 \div .47$

$128.50 \div .95$

$124.70+1.16$

$83.75 \div .70$

$81.07 \div .68$

$29.60 \div .28$

$28.90 \pm .31$
$3.44 \div .50$

$4.60 \div .25$

$3.80 \div .55$

$4.47 \mp .25$

$1.44 \div .21$

$1.41 \div .25$

$1.07 \div .16$

$0.70 \div .13$

$0.64 \div .09$

$0.68 \div .12$

$0.54 \div .08$

$0.37 \div .06$

$0.64 \div .09$

$0.57 \div .10$

$0.53 \div .08$

$0.64 \mp .11$

$3.28 \div .48$

$3.95 \div .72$

$3.38 \mp .51$

$4.63 \div .85$

$3.47 \div .49$

$4.83 \div .85$

$2.17 \div .32$

$2.22 \div .47$

$1.03 \div .15$

$0.73 \div .13$

$0.71 \div .11$

$0.75 \div .74$

$2.23 \div .34$

$1.84 \mp .34$

$4.03 \div .67$

$4.36 \mp .82$

$3.46 \div .50$

$2.62 \div .48$

$1.32 \div .20$

$1.23 \mp .22$ $\nabla$

$2.52 \pm .31$

$3.53 \div .61$

$2.80 \div .47$

$3.47 \div .61$

$2.51 \div .36$

$2.52 \div .45$

$2.84 \div .42$

$1.93 \div .36$

$3.59 \div .52$

$3.73 \div .66$

$3.74 \div .55$

$2.69 \div .48$

$2.87 \mp .41$

$2.70 \div .46$

$2.94 \div .42$

$3.69 \mp .69$

$2.74 \div .40$

$3.50 \div .64$

$2.59 \div .39$

$3.71 \div .68$

$2.78 \div .39$

$4.04 \div .72$

$3.32 \div .49$

$3.53 \div .65$

$4.45 \div .67$

$3.23 \div .57$

$3.50 \div .53$

$3.81 \div .70$

$2.75 \div .44$

$2.49 \div .46$

$3.24 \div .52$

$3.49 \div .66$

$4.23 \div .60$

$3.23 \mp .59$

$4.46 \div .66$

$4.27 \pm .75$ 


\section{8}

Table 1 (cont.)

Skeletel measurements (ma.)

Nreticorax celedonicus

\begin{tabular}{|c|c|c|c|c|c|c|}
\hline Yeasurement. & Sex & $\mathrm{N}$ & $\mathbf{R}$ & $M$ & SD & $v$ \\
\hline Skull & $?$ & 1 & 127.5 & 127.50 & & . \\
\hline Besal Skurl & $?$ & 1 & 126.5 & 126.50 & & \\
\hline Craniun & $?$ & 1 & 54.2 & 54.20 & & \\
\hline Postorbital & $?$ & 1 & 35.7 & 35.70 & & \\
\hline Preorbital & $?$ & 1 & 16.0 & 26.00 & & \\
\hline Pterygoid & $?$ & 1 & 12.5 & 12.50 & & \\
\hline Quadrate IB & $?$ & 1 & 19.3 & 19.30 & & \\
\hline Quadrate wd & $?$ & 2 & 25.3 & 25.30 & & \\
\hline Humerus & $?$ & 2 & 208.3 & 108.30 & & \\
\hline UIna & $?$ & 1 & 119.5 & 119.50 & & \\
\hline Radsius & $?$ & 1 & 214.1 & $2 u_{4} 10$ & & \\
\hline $\begin{array}{l}\text { Carponeta- } \\
\text { carpus }\end{array}$ & $?$ & 1 & 59.6 & 59.60 & & \\
\hline Phalanx I & $?$ & 1 & 20.9 & 20.90 & & \\
\hline Phalanx 2 & $?$ & 1 & 18.2 & 18.20 & & \\
\hline Fenur & $?$ & 1 & 71.0 & 71.00 & & \\
\hline THbia & $?$ & 1 & 123.0 & 123.00 & & \\
\hline Tarsus & $?$ & 1 & 81.0 & 81.00 & & \\
\hline Hallux & $?$ & 1 & 27.7 & 27.70 & & \\
\hline
\end{tabular}


Table 1 (cont.)

Skeletel measurements (m.)

Nyctanassa violacea violacea

Measurement Sex II

Skwar

Basal Skull

Cranium

Postorbital of $\frac{11}{8}$

Preorbital \& $\frac{11}{8}$

\& 11

Pterygoid \& 8

811

Quadrate 28 \& 7

Quadrate wd \& $\frac{17}{8}$

Humerus

UIna

Radius

Carpometecarpus

Phalanx 2

\& 11

Phalanx 2 of 8

Permar

Tibia

Tarsus

HaIIux

R

$\begin{array}{ll}118.5-121.5 & 122.25 \pm .71 \\ 111.4-122.5 & 118.32 \pm .98 \\ 116.0-123.0 & 120.50 \pm .82 \\ 110.0-121.8 & 116.95 \pm .97\end{array}$

$52.1-54.9$

$49.9-53.7$

$33.4-35.9$

$32.4-35.2$

$16.2-23.3$

$14.7-16.0$

$11.5-12.3$

20.6-12.3

18. $4-20.1$

17.9-20.1

$15.0-26.8$

$14.8-26.6$

$106.0-114.7$

103.5-2121.0

$125.6-230.4$

120.0-129.8

$119.5-123.5$

$111_{1} .5-124.3$

$59.0-63.5$

57.2-62.9

20.3-22.6

$20.3-23.7$

16. $4-20.4$

17.2-19.3

$63.3-69.8$

$62.3-68.3$

$133.6-248.0$

126.8-1143.5

95.8-107. 4

92.9-104.3

22.9-29.0

$22.1-25.2$
$53.25 \div .34$

$52.09 \div .35$

$34.50 \div .35$

$33.84 \div .29$

$20.50 \div .64$

$15.24 \div .14$

$11.88 \div .08$

$11.73 \div .15$

$19.30 \div .20$

$18.64 \div .17$

$15.68 \div .18$

$15.84 \div .16$

$110.00 \div 1.08$

$107.18 \div .75$

$227.61 \div .51$

$124.10 \div 2.13$

$121.63 \mp .51$

$118.68 \div 2.03$

$61.82 \pm .50$

$59.77 \div .53$

$21.50 \div .28$

$21.48 \div .89$

$18.40 \div .43$

$18.31 \mp .26$

$66.00 \div .59$

$64.70 \div .66$

$140.23 \$ 1.64$

$234.27+2.34$

$103.25+1.27$

$98.77 \mp 1.12$

$24.60 \div .47$

$23.99 \pm .31$
SD

v

$2.11 \pm .53 \quad 1.72 \pm .43$

$3.24 \pm .692 .74 \div .58$

$2.60 \mp .652 .16 \pm .54$

$3.20 \div .68 \quad 2.74 \div .58$

$0.97 \pm .24 \quad 1.82 \mp .46$

$1.16 \div .252 .23 \div .48$

$2.00 \div .252 .90 \div .72$

$0.95 \div .20 \quad 2.80 \mp .60$

$3.80 \div .45 \quad 8.80 \mp 2.20$

$0.48 \mp .10 \quad 3.13 \mp .67$

$0.23 \div .06 \quad 1.96 \div .49$

$0.51 \div .11 \quad 4.37 \div .93$

$0.52 \pm .14 \quad 2.71 \mp .72$

$0.57 \div .12 \quad 3.05 \div .65$

$0.52 \pm .13 \quad 3.31 \mp .83$

$0.51 \mp .11 \quad 3.25 \div .69$

$3.06 \mp .77 \quad 2.78 \mp .70$

$2.48 \div .53 \quad 2.31 \mp .49$

$1.36 \div .36 \quad 1.06 \mp .28$

$3.56 \mp .80 \quad 2.87 \mp .64$

$1.45 \div .36 \quad 1.19 \mp .29$

$3.41 \div .732 .87 \div .61$

$2.32 \div .352 .14 \div .57$

$1.76 \div .382 .95 \div .63$

$0.79 \div .20 \quad 3.69 \div .92$

$0.91 \mp .194 .24 \div .90$

$1.23 \div .316 .66 \div 1.66$

$0.85 \div .18 \quad 4.66 \div .99$

$2.68 \div .42 \quad 2.54 \div .64$

$2.19 \div .47 \quad 3.39 \div .72$

$4.64 \mp 2.16 \quad 3.31 \pm .83$

$4.45 \div .95 \quad 3.32 \div .72$

$3.60 \div .90 \quad 3.48 \div .87$

$3.72 \mp .79 \quad 3.77 \div .80$

$1.32 \div .335 .37 \div 2.34$

$2.04 \pm .22 \quad 4.33 \pm .92$ 
Table 1 (cont.)

Skeletal measurements ( $\left.\mathrm{mm}_{0}\right)$

Mretanassa violacea bancrofti

Measurement Sex IN R n

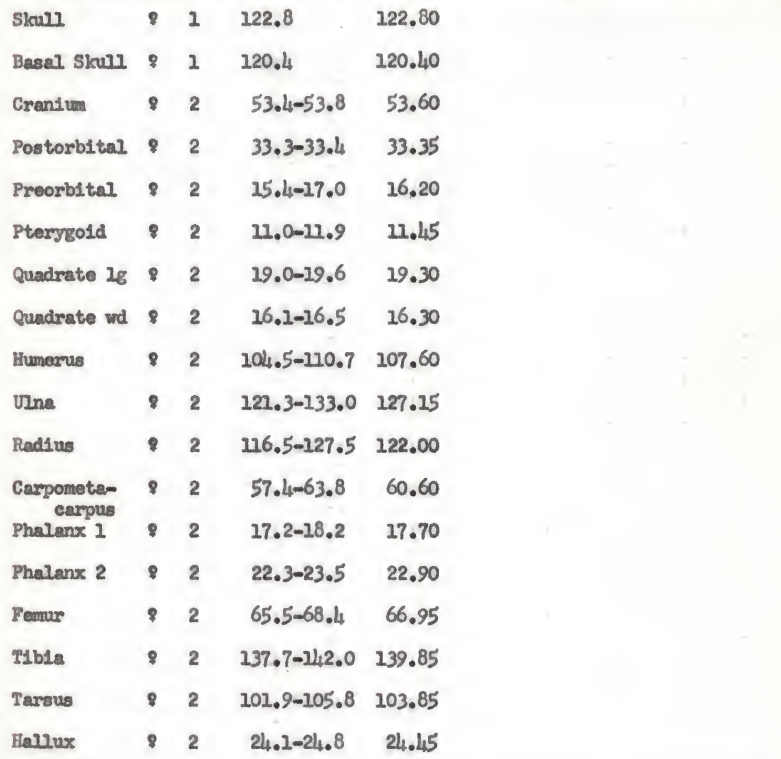


Table 1 (cont.)

Skeletal messurenents (min.)

Gorsachíus melanolophus

\begin{tabular}{|c|c|c|c|c|c|c|}
\hline Measurement & Sex & N & $\mathrm{R}$ & $M$ & $S D$ & $\nabla$ \\
\hline Skull & $?$ & 1 & 96.9 & 96.90 & & \\
\hline Basel Slcull & $?$ & 1 & 94.6 & 94.60 & & \\
\hline Cranium & $?$ & 1 & 47.6 & 47.60 & & \\
\hline Postorbital & $?$ & 1 & 29.9 & 29.90 & & \\
\hline Preorbital & $?$ & 1 & 12.9 & 12.90 & & \\
\hline Pterygoid & $?$ & 1 & 11.0 & 11.00 & & \\
\hline Qundrate $1 \mathrm{~g}$ & $?$ & 2 & 25.7 & 25.70 & & \\
\hline Quadrate wd & $?$ & 1 & 24.5 & 34.50 & & \\
\hline Humerus & $?$ & 1 & 97.5 & 97.50 & & \\
\hline Uns & $?$ & 1 & 113.7 & 213.70 & & \\
\hline Rad1us & $?$ & 1 & 109.4 & 109.40 & & \\
\hline $\begin{array}{l}\text { Carpometa- } \\
\text { carpus }\end{array}$ & $?$ & 1 & 54.3 & 54.30 & & \\
\hline Phalanx 1 & $?$ & 1 & 18.9 & 18.90 & & \\
\hline Phalanx 2 & $?$ & 1 & 25.1 & 15.20 & & \\
\hline Tenur & $?$ & 2 & 59.3 & 59.30 & & \\
\hline Tibla & $?$ & 1 & 204.7 & 104.70 & & \\
\hline Tarsus & $?$ & 1 & 70.0 & 70.00 & & \\
\hline Hallux & $?$ & 1 & 21.9 & 21.90 & & \\
\hline
\end{tabular}


Table 1 (cont.)

Skeletal messurements ( $\mathrm{mm}_{\mathrm{O}}$ )

Tigriornis leveolopha

Measurement Sex N

\begin{tabular}{|c|c|c|c|c|}
\hline Skwll & 8 & 2 & $114.5-147,0$ & $11,5.75$ \\
\hline Basal Skull & 8 & 2 & $\nu_{4} 3.0-\nu_{15} .0$ & 144.00 \\
\hline Cranium & 8 & 2 & $52.8-55.6$ & 54.20 \\
\hline Postorbital & $d$ & 2 & $27.6-28.8$ & 28.20 \\
\hline Preorbital & $d$ & 2 & $15.1-15.6$ & 15.35 \\
\hline Pterygoid & $\delta$ & 2 & $11.6-12.3$ & 11.95 \\
\hline Quadrate Ig & 8 & 2 & $15.2-15.2$ & 15.20 \\
\hline Quadrate wd & 8 & 2 & $12.4-12.8$ & 12.60 \\
\hline Humerus & $d$ & 2 & $91.9-92.6$ & 92.25 \\
\hline UIna & 8 & 2 & $104.6-109.1$ & 106.85 \\
\hline Radius & 6 & 2 & $99.0-102.6$ & 100.80 \\
\hline $\begin{array}{l}\text { Carpometa- } \\
\text { carpus }\end{array}$ & 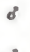 & 2 & $46.5-47.2$ & 46.85 \\
\hline Phalanx 1 & $d$ & 2 & $16.7-17.0$ & 26.25 \\
\hline Phalanx 2 & $\sigma^{\prime}$ & 2 & $22.3-12.6$ & 12.45 \\
\hline Fermur & 6 & 2 & $74.3-75.3$ & 74.80 \\
\hline Tibia & 8 & 2 & $115.1-120.0$ & 127.55 \\
\hline Tarsus & 6 & 2 & $77.2-78.1$ & 77.65 \\
\hline Hallux & 6 & 2 & $26.8-27.2$ & $27: 00$ \\
\hline
\end{tabular}


Table I (cont.)

Skeletal measurements (mo.)

Tigrisong 2ineatum

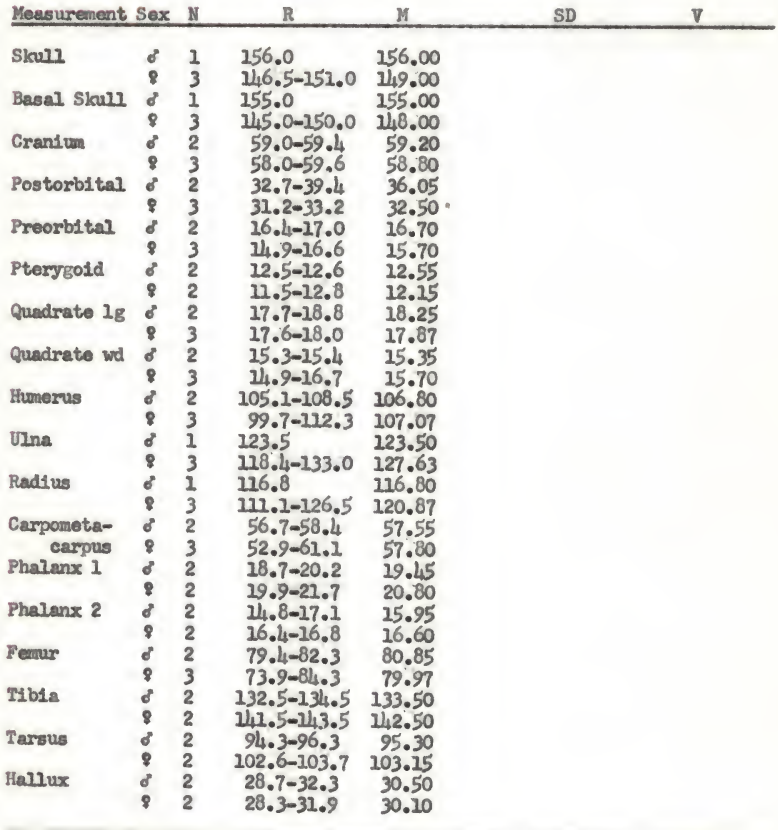


Table I (cont.)

Skeletal measurements (nm.)

Tierisoma mexicana

Measurement Sex N

Skatl

Basal Skcull

Crentum

Postorbital

? 2

Preorbital o 4

Pterygoid \&

quadrate is

Quadrate wd

Humerrus

UIna

Radius

Cerponetacarpus

Phalenx 1

Phalanx 2

Femur

Tibia

Tarvus

Hallux

\section{- 4}

82

\& 4

$\div 2$

84

82

\& 4

2

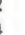

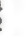

4

82

\& 4

? 2

( 4

\& 2

- 4

? 3

\& 4

\& 2

(5) 4

83

\& 4

84

o 4

84

\& 4

? 2

83

83

\& 3

82

\& 2

84 n

171.5-185.5

$161.0-184.5$

170.5-183.5

$160.0-183.5$

$63.0-68.0$

$63.5-65.3$

$33.5-35.9$

33.2-34.1

$14.9-17.1$

$16.0-16.5$

13.2-14.3

12.9-13.7

$16.6-19.9$

$17.7-18.5$

$16.0-16.8$

$15.6=17.4$

$126.0-1147.0$

120.0-133.5

$147.0-162.0$

$146.5-160.0$

$139.5-154.0$

$132.5-153.5$

$67.6-74.6$

65.7-71.0

$21.6-25.3$

23. $8-26.2$

$19.0-22.0$

20.6-22. 4

$90.4-97.7$

$85.1-93.2$

159.0-171.0

150.5-169.0

108.1-121. 5

108.3-117.9

$34.4-39.5$

$36.0-36.9$
M

$179.63 \pm 3.02$

172.95

$178.38 \pm 2.87 \quad 5.37 \pm 2.02 \quad 3.21 \pm 1.13$

171.75

$65.50+1.26$

64.40

$34.65 \pm .50$

33.65

$16.45 \pm .52$

16.25

$13.83 \pm .21$

13.30

$19.08 \pm .24$

18.10

$16.48 \pm .07$

16.50

$133.00 \pm 4.81$

125.83

$155.00+3.18$

253.25

$147.63 \pm 3.13$

141.33

$70.50 \pm 1.66$

68.35 $23.95 \pm .87 \quad 1.73 \pm .61 \quad 7.22 \pm 2.55$

25.00

$20.83 \pm .64 \quad 1.28 \pm .45 \quad 6.14 \pm 2.17$

93.13

88.07

163.17

159.75

$121.45 \pm 3.04 \quad 6.08 \pm 2.15 \quad 5.31 \pm 1.88$

213.10

$36.88 \pm 1.22 \quad 2.45 \pm .87 \quad 6.64 \pm 2.35$

$2.52 \pm .893 .85 \pm 1.36$

$0.99 \pm .35 \quad 2.86 \pm 1.01$

$1.04 \pm .37 \quad 6.32 \pm 2.23$

$0.41 \pm .14 \quad 2.96 \pm 1.05$

$0.47 \pm .17 \quad 2.46 \pm .87$

$0.14 \pm .05 \quad 0.85 \pm .30$

$9.62 \pm 3.40 \quad 7.23 \pm 2.55$

$6.36 \pm 2.25 \quad 4.10 \pm 1.45$

$6.26 \pm 2.22 \quad 4.24 \pm 1.50$

$3.32 \pm 1.27 \quad 4.71 \pm 1.66$ 36.45 
Table 1 (cont.)

Skelotal measurements (ma.)

Jrobrychus sinensis

Measurement Sex N

Skull

Basal Skull

Cranium

? 130.8

30.80

Postorbital ? $1 \quad 14.4$

Preorbital ? 1

8.3

14.40

Pterygoid ? 1

6.2

6.20

Quadrate is ? 1

9.1

9.10

Quadrate wd? 1

7.4

7.40

Hunerus

21

50.4

50.40

Una

$\begin{array}{lcccc}\text { Radius } & ? & 1 & 51.3 & 51.30 \\ \begin{array}{l}\text { Carpometa- } \\ \text { carpus }\end{array} & ? & 1 & 26.3 & 26.30 \\ \text { Phalanx 1 } & ? & 1 & 9.2 & 9.20 \\ \text { Phalanx 2 } & ? & 1 & 8.4 & 8.40 \\ \text { Pemur } & ? & 1 & 43.0 & 43.00 \\ \text { Tibla } & ? & 1 & 66.1 & 66.10 \\ \text { Targus } & ? & 1 & 44.0 & 44.00 \\ \text { Hallux } & ? & 1 & 17.9 & 17.90\end{array}$

80.80

8.30

SD V

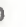


Table 1 (cont.)

Skeletal measurements (mm.)

Ixobrychus involucris

Messurement Sex II

R

V

Sku11

183.8

83.80

Basal Starl

\begin{tabular}{|c|c|c|c|c|}
\hline Crantum & $d$ & 1 & 31.8 & 31.80 \\
\hline Postorbital & $d$ & 1 & 15.8 & 15.80 \\
\hline Preorbital & $d$ & 1 & 8.4 & 8.40 \\
\hline Pterygold & 6 & 1 & 7.7 & 7.70 \\
\hline Quadrate 18 & $d$ & 1 & 9.1 & 9.10 \\
\hline Quadrate wd & $\delta$ & 1 & $7 \cdot 3$ & 7.30 \\
\hline Humerus & $d$ & 1 & 49.4 & 49.40 \\
\hline Una & $d$ & 1 & 51.6 & 51.60 \\
\hline Radius & $d$ & 1 & 49.5 & 49.50 \\
\hline $\begin{array}{r}\text { Carpometa- } \\
\text { carpus }\end{array}$ & 6 & 1 & 25.6 & 25.60 \\
\hline Phalanx 1 & $d$ & 1 & 9.3 & 9.30 \\
\hline Phalanx 2 & 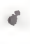 & 1 & 8.3 & 8.30 \\
\hline Ferwur & $d$ & 1 & 44.9 & 44.90 \\
\hline Tibla & 8 & 1 & 68.7 & 68.70 \\
\hline Tarsas & 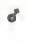 & 1 & 43.0 & 43.00 \\
\hline HaI1wx & 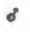 & 1 & 17.7 & 17.70 \\
\hline
\end{tabular}


Table 1 (cont.)

Skeletal measurements (ma)

Ixobrrychus exd14s

Measurement $\operatorname{Sex}$ N R x

SD $\nabla$

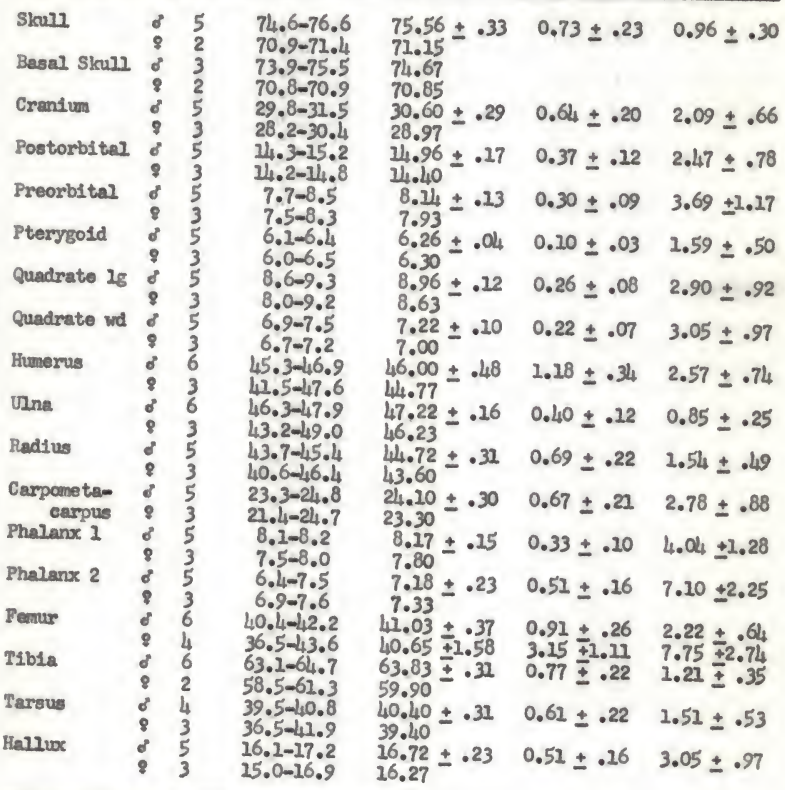


Table 1 (cont.)

Slceletal measurenents (m.)

Ixobrychus eimnanomeus

\begin{tabular}{|c|c|c|c|c|c|c|c|}
\hline Measurement & Sex & N & $R$ & $M$ & SD & $v$ & \\
\hline Skaul & 8 & 2 & 84.6 & 84.60 & & & \\
\hline Basal Skull & $\delta$ & 1 & 84.6 & 84.60 & & & \\
\hline Craniun & 8 & 1 & 35.3 & 35.30 & & & \\
\hline Postorbital & 8 & 1 & 18.9 & 18.90 & & & \\
\hline Preorbital & d & 1 & 11.4 & 11.40 & & & - \\
\hline Pterygoid & $\sigma$ & 1 & 7.3 & 7.30 & & & \\
\hline Quadrate If & 6 & 2 & 12.0 & $12 . \infty 0$ & & & \\
\hline Quadrate wd & $\delta$ & 1 & 9.1 & 9.10 & & & \\
\hline Humerus & $\sigma$ & 1 & 58.2 & 58.20 & & & \\
\hline Una & $\delta$ & 1 & 62.8 & 62.80 & & & \\
\hline Radius & 8 & 1 & 58.1 & 58.10 & & & \\
\hline $\begin{array}{l}\text { Carpomete- } \\
\text { cexpus }\end{array}$ & $\sigma$ & 1 & 33.4 & 33.40 & & & \\
\hline Phelanx 1 & o & 1 & 11.0 & 11.00 & & & \\
\hline Phelanx 2 & $\sigma$ & 1 & 9.8 & 9.80 & & & \\
\hline Fenmar & ' & 1 & 48.3 & 48.30 & & & \\
\hline Tibia & $\delta$ & 1 & 75.8 & 75.80 & & & \\
\hline Tarsus & $d$ & 1 & 47.9 & 47.90 & & & \\
\hline Hallux & 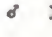 & 1 & 19.8 & 19.80 & & & \\
\hline
\end{tabular}


Table 1 (cont.)

Skeletal measurements (nus.)

Ixobrychus strumii

Measurement Sex IN

Skurl

Basal skulz \& 172.4

Cranium \& 135.0

Postorbital \& 129.3

Preorbital \& 19.6

Pterygold

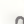

H

Ho

UIn

Re

ce

\section{$\mathrm{Ph}$}

Ph

se

Ty

$\mathrm{T}$

Ta

Hallux

R

u

74.90

72.40

35.00

19.30

9.60

9.90

9.00

62.70

67.70

64.40

35.30

12.10

11. 10

45.60

70.10

43.70

19.10 
Table 1 (cont.)

Skeletal messurenents (nm.)

Botaurus stellaris

Measurement Sex \& $M$

$S D$ $\nabla$

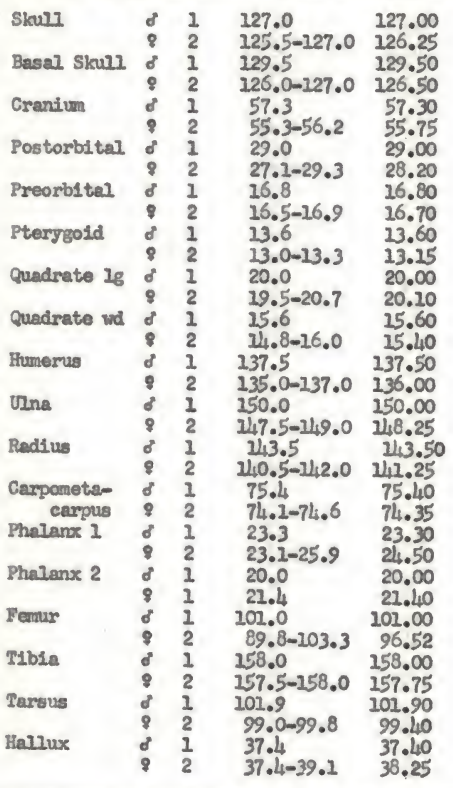


Table 1 (cont.)

Skeletal measurements (man)

Botaurus lent1ginosus

\begin{tabular}{|c|c|c|c|c|c|c|}
\hline Measurement & $e x$ & N & $\boldsymbol{R}$ & M & SD & V \\
\hline Skant & d & 9 & 119. & $127.50+1.16$ & $\begin{array}{l}3.46 \pm .82 \\
3.46 \div .82\end{array}$ & $\begin{array}{l}2.72 \pm \\
2.90 \div\end{array}$ \\
\hline Besal Skun & 8 & 8 & $0.0-134.0$ & $128.50 \pm 1.65$ & $.66 \geq 2.17$ & $3.63 \div .91$ \\
\hline Craniun & 8 & $\begin{array}{r}9 \\
10 \\
9\end{array}$ & $\begin{array}{l}114.0-125.5 \\
51.5-54.4 \\
46.9-53.2\end{array}$ & $\begin{array}{l}118.60 \pm 1.05 \\
53.08 \pm .33 \\
48.66 \div .77\end{array}$ & $\begin{array}{l}3.16 \pm .75 \\
1.04 \pm .23 \\
2.32 \pm .55\end{array}$ & $\begin{array}{l}2.67 \pm .39 \\
1.96 \pm .44 \\
4.77 \div 1.12\end{array}$ \\
\hline Postorbital & 8 & $\begin{array}{r}10 \\
8\end{array}$ & $\begin{array}{l}25.0- \\
24.4-\end{array}$ & $\begin{array}{l}26.24 \pm .16 \\
25.45 \pm .27\end{array}$ & $0.51 \pm .11$ & $\frac{1.95}{2.95 \pm .74}$ \\
\hline Preorbital & 8 & $\begin{array}{r}9 \\
8\end{array}$ & 14.0 & $15.35 \pm .29$ & $0.87 \pm .21$ & $\begin{array}{l}5.69 \pm 1.34 \\
3.06 \pm 1.25\end{array}$ \\
\hline Pterygoid & 8 & $\begin{array}{r}10 \\
9\end{array}$ & $\begin{array}{r}10.5-11.9 \\
9.4-11.6\end{array}$ & $\begin{array}{l}12.27 \pm .15 \\
10.16 \pm .27\end{array}$ & $\begin{array}{l}0.49 \pm .12 \\
0.82 \pm .19\end{array}$ & $32 \pm .97$ \\
\hline Quadrate If & 8 & $\begin{array}{r}10 \\
9\end{array}$ & & $\begin{array}{l}17.38 \pm .15 \\
16.26 \pm .23\end{array}$ & $\begin{array}{l}0.48 \pm .11 \\
0.70 \pm .17\end{array}$ & $\begin{array}{l}2.73 \pm .61 \\
4.31 \pm 1.02\end{array}$ \\
\hline Quadrate wd & 8 & $\begin{array}{r}10 \\
9\end{array}$ & $\begin{array}{l}23.0-14.5 \\
12.4-11.5\end{array}$ & $13.64 \div .14$ & $0.43 \pm .10$ & $\begin{array}{l}3.16 \pm .72 \\
4.37 \pm 1.03\end{array}$ \\
\hline Hunerus & 8 & $\begin{array}{r}10 \\
8\end{array}$ & $\begin{array}{r}107.5-118.0 \\
93.2-115.5\end{array}$ & $\frac{112.80 \pm .81}{104.50 \pm 1.03}$ & $\begin{array}{l}2.56 \pm .57 \\
2.92 \pm .73\end{array}$ & $\begin{array}{l}2.27 \pm .51 \\
2.78 \pm .70\end{array}$ \\
\hline Una & 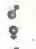 & $\begin{array}{l}9 \\
9\end{array}$ & $\begin{array}{l}115.5-129.5 \\
103.0-127.5\end{array}$ & $\begin{array}{l}123.49 \pm 2.10 \\
114.00 \pm 2.31\end{array}$ & $\begin{array}{l}3.30 \pm .78 \\
6.93 \pm 1.63\end{array}$ & $\begin{array}{l}2.67 \pm .63 \\
6.08 \pm 1.43\end{array}$ \\
\hline Radius & 8 & 9 & $\begin{array}{r}109.5-122.0 \\
97.5-122.5\end{array}$ & $\begin{array}{l}216.50 \pm 1.22 \\
107.68 \pm 2.28\end{array}$ & $\begin{array}{l}2.65 \pm .86 \\
6.83 \pm 1.61\end{array}$ & $\begin{array}{l}3.13 \pm .74 \\
6.34 \pm 1.49\end{array}$ \\
\hline $\begin{array}{l}\text { Carpometa- } \\
\text { carpus }\end{array}$ & 8 & $\begin{array}{r}10 \\
9\end{array}$ & & $\begin{array}{l}64.00 \pm .68 \\
60.17 \pm 1.10\end{array}$ & $\begin{array}{l}2.15 \pm .48 \\
3.30 \pm .79\end{array}$ & \\
\hline Phalanx 1 & 8 & $\begin{array}{r}10 \\
9\end{array}$ & -21.9 & $21.00 \pm .24$ & $\begin{array}{l}0.76 \pm .17 \\
1.40 \pm .33\end{array}$ & $7.09+1.6$ \\
\hline Phalanx 2 & 8 & $\begin{array}{l}8 \\
7\end{array}$ & $\begin{array}{l}16.0 \\
14.0\end{array}$ & $\begin{array}{l}17.45 \pm .29 \\
17.85 \pm .33\end{array}$ & $\begin{array}{l}0.81 \pm .20 \\
0.87 \pm .23\end{array}$ & $\begin{array}{l}4.63 \pm 1.16 \\
4.89 \pm 1.31\end{array}$ \\
\hline Fenur & 8 & $\begin{array}{l}9 \\
8\end{array}$ & $\begin{array}{l}78.5-85.0 \\
66.3-85.9\end{array}$ & $\begin{array}{l}82.57 \pm .83 \\
75.87 \pm 2.06\end{array}$ & $\begin{array}{l}2.50 \pm .69 \\
5.83 \pm 1.46\end{array}$ & $\begin{array}{l}3.02 \pm .72 \\
7.68 \pm 1.92\end{array}$ \\
\hline Tibla & 8 & $\begin{array}{l}9 \\
9\end{array}$ & $\begin{array}{l}127.5-139.0 \\
109.2-134.0\end{array}$ & $\begin{array}{l}134.17 \pm 1.10 \\
121.68 \pm 2.27\end{array}$ & $\begin{array}{l}3.30 \pm .78 \\
6.80 \pm 1.60\end{array}$ & $\begin{array}{l}2.46 \pm .58 \\
5.59 \pm 1.32\end{array}$ \\
\hline Tarsus & 8 & 9 & $\begin{array}{l}80.7-95.7 \\
75.1-91.8\end{array}$ & $\begin{array}{l}91.00 \pm 1.83 \\
83.32 \pm 1.73\end{array}$ & $\begin{array}{l}5.48 \pm 1.29 \\
5.18 \pm 1.22\end{array}$ & $\begin{array}{l}6.02 \pm 1.42 \\
6.22 \pm 1.47\end{array}$ \\
\hline Hallux & 8 & $\begin{array}{r}10 \\
9\end{array}$ & $\begin{array}{l}34.6-37.3 \\
30.9-37.0\end{array}$ & $\begin{array}{l}35.75 \pm .26 \\
33.69 \pm .58\end{array}$ & $\begin{array}{l}0.83 \pm .19 \\
1.75 \pm .41\end{array}$ & $\begin{array}{l}2.32 \pm .52 \\
5.19 \pm 1.22\end{array}$ \\
\hline
\end{tabular}


Table I (cont,)

Skeletel measuremente (mon)

Cochlearius cochlearius

Measurement Sex N

x

$S D$

v

Skant]

? $2 \quad 219.9-124.5 \quad 122.20$

Basal Skul1 ? 2 126.5-119.0 217.75

Cranium ? $2 \quad 53.6-54.0 \quad 53.80$

Postorbital ? $2 \quad 37.5-37.7 \quad 37.60$

Preorbital ? $2 \quad 19.0-22.0 \quad 20.50$

Pterygold ? $2 \quad$ 12.4-13.1 12.75

Quadrate Ig ? $2 \quad 19.0-19.4 \quad 19.20$

Quadrate wd ? $2 \quad 18.2-18.2 \quad 18.20$

$\begin{array}{lllll}\text { Humerus } & 2 & 92.9-95.0 & 93.95\end{array}$

Una ? $2 \quad 105.3-112.2 \quad 108.25$

Radius ? $2 \quad 99.9-104.9 \quad 102.40$

Carpomete- ? $2 \quad 48.0-49.0 \quad 48.50$

carpus

Phalanx 1 ? 2 18.4-19.0 18.70

Phalanx 2 ? $2 \quad 15.5-16.3 \quad 25.90$

Ferour ? $2 \quad 65.7-66.2 \quad 65.95$

Tibie ? 2 111.4-123.0 117.20

$\begin{array}{lllll}\text { Tarsus } & 2 & 2 & 72.5-82.6 & 77.55\end{array}$

Halluxe ? $\quad$ ? $\quad 25.6 \quad 25.60$ 
Table 2

Retios (per cent)

Ardes surnatrane

\begin{tabular}{|c|c|c|c|c|c|}
\hline Patio & $N$ & R & M & $S D$ & v \\
\hline Pre/sk & 1 & 9.2 & 9.20 & & \\
\hline Pre/Post & 1 & 57.4 & $57 \cdot 40$ & & \\
\hline Pre/Cr & 1 & 28.8 & 28.80 & & \\
\hline Post/Cr & 2 & 50.2 & 50.10 & & \\
\hline$P t / Q_{2}$ & 1 & 61.7 & 61.70 & & \\
\hline $0 w / 02$ & 2 & 81.3 & 82.30 & & \\
\hline $\mathrm{Pe} / \mathrm{hu}$ & $\bar{l}$ & 62.5 & 62.50 & & \\
\hline $\mathrm{Pe} / \mathrm{UI}$ & 2 & 50.2 & 50.20 & & \\
\hline $\mathrm{Fe} / \mathrm{Cme}$ & I & 124.9 & 124.90 & & \\
\hline $\mathrm{T1} / \mathrm{Hu}$ & 1 & 230.7 & 130.70 & & \\
\hline T2/U2 & 1 & 104.9 & 304.90 & & \\
\hline $\mathrm{TL} / \mathrm{Cme}$ & 2 & 261.2 & 261.20 & & \\
\hline $\mathrm{Ta} / \mathrm{Ha}$ & 2 & 91.1 & 91.10 & & \\
\hline $\mathrm{T} / \mathrm{JI}$ & $i$ & 73.1 & 73.10 & & \\
\hline $\mathrm{Ta} / \mathrm{Cano}$ & 2 & 181.9 & 181.90 & & \\
\hline Be/lla & 1 & 27.4 & 27.40 & & \\
\hline $\mathrm{He} / \mathrm{UI}$ & $i$ & 22.0 & 22.00 & & \\
\hline $\mathrm{Ha} / \mathrm{Cme}$ & $\overrightarrow{2}$ & 54.8 & 54.80 & & \\
\hline $\mathrm{Hu} / \mathrm{OI}$ & $i$ & 80.3 & 80.30 & & \\
\hline $\mathrm{Ra} / \mathrm{vI}$ & 2 & 91.7 & 91.70 & & \\
\hline Cme/OI & $\vec{i}$ & 40.2 & 40.20 & & \\
\hline$P-1 / 02$ & $\vec{i}$ & 14.6 & $u_{4.60}$ & & \\
\hline$P-2 / U 1$ & $\overline{1}$ & 12.1 & 12.20 & & \\
\hline $\mathrm{Fe} / \mathrm{TI}$ & 1 & 47.8 & 47.80 & & \\
\hline $\mathrm{Ta} / \mathrm{xI}$ & 2 & 69.7 & 69.70 & & \\
\hline $\mathrm{Ha} / \mathrm{h1}$ & 2 & 22.0 & 22.00 & & \\
\hline
\end{tabular}


Table 2 (cont.)

Ratios (pers cent)

Ardes goliath

\begin{tabular}{|c|c|c|c|c|c|}
\hline Rat10 & II & R & $M$ & $S D$ & v \\
\hline $\begin{array}{l}\text { Pre/Sk } \\
\text { Pre/Post }\end{array}$ & $\begin{array}{l}4 \\
2\end{array}$ & $\begin{array}{l}20.4-117.1 \\
54.6-57.0\end{array}$ & $\frac{10.65}{55.80} \pm .16$ & $0.32 \pm .21$ & $3.00 \pm 1.06$ \\
\hline $\mathrm{Pre} / \mathrm{Cs}$ & 4 & $29.3-31.7$ & $30.65 \pm .53$ & $1.05 \pm .37$ & $3.43 \pm 1.21$ \\
\hline Poot/Cr & 2 & $53.7-55.6$ & $54.65^{-}$ & & \\
\hline Pt/Q1 & 3 & $58.5-63.2$ & 60.23 & & \\
\hline $\mathrm{ar} / \mathrm{el}$ & 4 & $78.1-83.0$ & $80.25 \pm 1.12$ & $2.214 \pm .79$ & $2.79 \pm .99$ \\
\hline $\begin{array}{l}\mathrm{F} / \mathrm{Hu} \\
\mathrm{F} / \mathrm{vL}\end{array}$ & $\begin{array}{l}4 \\
2\end{array}$ & $\begin{array}{l}56.7-61.4 \\
51.5-54.3\end{array}$ & $\begin{array}{l}58.70 \pm .99 \\
52.90\end{array}$ & $1.97 \pm .70$ & $3.36 \pm 1.19$ \\
\hline Fo/canc & 3 & $2 v_{4} .8-120.7$ & 117.30 & & \\
\hline $\mathrm{T} 2 / \mathrm{Hu}$ & 3 & $121.2-127.6$ & 125.57 & & \\
\hline 21/v2 & 2 & $120.1-122.5$ & 110.80 & & \\
\hline 21/Came & 3 & $252.7-257.7$ & 254.66 & & \\
\hline Ta/Hu & 4 & $87.5-92.0$ & $88.83 \pm .99$ & $1.97 \pm .70$ & $2.22 \pm .78$ \\
\hline Ta/v & 2 & $77.4-77.9$ & $77.65-$ & & \\
\hline $\begin{array}{l}\text { Te/Canc } \\
\text { He/thu }\end{array}$ & $\begin{array}{l}3 \\
3\end{array}$ & $174.5-186.1$ & $\begin{array}{r}181.00 \\
27.63\end{array}$ & & \\
\hline Iapis & 2 & $21.2-25.1$ & $\begin{array}{l}27.03 \\
24.65\end{array}$ & & \\
\hline $\mathrm{Hi} / \mathrm{Canc}$ & 2 & $54.3-56.6$ & 55.45 & & \\
\hline Buy & 2 & $88.5-38.7$ & 88.60 & & \\
\hline $\mathrm{Re} / \mathrm{VI}$ & 2 & $95.0-96.2$ & 95.55 & & \\
\hline $\begin{array}{l}\mathrm{Cnc} / \mathrm{VI} \\
\mathrm{P}-\mathrm{L} / \mathrm{VI}\end{array}$ & $\begin{array}{l}2 \\
2\end{array}$ & $\begin{array}{l}42.7-4.4 \\
15.7-17.2\end{array}$ & $\begin{array}{l}43.35 \\
16.60\end{array}$ & & \\
\hline$P-2 / 01$ & $i$ & 23.1 & 23.10 & & \\
\hline $\mathrm{Fe} / \mathrm{M}$ & 3 & $45.5-46.8$ & 46.73 & & \\
\hline $\mathrm{T} / \mathrm{TI}$ & 3 & $68.8-73.7$ & 71.10 & & \\
\hline T2/ 11 & 2 & $21.4-21.9$ & 21.65 & & \\
\hline
\end{tabular}




\section{Table 2 (cont.) \\ Ratios (per cent) \\ Andea melanocenhola}

\begin{tabular}{|c|c|c|c|c|c|}
\hline Patto & N & $R$ & $x$ & SD & $\nabla$ \\
\hline Pre/Sk & 2 & $11.2-11.4$ & 11.30 & & \\
\hline Pre/Post & 2 & $50.7-51.3$ & 51.00 & & \\
\hline Pre/Cr & 2 & $29.2-30.3$ & 29.75 & & \\
\hline Post/Cr & 2 & $56.9-59.8$ & 58.35 & & \\
\hline Pt/O2 & 2 & $61.9-64.8$ & 63.35 & & \\
\hline $00 / 02$ & 2 & $79.7-79.8$ & 79.75 & & \\
\hline $\mathrm{Fe} / \mathrm{lhu}$ & 2 & $55.5-55.5$ & 55.50 & & \\
\hline $\mathrm{Fe} / \mathrm{Ur}$ & 2 & $47.2-47.6$ & 47.40 & & \\
\hline $\mathrm{Fe} / \mathrm{Cme}$ & 2 & $105.5-103.7$ & 107.10 & & \\
\hline TI/Ha & 2 & $125.1-127.2$ & 126.15 & & \\
\hline II/UI & 2 & $106.5-109.1$ & 107.80 & & \\
\hline $\mathrm{TI} / \mathrm{Gme}$ & 2 & $21.5 .3-21,9.1$ & 247.20 & & \\
\hline Ta/hu & 2 & $91.1-93.6$ & 92.35 & & \\
\hline $\mathrm{T} / \mathrm{WI}$ & 2 & $77.6-80.2$ & 78.90 & & \\
\hline $\mathrm{Ta} / \mathrm{Cnn}$ & 2 & $178.7-183.2$ & 180.95 & & \\
\hline $\mathrm{Ha} / \mathrm{Hu}$ & 2 & $21.7-23.1$ & 22.40 & & \\
\hline $\mathrm{Ba} / \mathrm{UI}$ & 2 & $18.6-19.6$ & 19.10 & & \\
\hline $\mathrm{Ha} / \mathrm{Gne}$ & 2 & $42.4-45.1$ & 43.75 & & \\
\hline $\mathrm{Ilu} / \mathrm{OI}$ & 2 & $85.2-85.7$ & 85.60 & & \\
\hline $\mathrm{Ra} / \mathrm{OI}$ & 2 & $96.2-96.5$ & 96.35 & & \\
\hline $\mathrm{Cme} / \mathrm{UI}$ & 2 & $43.4 \sim 43.8$ & 43.60 & & \\
\hline$P-1 /$ UI & 2 & $v_{1} \cdot 2-15.4$ & 14.80 & & \\
\hline $\mathrm{P}-2 / \mathrm{UL}$ & 2 & $13.5-13.7$ & 23.60 & & \\
\hline $\mathrm{Pe} / \mathrm{M}$ & 2 & $43.7-44.4$ & Wh. 05 & & \\
\hline $\mathrm{Ta} / \mathrm{TI}$ & 2 & $72.8-73.6$ & 73.20 & & \\
\hline $\mathrm{E} / \mathrm{TL}$ & 2 & $17.0-18.4$ & 17.70 & & \\
\hline
\end{tabular}




\author{
Table 2 (cont.) \\ Ratios (per cent) \\ Arden cineres
}

\begin{tabular}{|c|c|c|c|c|c|}
\hline Ratio & $\mathbb{N}$ & R & U & SD & $\nabla$ \\
\hline e/Sk & 9 & $10.1-17.9$ & $10.76+3.33$ & $0.40+.94$ & $3.72+.88$ \\
\hline Pre/Post & 9 & $53.6-60.8$ & $56.37 \mp .77$ & $2.31 \mp .54$ & $4.10 \mp .97$ \\
\hline $\mathrm{Pre} / \mathrm{Cr}$ & 9 & $27.7-32.6$ & $29.72 \mp$ & $3.89 \mp$ & $6.36+2.50$ \\
\hline Post/Cx & 9 & $50.0-55.9$ & $52.71 \mp$ & $1.70 \mp .40$ & $3.23 \mp .76$ \\
\hline $\mathrm{Pt} / \mathrm{O}$ & 9 & $58.5-66.7$ & $63.63 \div 1.02$ & $3.05 \div .72$ & $4.79 \mp 1.13$ \\
\hline $\mathrm{Qw} / \mathrm{OI}$ & 9 & $74.8=85.0$ & $78.64 \mp 1.07$ & $3.22 \mp$ & $4.09 \mp .96$ \\
\hline $\mathrm{Fe} / \mathrm{tha}$ & 12 & $49.8-53.5$ & $51.80 \mp .34$ & $1.14 \div$ & $2.20 \div$ \\
\hline $\mathrm{Fe} / \mathrm{UI}$ & 9 & $42.5-45.8$ & $44.20 \mp$ & $1.02 \div .24$ & $2.31 \mp .54$ \\
\hline Fe/ Cne & 10 & $94.7-100.0$ & $97.33 \div$ & $2.13 \div .48$ & $2.19 \div .49$ \\
\hline $\mathrm{TL} / \mathrm{Hu}$ & 9 & $220.7-125.1$ & $316.62 \div 1.51$ & $4.54+1.07$ & $3.89 \div$ \\
\hline $11 / v 1$ & 9 & $94.7-102.1$ & $99.02 \div .98$ & $2.94 \mp .69$ & $2.79 \div$ \\
\hline TI/Gme & 10 & $206.9-230.1$ & $229.63 \div 2.42$ & $7.64 \div 1.71$ & $3.48 \div$ \\
\hline $\mathrm{Te} / \mathrm{ha}$ & 9 & $80.4-92.4$ & $87.40 \mp 1.21$ & $3.63 \div .86$ & $4.15 \div .98$ \\
\hline Ta/us & 9 & $68.7-76.7$ & $74.29 \mp .81$ & $2.43 \div .57$ & $3.27 \pm .77$ \\
\hline Ta/Gune & 10 & $250.1-171.0$ & $164.51 \pm 2.03$ & $6.42 \mp 1.44$ & $3.90 \mp .87$ \\
\hline $\mathrm{Ha} / \mathrm{Hu}$ & 9 & $19.7-22.5$ & $20.44 \div \div .32$ & $0.95 \div .22$ & $4.65+1.10$ \\
\hline $\mathrm{HQ} / \mathrm{UL}$ & 9 & $16.8-18.2$ & $17.26 \mp$ & $0.36 \mp$ & $2.09 \div .49$ \\
\hline $\mathrm{Ha} /$ ance & 10 & $36.9-41.3$ & $38.39 \mp$ & $0.85 \mp$ & $2.27 \div .49$ \\
\hline ha/v1 & 8 & $83.8-86.8$ & $85.33 \div$ & $0.47 \div .12$ & $0.55 \div .14$ \\
\hline $\mathrm{R} / \mathrm{V}$ & 9 & $95.8-97.2$ & $96.36 \mp$ & $0.94 \div .22$ & $0.98 \mp .23$ \\
\hline $\mathrm{Cme} / \mathrm{UL}$ & 9 & $44.0-46.1$ & $45.34 \div$ & $0.87 \div .21$ & $1.92 \div .45$ \\
\hline$P-1 / U 1$ & 9 & $15.1-16.4$ & $15.86 \mp$ & $0.62 \mp .14$ & $3.85 \mp .91$ \\
\hline$P-2 / U 1$ & 9 & $23.1-14.2$ & $13.48 \mp$ & $0.88 \mp .21$ & $6.53-1.54$ \\
\hline $\mathrm{Te} / \mathrm{II}$ & 10 & $43.0-48.3$ & $44.36 \pm$ & $2.69 \div .38$ & $3.81 \mp .85$ \\
\hline $\mathrm{Ta} / \mathrm{MI}$ & 10 & $72.6=80.8$ & $74.93 \div$ & $2.52 \pm .56$ & $3.36 \pm .75$ \\
\hline $\mathrm{I} / \mathrm{a} / \mathrm{II}$ & 10 & $16.8-18.0$ & $17.47 \div$ & $0.37 \div .08$ & $2.12 \div .47$ \\
\hline
\end{tabular}


Table 2 (cont,)

Ratlos (per cont)

Ardea herodies trecanzal

\begin{tabular}{|c|c|c|c|c|c|}
\hline Ratio & N & R & $\mathrm{M}$ & SD & $\nabla$ \\
\hline Pre/Sk & 7 & $9.2-9.9$ & $9.61+.43$ & $1.14 \pm .30$ & $21.86 \pm 3.2$ \\
\hline Pre/Post & 8 & $53.1-57.8$ & $55.68 \pm 2.53$ & $7.15 \div 1.79$ & $12.84=3.2$ \\
\hline Pre/Cr & 7 & $27.0-29.0$ & $28.46 \mp .04$ & $0.37 \pm .10$ & 1.30 \\
\hline Post/Cr & 7 & $49,6-51.9$ & $50.77 \pm .36$ & $0.95 \mp .25$ & \\
\hline $\mathrm{Pt} / \mathrm{O} 1$ & 8 & $58.9 m 67.0$ & $62.66+1.13$ & $3.19 \pm .80$ & $5.09 \pm 1.2$ \\
\hline$m / \phi 1$ & 8 & $79.0-84.5$ & $81.96 \mp .71$ & $2.01 \mp .50$ & $2.45 \pm .6$ \\
\hline $\mathrm{Fe} / \mathrm{Hh}$ & 5 & $52,4-53.9$ & $53.52 \mp .28$ & $0.63 \div .20$ & $2.18 \div$ \\
\hline $\mathrm{Pe} / \mathrm{UI}$ & 7 & $43.9-40.5$ & $.5 .73 \mp .72$ & $1.90 \pm .51$ & $4.15 \pm 1.1$ \\
\hline o/One & $?$ & $98,8-103.7$ & $101.29 \mp .61$ & $1.62 \mp .43$ & $1.60 \pm$ \\
\hline 14/the & 5 & $121,0-132.9$ & $128.48+1.09$ & $4.23+1.34$ & $3.29 \mp$ \\
\hline Ti/v2 & 7 & $204.0-112.3$ & $109,00+1.09$ & $2.90 \div .78$ & $2.66 \pm$ \\
\hline II/Cne & $?$ & $229.7-24.9 .2$ & $212.31+2.75$ & $7.29 \mp 1.95$ & $3.02 \div$ \\
\hline $\mathrm{Ta} / \mathrm{llu}$ & 5 & $92.8-96.2$ & $95.014 \pm .67$ & $1.49 \mp .47$ & $1.57 \mp$ \\
\hline $\mathrm{Pa} / \mathrm{UI}$ & 7 & $79.7-81.9$ & $80.63 \mp .30$ & $0.80 \div .25$ & $0.99 \mp$ \\
\hline Palcine & 7 & $170.6-181.6$ & $178.29+1.36$ & $3.61+1.15$ & $2.02 \mp$ \\
\hline Ha/the & 5 & $21.8-21.0$ & $23.16 \mp .39$ & $0.88 \div .28$ & $3.80 \div$ \\
\hline $\mathrm{Ha} / \mathrm{u}$ & 8 & $19.2-21.3$ & $19.84 \mp .24$ & $0.67 \div .17$ & $3.38 \div$ \\
\hline $\mathrm{Pla} / \mathrm{Cme}$ & 8 & $42.7-15.2$ & $43.93 \mp .25$ & $0.70 \div .28$ & $1.59 \div$ \\
\hline $\mathrm{An} / \mathrm{UI}$ & 5 & $83.3-88.0$ & $85.03 \mp .67$ & $1.51 \div .48$ & $1.78 \div \ldots$ \\
\hline Re/us & 7 & $96.0-97.2$ & $96.31 \pm .57$ & $1.51 \pm .48$ & $1.57 \div$ \\
\hline $\operatorname{arc} / v_{1}$ & 8 & $44.4-47.2$ & $45.18 \mp .39$ & $1.07 \mp .27$ & $2.37 \div$ \\
\hline$-1 / 02$ & 7 & $16.1-18.4$ & $16.88 \div .23$ & $0.61 \div .19$ & $3.61 \div 1.1$ \\
\hline$-2 / 01$ & $?$ & $13.2-14.5$ & $23.79 \pm .17$ & $0.144 \pm .24$ & $3.29 \pm 1.0$ \\
\hline $\mathrm{e} / \mathrm{TI}$ & 7 & $40.5-43.8$ & $41.91 \div .38$ & $1.00 \mp .32$ & $2.38 \mp .76$ \\
\hline $12 / 11$ & 7 & $72.3-77.6$ & $74.01 \div .65$ & $1.72 \mp .55$ & $2.32 \mp$ \\
\hline $\mathrm{Aa} / \mathrm{T1}$ & 7 & $17.3-19.3$ & $28.23 \pm .34$ & $0.90 \mp .29$ & $4.94 \mp 2.57$ \\
\hline
\end{tabular}


Table 2 (cont.)

Ratioo (per cent)

Ardee herodias herodias

\begin{tabular}{|c|c|c|c|c|c|}
\hline Ratio & N & B & M & $S D$ & v \\
\hline Pre/sis & 37 & $8.8-10.2$ & $9.64 \pm$ & $0.35 \pm .04$ & $3.63 \pm .42$ \\
\hline Pre/Post & 34 & $51.2-59.4$ & $55.23 \pm$ & $2.13 \mp .26$ & \\
\hline Pre/cr & 32 & $27 \cdot 3-29 \cdot 3$ & $28.28 \pm .38$ & $2.20 \mp .27$ & $7.45 \pm .95$ \\
\hline Post/Cr & 30 & $47.8-54.2$ & $51.04 \pm .29$ & $1.59 \pm .21$ & $3.12 \div .40$ \\
\hline Pt/ol & 32 & $62.3-72.8$ & $66.20 \pm .38$ & $2.14 \pm .27$ & $3.24 \pm .41$ \\
\hline $0 \times / 01$ & 33 & $74.5=84.4$ & $78.88 \mp .48$ & $2.77 \pm .34$ & $3.51 \pm .43$ \\
\hline Fe/litu & 32 & $50.5-55.6$ & $53.18 \pm .27$ & $1.53 \pm .19$ & $2.88 \pm .37$ \\
\hline Pe/U1 & 31 & $43.2-47.2$ & $45.24 \pm .25$ & $1.38 \mp .18$ & $3.06 \pm$ \\
\hline $\mathrm{Fe} / \mathrm{Cme}$ & 31 & $96.0-106.3$ & $101.05 \pm .49$ & $2.73 \mp .35$ & $2.70 \pm$ \\
\hline $\mathrm{T} 1 / \mathrm{lu}$ & 31 & $112.6-133.6$ & $126.79 \pm .81$ & $4.50 \pm .57$ & $3.55 \pm$ \\
\hline $\mathrm{TI} / \mathrm{UI}$ & 32 & $200.5-215.4$ & $107.86 \pm .60$ & $3.38 \pm .42$ & $3.13 \mp$ \\
\hline $\mathrm{TI} / \mathrm{Cme}$ & 32 & $225.3-255.9$ & $241.40 \pm 1.41$ & $7.99 \mp 1.00$ & 3.314 \\
\hline Ta/ha & 32 & $84.0-98.7$ & $93.71 \pm .57$ & $3.22 \pm .40$ & $3.44 \pm$ \\
\hline $22 / 12$ & 33 & $74.5=84.7$ & $79.65 \pm .49$ & $2.82 \pm .35$ & $3.54 \pm$ \\
\hline Ta/cine & 33 & $164 \cdot 4-191.3$ & $178.29 \pm 1.18$ & $6.76 \pm .83$ & $3.79 \div$ \\
\hline $\mathrm{Ha} / \mathrm{hiu}$ & 32 & $27.5-24.7$ & $22.73 \mp .19$ & $2.07 \div .13$ & $4.71 \pm$ \\
\hline $\mathrm{He} / \mathrm{UL}_{2}$ & 33 & $18.0-21.3$ & $19.32 \div .14$ & $0.78 \pm .10$ & $4.04 \pm$ \\
\hline Ha/Cane & 33 & $39.6-47.4$ & $43.22 \pm .27$ & $1.53 \pm .19$ & $3.54 \pm$ \\
\hline $\mathrm{Hu} / \mathrm{vI}$ & 39 & $83.2-86.4$ & $84.68 \pm .20$ & $1.26 \mp .14$ & $1.49 \mp .17$ \\
\hline $\mathrm{Ra} / \mathrm{n}$ & 40 & $91.9-97.0$ & $96.29 \mp .06$ & $0.37 \mp .04$ & $0.38 \mp .04$ \\
\hline Ginc/UI & 39 & $42.6-45.9$ & $44.71 \pm .14$ & $0.85 \pm .20$ & $1.90 \pm .22$ \\
\hline$P-1 / 01$ & 40 & $u_{4} \cdot 7-17.3$ & $15.67 \pm .09$ & $0.57 \pm .06$ & $3.64 \pm .47$ \\
\hline$P=2 / i n$ & 40 & $22.6-14.3$ & $13.30 \pm .05$ & $0.33 \mp .04$ & $2.48 \pm .28$ \\
\hline $\mathrm{Pe} / \mathrm{TI}$ & 37 & $39.3-44.8$ & $42.98 \pm .19$ & $1.18 \pm .44$ & $2.81 \pm .33$ \\
\hline & 39 & $71.3-77.6$ & $74.23 \mp .19$ & $1.16 \pm .23$ & $1.56 \pm .18$ \\
\hline & 39 & & $17.98 \pm . .21$ & $0.68 \pm .08$ & $3.78 \pm .43$ \\
\hline
\end{tabular}




\section{Table 2 (cont.) \\ Ratios (per cent)}

Ardea occidentalis

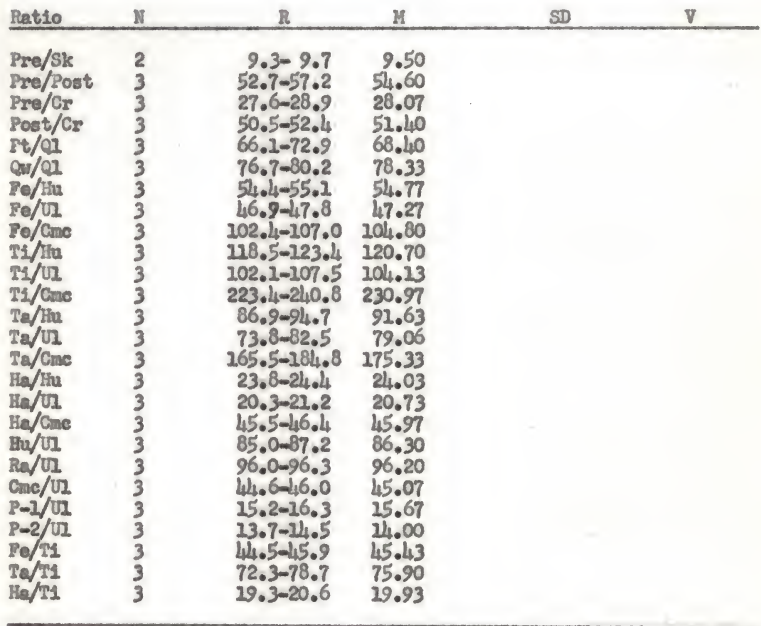




\author{
Table 2 (cont.) \\ Ratios (per cent) \\ Andes cocos
}

\begin{tabular}{|c|c|c|c|c|c|}
\hline Patio & III & $\mathrm{R}$ & u & SD & $\nabla$ \\
\hline Pre/Slk & 4 & $9.8-12.0$ & $20.63 \pm .46$ & $0.92 \pm .36$ & $8.65 \pm 3.06$ \\
\hline Pro/Post & 3 & $56.7-59.3$ & $57.80^{-}$ & & \\
\hline $\mathrm{Pro} / \mathrm{Cr}$ & 4 & $29.0-34.1$ & $30.83 \pm 1.18$ & $2.35 \pm .83$ & $7.62 \geq 2.69$ \\
\hline Post/Cr & 3 & $50.5-52.6$ & $51.43-$ & & \\
\hline Pt/OI & 3 & $58.8-64.5$ & 62.53 & & \\
\hline $\mathrm{cm} / \mathrm{Q} 2$ & 3 & $75.5-81.1$ & 77.47 & & \\
\hline $\mathrm{Fe} / \mathrm{Hu}$ & 2 & $54.2-58.1$ & 56.25 & & \\
\hline $\mathrm{Fe} / \mathrm{OL}$ & 2 & $49 \cdot 3-49 \cdot 9$ & 49.60 & & \\
\hline Fe/Gne & 2 & $211.1-123.6$ & 212.35 & & \\
\hline $\mathrm{Ti} / \mathrm{lha}$ & 2 & $235.8-136.9$ & 136.35 & & \\
\hline$T 1 / 01$ & 3 & $115.7-126.7$ & 116.27 & & \\
\hline TI/Cac & 3 & $259.8-277.3$ & 268.33 & & \\
\hline $\mathrm{Te} / \mathrm{Hu}$ & 2 & $101.2-101.8$ & 101.45 & & \\
\hline Ta/UL & 3 & $85.9-87.7$ & 86.77 & & \\
\hline $\mathrm{Ta} / \mathrm{Gne}$ & 3 & $195.2-20 ? .8$ & 200.27 & & \\
\hline Ho/ hu & 2 & $23.9-25.0$ & 24.45 & & \\
\hline $\mathrm{Ha} / \mathrm{VI}$ & 3 & $20.3-22.0$ & 21.17 & & \\
\hline $\mathrm{Ha} / \mathrm{Cinc}$ & 3 & $48.8=49.1$ & 48.93 & & \\
\hline $\mathrm{Ha} / \mathrm{OI}$ & 2 & $85.0-85.2$ & 85.10 & & \\
\hline Ra/vI & 3 & $92.2-96.6$ & 94.77 & & \\
\hline Cne/OI & 3 & $41.7-44.9$ & 43.33 & & \\
\hline$P-1 / V 1$ & 2 & $25.5-16.0$ & 25.75 & & \\
\hline$P-2 / v 1$ & 3 & $13.5-14.5$ & 14.13 & & \\
\hline $\mathrm{Fe} / \mathrm{TL}$ & 2 & $42.2-42.7$ & 42.55 & & \\
\hline $\mathrm{T} Q / \mathrm{T1}$ & 3 & $73.8-75.2$ & 74.63 & & \\
\hline $\mathrm{Ha} / \mathrm{TI}$ & 3 & $17.6-18.9$ & 18.27 & & \\
\hline
\end{tabular}


Table 2 (cont.)

Rat1os (per cent)

Andea pacifica

\begin{tabular}{|c|c|c|c|c|c|}
\hline Rat1o & I & $\pi$ & M & SD & v \\
\hline Pro/Sk & 1 & 11.2 & 11.20 & & \\
\hline Pre/Post & 2 & $50.9-53.1$ & 52.00 & & \\
\hline $\mathrm{Pre} / \mathrm{Cr}$ & 2 & $27.5-28.4$ & 27.95 & & \\
\hline Post/Cr & 2 & $53.5-514.0$ & 53.75 & & \\
\hline $\mathrm{Pt} / \mathrm{Q1}$ & 2 & $70.5-72.2$ & 72.35 & & \\
\hline 0,102 & 2 & $84.6-84.8$ & 84.70 & & \\
\hline $\mathrm{Fe} / \mathrm{llu}$ & 2 & $48.3-49,0$ & 48.65 & & \\
\hline $\mathrm{Fe} / \mathrm{UI}^{2}$ & 2 & $41.2-41.4$ & 41.30 & & \\
\hline $\mathrm{Fe} / \mathrm{Gme}$ & 2 & $85.0-87.3$ & 86.15 & & \\
\hline $\mathrm{TI} / \mathrm{Hu}$ & 2 & $110.7-2120$ & 20.35 & & \\
\hline $\mathrm{T1} / \mathrm{U}$ & 2 & $92.9-96.0$ & 94.45 & & \\
\hline TI/Care & 2 & $197.0-197.3$ & 197.15 & & \\
\hline $\mathrm{Te} /$ the & 2 & $85.1-87.3$ & 86.20 & & \\
\hline $\mathrm{Te} / \mathrm{UI}$ & 2 & $71.4-74.8$ & 73.10 & & \\
\hline $\mathrm{Ta} / \mathrm{cme}$ & 2 & $251.5-253.7$ & 252.55 & & \\
\hline $\mathrm{Ha} / \mathrm{ki}$ & 2 & $22.7-22.9$ & 22.80 & & \\
\hline He/UI & 2 & $19.3-19.4$ & 19.35 & & \\
\hline $\mathrm{He} / \mathrm{Cme}$ & 2 & $39.9-40.8$ & 40.35 & & \\
\hline Ho/ns & 2 & $84.0-85.7$ & 84.85 & & \\
\hline Re/U1 & 2 & $95.7-96.6$ & 96.15 & & \\
\hline $\mathrm{Cac} / \mathrm{UI}$ & 2 & $47.2-48.7$ & 47.95 & & \\
\hline$P=1 / 01$ & 2 & $17.3-17.6$ & 17.45 & & \\
\hline$P=2 / V I$ & 2 & $15.1-15.4$ & 25.25 & & \\
\hline $\mathrm{Fe} / \mathrm{II}$ & 2 & $43.1-44.3$ & 43.70 & & \\
\hline $\mathrm{TE} / \mathrm{TI}$ & 2 & $76.9-77.9$ & 77.40 & & \\
\hline $\mathrm{H} / \mathrm{II}$ & 2 & $20.2-20.7$ & 20.45 & & \\
\hline
\end{tabular}


Table 2 (cont.)

Ratios (per cent)

Ardee purpures

\begin{tabular}{|c|c|c|c|c|c|}
\hline Ratio & N & $\mathbf{R}$ & M & SD & $\nabla$ \\
\hline Pre/Sk & 3 & 8.6 & 8.60 & & \\
\hline Pre/Post & 6 & $56.9-62.2$ & $60.05 \div .87$ & $2.22 \pm .61$ & $3.53+1.02$ \\
\hline $\mathrm{Pre} / \mathrm{Cr}$ & 6 & $25.9-27.4$ & $26.80 \pm .23$ & $0.57 \pm .16$ & $2.13 \pm$ \\
\hline $\mathrm{Post} / \mathrm{Cr}$ & 6 & $43.2-46.6$ & $44.66 \pm .55$ & $1.35 \pm .39$ & $3.02 \pm .87$ \\
\hline Pt/el & 5 & $62.5-68.2$ & $64.64 \div .99$ & $2.22 \div .70$ & $3.43 \pm 1.09$ \\
\hline $\mathrm{ar} / \mathrm{Q}$ & 5 & $77.3-82.1$ & $79.48 \pm .97$ & $2.17 \pm .69$ & $2.73 \pm .86$ \\
\hline Pe/liu & 6 & $63.4-67.2$ & $65.25 \div .56$ & $2.38 \pm .40$ & $2.11 \div$ \\
\hline $\mathrm{Fe} / \mathrm{UI}$ & 5 & $54.4-58.6$ & $56.74 \div .83$ & $1.86 \div .59$ & $3.28 \div 1.04$ \\
\hline $\mathrm{Be} / \mathrm{Cme}$ & 6 & $119.3-328.2$ & $122.51 \pm 1.59$ & $3.90 \pm 1.13$ & $3.28 \div .92$ \\
\hline $\mathrm{T1/ha}$ & 6 & $117.1-130.8$ & $123.53 \div 2.35$ & $5.76 \pm 1.66$ & $4.66 \pm$ \\
\hline $\mathrm{T} / \mathrm{v}$ & 5 & $103.2-107.5$ & $105.42 \div .92$ & $2.05 \div .65$ & $1.94 \div$ \\
\hline $\mathrm{TI} /$ Grec & 6 & $227.9-246.1$ & $231.90 \div 3.95$ & $9.67 \pm 2.79$ & $4.17 \pm 1.21$ \\
\hline $\mathrm{Te} / \mathrm{Th}$ & 6 & $83.6-91.1$ & $88.02 \pm 1.23$ & $3.01 \div .87$ & $3.43 \div .99$ \\
\hline $\mathrm{Ta} / \mathrm{O}$ & 5 & $73.9-80.1$ & $75.72+1.65$ & $3.69 \pm 1.17$ & $4.87 \pm 1.57$ \\
\hline Ta/Cne & 6 & $155.6-175.3$ & $165.28 \div .90$ & $2.20 \pm .64$ & $1.33 \div .38$ \\
\hline $\mathrm{Ha} / \mathrm{tha}$ & 6 & $32.2 .-33.9$ & $33.13 \div .31$ & $0.77 \div .22$ & $2.32 \div$ \\
\hline Ha/vi & 5 & $27.0-29.9$ & $28.54 \div .54$ & $1.20 \pm .38$ & $4.20 \pm 1.33$ \\
\hline Ha/Cne & 6 & $59.7-65.4$ & $62.23 \div .89$ & $2.19 \div .63$ & $3.52 \pm 1.02$ \\
\hline Hu/U2 & 5 & $83.4=88.4$ & $86.40 \div .98$ & $2.20 \pm .70$ & $2.55 \div$ \\
\hline Ra/Un & 5 & $95.3-96.5$ & $96.02 \pm .21$ & $0.46 \div .15$ & $0.48=$ \\
\hline Guc/us & 5 & $45 \cdot 2-47.5$ & $46.05 \mp .53$ & $1.19 \div .38$ & $2.58 \div$ \\
\hline $\mathrm{P}-1 / 01$ & 5 & $15.5-17.1$ & $16.40 \div .12$ & $0.24=.08$ & $1.465 \div$. \\
\hline$P-2 / 01$ & 5 & $12.1-14.8$ & $23.28 \div .46$ & $1.03 \div .33$ & $7.76 \div 2.46$ \\
\hline $\mathrm{Fo} / \mathrm{Me}$ & 6 & $48.5-56.8$ & $52.93+1.20$ & $2.35 \div .85$ & $5.57 \div 1.61$ \\
\hline $\mathrm{Ta} / \mathrm{mi}$ & 6 & $68.6-77.6$ & $71.34 \div 1.28$ & $3.14 \div .91$ & $4.40 \div 1.27$ \\
\hline $\mathrm{Ha} / \mathrm{Al}$ & 6 & $25.2-28.9$ & $26.87 \pm .57$ & $1.39 \pm .40$ & $5.17 \div 1.49$ \\
\hline
\end{tabular}


Table 2 (cont.)

Ratios (per cent)

Pizherodius pilestus

\begin{tabular}{|c|c|c|c|c|c|}
\hline Ratio & N & R & M & $S D$ & $\nabla$ \\
\hline Pre/sk & 4 & $9.6-10.2$ & $10.13 \pm .13$ & $0.26 \pm .09$ & $2.57 \pm .91$ \\
\hline Pre/Post & 6 & $45.9-49.6$ & $48.07 \pm .67$ & $1.66 \div .06$ & $3.45 \pm .99$ \\
\hline Pre/cr & 6 & $26.2-29.9$ & $27.48 \mp .43$ & $1.05 \mp .30$ & $3.82 \mp 1.10$ \\
\hline Post/Cr & 6 & $56.1-58.3$ & $57.12 \mp .23$ & $0.57 \mp .16$ & $1.00 \mp .29$ \\
\hline $\mathrm{Pt} / \mathrm{Qi}$ & 6 & $67.4-73.2$ & $70.60 \mp .89$ & $2.20 \pm .63$ & $3.12 \mp .90$ \\
\hline aw/ol & 6 & $84.7-88.9$ & $87.00 \mp .69$ & $1.70 \mp .49$ & $1.95 \pm .56$ \\
\hline $\mathrm{Te} / \mathrm{hu}$ & 5 & $60.7-65.2$ & $63.62 \pm .75$ & $2.71 \mp .54$ & $2.69 \mp .85$ \\
\hline $\mathrm{Te} / \mathrm{II}$ & 4 & $46.8-52.7$ & $50.30 \mp 1.25$ & $2.49 \mp .88$ & $4.95 \mp 1.75$ \\
\hline $\mathrm{Fe} / \mathrm{Gme}$ & 6 & $102.5-120.7$ & $107.37+1.16$ & $2.86 \pm .82$ & $2.66 \pm .77$ \\
\hline $\mathrm{TS} / \mathrm{ha}$ & 5 & $236.4-139.9$ & $137.74 \pm .62$ & $1.36 \pm .43$ & $0.99 \pm .32$ \\
\hline 21/uI & 4 & $106.3-210.0$ & $108.53 \mp .66$ & $1.32 \mp .47$ & $1.22 \mp .63$ \\
\hline $\mathrm{TI} / \mathrm{Canc}$ & 6 & $226.9-234.1$ & $231.00 \mp 1.06$ & $2.63 \mp .76$ & $1.24 \pm .33$ \\
\hline Ta/hu & 5 & $95.4-104.9$ & $200.42- \pm 1.57$ & $3.51 \mp 2.21$ & $3.50 \pm 1.21$ \\
\hline Ta/U1 & 4 & $73.6 \mathrm{m1.4}$ & $78.80 \mp 1.81$ & $3.61 \mp 1.28$ & $4.58 \mp 1.62$ \\
\hline Ta/Gane & 6 & $161.1-174.9$ & $168.73 \mp 1.87$ & $4.60 \$ 2.33$ & $2.73 \mp .79$ \\
\hline $\mathrm{Ha} / \mathrm{thu}$ & 5 & $28.5-30.3$ & $29.36 \pm .41$ & $0.92 \pm .29$ & $3.23 \mp$ \\
\hline $\mathrm{Ha} / \mathrm{UL}$ & 4 & $22.0-23.5$ & $22.88 \mp .30$ & $0.59 \mp .21$ & $2.58 \div$ \\
\hline He/Cane & 6 & $48.1-50.3$ & $49.25 \mp .47$ & $1.26 \mp .33$ & $2.36 \div .68$ \\
\hline $\mathrm{Hu} / \mathrm{UL}$ & 3 & $77.1-79.6$ & $78.60^{-.10}$ & & \\
\hline $\mathrm{Ra} / \mathrm{UI}$ & 4 & $94.9-95.7$ & $95.27 \pm .444$ & $0.87 \pm .31$ & $0.91 \pm .32$ \\
\hline Cnc/uI & 4 & $45.7-47.6$ & $46.68 \pm .23$ & $0.45 \pm .16$ & $0.96 \pm .34$ \\
\hline$P-1 / U_{2}$ & 4 & $16.40-17.5$ & $26.88 \div .18$ & $0.35 \mp .12$ & $2.08 \mp .73$ \\
\hline $8-2 / 01$ & 4 & $13.7-14.6$ & $y_{4} \cdot 28 \pm .26$ & $0.51 \pm .18$ & $3.57 \pm 1.26$ \\
\hline $\mathrm{Be} / \mathrm{H}$ & 6 & $44.0-47.9$ & $46.47 \pm .50$ & $1.23 \pm .35$ & $2.65 \pm .76$ \\
\hline $\mathrm{Ta} / \mathrm{HI}$ & 6 & $69.2-75.0$ & $73.05 \mp .85$ & $2.10 \pm .61$ & $2.87 \mp .83$ \\
\hline $\mathrm{Hie} / \mathrm{li}$ & 6 & $20.7-22.2$ & $22.32 \pm .20$ & $0.48 \mp .24$ & $2.25 \pm .65$ \\
\hline
\end{tabular}


Table 2 (cont.)

Ratios (per cont)

Butorides VIrescens Virescens

\begin{tabular}{|c|c|c|c|c|c|}
\hline Rat1o & III & R & s & $S D$ & $\nabla$ \\
\hline Pre/Sk & 26 & $10.5-17.9$ & $21.23 \pm .15$ & $0.75 \pm .10$ & $6.68 \pm .93$ \\
\hline Pre/Post & 25 & $49.1-59.6$ & $53.24 \pm .60$ & $3.01 \pm .43$ & $5.65 \mp .80$ \\
\hline Pre/Cr & 24 & $26.1-32.6$ & $28.38 \pm .27$ & $1.30 \mp .19$ & $4.58 \pm .66$ \\
\hline Post/Cr & 30 & $47.0-57.8$ & $53.89 \pm .56$ & $3.06 \pm .1 .0$ & $5.68 \pm .73$ \\
\hline $\mathrm{Pt} / \mathrm{QI}$ & 32 & $67.2-60.0$ & $74.16 \pm .48$ & $2.74 \pm .34$ & $3.69 \div .46$ \\
\hline $\mathrm{Ou} / \mathrm{O} 2$ & 32 & $81.5=90.8$ & $86.43 \mp .42$ & $2.34=.29$ & $2.72 \pm .34$ \\
\hline $\mathrm{Fe} /$ thu & 29 & $72.1-74.1$ & $71.17 \mp$ & $2.03 \mp$ & $2.05 \div$ \\
\hline $30 / 02$ & 28 & $61.6-68.8$ & $64.45 \pm .28$ & $1.46 \div$ & $2.27 \div$ \\
\hline $\mathrm{Fe} / \mathrm{Gne}$ & 30 & $123.6-138.1$ & $129.90 \mp$ & $3.52 \pm$ & $2.71 \div$ \\
\hline $\mathrm{T1/hu}$ & 26 & $111.3-120.3$ & $225.57 \mp .45$ & $2.30 \div$ & 1.99 \\
\hline $21 / 01$ & 26 & $100.5-107.7$ & $104.42 \div .30$ & $1.96 \pm$ & $1.88 \pm$ \\
\hline T1/Cane & 25 & $200.0-220.3$ & $210.58 \pm 1 . \mathrm{J}_{4}$ & $5.69 \pm$ & $2.70 \pm$ \\
\hline $\mathrm{TQ} / \mathrm{Hu}$ & 32 & $71.1-79.1$ & $74.98 \pm .32$ & $1.79 \pm$ & $2.39 \pm$ \\
\hline Ta/VI & 32 & $64.3-70.0$ & $67.67 \pm$ & $1.39 \pm$ & $2.05 \mp$ \\
\hline Ta/Cne & 32 & $128.7-1 /, 2.2$ & $136.67 \pm .63$ & $3.59 \pm$ & $2.63 \mp$ \\
\hline Ha/thu & 32 & $29 \cdot 0-34.2$ & $32.02 \pm .28$ & $1.04 \pm .13$ & $3.35 \pm .32$ \\
\hline He/ & 32 & $26.2-29.6$ & $27.87 \pm .25$ & $0.86 \pm .11$ & $3.09 \mp .39$ \\
\hline $\mathrm{Hia} / \mathrm{Cnc}$ & 33 & $53.4-51.0$ & $56.45 \mp . .34$ & $1.94 \pm . .24$ & $3.44 \pm .42$ \\
\hline How/vI & 30 & $88.3-92.8$ & $90.32 \pm .22$ & $1.22 \mp .16$ & $2.35 \mp .27$ \\
\hline $\mathrm{Re} / \mathrm{II}$ & 31 & $91.4-96.5$ & $95.34 \pm .14$ & $0.79 \mp .10$ & $0.83 \mp .21$ \\
\hline $\mathrm{Cmo} / \mathrm{UI}$ & 30 & $48.0-51.6$ & $49.60 \mp .18$ & $0.96 \pm .12$ & $1.94 \mp .25$ \\
\hline$P-2 / 01$ & 32 & $16.0-18.6$ & $17.25 \mp .22$ & $1.21 \mp .15$ & $7.06 \mp .88$ \\
\hline $\mathrm{P}-2 / \mathrm{UI}^{2}$ & 31 & $\frac{14.5-16.5}{20}$ & $25.74 \mp .11$ & $0.64 \mp .08$ & $4.21 \pm .53$ \\
\hline $\mathrm{Fe} / \mathrm{M}$ & 26 & $59.6-63.9$ & $61.29 \pm .21$ & $1.22 \mp .17$ & $1.98 \pm .27$ \\
\hline $2 a / 71$ & 27 & $62.2-67.6$ & $64.85 \pm .23$ & $1.21 \pm .16$ & $2.87 \mp .25$ \\
\hline $\mathrm{Ha} / \mathrm{TI}$ & 27 & $21 . .8-27.9$ & $26.73 \pm .15$ & $0.80 \pm .21$ & $2.99 \pm .47$ \\
\hline
\end{tabular}


Table 2 (cont.)

Rattos (per cent)

Butorides striatus

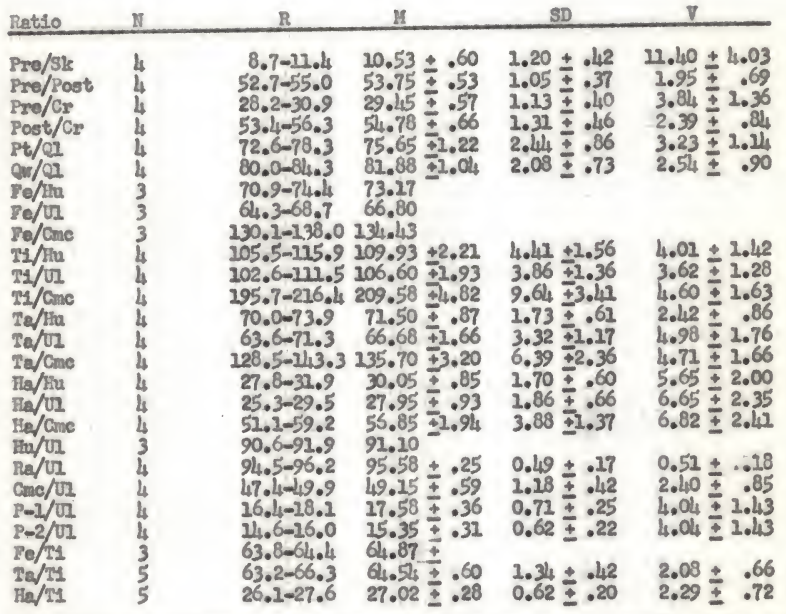


Table 2 (cont.)

Ratios (per cent)

Byythoenus sueiventris

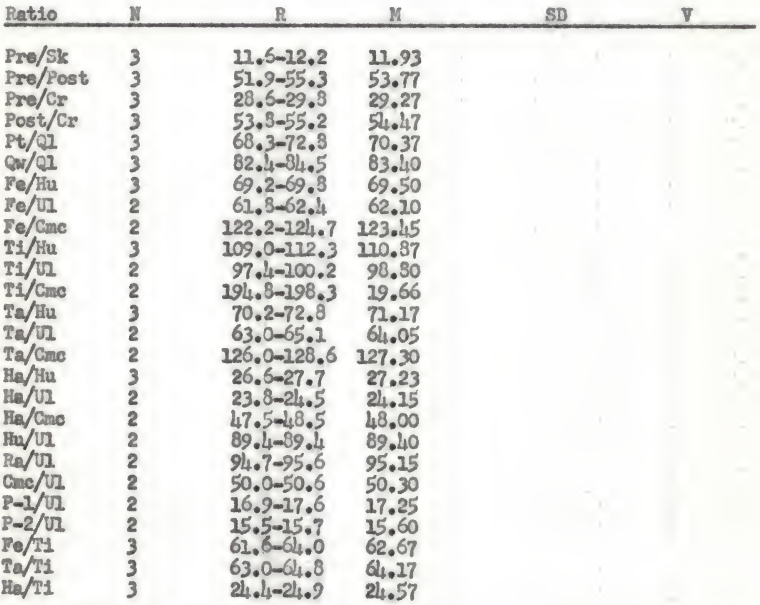


Table 2 (cont.)

Ratios (per cent)

Floride caerules

\begin{tabular}{|c|c|c|c|c|c|}
\hline Ratio & $y$ & $\mathbf{R}$ & $\mathrm{M}$ & SD & $\nabla$ \\
\hline Pre/sk & 16 & $9.1-10.7$ & $10.23+2.03$ & $0.41+.72$ & $4.01 \pm .71$ \\
\hline Pre/Post & 16 & W4.9-49.6 & $47.63 \pm .34$ & $1.36 \mp .24$ & $2.86 \pm .52$ \\
\hline $\mathrm{Pre} / \mathrm{Cr}$ & 16 & $25.7-28.5$ & $27.41 \pm .21$ & $0.85 \pm$ & $3.10 \pm .55$ \\
\hline Post/Cr & 16 & $55.8=61.1$ & $57.56 \pm .34$ & $1.36 \pm$ & $2.36 \pm$ \\
\hline Pt/Q1 & 16 & $70.4-79.5$ & $73.72 \pm .74$ & $2.97 \mp .52$ & $4.03 \pm$ \\
\hline $0 \times / Q 1$ & 16 & $83.6-89.2$ & $86.67 \pm .48$ & $1.92 \pm .34$ & $2.22 \pm$ \\
\hline $\mathrm{Pe} / \mathrm{Hu}$ & 16 & $56.1-59.3$ & $57.58 \pm .35$ & $1.38 \pm .24$ & $2.40 \pm$ \\
\hline $\mathrm{F} / \mathrm{Us}$ & 16 & $47.4-50.8$ & $48.62 \mp .27$ & $1.09 \pm .19$ & $2.23 \pm$ \\
\hline $\mathrm{Pe} / \mathrm{Cme}$ & 16 & $98.7-103.4$ & $100.87 \mp .42$ & $1.66 \pm .29$ & $1.65 \pm$ \\
\hline $\mathrm{T1} / \mathrm{Hu}$ & 16 & $132.6-146.7$ & $139.90 \mp 1.08$ & $4.32 \pm .76$ & $3.09 \pm$ \\
\hline $\mathrm{T1} / \mathrm{U1}$ & 16 & $213.0-125.7$ & $218.61 \pm .78$ & $3.10 \pm .55$ & $2.61 \pm$ \\
\hline $\mathrm{TI} / \mathrm{ame}_{\mathrm{me}}$ & 16 & $227.3-258.8$ & $21.5 .12+2.08$ & $8.33 \pm 1.47$ & $3.40 \pm$ \\
\hline $\mathrm{Ta} / \mathrm{Hu}$ & 16 & $94.9-107.6$ & $102.15 \pm .98$ & $3.92 \pm .69$ & $3.84 \pm .68$ \\
\hline $\mathrm{T} / \mathrm{V}$ & 16 & $80.7-69.5$ & $86.60 \mp .60$ & $2.38 \mp .42$ & $2.75 \pm .49$ \\
\hline $\mathrm{ra} / \mathrm{Cme}$ & 16 & $166.5-185.0$ & $178.95 \mp 2.56$ & $6.25 \pm 1.10$ & $3.49 \pm .62$ \\
\hline $\mathrm{Ha} / \mathrm{Hu}$ & 16 & $27.2-30.3$ & $28.80 \mp .28$ & $1.10 \mp .19$ & $3.82 \mp .67$ \\
\hline $\mathrm{H} / \mathrm{A} / \mathrm{I}$ & 16 & $23.0-26.0$ & $21.42 \mp \pm .31$ & $1.23 \mp .22$ & $5.04 \pm$ \\
\hline $\mathrm{Hi} / \mathrm{Ome}$ & 16 & $47.2-54.2$ & $50.46 \mp .48$ & $1.92 \mp .34$ & $3.80 \mp$ \\
\hline $\mathrm{HW} / \mathrm{UI}$ & 16 & $82.1-86.7$ & $84.81 \pm .34$ & $1.36 \pm .24$ & $1.60 \mp$ \\
\hline Ra/v2 & 16 & $95.3-96.6$ & $95.83 \pm .12$ & $0.49 \pm .09$ & $0.51 \pm$ \\
\hline Gene/U1 & 16 & $46.6-50.6$ & $48.43 \mp .26$ & $1.02 \mp .18$ & $2.21 \pm .37$ \\
\hline$P-1 / U 2$ & 16 & $16.7-18.7$ & $17.79 \mp .15$ & $0.58 \div .10$ & $3.26 \mp .56$ \\
\hline$P-2 / 01$ & 16 & $12.3-15.6$ & $12.93 \pm .20$ & $0.80 \mp .15$ & $6.19 \pm 1.09$ \\
\hline $\mathrm{Pe} / \mathrm{TI}$ & 16 & $39.4-43.4$ & $42.19 \pm .27$ & $1.06 \mp .19$ & $2.57 \pm .45$ \\
\hline $\mathrm{Ta} / \mathrm{TI}$ & 16 & $69.5-75.6$ & $73.04 \mp .49$ & $1.96 \mp .35$ & $2.68 \pm .47$ \\
\hline $\mathrm{Ha} / \mathrm{TL}$ & 16 & 19.1-21.4 & $20.60 \pm .16$ & $0.63 \pm .12$ & $3.06 \pm .54$ \\
\hline
\end{tabular}


Table 2 (cont.)

Ratios (per cent)

Ardeols ralloldes

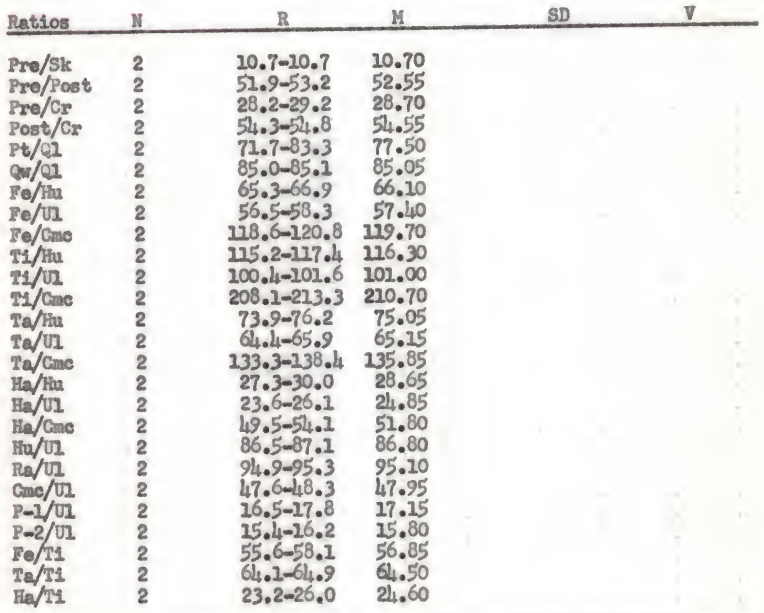




\section{Table 2 (cont.)}

Ratios (per cent)

Andeols bacchus

\begin{tabular}{|c|c|c|c|c|c|}
\hline Ratio & III & $\mathbb{R}$ & I & $S D$ & 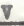 \\
\hline Pre/Sk & 2 & $12.0-12.2$ & 12.10 & & \\
\hline Pre/Post & 2 & $53.7-54.5$ & 54.10 & & \\
\hline Pre/cr & 2 & $29.5-31.2$ & 30.35 & & \\
\hline Post/Cr & 2 & $54.2-58.0$ & 56.10 & & \\
\hline Pt/Q2 & $i$ & & 72.48 & & \\
\hline$e m / 01$ & 2 & $81.3-86.2$ & 83.75 & & \\
\hline $\mathrm{Be} / \mathrm{la}$ & 2 & $66.7=68.7$ & 67.70 & & \\
\hline $\mathrm{Fe} / \mathrm{N}$ & 2 & $56.6-60.1$ & 58.35 & & \\
\hline $\mathrm{Fe} / \mathrm{Gme}$ & 2 & $115.9-117.6$ & 216.75 & & \\
\hline TI/Hu & 2 & $204.4-125.4$ & 221.90 & & \\
\hline Ts/or & 2 & $97.9-100.1$ & 99.00 & & \\
\hline T1/Gne & 2 & $293.0-203.6$ & 198.30 & & \\
\hline $\mathrm{Ta} / \mathrm{Hu}$ & 2 & $70.8-77.2$ & 74.00 & & \\
\hline Ta/ur & 2 & $61.9-65.5$ & 63.70 & & \\
\hline Ta/Gne & 2 & $219.4-136.2$ & 127.80 & & \\
\hline He/thu & 2 & $27.8-28.3$ & 28.05 & & \\
\hline $\mathrm{H} / \mathrm{LI}$ & 2 & $24.1-24.3$ & 24.20 & & \\
\hline $\mathrm{Iia} / \mathrm{Cme}$ & 2 & $46.9-50.0$ & 48.45 & & \\
\hline $\mathrm{Hu} / \mathrm{Or}$ & 2 & $84.9-87.5$ & 86.20 & & \\
\hline $\mathrm{Ra} / \mathrm{oI}$ & $i$ & & 94.62 & & \\
\hline $\operatorname{anc} / \mathrm{UI}_{1}$ & 2 & $48.1-51.9$ & 50.00 & & \\
\hline$P-1 / 2$ & 2 & $16.7-17.2$ & 16.95 & & \\
\hline$P-2 / 01$ & 2 & $16.5-17.6$ & 17.05 & & \\
\hline $70 / \mathrm{si}^{\circ}$ & 2 & $57.7-60.1$ & 58.90 & & \\
\hline $\mathrm{Te} / \mathrm{T1}$ & 2 & $61.9-66.9$ & 64.40 & & \\
\hline $\mathrm{Ha} / \mathrm{TS}$ & 2 & $24.3-24.6$ & 24.45 & & \\
\hline
\end{tabular}




\section{Table 2 (cont.) \\ Rat1os (per cent)}

Ardeols speciose

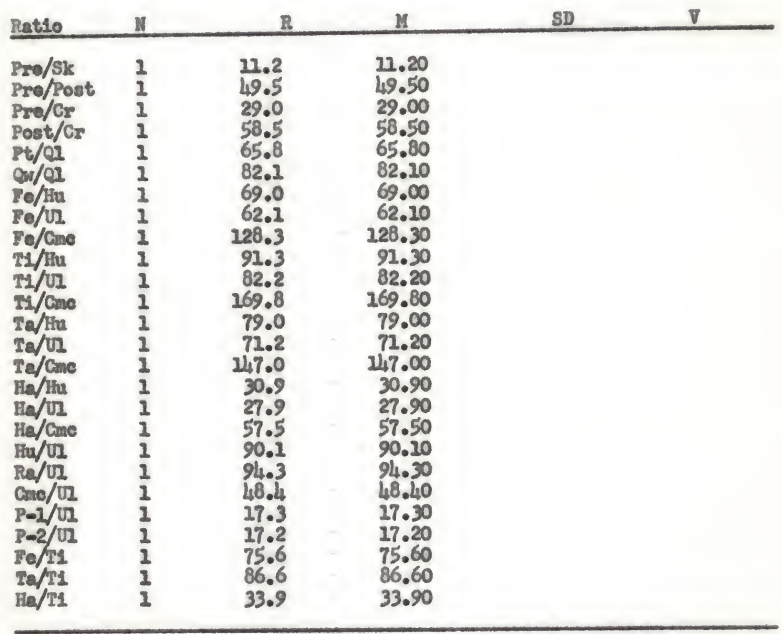


Table 2 (cont.)

Ratios (per cent)

Bubuleus 1 bis

\begin{tabular}{|c|c|c|c|c|c|}
\hline Rat1o & II & R & 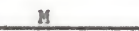 & SD & $v$ \\
\hline $\mathrm{Pre} / \mathrm{Sk}$ & 5 & $10.8-12.9$ & $22.214 \pm .21$ & $0.46 \pm .15$ & $4.09 \pm 1.29$ \\
\hline Pre/Post & 5 & $43.8-47.2$ & $45.78 \mp .73$ & $1.64 \pm .52$ & $3.58 \pm 1.13$ \\
\hline $\mathrm{Pre} / \mathrm{Cr}$ & 5 & $25.9-29.0$ & $27.38 \pm .54$ & $1.20 \mp .38$ & $4.38 \pm 1.39$ \\
\hline Post/Cx & 5 & $57.4-61.7$ & $59.86 \mp .85$ & $1.91 \mp .60$ & $3.19 \mp 1.01$ \\
\hline Pt/QI & 6 & $66.1-78.2$ & $73.22 \pm 1.71$ & $4.29 \mp 1.21$ & $5.72 \mp 1.65$ \\
\hline $0 m / 81$ & 6 & $86.6-91.2$ & $89.20 \mp .73$ & $1.80 \pm .52$ & $2.02 \mp .58$ \\
\hline $\mathrm{Fe} / \mathrm{hu}$ & 5 & $56.3-61.6$ & $58.80 \div .89$ & $2.00 \div .63$ & $3.40 \div 1.08$ \\
\hline $\mathrm{Fe/UI}$ & 5 & $48.1-53.0$ & $50.94 \mp .88$ & $1.97 \mp .62$ & $3.87+1.22$ \\
\hline Fo/Che & 5 & $106.2-115.2$ & $212.00+1.69$ & $3.78 \mp 1.20$ & $3.41+1.08$ \\
\hline $\mathrm{TI} / \mathrm{Hu}$ & 5 & $122.0-137.4$ & $126.08 \div 2.86$ & $6.42 \pm 2.03$ & $5.08+1.61$ \\
\hline $21 / 01$ & 5 & $105.7-108.5$ & $107.22 \pm .45$ & $1.00 \pm .32$ & $0.93 \pm .29$ \\
\hline $\mathrm{T1} / \mathrm{anc}$ & 5 & $232,4-236.0$ & $233.78 \mp .59$ & $1.33 \mp .42$ & 0.57 \\
\hline $\mathrm{Ta} / \mathrm{liu}$ & 5 & $85.8-91.4$ & $88.44 \pm 1.00$ & $2.24 \pm .72$ & $2.53=$ \\
\hline$T 2 / 01$ & 5 & $74.8-78.6$ & $76.54=.70$ & $2.57 \mp .50$ & 2.05 \\
\hline Ta/Cne & 5 & $164.3-170.9$ & $166.90 \pm 1.27$ & $2.85 \pm .90$ & $1.71 \pm .54$ \\
\hline $\mathrm{Ha} / \mathrm{llu}$ & 5 & $28.0-31.0$ & $28.94 \pm 1.08$ & $2.47 \pm .76$ & $8.33 \mp 2.64$ \\
\hline Ro/vi & 5 & $24.2-26.7$ & $25.04 \pm .47$ & $1.06 \pm .34$ & $4.23 \pm 1.314$ \\
\hline $\mathrm{He} / \mathrm{Cme}$ & 5 & $53.0-58.0$ & $54.62 \pm .97$ & $2.17 \pm .69$ & $3.97 \pm 1.26$ \\
\hline $\mathrm{Hu} / \mathrm{UI}$ & 5 & $85.4-87.9$ & $86.56 \pm .94$ & $2.10 \mp .66$ & $2.43 \pm .77$ \\
\hline $\mathrm{Ra} / \mathrm{vI}$ & 5 & $95.7-96.5$ & $96.04 \pm .13$ & $0.30 \mp .09$ & $0.31 \mp .10$ \\
\hline Gne/u & 5 & $45.3-46.1$ & $45.86 \pm .24$ & $0.32 \mp .10$ & $0.70 \pm .22$ \\
\hline$P-1 / 01$ & 5 & $16.6 \mathrm{~m}-18.5$ & $27.42 \pm .31$ & $0.70 \mp .22$ & $4.02 \pm 1.27$ \\
\hline$P-2 / 01$ & 5 & $15.5-16.6$ & $16.10= \pm .20$ & $0.45 \pm .24$ & $2.80 \mp .89$ \\
\hline & 5 & $45.5-49.0$ & $47.48 \mp .65$ & $1.45 \mp .46$ & $3.05 \mp .97$ \\
\hline & $\frac{5}{5}$ & $70.4-72.4$ & $71.40 \pm .42$ & $0.95 \pm .30$ & $1.33 \mp .42$ \\
\hline & & & $23.36 \pm .37$ & $0.82 \mp .26$ & $3.51 \pm 1.12$ \\
\hline
\end{tabular}


Table 2 (cont.)

Ratios (per cent)

Dichromanassa rufescens

\begin{tabular}{|c|c|c|c|c|c|}
\hline Ratio & II & R & $x$ & $S D$ & $v$ \\
\hline Pre/sk & 4 & $9.5-10.3$ & $9,88 \pm .10$ & $0.20 \pm .07$ & $2.02 \pm .71$ \\
\hline Pre/Post & 6 & $47.5-49.8$ & $48.75 \pm .43$ & $1.00 \mp .29$ & $2.05 \pm .59$ \\
\hline $\mathrm{Pre} / \mathrm{Cr}$ & 6 & $27.3-29.1$ & $27.98 \pm .35$ & $0.87 \mp .25$ & $3.13 \mp .90$ \\
\hline Post/Cr & 6 & $55.8-59.3$ & $57.32 \mp .55$ & $1.35 \mp .39$ & $2.36 \pm$ \\
\hline Pt/OI & 6 & $71.3-73.5$ & $72.77 \pm .27$ & $0.66 \pm .19$ & $0.91 \div .26$ \\
\hline $\mathrm{m} / \mathrm{Q} 2$ & 6 & $83.6-86.4$ & $85.40 \mp .40$ & $0.98 \mp .28$ & $1.15 \mp .33$ \\
\hline $\mathrm{Fe} / \mathrm{Hu}$ & 4 & $55.6-57.4$ & $56.53 \mp .23$ & $0.46 \pm .16$ & 0.81 \\
\hline $\mathrm{Fe} / \mathrm{II}$ & 4 & $46.3-47.4$ & $46.97 \pm .37$ & $0.73 \mp .26$ & 1.554 \\
\hline $\mathrm{Fe} / \mathrm{Cme}$ & 4 & $96.4-98.2$ & $97.30 \mp .37$ & $0.74 \mp .26$ & $0.76 \pm .27$ \\
\hline $\mathrm{Ti} / \mathrm{Hu}$ & 5 & $135.9-149.8$ & $\nu_{1} 2.34 \mp 2.65$ & $5.94 \pm 1.88$ & $4.17 \pm 1.32$ \\
\hline T1/U1 & 5 & $112.6-123.1$ & $118.14+1.90$ & $4.26 \pm 1.35$ & $3.61 \pm 1.14$ \\
\hline T1/Cme & 5 & $230.7-258.6$ & $24,5.22 \pm 4.78$ & $10.70 \$ 3.39$ & $4.36 \pm$ \\
\hline Ta/the & 4 & $102,0-120.3$ & $112.58 \pm 3.7$ & $7.41 \pm 2.62$ & $6.58 \pm 2.33$ \\
\hline $\mathrm{Ta} / \mathrm{UI}$ & 4 & $84.45-99 \cdot 3$ & $93.70 \pm 3.23$ & $6.46 \mp 2.28$ & $6.89 \mp 2.43$ \\
\hline Ta/Che & 4 & $175.9-206.0$ & $193.80 \pm 6.47$ & $12.81 \pm 4.53$ & $6.61 \pm 2.34$ \\
\hline $\mathrm{Ha} / \mathrm{lhu}$ & 5 & 22.1623 .3 & $22.66 \pm .23$ & $0.52 \mp .16$ & $2.29 \pm .72$ \\
\hline He/UI & 5 & $18.3-19.1$ & $18.82 \pm .15$ & $0.33 \mp .10$ & $1.75 \pm .55$ \\
\hline $\mathrm{Hla} / \mathrm{Cunc}$ & 5 & $38.1-40.2$ & $39.04 \pm .39$ & $0.88 \mp .28$ & $2.25 \pm .71$ \\
\hline $\mathrm{ma} / \mathrm{OI}$ & 5 & $82.2-84.8$ & $83.04 \pm .45$ & $1.01 \pm .32$ & $1.22 \pm .39$ \\
\hline $\mathrm{Ra} / \mathrm{TI}$ & 4 & $96.2-96.4$ & $96.27 \pm .44 ?$ & $0.84 \mp .30$ & $0.87 \pm .32$ \\
\hline Cne/OI & 5 & $47.6 \times 48.4$ & $48.20 \pm .40$ & $0.90 \mp .28$ & $1.87 \pm .59$ \\
\hline$P=1 / U$ & 5 & $15.6-16.14$ & $16.10 \pm .16$ & $0.35 \pm .21$ & $2.17 \mp .69$ \\
\hline$P-2 / U$ & 5 & $13.44-1 / 4.4$ & $24.00 \pm .17$ & $0.37 \pm .12$ & $2.64 \mp .84$ \\
\hline $\mathrm{Te} / \mathrm{TI}$ & 4 & $37.6-47.8$ & $39.60 \mp .45$ & $1.79 \pm .57$ & $4.52 \mp 1.43$ \\
\hline & 4 & $81.7-84.5$ & $83.03 \pm .67$ & $1.34 \pm .47$ & $1.61 \pm .57$ \\
\hline & 5 & $25.5-16.5$ & $25.94 \pm .29$ & $0.42 \pm .23$ & $2.63 \pm$ \\
\hline
\end{tabular}




\section{Table 2 (cont.) \\ Ratios (per cent)}

Casmerodius albus modestus

\begin{tabular}{|c|c|c|c|c|c|}
\hline Ratio & III & $\mathbf{R}$ & M & $S D$ & $v$ \\
\hline Pre/Sk & 1 & 8.8 & 8.80 & & \\
\hline Pre/Post & $\overrightarrow{2}$ & 53.4 & 53.40 & & \\
\hline Pre/Cr & 1 & 25.8 & 25.80 & & \\
\hline Post/Cr & 1 & 48.4 & 48.40 & & \\
\hline $\mathrm{Pt} / \mathrm{Q}$ & 1 & 58.4 & 58.40 & & \\
\hline $00 / 02$ & $\bar{\imath}$ & $\pi 7.0$ & 77.00 & & \\
\hline $\mathrm{Fe} / \mathrm{Hu}$ & 1 & 53.0 & 53.00 & & \\
\hline ro/un & $i$ & Wh.8 & 44.80 & & \\
\hline $\begin{array}{l}\mathrm{Fe/Cune} \\
\mathrm{T} / \mathrm{Hu}\end{array}$ & 1 & 100.3 & 100.30 & & \\
\hline $\mathrm{T} / \mathrm{No}$ & $\frac{1}{2}$ & 104.2 & 24.00 & & \\
\hline FI/Canc & $i$ & 255.3 & 255.30 & & \\
\hline Te/thu & 1 & 204.8 & 104.80 & & \\
\hline $\mathrm{Ta} / \mathrm{UL}$ & 1 & $88 . ?$ & 88.70 & & \\
\hline $\mathrm{Ta} / \mathrm{Gme}$ & $i$ & 198.5 & 298.50 & & \\
\hline $\mathrm{Ha} / \mathrm{Hu}$ & 2 & 25.4 & 25.40 & & \\
\hline Ha/U & $i$ & 21.5 & 21.50 & & \\
\hline $\mathrm{Ha} / \mathrm{Cm}$. & $\bar{l}$ & 48.2 & 48.20 & & \\
\hline Hay on & 1 & 84.6 & 84.60 & & \\
\hline Ra/uI & 2 & 96.2 & 96.20 & & \\
\hline $\mathrm{Gac} / \mathrm{UI}$ & $\frac{1}{2}$ & 44.7 & 4.70 & & \\
\hline $\begin{array}{l}P-1 / 02 \\
P-2 / U 2\end{array}$ & 2 & 20.3 & $\begin{array}{l}10.50 \\
15.40\end{array}$ & & \\
\hline $\mathrm{Fe} / \mathrm{IL}$ & 2 & 39.3 & 39.30 & & \\
\hline $\mathrm{Ta} / \mathrm{TI}$ & $\overline{2}$ & 77.7 & 77.70 & & \\
\hline $\mathrm{Ha} / \mathrm{T1}$ & 2 & 18.9 & 18.90 & & \\
\hline
\end{tabular}


Table 2 (cont.)

Rat1os (per cent)

Casmerodius albus

\begin{tabular}{|c|c|c|c|c|c|}
\hline Ratio & in & R & M & $\mathrm{SD}$ & $\nabla$ \\
\hline Pre/Sk & 20 & $7.8-9.3$ & $8.43 \div .21$ & $0.48 \div .08$ & $5.69+.90$ \\
\hline Pro/Post & 20 & $52.8-62.6$ & $57.03 \div .62$ & $2.79 \div .14$ & $4.89 \pm .77$ \\
\hline $\mathrm{Pre} / \mathrm{Cr}$ & 20 & $23.0-29.0$ & $25.35 \pm .34$ & $1.51 \div .24$ & $5.96 \div .94$ \\
\hline Post/Cx & 20 & $40.9-47.2$ & $44.46 \pm .31$ & $1.40 \mp .22$ & $3.25 \pm .50$ \\
\hline $\mathrm{Pt} / \mathrm{Q1}$ & 20 & $61.5-71.0$ & $64.56 \pm .57$ & $2.54 \pm .040$ & $3.93 \mp .62$ \\
\hline $0 w / 01$ & 20 & $76.5-83.4$ & $78.77 \pm .55$ & $2.45 \mp .39$ & $3.21 \pm .49$ \\
\hline $\mathrm{Fe} / \mathrm{lhu}$ & 20 & $48.5-58.7$ & $53.39 \mp .44$ & $1.97 \div .31$ & $3.69 \div .58$ \\
\hline $\mathrm{Fo} / \mathrm{UI}$ & 18 & $43.3-46.0$ & $4.62 \mp .18$ & $0.77 \mp .13$ & $1.73 \mp .29$ \\
\hline Je/Gac & 19 & $97.6-103.1$ & $100.32 \div .48$ & $2.08 \div .34$ & $2.07 \div .34$ \\
\hline $\mathrm{T1} / \mathrm{su}$ & 29 & $122.7-151.5$ & $140.86 \pm 1.36$ & $5.92 \pm .96$ & $4.20 \pm .68$ \\
\hline $\mathrm{TI} / \mathrm{N}$ & 27 & $103.4-126.1$ & $177.90 \mp .88$ & $3.62 \div .62$ & $3.07 \mp .53$ \\
\hline TI/Cac & 18 & $2148.4-278.2$ & $264.53 \pm 1.74$ & $7.38 \mp 1.23$ & $2.79 \mp .47$ \\
\hline $\mathrm{Ta} / \mathrm{Hu}$ & 20 & $94.9-110.4$ & $205.59 \pm .59$ & $4.07 \div .64$ & $3.85 \mp .62$ \\
\hline 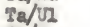 & 18 & $83.2-92.2$ & $88.28 \mp .64$ & $2.73 \mp .46$ & $3.09 \mp .52$ \\
\hline $\mathrm{Ta} / \mathrm{Cne}$ & 19 & $287.2-207.5$ & $198.78 \mp 1.43$ & $6.25+2.01$ & $3.24 \mp .51$ \\
\hline $\mathrm{Ha} / \mathrm{th}$ & 20 & $23.3-27.7$ & $25.19 \pm .21$ & $0.96 \div .15$ & $3.81 \mp .60$ \\
\hline $\mathrm{Ha} / \mathrm{UI}$ & 18 & $19.8-21.7$ & $21.01 \mp .25$ & $0.62 \mp .10$ & $2.95 \div .49$ \\
\hline $\mathrm{Ha} / \mathrm{Cme}$ & 19 & $44.5-51.2$ & $47.27 \mp .36$ & $1.57 \mp .25$ & $3.32 \mp .54$ \\
\hline Ho/VI & 18 & $81.0-85.5$ & $83.51 \pm .25$ & $2.06 \div .18$ & $3.27 \pm .21$ \\
\hline Re/vi & 18 & $90.7-97.5$ & $96.07 \pm .31$ & $1.30 \div .22$ & $1.35 \div .23$ \\
\hline $\mathrm{Cne} / \mathrm{II}$ & 17 & $42.3-46.2$ & $44.48 \div .17$ & $0.72 \div$ & 1.527 \\
\hline$P-1 / 0$ & 18 & $25.0-16.1$ & $15.49 \div .10$ & $0.42 \mp .07$ & $2.71 \div .45$ \\
\hline$P-2 / U 1$ & 18 & $13.2-y_{1} .2$ & $13.77 \div .08$ & $0.35 \div .06$ & $2.54 \div .42$ \\
\hline $\mathrm{Pe} / \mathrm{MI}$ & 19 & $35.8-39.5$ & $37.95 \mp .21$ & $0.90 \mp .15$ & $2.37 \mp .38$ \\
\hline $\mathrm{Te} / \mathrm{TI}$ & 19 & $71.2-77.4$ & $74.87 \div .42$ & $1.79 \div .29$ & $2.39 \div .39$ \\
\hline $\mathrm{He} / \mathrm{T1}$ & 19 & $16.0-19.2$ & $17.93 \mp .17$ & $0.75 \mp .12$ & $4.18 \div .68$ \\
\hline
\end{tabular}


Table 2 (cont.)

Ratios (per cant)

Egretta garzette

\begin{tabular}{|c|c|c|c|c|c|}
\hline Ratio & NI & $n$ & III & SD & $\nabla$ \\
\hline & 3 & $\begin{array}{r}9.6-10.1 \\
48.5-50.9\end{array}$ & & & \\
\hline $\begin{array}{l}\text { Pre/Post } \\
\text { Pre/Cr }\end{array}$ & 4 & $\begin{array}{l}48.5-50.9 \\
27.2-28.7\end{array}$ & $\begin{array}{l}49.80 \pm \\
27.73\end{array}$ & $1.28 \pm .45$ & $2.57 \pm .92$ \\
\hline Post/Cx & 3 & $55.6-56.4$ & 56.10 & & \\
\hline $\mathrm{Pt} / \mathrm{QI}$ & 4 & $69,3-73.5$ & $71.75 \pm .97$ & $1.93 \pm .68$ & $2.69 \pm .95$ \\
\hline $0 w / Q 2$ & $\overrightarrow{4}$ & $86.7-88.6$ & $87.30 \mp .45$ & $0.90 \mp .32$ & $1.03 \mp .36$ \\
\hline $\mathrm{Fe} / \mathrm{th}$ & 6 & $55.5-60.9$ & $57.68 \pm .88$ & $2.17 \pm .53$ & $3.76 \mp 1.08$ \\
\hline $\mathrm{F} / \mathrm{NI}$ & 5 & $46.2-52,1$ & $47.94 \mp 1.09$ & $2.14 \pm$ & $5.09+1.61$ \\
\hline $\mathrm{Fe} / \mathrm{Cue}$ & 5 & $201.3-208.6$ & $104.20+2.3 h_{4}$ & $3.01 \div .95$ & $2.89 \pm .91$ \\
\hline $\mathrm{TI} / \mathrm{Hu}$ & 4 & $129.2-157.3$ & 143.1374 .79 & $9.57+3.38$ & $6.69 \mp 2.36$ \\
\hline $\mathrm{TI} / \mathrm{I}$ & 4 & $217.9-127.3$ & $122.23 \mp 2.28$ & $4.55+1.61$ & $3.72 \pm 2.31$ \\
\hline $\mathrm{TI} / \mathrm{Cme}$ & 4 & $21,0.7-269.6$ & $258.67 \mp 6.43$ & $12.85+74.54$ & $4.97+1.76$ \\
\hline Ta/titu & 5 & $93.6-103.9$ & $101.06 \pm 1.75$ & $3.91+1.214$ & $3.87 \mp 1.22$ \\
\hline $\mathrm{Ta} / \mathrm{UL}$ & 5 & $78.9-87.6$ & $83.50 \pm 1.65$ & $3.70 \pm 2.17$ & $4.43 \mp 1.40$ \\
\hline $\mathrm{Ta} / \mathrm{Ganc}$ & 5 & $173.0-189,0$ & $181.38 \mp 2.66$ & $5.95 \pm 1.88$ & $3.28-1,04$ \\
\hline $\mathrm{Ha} / \mathrm{Hu}$ & 5 & $25.2-27.0$ & $26.00 \pm .34$ & $0.77 \pm .24$ & $2.96 \mp .94$ \\
\hline He/v & 5 & $20,2-23.6$ & $21.50 \mp .56$ & $1.26 \mp .40$ & $5.86 \mp 1.85$ \\
\hline $\mathrm{Ha} / \mathrm{Cnc}$ & 5 & $44.2-49.2$ & $46.72 \pm .82$ & $1.83 \mp .58$ & $3.92 \pm 1.24$ \\
\hline $\mathrm{Fu} / \mathrm{g}$ & 5 & $75.9-87.4$ & $82.70 \mp 1.88$ & $4.22 \pm 1.34$ & $5.20 \pm 1.61$ \\
\hline $\mathrm{Ra} / \mathrm{uI}$ & 5 & $95.2-96.6$ & $95.86 \pm .29$ & $0.65 \pm .21$ & $0.69 \pm .22$ \\
\hline $\mathrm{Canc} / \mathrm{J}$ & & $45.2-47.9$ & $46.02 \mp .53$ & $1.15 \pm .36$ & $2.50 \mp .79$ \\
\hline$P=1 / \Omega$ & 4 & $16.3-17.6$ & $16.78 \mp .26$ & $0.52 \pm .18$ & $3.10 \mp 1.10$ \\
\hline$P=2 / U I$ & 4 & $25.1-16.9$ & $15.60 \pm .44$ & $0.87 \mp .31$ & $5.58 \mp 1.97$ \\
\hline $\mathrm{F} \times / \mathrm{TI}$ & & $37.7-44.1$ & $40.48 \mp .39$ & $0.78 \mp .28$ & $1.93 \mp .68$ \\
\hline $\mathrm{Ta} / \mathrm{TI}$ & 4 & $66.9-74.6$ & $69.93+1.66$ & $3.32 \mp 1.17$ & $4.75 \mp 1.68$ \\
\hline $\mathrm{Ha} / \mathrm{al}$ & 4 & $17.1-19.7$ & $18.10 \pm .63$ & $1.25 \mp .44$ & $6.91 \mp 2.44$ \\
\hline
\end{tabular}


Table 2 (cont.)

Ratios (per cent)

Errotta Internedia internedia

\begin{tabular}{|c|c|c|c|c|c|}
\hline Rat1o & $N$ & $R$ & $M$ & SD & $\nabla$ \\
\hline Pre/Sk & 1 & 20.8 & 10.80 & & \\
\hline Pre/Post & 2 & 52.8 & 51.80 & & \\
\hline $\mathrm{Pre}_{\mathrm{T}} / \mathrm{Cr}$ & $\vec{\imath}$ & 28.4 & 23.40 & & \\
\hline Post/Cr & $i$ & 54.8 & 54.80 & & \\
\hline $\mathrm{Pt} / \mathrm{QI}$ & 2 & 63.9 & 63.90 & & \\
\hline ow/oz & 2 & 83.5 & 83.50 & & \\
\hline $\mathrm{Fe} / \mathrm{lhu}$ & $i$ & 53.0 & 53.00 & & \\
\hline $\mathrm{Fe} / \mathrm{VI}$ & $\bar{I}$ & W. 0 & 44.00 & & \\
\hline $\mathrm{Fe} / \mathrm{Cme}$ & $\bar{I}$ & 96.3 & 96.30 & & \\
\hline 21/Hu & 1 & 240.5 & $v_{4} 0.50$ & & \\
\hline$x:$ /UI & $\overrightarrow{2}$ & 216.9 & 170.90 & & \\
\hline $\mathrm{xH} / \mathrm{Cmc}$ & I & 255.6 & 255.60 & & \\
\hline Ta/hu & $\vec{I}$ & 204.1 & 104.10 & & \\
\hline $\mathrm{Ta} / \mathrm{UI}$ & $i$ & 86.5 & 86.50 & & \\
\hline Ta/cane & $\overline{1}$ & 189.3 & 189.30 & & \\
\hline $\mathrm{Ha} / \mathrm{lin}$ & 1 & 28.9 & 28,90 & & \\
\hline $\mathrm{H} / \mathrm{UI}$ & 1 & 24.0 & 24.00 & & \\
\hline $\mathrm{Hl} / \mathrm{Cmc}$ & $\overline{2}$ & 52.6 & 52.60 & & \\
\hline $\mathrm{Hu} / \mathrm{VI}$ & $i$ & 83.2 & 83.20 & & \\
\hline $\mathrm{Re} / \mathrm{vI}$ & 1 & 96.0 & 96.00 & & \\
\hline $\mathrm{Cmc} / \mathrm{NI}$ & 1 & 45.7 & 45.70 & & \\
\hline$P-2 / v 1$ & 1 & 15.8 & 15.80 & & \\
\hline$P-2 / U 1$ & 2 & 14.0 & $V_{1.00}$ & & \\
\hline $\mathrm{Fo} / \mathrm{ML}$ & 1 & 37.7 & 37.70 & & \\
\hline $\mathrm{Te} / \mathrm{T1}$ & 1 & 74.0 & 74.00 & & \\
\hline $\mathrm{He} / \mathrm{TI}$ & 1 & 20.6 & 20.60 & & \\
\hline
\end{tabular}


Table 2 (cont.)

Ratios (per cent)

Lencophoye thuis

\begin{tabular}{|c|c|c|c|c|c|}
\hline Ratio & If & $\mathrm{R}$ & $M$ & SD & $\mathbf{v}$ \\
\hline Pre/Sls & 12 & $9.2-11.1$ & $9.88 \pm .19$ & $0.66 * .14$ & $6.68 \div 1.36$ \\
\hline Pre/Post & 12 & $45.5-47 . ?$ & $48.17 \pm .62$ & 2. $y_{4} \pm .44_{4}$ & $4.44 \pm .91$ \\
\hline Pre/Cr & II & $27.0-29.8$ & $28.12 \pm .26$ & $0.86 \pm$ & $3.06 \pm$ \\
\hline Post/Cr & 11 & $55.7-60.1$ & $58.17 \pm .48$ & $1.62 \pm$ & $2.77 \pm$ \\
\hline $\mathrm{Pt} / \mathrm{QI}$ & 21 & $66.4-81.5$ & $76.21 \pm 1.35$ & $4.47 \pm$ & $5.87 \overline{4}$ \\
\hline$Q m / Q 1$ & II & $82.5-89.5$ & $86.20 \mp .62$ & $2.04 \pm$ & $2.37 \mp$ \\
\hline $\mathrm{Fe} /$ liu & 27 & $55.4-60.0$ & $57.37 \mp .50$ & $1.65 \pm$ & $2.88 \pm$ \\
\hline $\mathrm{Pe} / \mathrm{UI}$ & 22. & $46.4-50.2$ & $47.97 \pm .34$ & $1.14 \pm .24$ & $2.38 \pm$ \\
\hline $\mathrm{Fe} / \mathrm{Cne}$ & 11 & $96.3-207.6$ & $102.24 \pm 1.03$ & $3.43 \pm .73$ & $3.35 \mp .072$ \\
\hline I1/Hu & 10 & $137.0-11,5.0$ & $140.68 \pm 1.12$ & & .56 \\
\hline $\mathrm{T1} / \mathrm{vI}$ & 21 & $213.9-122.6$ & $217.92 \pm$ & $2.88 \pm$ & $2.46 \pm$ \\
\hline$T 1 / \operatorname{Cac}$ & 21 & $238.9-270.4$ & $249.73 \pm 2.60$ & $9.31 \mp 1.99$ & $3.73 \mp$ \\
\hline $\mathrm{TE} / \mathrm{Hu}$ & 9 & $101.4-105.1$. & $102.71 \mp .89$ & $2.66 \pm .53$ & $2.61 \pm$ \\
\hline $\mathrm{T} / \mathrm{UL}$ & 20 & $83.5-93.9$ & $86.42 \pm .92$ & $2.94 \mp .66$ & $3.40 \mp$ \\
\hline $\mathrm{Ta} / \mathrm{Cnc}$ & 20 & $177.3-206.3$ & $184.73 \mp 2.53$ & $8.06 \mp 1.80$ & $4.36 \mp$ \\
\hline He/liu & 10 & $23.4-29.0$ & $26.66 \pm .48$ & $1.52 \pm .34$ & $5.70 \mp 1.27$ \\
\hline $\mathrm{Ha} / \mathrm{OI}$ & 211 & $21.2-24.8$ & $22.40 \mp .22$ & $0.74 \mp$ & $3.30 \mp .70$ \\
\hline $\mathrm{Ha} / \mathrm{Canc}$ & 11 & $45.2-51.4$ & $47.74 \pm .72$ & $2.37 \pm$ & 2.06 \\
\hline $\mathrm{H} w / \mathrm{V}$ & บ1 & $82.2-84.5$ & $83.26 \mp .37$ & $1.22 \mp$ & $1.47 \mp$ \\
\hline $\mathrm{R} a / \mathrm{J}$ & 12 & $95.3-57.1$ & $96.11 \mp .28$ & $0.97 \mp$ & $1.01 \overline{4}$ \\
\hline $\mathrm{Crac} / \mathrm{UI}$ & 12 & $45.3-4+8.4$ & $46.94 \pm .34$ & $1.12 \pm$ & $2.49 \mp$ \\
\hline $\mathrm{P}-1 / \mathrm{U}$ & 12 & $15.7-17.0$ & $16.29 \pm .13$ & $0.45 \div .09$ & $2.76 \div$ \\
\hline $\mathrm{P}-2 / \mathrm{UI}$ & 22 & $24.3-15.6$ & $14.93 \pm .13$ & $0.45 \mp .09$ & $3.01 \mp .61$ \\
\hline $\mathrm{Fe} / \mathrm{TI}$ & 12 & $39.2-43.2$ & $42.05 \pm .40$ & $1.39 \pm .28$ & $3.39 \mp .69$ \\
\hline Ta/ 11 & 211 & $69.9-80.2$ & $74.00 \mp .05$ & $2.82 \mp .60$ & $3.81 \mp .81$ \\
\hline & 12 & $17.5-21.2$ & $19.15 \pm .26$ & $0.89 \pm .18$ & $4.65 \pm .95$ \\
\hline
\end{tabular}


Table 2 (cont.)

Ratios (per oent)

Hydranassa tricolor

\begin{tabular}{|c|c|c|c|c|c|}
\hline Rat1o & II & B & n & $S D$ & $\nabla$ \\
\hline Pro/Sk & 14 & $8.2-9.2$ & $8.79 \pm .14$ & $0.52 \pm .10$ & $5.92 \pm 1.12$ \\
\hline Pre/Post & 26 & $49.8-58.5$ & $55.26 \pm .66$ & $2.62 \div .146$ & $4.74 \pm .84$ \\
\hline Pre/Cr & 15 & $24.5-28.2$ & $26.91 \mp .29$ & $3.214 \pm .21$ & $4.24 \mp .77$ \\
\hline Post/Cr & $\sqrt{25}$ & $44.8-52.7$ & $48.80 \div .56$ & $2.27 \div .40$ & $4.45 \div$ \\
\hline $\mathrm{Pt} / \mathrm{Q} 1$ & $\widetilde{I}_{4}$ & $71.5-79.7$ & $74.87 \div .57$ & $2.15 \div .42$ & 2.87 \\
\hline $00 / 03$ & 16 & $71.5-79.7$ & $92.02 \div .79$ & $3 . u_{1} \neq .55$ & $3.41 \div .60$ \\
\hline $\mathrm{Fe} / \mathrm{Hu}$ & 17 & $57.6-60.0$ & $58.95 \mp .30$ & $1.22 \pm .21$ & $2.07 \mp .35$ \\
\hline $\mathrm{Fe} / \mathrm{UI}$ & 15 & $48.4-51.0$ & $49.76 \pm .22$ & $0.87 \mp .26$ & $1.75 \pm .32$ \\
\hline $\mathrm{Fe} / \mathrm{Gne}$ & 16 & $97.6-105.3$ & $101.55 \div .70$ & $2.81 \mp .50$ & $2.77 \div .49$ \\
\hline $\mathrm{T1} / \mathrm{Hu}$ & 15 & $124.9-146.0$ & $137.47 \pm 1.39$ & $5.36 \div .98$ & 3.90 \\
\hline $21 / 01$ & य. & $105.3-121.8$ & $215.91 \pm 1.42$ & $5.30 \pm 2.00$ & $4.57 \pm$ \\
\hline $\mathrm{TI} / \mathrm{Cme}$ & 15 & $213.5-257.6$ & $236.91+2.84$ & $11.01+2.02$ & 4.65 \\
\hline $\mathrm{Te} / \mathrm{Hu}$ & य & $93.3-108.3$ & $103.32 \pm 1.43$ & $5.36 \pm 1.01$ & $5.19 \mp .98$ \\
\hline $\mathrm{T} / \mathrm{VI}$ & 13 & $77.9-92.1$ & $87.14 \pm 1.36$ & $4.92 \pm .96$ & $5.65 \pm 1.21$ \\
\hline $\mathrm{T} 2 / \mathrm{dane}$ & I4 & $161.3-189.9$ & $178.10+2.16$ & $9.20 \mp 1.74$ & $5.17 \mp .98$ \\
\hline $\mathrm{Ha} / \mathrm{Hu}$ & 16 & $27.1-29.7$ & $28.39 \mp .26$ & $1.03 \mp .18$ & $3.63 \div .64$ \\
\hline $\mathrm{RO} / \mathrm{OI}$ & 25 & $23.0-25.4$ & $24.03 \mp .22$ & $0.85 \mp .16$ & $3.54 \pm .66$ \\
\hline $\mathrm{H}$ la/ane & 16 & $47.8-52.5$ & $48.94=.40$ & $2.59 \mp .28$ & $3.25 \div .57$ \\
\hline $\mathrm{Hu} / \mathrm{WI}$ & 25 & $82.9-85.5$ & $84.37 \pm .14$ & $0.53 \mp .10$ & $0.63 \mp .11$ \\
\hline $\mathrm{Ra} / \mathrm{UI}$ & 15 & $94.9-96.5$ & $95.65 \div .20$ & $0.79 \mp .44$ & $0.83 \mp .15$ \\
\hline Gine/Ul & 15 & $47.8-50.9$ & $48.89 \mp .24$ & $0.93 \mp .17$ & $1.90 \div .35$ \\
\hline$P-1 / U I$ & 15 & $16.4-18.0$ & $17.58 \pm .11$ & $0.42 \pm .07$ & $2.33 \div .43$ \\
\hline$P-2 / 01$ & 15 & $12.6-15.4$ & $13.29 \mp .17$ & $0.66 \mp .12$ & $4.97 \div .91$ \\
\hline $\mathrm{Fe} / \mathrm{TL}$ & 25 & $40.8-46.1$ & $42.92 \mp .38$ & $1.48 \div .27$ & $3.45 \div .63$ \\
\hline $\mathrm{T} / \mathrm{pI}$ & $\mathcal{I}_{4}$ & $70.0-77.7$ & $75.20 \mp .53$ & $1.98 \mp .37$ & \\
\hline $\mathrm{H} / \mathrm{a} / \mathrm{T}$ & 15 & $19.0-22.6$ & $20.72 \mp .25$ & $0.97 \mp .18$ & $4.68 \div$ \\
\hline
\end{tabular}


Table 2 (cont.)

Ratios (per cent)

\section{Syrigme sibllatrix}

\begin{tabular}{|c|c|c|c|c|c|}
\hline Pat1o & NI & R & $\pi$ & SD & $v$ \\
\hline Pre/Sk & 1 & 11.3 & 12.30 & & \\
\hline Pre/Post & 1 & 46.1 & 46.10 & & \\
\hline Pre/cr & $i$ & 27.2 & 27.20 & & \\
\hline Post/Cr & 1 & 59.0 & 59.00 & & \\
\hline Pt/Q1 & 1 & 72.3 & 72.30 & & \\
\hline $0 w / Q 1$ & 1 & 94.9 & 94.90 & & \\
\hline $\mathrm{Fo} / \mathrm{Hu}$ & 1 & 54.1 & 54.10 & & \\
\hline $\mathrm{Fe} / \mathrm{UI}$ & 1 & 45.3 & 45.30 & & \\
\hline $\mathrm{Fe} / \mathrm{Cme}$ & 1 & 93.7 & 93.70 & & \\
\hline $\mathrm{TI} / \mathrm{Hu}$ & 1 & 226.5 & 126.50 & & \\
\hline T1/01 & 1 & 97.7 & 97.70 & & \\
\hline II/Cne & 1 & 201.9 & 201.90 & & \\
\hline $\mathrm{Te} / \mathrm{Hu}$ & 1 & 85.1 & 85.10 & & \\
\hline $\mathrm{Te} / \mathrm{UI}$ & 1 & 71.3 & 73.30 & & \\
\hline $\mathrm{Ta} / \mathrm{Cme}$ & 1 & 147.5 & $\nu_{4} 7.50$ & & \\
\hline $\mathrm{He} / \mathrm{Hu}$ & 1 & 27.0 & 27.00 & & \\
\hline $\mathrm{Ha} / \mathrm{UI}$ & $\bar{\imath}$ & 22.7 & 22.70 & & \\
\hline $\mathrm{Ha} / \mathrm{Cme}$ & 1 & 46.9 & 46.90 & & \\
\hline How/OI & 2 & 83.8 & 83.80 & & \\
\hline Ra/v1 & 1 & 95.7 & 95.70 & & \\
\hline $\mathrm{Cne} / \mathrm{OI}$ & 1 & 48.4 & 48.40 & & \\
\hline $\mathrm{P}-1 / \mathrm{V}$ & 1 & 17.5 & & & \\
\hline $\mathrm{P}-2 / \mathrm{VI}$ & 1 & I1. 8 & 14.80 & & \\
\hline $\mathrm{re} / \mathrm{Hi}$ & $\overrightarrow{1}$ & 46.4 & 46.40 & & \\
\hline $\mathrm{ra} / \mathrm{T1}$ & 1 & 73.0 & 73.00 & & \\
\hline $\mathrm{H} / \mathrm{Tl}$ & 1 & 23.2 & 23.20 & & \\
\hline
\end{tabular}


Table 2 (cont.)

Ratios (per cent)

Nyeticorax nycticorex nycticorex

\begin{tabular}{|c|c|c|c|c|c|}
\hline Ratio & II & $R$ & II & $S D$ & $\boldsymbol{\nabla}$ \\
\hline Pre/Sk & 4 & $12.7-13.1$ & $12.85 \pm .09$ & $0.17 \pm .06$ & $1.32 \pm .47$ \\
\hline Pre/Post & 5 & $46.4-53.0$ & $48.00 \pm 1.26$ & $2.82 \pm 2.00$ & $5.88 \mp 2.08$ \\
\hline Pre/Cy & 4 & $30.0-31.6$ & $30.73 \pm .30$ & $0.60 \mp .21$ & $1.95 \pm .69$ \\
\hline Post/Cr & 4 & 56.6066 .9 & $63.85 \pm 2.45$ & $4.89 \pm 1.73$ & $7.66 \pm 2.71$ \\
\hline $\mathrm{Pt} / \mathrm{Qi}$ & 5 & $59.2-65.8$ & $62.54 \geq 1.31$ & $2.93 \pm .93$ & $4.69 \pm 2.48$ \\
\hline $\mathrm{Om} / \mathrm{OL}$ & 4 & $78.7=82.8$ & $80.58 \pm .98$ & $1.95 \pm .69$ & $2.42 \pm .86$ \\
\hline 7e/fu & 4 & $63.4-66.7$ & $64.85 \pm .69$ & $1.37 \mp .48$ & $2.11 \mp .75$ \\
\hline $\mathrm{re} / \mathrm{UI}$ & 4 & $56.6-59.3$ & $57.63 \pm .52$ & $1.04 \mp .37$ & 1.80 \\
\hline $\begin{array}{l}\text { Fe/ Gine } \\
\mathrm{T1} / \text { lihs }\end{array}$ & 4 & $116.0-123.2$ & $119.65 \pm 1.47$ & $2.94 \pm 1.04$ & $2.46 \div .87$ \\
\hline T1//hu & $\frac{4}{4}$ & $\begin{array}{c}107.8-112.4 \\
96.3-98.8\end{array}$ & $109.85 \pm .95$ & $1.90 \mp .67$ & $1.73 \div .61$ \\
\hline II/Cane & & $\begin{array}{c}96.3-98.8 \\
196.8-206.7\end{array}$ & $\begin{array}{r}97.55 \div .52 \\
202.65+2.25\end{array}$ & $\begin{array}{l}1.04 \\
4.50 \div 1.59\end{array}$ & $\begin{array}{l}1.07 \div .37 \\
2.22 \div .78\end{array}$ \\
\hline $\mathrm{Te} / \mathrm{Hu}$ & 4 & $67.9-72.8$ & $70.50 \pm 1.01$ & $2.01 \pm .72$ & $2.85+1.01$ \\
\hline Talon & 4 & $60.7-64.8$ & $62.63 \mp .81$ & $1.62 \pm .57$ & $2.59 \mp .92$ \\
\hline $\mathrm{Te} / \mathrm{Cur}$ & 4 & $126.3-133.4$ & $130.05 \pm 1.48$ & $2.96 \mp 1.05$ & $2.28 \mp .81$ \\
\hline $\mathrm{He} / \mathrm{Hu}$ & 4 & 23.8 & $24.70 \pm .53$ & $1.05 \pm .37$ & $4.25 \mp 1.50$ \\
\hline Havon & 4 & $21.3-22.3$ & $21.93 \pm .12$ & $0.24 \mp .08$ & $1.09 \pm .39$ \\
\hline $\mathrm{He} /$ Cane & 4 & $44.7-46.9$ & $45.55 \pm .48$ & $0.96 \pm .34$ & $2.27 \pm .75$ \\
\hline $\mathrm{Haw}$ UI & 4 & $87.9=89.4$ & $88.85 \pm .33$ & $0.66 \pm .23$ & $0.74 \mp .26$ \\
\hline $\mathrm{Ra} / \mathrm{VI}$ & 4 & $95.2-96.0$ & $95.62 \mp .45$ & $0.89 \pm .31$ & $0.93 \pm .33$ \\
\hline $\begin{array}{l}\mathrm{Canc} / \mathrm{U} \\
\mathrm{P}-\mathrm{I} / \mathrm{\Omega}\end{array}$ & 4 & $\begin{array}{l}46.9-49.5 \\
15.5-17.5\end{array}$ & $48.18 \div .57$ & $1.14 \pm .40$ & $2.37 \div .84$ \\
\hline$P=2 / 01$ & 4 & $\begin{array}{l}15.5-17.5 \\
13.9-15.3\end{array}$ & $\begin{array}{l}16.38 \pm .40 \\
1.65 \pm .35\end{array}$ & $\begin{array}{l}0.79 \div .28 \\
0.70 \div .25\end{array}$ & $\begin{array}{l}4.82+1.70 \\
4.78+1.69\end{array}$ \\
\hline Fe/r1 & 4 & $57.6-60.9$ & $59.05 \div .86$ & $1.71 \mp .60$ & $2.90 \$ 1.02$ \\
\hline & 4 & $62.7-66.5$ & $64.20 \pm .86$ & $1.72 \mp .60$ & $2.68 \mp .95$ \\
\hline & 4 & $22.1-22.9$ & $22.47 \pm .28$ & $0.55 \pm .29$ & $2.23 \pm .79$ \\
\hline
\end{tabular}


Table 2 (cont.)

Ratios (per cent)

Nreticorax nycticorax hoactis

\begin{tabular}{|c|c|c|c|c|c|}
\hline Ratio & $n$ & 8 & $M$ & SD & v \\
\hline Pre/sk & 40 & $12.0-13.9$ & $13.08 \pm .07$ & $0.47 \pm .05$ & $3.59 \pm .40$ \\
\hline Pre/Post & 40 & $43.0-51.1$ & $47.03 \pm$ & $1.66 \pm .19$ & $3.53 \pm .39$ \\
\hline Pre/cr & 39 & $29.2-32.3$ & $30.85 \div .19$ & $1.17 \pm .13$ & $3.79 \pm$ \\
\hline Post/Cx & 36 & $60.0-68.8$ & $65.68 \pm .37$ & $2.22 \pm .26$ & $3.38 \pm$ \\
\hline Pt/OL & 39 & $59.8-68.8$ & $64.36 \pm .38$ & $2.39 \pm .27$ & $3.71 \pm$ \\
\hline $0 m / 02$ & 41. & $75.1-86.7$ & $81.12 \pm .45$ & $2.87 \pm .32$ & $3.54 \pm$ \\
\hline $\mathrm{Fe} / \mathrm{Hu}$ & 33 & $58.8=67.4$ & $64.81 \pm .32$ & $1.83 \mp .23$ & $2.82 \pm$ \\
\hline $\mathrm{Pe} / \mathrm{UL}$ & 31 & $56.4-62.2$ & $59.26 \mp .27$ & $1.52 \pm .19$ & $2.56 \pm$ \\
\hline Fe/Cne & 32 & $112.2-125.2$ & $217.81 \pm$ & $3.24 \pm .41$ & $2.75 \pm$ \\
\hline $\mathrm{TI} / \mathrm{Hu}$ & 30 & $96.0-111.9$ & $208.96 \mp .71$ & $3.91 \mp .50$ & $3.59 \pm$ \\
\hline $\mathrm{TI} / \mathrm{VI}$ & 29 & $95.5-103.0$ & $99.51 \pm$ & $2.39 \pm$ & $2.40 \pm$ \\
\hline TI/Cne & 30 & $187.4-210.5$ & $297.88 \mp$ & $5.36 \pm$ & $2.71 \pm$ \\
\hline $\mathrm{Ta} / \mathrm{Hu}$ & 37 & $61.0-76.6$ & $70.64 \ddagger$ & $2.75 \mp .32$ & $3.89 \pm$ \\
\hline $\mathrm{Ta} / \mathrm{UL}$ & 36 & $61.4-66.6$ & $64.444 \pm .33$ & $1.97 \mp .23$ & $3.06 \mp$ \\
\hline $\mathrm{Ta} / \mathrm{Cme}$ & 37 & $122.5-134.9$ & $128.37 \mp$ & $2.99 \mp .35$ & $2.33 \pm$ \\
\hline $\mathrm{Ha} / \mathrm{Hu}$ & 34 & $23.0-28.2$ & $25.12 \mp$ & $1.37 \pm .17$ & $5.45 \pm$ \\
\hline $\mathrm{Ha} / \mathrm{UI}$ & 34 & $21.7-25.6$ & $22.95 \mp .22$ & $1.28 \mp .16$ & $5.58 \mp .68$ \\
\hline $\mathrm{Ba} / \mathrm{Cnie}$ & 35 & $41.9-50.5$ & $45.76 \mp .29$ & $1.69 \mp .20$ & $3.69 \mp .44$ \\
\hline $\mathrm{Hh} /$ II & 35 & $88.8-92.8$ & $90.93 \mp$ & $1.10 \mp .13$ & $1.21 \mp .24$ \\
\hline $\mathrm{Ra} / \mathrm{UI}$ & 37 & $94.5-97.0$ & $95.63 \mp$ & $0.75 \mp .09$ & $0.78 \mp .09$ \\
\hline ane/ur & 36 & $47.9-54.0$ & $50.26 \pm .18$ & $1.07 \mp .13$ & $2.13 \pm$ \\
\hline$P-1 / U 2$ & 37 & $16.7-19.2$ & $17.85 \mp .09$ & $0.57 \mp .07$ & $3.19 \pm$ \\
\hline$P-2 / 01$ & 35 & $13.4-16.9$ & $15.52 \pm .14$ & $0.80 \mp .10$ & $5.25 \pm$ \\
\hline $\mathrm{Pe} / \mathrm{TL}$ & 30 & $57.7-62.3$ & $59.60 \mp$ & $1.16 \mp .15$ & $1.95 \pm$ \\
\hline $\mathrm{Ta} / \mathrm{T1}$ & 31 & $61.5-67.8$ & $64.98 \pm .45$ & $2.50 \pm .32$ & $3.85 \mp .49$ \\
\hline $\mathrm{Ha} / \mathrm{Tl}$ & 32 & $21.5-25.2$ & $23.12 \pm .17$ & $0.96 \pm .12$ & $4.25 \pm .52$ \\
\hline
\end{tabular}




\section{Tablo 2 (cont.) \\ Ratios (per cent)}

Hycticorer caledonicus

\begin{tabular}{|c|c|c|c|c|c|}
\hline Ratio & II & n & M & SD & $\nabla$ \\
\hline Pre/Sk & 1 & 12.5 & 32.50 & & \\
\hline Pre/Post & I & Wh. 8 & 44.80 & & \\
\hline Pre/cr & $i$ & 29.5 & 29.50 & & \\
\hline Post/Cr & 1 & 65.9 & $65^{\circ} .90$ & & \\
\hline $\mathrm{Pt} / \mathrm{Q1}$ & $i$ & 64.8 & 64.80 & & \\
\hline qw/en & $i$ & 79.3 & 79.30 & & \\
\hline $\begin{array}{l}\mathrm{Fe} / \mathrm{Hu} \\
\mathrm{Fe} / \mathrm{vg}\end{array}$ & 1 & 65.6 & 65.60 & & \\
\hline $\begin{array}{l}\mathrm{Fe} / \mathrm{sI} \\
\mathrm{Fe} / \mathrm{Cme}\end{array}$ & $\frac{1}{2}$ & $\begin{array}{r}59.4 \\
279.1\end{array}$ & $\begin{array}{r}59.40 \\
119.10\end{array}$ & & \\
\hline 21/thu & 2 & 113.6 & 113.60 & & \\
\hline $1 / 01$ & 1 & 102.9 & 102.90 & & \\
\hline $21 /$ ane & $i$ & 206.4 & 206.40 & & \\
\hline 2a/thu & 1 & 74.8 & 74.80 & & \\
\hline xa/u & $i$ & 67.8 & 67.80 & & \\
\hline Ta/one & 2 & 235.9 & 235.90 & & \\
\hline $\mathrm{He} / \mathrm{hl} \mathrm{ha}$ & 1 & 25.6 & 25.60 & & \\
\hline lee/or & 1 & 23.2 & 23.20 & & \\
\hline 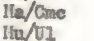 & $\frac{2}{2}$ & $\begin{array}{l}46.5 \\
90.6\end{array}$ & 46.50 & & \\
\hline $\begin{array}{l}\text { Ina/OI } \\
\text { Re/ / } 121\end{array}$ & $\frac{1}{2}$ & $\begin{array}{l}90.6 \\
95.5\end{array}$ & $\begin{array}{l}90.60 \\
95.50\end{array}$ & & \\
\hline $\mathrm{Cac} / \mathrm{UI}$ & 1 & 49.9 & 49.90 & & \\
\hline$P-1 / 01$ & 1 & 17.5 & 17.50 & & \\
\hline$-2 / 01$ & 1 & 15.2 & 15.20 & & \\
\hline $\mathrm{Ce} / \mathrm{r1}$ & 1 & 57.7 & 57.70 & & \\
\hline $\begin{array}{l}\mathrm{Fe} / \mathrm{TL} \\
\mathrm{Ha} / \mathrm{TI}\end{array}$ & 1 & 65.9 & 65.90 & & \\
\hline & & 22.5 & 22.50 & & \\
\hline
\end{tabular}


Table 2 (cont,)

Ratios (per cent)

livetanasea violecea violacee

\begin{tabular}{|c|c|c|c|c|c|}
\hline Ratio & II & $R$ & $\mu$ & $S D$ & $\nabla$ \\
\hline Pre/sk & 19 & $12.3-13.5$ & $12.87 \div .17$ & $0.72 \pm .12$ & $5.59 \div .91$ \\
\hline Pre/Post & 19 & $42.6-47.4$ & $44.99 \div .42$ & $1.84 \pm .30$ & $4.09 \div .66$ \\
\hline $\mathrm{Pxe} / \mathrm{Cr}^{\circ}$ & 19 & $28.1-32.0$ & $29.39 \div .27$ & $1.17 \pm$ & $3.98 \div$ \\
\hline Post/Cx & 19 & $61.1-69.1$ & $65.12 \pm .46$ & $2.99 \pm .32$ & $3.06 \div .50$ \\
\hline$P t / P 1$ & 18 & $55.8-65.4$ & $62.03 \pm .68$ & $2.89 \div .48$ & $4.66 \pm .78$ \\
\hline $0 \times / e_{2}$ & 18 & $76.9-88.5$ & $83.93 \pm .67$ & $2.86 \pm .48$ & $3.42 \pm .57$ \\
\hline $80 /$ thu & 19 & $58.9-62.1$ & $60.42 \div .15$ & $0.66 \pm .71$ & $1.09 \pm .28$ \\
\hline $\mathrm{Pe} / \mathrm{UL}^{2}$ & 28 & $49.9-53.5$ & $52.13 \pm .25$ & $1.05 \mp .18$ & $2.01 \div .34$ \\
\hline $\mathrm{re} / \mathrm{cme}$ & 18 & $105.9-112.7$ & $108.57 \pm .53$ & $2.24 \pm .37$ & $2.06 \pm .34$ \\
\hline $\mathrm{TI} / \mathrm{Iu}$ & 19 & $121.4-135.0$ & $126.42 \pm .88$ & $3.74 \mp .62$ & $2.96 \pm .49$ \\
\hline T/VI & 18 & $105.0-115.2$ & $108.89 \pm .56$ & $2.38 \pm .40$ & $2.19 \pm .37$ \\
\hline II/Gane & 18 & $217.9-239.1$ & $226.92 \pm 1.46$ & $6.18 \mp 1.03$ & $2.72 \mp .45$ \\
\hline $\mathrm{Ta} / \mathrm{llin}$ & 19 & $89.3-99.6$ & $92.64 \pm .55$ & $2.39 \pm .39$ & $2.58 \pm .42$ \\
\hline $\mathrm{Te} / \mathrm{Uz}$ & 18 & & $79.77 \pm .42$ & $1.80 \pm .30$ & $2.26 \pm .38$ \\
\hline $\mathrm{Te} / \mathrm{cme}$ & 18 & $159.6-176.9$ & $166.27 \pm .85$ & $3.62 \mp .60$ & $2.18 \pm .36$ \\
\hline $\mathrm{He} / \mathrm{hu}$ & 19 & $20.9-23.1$ & $22.19 \pm .15$ & $0.67 \pm .27$ & $3.02 \mp .49$ \\
\hline He/rol & 18 & $19.1-20.4$ & $19.20 \pm .23$ & $0.99 \pm .27$ & $5.16 \pm .86$ \\
\hline He/Ganc & 18 & $34.3-42.2$ & $39.66 \pm .42$ & $1.76 \mp .29$ & $4.44 \pm .74$ \\
\hline $102 / 02$ & 18 & $83.6-89.0$ & $86.31 \pm .33$ & $1.39 \pm .23$ & $1.62 \mp .27$ \\
\hline $\mathrm{Ha} / \mathrm{LI}$ & 18 & $94.3-96.3$ & $95.55 \pm .22$ & $0.94 \pm .16$ & $0.98 \mp .16$ \\
\hline $\mathrm{Cmc} / \mathrm{OL}$ & 17 & $46.5-49.0$ & $48.02 \pm .12$ & $0.51 \mp .09$ & $1.06 \pm .18$ \\
\hline$-1 / 01$ & 18 & $16.2-18.4$ & $27.26 \pm .17$ & $0.13 \pm .12$ & $4.23 \mp .71$ \\
\hline$-2 / 02$ & 18 & $12.9-15.9$ & $24.58 \pm .17$ & $0.73 \pm .22$ & $5.01 \pm$ \\
\hline$P / M$ & 19 & $44.2-49.7$ & $47.83 \pm .32$ & $1.37 \mp .22$ & $2.86 \pm$ \\
\hline $20 / \pi 1$ & 29 & $69.0-76.4$ & $73.30 \pm .45$ & $1.97 \pm .32$ & $2.69 \pm .44$ \\
\hline & 19 & $16.5-18.9$ & $17.62 \pm .15$ & $0.66 \pm .22$ & $3.75 \pm .61$ \\
\hline
\end{tabular}




\author{
Table 2 (cont,) \\ Ratilos (per cent)
}

Hretanassa yiolaces bencroft1

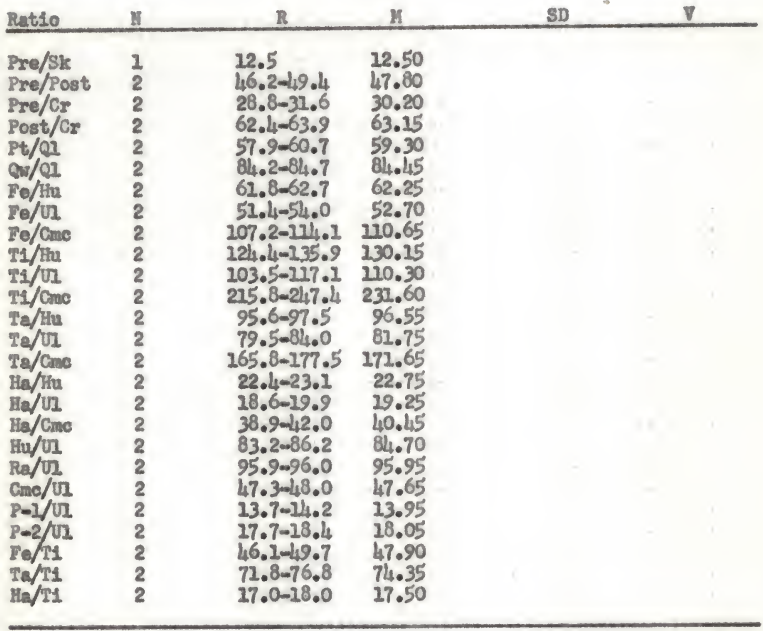




\author{
Table 2 (cont.) \\ Ratios (per cent)
}

Corsachtus nelenolophus

\begin{tabular}{|c|c|c|c|c|c|}
\hline Ratio & 표 & $R$ & $M$ & SD & $\nabla$ \\
\hline Pre/Sk & 1 & 13.3 & 23.30 & & \\
\hline Pre/Post & 1 & 43.1 & 43.10 & & \\
\hline Pre/Cr & 1 & 27.1 & 27.10 & & \\
\hline Post/Cr & 1 & 62.8 & 62.80 & & \\
\hline$P t / Q 1$ & 1 & 70.1 & 70.20 & & \\
\hline Qv/Q1 & 1 & 92.4 & 92.40 & & \\
\hline Fe/fhu & 1 & 60.8 & 60.80 & & \\
\hline $\mathrm{Fe} / \mathrm{UL}$ & 1 & 52.2 & 52.20 & & \\
\hline $\mathrm{Fe} / \mathrm{Cme}$ & 1 & 109.2 & 109.20 & & \\
\hline $\mathrm{TI} / \mathrm{Hu}$ & 1 & 107.4 & 207.40 & & \\
\hline $91 / \Omega$ & 1 & 92.1 & 92.10 & & \\
\hline TI/Canc & 1 & 292.8 & 192.80 & & \\
\hline Te/thu & 1 & 71.8 & 71.80 & & \\
\hline $\mathrm{Ta} / \mathrm{OI}$ & 1 & 61.6 & 61.60 & & \\
\hline $\mathrm{Ta} / \mathrm{Cnc}$ & 1 & 128.9 & 128.90 & & \\
\hline $\mathrm{HI} / \mathrm{hus}$ & 1 & 22.5 & 22.50 & & \\
\hline $\mathrm{Ha} / \mathrm{JI}$ & 1 & 29.3 & 19.30 & & \\
\hline $\mathrm{Ha} / \mathrm{Gnc}$ & 1 & 40.3 & 40.30 & & \\
\hline $\mathrm{Hu} / \mathrm{GI}$ & 1 & 85.8 & 85.30 & & \\
\hline $\mathrm{rad} / \mathrm{I}$ & 1 & 96.2 & 96.20 & & \\
\hline $\mathrm{Cme} / \mathrm{NI}$ & 1 & 47.8 & 47.80 & & \\
\hline $\begin{array}{l}P-1 / v 1 \\
P-2 / U 1\end{array}$ & 1 & 16.6 & 16.60 & & \\
\hline $50 / 21$ & 1 & $\begin{array}{l}13.3 \\
56.6\end{array}$ & $\begin{array}{l}13.30 \\
56.60\end{array}$ & & \\
\hline$T a / T 1$ & 1 & 66.9 & 66.90 & & \\
\hline $\mathrm{H} / \mathrm{TI}$ & 1 & 20.9 & 20.90 & & \\
\hline
\end{tabular}




\section{Table 2 (cont.) \\ Ratios (per cent)}

Tigriomis leucolophs

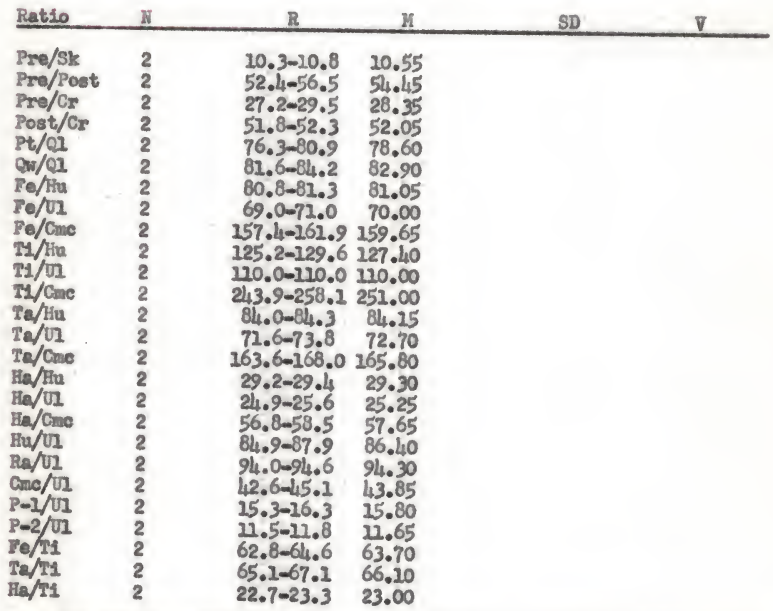


Table 2 (cont.)

Ratios (per cent)

Tigrisone Iineatum

\begin{tabular}{|c|c|c|c|c|c|}
\hline Ratio & $\mathbb{N}$ & $\mathrm{B}$ & $\mathrm{M}$ & $S D$ & $v$ \\
\hline $\mathrm{Pro} / \mathrm{Sk}$ & 4 & $9.0-10.5$ & $10.23 \pm .41$ & $0.82 \div .29$ & $8.02 \pm 2.83$ \\
\hline Pre/Post & 5 & $44.9-53.2$ & $48.98 \mp 1.56$ & $3.19 \mp \mp 1.10$ & $7.23 \mp 2.26$ \\
\hline $\mathrm{Pre} / \mathrm{Cr}$ & 5 & $25.0-28.8$ & $27.30 \pm .66$ & $3.47 \pm .47$ & $5.38 \pm 1.70$ \\
\hline Post/Cr & 5 & $53.1-57.9$ & $55.84 \mp .82$ & $1.84=.58$ & $3.30 \pm 1.04$ \\
\hline Pt/Q1 & 4 & $63.9-71.2$ & $68.18 \pm 1.77$ & $3.53 \div 1.25$ & $5.18+1.83$ \\
\hline $00 / 01$ & 5 & $81.9-92.8$ & $86.110+1.96$ & $1.39+1.39$ & $5.08+1.62$ \\
\hline $\mathrm{Fo} / \mathrm{liu}$ & 5 & $72.8-77.2$ & $75.10 \div .76$ & $2.70 \div .54$ & $2.26 \mp .72$ \\
\hline $\mathrm{Fe} / \mathrm{VI}_{1}$ & 4 & $61.4=-64.3$ & $63.05 \div .70$ & $1.39 \div .19$ & $2.20 \div .78$ \\
\hline $\mathrm{Fo} / \mathrm{Cme}$ & 5 & $233.7-114.9$ & $139.24+1.43$ & $3.21+1.02$ & $2.31 \mp .73$ \\
\hline $\mathrm{T1} / \mathrm{hu}$ & 4 & $124_{1} .0-131.0$ & $126.78 \pm 1.42$ & $2.83 \pm 2.00$ & $2.23 \pm .79$ \\
\hline TI/U1 & 3 & $106.4-108.7$ & $107.47^{-}$ & & \\
\hline T1/Gac & 4 & $230.3-2140.7$ & $234.05 \div 2.35$ & $4.69+1.66$ & $2.00 \pm .71$ \\
\hline $\mathrm{Ta} / \mathrm{Hu}$ & $\frac{4}{3}$ & $88.8-95.0$ & $91.23 \pm 1.32$ & $2.62 \pm .93$ & $2.87 \pm 1.02$ \\
\hline $\mathrm{Fa} / \mathrm{ane}$ & 4 & $264.9-174.5$ & $168.40+2.13$ & $4.25+1.50$ & $2.52+.89$ \\
\hline $\mathrm{Ha} / \mathrm{Hu}$ & 4 & $25.9-29.8$ & $27.85 \pm .83$ & $1.66 \pm .59$ & $5.96 \mp 2.11$ \\
\hline $\mathrm{Ha} / \mathrm{UI}$ & 3 & $21.5-21.0$ & $22.90^{-}$ & & \\
\hline $\mathrm{Hla} / \mathrm{Gme}$ & 4 & $47.6-55.3$ & $51.21_{4}+2.63$ & $3.26 \div 1.15$ & $6.34 \pm 2.24$ \\
\hline Hy/UI & 4 & $83.0-85.1$ & $84.18 \div .23$ & $0.45 \pm .16$ & $0.53 \mp .19$ \\
\hline $\mathrm{Ra} / \mathrm{I}$ & 4 & $93.80-95.1$ & $94.62 \mp .50$ & $1.00 \pm .35$ & $2.06 \pm .37$ \\
\hline Canc/ur & 4 & $44.7-45.9$ & $45.43 \mp .10$ & $0.20 \mp .07$ & $0.44 \mp .26$ \\
\hline$P=1 / \mathrm{N}$ & 3 & 25.10 .16 .3 & $25.50^{-}$ & & \\
\hline$[-2 / U I$ & 3 & 12.0 .12 .6 & 22.37 & & \\
\hline $\mathrm{Pe} / \mathrm{TI}$ & 4 & $57.7 \times 61.2$ & $59.45 \pm .74$ & $2.48 \pm .52$ & $2.49 \pm .88$ \\
\hline$=\alpha / T 1$ & 4 & $72.2-72.5$ & $72.95 \pm .33$ & $0.66 \mp .23$ & $0.92 \mp .33$ \\
\hline $\mathrm{Ha} / \mathrm{TI}$ & 4 & $29.8 \cdot .24 .0$ & $22.00 \mp .88$ & $2.75 \pm .62$ & $7.95 \mp 2.81$ \\
\hline
\end{tabular}


Table 2 (cont.)

Ratios (per cent)

Migrisome mexicene

\begin{tabular}{|c|c|c|c|c|c|}
\hline Rat1o & N & $\mathrm{B}$ & M & $S D$ & $\nabla$ \\
\hline Pre/Sk & 8 & $8.7-10.3$ & $9.45 \pm .20$ & $0.56 \pm . U_{4}$ & $5.93+1.48$ \\
\hline Pre/Post & $?$ & $44.5-49.7$ & $47.72 \pm .73$ & $1.95 \div .52$ & $4.09+1.09$ \\
\hline Pre/Cr & 8 & $23.4-26.8$ & $25.34 \pm .34$ & $0.96 \pm .24$ & $3.79 \pm .95$ \\
\hline Post/Cr & $?$ & $50.6-55.2$ & $52.84 \pm .64$ & $2.72 \mp .146$ & $3.24 \pm .07$ \\
\hline $\mathrm{Pt} / \mathrm{QI}$ & 8 & $67.0-75.3$ & $71.84 \pm 1.02$ & $2.89 \div .72$ & $4.02 \pm 1.01$ \\
\hline $\mathrm{m} / \mathrm{Q2}$ & 8 & $83.9-88.6$ & $87.09 \pm .55$ & $1.55 \pm .39$ & $1.78 \pm .45$ \\
\hline $\mathrm{Fe} / \mathrm{Hu}$ & 8 & $66.5-72.8$ & $70.46 \pm .87$ & $2.46 \pm .62$ & $3.49 \pm .87$ \\
\hline $\mathrm{Te} / \mathrm{uL}$ & 7 & $58.0-62.1$ & $59.24 \pm .58$ & $2.55 \pm .41$ & $2.62 \pm .70$ \\
\hline so/Cme & 7 & $128.9-135.1$ & $131.54 \pm 3.28$ & $8.49 \pm 2.27$ & $6.45 \pm 1.72$ \\
\hline T1/liu & 7 & $121.4-230.0$ & $126.63 \pm 1.07$ & $2.85 \pm .76$ & $2.25 \mp .60$ \\
\hline$T 1 / 01$ & ? & $102.7-108.6$ & $105.44 \pm .89$ & $2.37 \mp .63$ & $2.25 \mp .60$ \\
\hline $\mathrm{TI} / \mathrm{Gme}$ & 7 & $229.1-238.2$ & $234.53 \pm 1.17$ & $3.13 \pm .84$ & $2.33 \mp$ \\
\hline $\mathrm{Te} / \mathrm{Hu}$ & 8 & $87.0-91.8$ & $87.84 \pm .98$ & $2.78 \pm .70$ & $3.16 \pm .79$ \\
\hline Ta/uI & 8 & $72.2-75.2$ & $73.91 \div .37$ & $1.06 \pm .27$ & $1.43 \div .36$ \\
\hline Te/Gne & 8 & $159.9-166.6$ & $163.89 \pm .72$ & $2.03 \mp .51$ & $1.24 \pm .32$ \\
\hline $\mathrm{He} / \mathrm{lih}$ & 8 & $26.2-30.0$ & $28.26 \pm .45$ & $1.28 \pm .32$ & $4.55 \mp 1.1_{4}$ \\
\hline Ha/un & 8 & $22.9-25.1$ & $23.73 \pm .25$ & $0.72 \pm .28$ & $3.03 \pm .76$ \\
\hline $\mathrm{He} / \mathrm{Cane}$ & 8 & $50.9-55.0$ & $52.57 \pm .19$ & $0.54 \pm$ & $1.03 \mp .26$ \\
\hline Hin/or. & 8 & $81.0-90.7$ & $84.20 \$ 1.07$ & $3.02 \pm .76$ & $3.59 \mp$ \\
\hline Re/ us & 8 & $93.8-96.9$ & $95.05 \pm .35$ & $0.98 \mp .25$ & $1.03 \pm .26$ \\
\hline $\mathrm{Gnc} /$ in & 8 & $44.3-46.0$ & $45.09 \pm .21$ & $0.59 \pm .15$ & $1.37 \pm .33$ \\
\hline$P-1 / V I$ & 8 & $u_{4} .7-26.4$ & $15.66 \pm .21$ & $0.59 \mp .15$ & $3.77 \pm .94$ \\
\hline$P-2 / V^{2}$ & 8 & $12.9-24.1$ & $13.46 \pm .28$ & $0.52 \pm .13$ & $3.66 \pm .97$ \\
\hline $\mathrm{Fe} / \mathrm{Tg}$ & 6 & $55.1-57.2$ & $56.27 \pm .33$ & $0.80 \mp .23$ & $1.42 \pm$ \\
\hline $\begin{array}{l}\mathrm{Te} / \mathrm{TI} \\
\mathrm{H} / \mathrm{TI}\end{array}$ & $?$ & $67.8-72.0$ & $70.00 \pm .55$ & $2.46 \pm .39$ & $2.09 \pm .56$ \\
\hline $\mathrm{H} / \mathrm{a} / \mathrm{TL}$ & 7 & $21.6-23.9$ & $22.147 \pm .32$ & $0.85 \mp .23$ & $3.78 \pm 1.02$ \\
\hline
\end{tabular}


Table 2 (cont.)

Rat1os (per cent)

Irobrychus sinensis

\begin{tabular}{|c|c|c|c|c|c|}
\hline Ratio & II & $\mathbb{R}$ & $M$ & SD & $\nabla$ \\
\hline Fre/sk & 1 & 20.3 & 20.30 & & \\
\hline Pre/Post & 1 & 57.6 & 57.60 & & \\
\hline Pre/Cr & $\overline{1}$ & 27.0 & 27.00 & & \\
\hline Post/Cr & 1 & & 46.80 & & \\
\hline $\mathrm{Pt} / \mathrm{QI}$ & $\bar{I}$ & 68.0 & 68.10 & & \\
\hline$Q w / Q 1$ & 2 & 81.3 & 81.30 & & \\
\hline re/tiu & 1 & 85.3 & 85.30 & & \\
\hline $\mathrm{Po} / \mathrm{v1}$ & 0 & & & & \\
\hline Po/Gne & 1 & 163.5 & 163.50 & & \\
\hline $\mathrm{TI} / \mathrm{hu}$ & 1 & 131.2 & 131.20 & & \\
\hline T1/02 & 0 & & & & \\
\hline T1/Cunc & 1 & 251.3 & 251.30 & & \\
\hline Tartu & 1 & 87.3 & 87.30 & & \\
\hline $98 / 01$ & 0 & & & & \\
\hline Ta/Canc & 1 & 167.3 & 167.30 & & \\
\hline $\mathrm{Ha} / \mathrm{Hu}$ & 1 & 35.5 & 35.50 & & \\
\hline H/VI & 0 & & & & \\
\hline $\mathrm{Hid} / \operatorname{Cane}$ & 1 & 68.1 & 68.10 & & \\
\hline $\mathrm{kn} / \mathrm{/2}$ & 0 & & & & \\
\hline$R \mathscr{R} / \mathrm{I}$ & 0 & & & & \\
\hline $\mathrm{Canc} / \mathrm{UL}^{2}$ & 0 & & & & \\
\hline$P-1 / 01$ & 0 & & & & \\
\hline$P-2 / 01$ & 0 & & & & \\
\hline $\mathrm{F} / \mathrm{TI}$ & 1 & 65.1 & 65.10 & & \\
\hline $\mathrm{T} 2 / \mathrm{mL}$ & 1 & 66.6 & 66.60 & & \\
\hline $\mathrm{Hed} / 21$ & 1 & 27.1 & 27.10 & & \\
\hline
\end{tabular}


Table 2 (cont.)

Ratios (per cent)

Isobsrychus involucris

\begin{tabular}{|c|c|c|c|c|c|}
\hline Ratio & N & $\mathrm{R}$ & $\mathrm{M}$ & SD & $\nabla$ \\
\hline Pre/sk & 2 & 20.0 & 10.00 & & \\
\hline Pro/Post & $\bar{I}$ & 53.2 & 53.20 & & \\
\hline Pro/cr & 2 & 26.4 & 26.40 & & \\
\hline Post/Cr & 1 & 49.7 & 49.70 & & \\
\hline Pt/al & $\overline{1}$ & 84.6 & 84.60 & & \\
\hline Qw/O2 & 1 & 80.2 & 80.20 & & \\
\hline Po/hu & 1 & 90.0 & 90.90 & & \\
\hline $80 / \mathrm{UI}$ & 1 & 87.0 & 87.00 & & \\
\hline $\mathrm{Fe} / \mathrm{Gme}$ & $\overline{2}$ & 275.4 & 275.40 & & \\
\hline $\mathrm{TI} / \mathrm{Hu}$ & $i$ & 253.0 & 153.00 & & \\
\hline $21 / 01$ & 1 & 233.1 & 133.20 & & \\
\hline $\mathrm{TI} / \mathrm{Cme}$ & 1 & 268.4 & 268.40 & & \\
\hline Salliu & 1 & 87.0 & 87.00 & & \\
\hline $\mathrm{Ta} / \mathrm{s}$ & $i$ & 83.3 & 83.30 & & \\
\hline $\mathrm{Te} / \mathrm{ane}$ & $\overline{1}$ & 268.0 & 168.00 & & \\
\hline $\mathrm{Ha} / \mathrm{hu}$ & 2 & 35.8 & 35.80 & & \\
\hline $\mathrm{Ha} / \mathrm{JI}$ & 1 & 34.3 & 34.30 & & \\
\hline $\mathrm{Ha} / \mathrm{Canc}$ & 2 & 69.1 & 69.10 & & \\
\hline $\mathrm{Hu} / \mathrm{JI}$ & 1 & 95.7 & 95.70 & & \\
\hline $\mathrm{Ra} / \mathrm{OI}$ & 1 & 95.9 & 95.90 & & \\
\hline $\begin{array}{l}\mathrm{Cmc} / \mathrm{JI} \\
\mathrm{P}-1 / \mathrm{l}\end{array}$ & 1 & 49.6 & 49.60 & & \\
\hline$P=-1 / V_{1}$ & $\frac{1}{2}$ & $\begin{array}{l}10.0 \\
16.1\end{array}$ & $\begin{array}{l}18.00 \\
16.10\end{array}$ & & \\
\hline $\mathrm{Re} / \mathrm{TL}$ & 1 & 65.4 & 65.40 & & \\
\hline $\mathrm{Ta} / \mathrm{TI}$ & 1 & 62.6 & 62.60 & & \\
\hline $\mathrm{H} \otimes / \mathrm{TL}$ & $i$ & 25.8 & 25.80 & & \\
\hline
\end{tabular}


Table 2 (cont.)

Ratios (per cent)

Ixobrychus exilis

\begin{tabular}{|c|c|c|c|c|c|}
\hline Ratio & $\pi$ & $\mathrm{R}$ & $\pi$ & $S D$ & $v$ \\
\hline Pre/St & 9 & $20.3-11.3$ & $10.74 \pm .14$ & $0.41 \pm .10$ & $3.82 \pm .90$ \\
\hline Pre/Port & 10 & $52.3-56.3$ & $54.35 \mp .45$ & $1.41 \mp .32$ & $2.59 \pm .58$ \\
\hline Pre/Cr & 10 & $25.5-28.3$ & $26.73 \pm .29$ & $0.88 \pm .20$ & $3.29 \pm .74$ \\
\hline Post/Cr & 30 & $47.6-50.3$ & $49.28 \div .32$ & $1.01 \mp .23$ & $2.05 \mp .46$ \\
\hline $\mathrm{Pt} / \mathrm{Ol}$ & 9 & $65.6-75.4$ & $69.86 \pm .75$ & $2.28 \mp .54$ & $3.26 \mp .77$ \\
\hline $2 m / 01$ & 10 & $77.2-83.8$ & $80.53 \div .71$ & $2.25 \mp .71$ & $2.25 \div .62$ \\
\hline $\mathrm{Pe} / \mathrm{Hu}$ & 11 & $87.2-90.6$ & $88.98 \div .35$ & $1.25 \pm .25$ & $1.29 \mp$ \\
\hline Fe/v1 & 10 & $84.0=90.0$ & $86.61 \mp .55$ & $1.75 \mp .39$ & $2.02 \pm .45$ \\
\hline $\mathrm{Se} /$ Cme & 10 & $161.3-174.0$ & $170.49 \pm 1.20$ & $3.78 \pm .85$ & $2.22 \mp .50$ \\
\hline $\mathrm{TI} / \mathrm{Hu}$ & 10 & $135.6-111.0$ & $136.30 \mp .54$ & $2.72 \mp .38$ & $1.24 \mp .28$ \\
\hline $\mathrm{I} / \mathrm{UI}$ & 10 & $131.8-238.0$ & $134.35 \div .68$ & $2.16 \div .48$ & $1.61 \mp .36$ \\
\hline $\mathrm{TI} / \mathrm{Gme}$ & 9 & $254.4-275.1$ & $265.53+2.13$ & $6.38 \mp 1.50$ & $2.40 \mp .57$ \\
\hline Ta/thu & 9 & $86.6=39.5$ & $88.18 \div .31$ & $0.93 \mp .22$ & $2.05 \mp .25$ \\
\hline $\mathrm{Ta} / \mathrm{U}$ & 9 & $83.0-87.9$ & $85.63 \pm .52$ & $1.55 \div .37$ & $2.81 \pm .143$ \\
\hline $\mathrm{Te} /$ Onac & 8 & $167.1-175.1$ & $170.66 \mp .94$ & $2.66 \mp .67$ & $1.56 \mp .39$ \\
\hline $\mathrm{He} / \mathrm{Hiu}$ & 10 & $35.0-38.7$ & $36.68 \pm .36$ & $1.12 \pm .25$ & $3.05 \pm .68$ \\
\hline He/UI & 10 & $34.3-37.5$ & $35.69 \pm .34$ & $2.06 \pm .24$ & $2.97 \div .66$ \\
\hline $\mathrm{Ha} / \mathrm{Cme}$ & 10 & $67.7-74.5$ & $70.32 \mp .61$ & $1.92 \mp .43$ & $2.73 \pm .61$ \\
\hline $\mathrm{Hw} / \mathrm{UL}$ & 11 & $95.2-99.4$ & $97.15 \pm .42$ & $1.43 \div .30$ & $1.45 \pm .32$ \\
\hline Ra/UI & 10 & $94.0-95.4$ & $94.66 \pm .15$ & $0.48 \pm .12$ & $0.51 \pm .11$ \\
\hline $\mathrm{Cnc} / \mathrm{U}$ & 10 & $49.5-52.5$ & $50.76 \mp .30$ & $0.96 \pm .21$ & $1.89 \mp .42$ \\
\hline $\mathrm{P}-1 / \mathrm{I} \Omega$ & 10 & $16.3-17.7$ & $17.13 \mp .12$ & $0.39 \mp .09$ & $2.28 \mp .51$ \\
\hline $\mathrm{P}-2 / \mathrm{UI}$ & 10 & $23.8-16.1$ & $15.51 \pm .25$ & $0.79 \mp .18$ & $5.09 \pm 1.24_{4}$ \\
\hline $\mathrm{Fe} / \mathrm{Ti}$ & 10 & $62.4=66.2$ & $64.36 \pm .37$ & $1.27 \pm .26$ & $1.82 \pm .42$ \\
\hline $\mathrm{Ta} / \mathrm{T}$ & 8 & $62.0-65.4$ & $63.88 \mp .39$ & $3.09 \mp .27$ & $2.71 \mp .43$ \\
\hline $\mathrm{He} / 21$ & 9 & $25.1-28.4$ & $26.66 \pm .33$ & $0.98 \mp .23$ & $3.68 \mp .87$ \\
\hline
\end{tabular}




\section{Table 2 (cont.) \\ Rat1os (per cent) \\ Irobrychus einnemomeus}

\begin{tabular}{|c|c|c|c|c|c|}
\hline Rat10 & 11 & a & $\mu$ & SD & $v$ \\
\hline Pre/Sk & 1 & 13.5 & 23.50 & & \\
\hline Pre/Post & 1 & 60.3 & 60.30 & & \\
\hline $\mathrm{Pre} / \mathrm{Cr}$ & 1 & 32.3 & 32.30 & & \\
\hline Post/Cr & 1 & 53.5 & 53.50 & & \\
\hline $\begin{array}{l}P t / Q 1 \\
Q w / Q 1\end{array}$ & $\frac{2}{2}$ & $\begin{array}{l}60.8 \\
75.8\end{array}$ & $\begin{array}{l}60.80 \\
75.80\end{array}$ & & \\
\hline $\mathrm{Fo} / \mathrm{Hu}$ & 1 & $\begin{array}{l}75.8 \\
83.0\end{array}$ & $\begin{array}{l}75.80 \\
83.00\end{array}$ & & \\
\hline $\mathrm{Fe} / \mathrm{UI}$ & 1 & 76.9 & 76.90 & & \\
\hline $\mathrm{Fo} / \mathrm{Cme}$ & 1 & 214.6 & $1 / 4.60$ & & \\
\hline $\mathrm{T1} / \mathrm{Hu}$ & 2 & 130.2 & 130.20 & & \\
\hline TI/UI & 1 & 120.7 & 120.70 & & \\
\hline $\mathrm{T1} / \mathrm{anc}$ & 1 & 227.0 & 227.00 & & \\
\hline Ta/lhu & 1 & 82.3 & 82.30 & & \\
\hline $\mathrm{Te} / \mathrm{UI}$ & 1 & 76.3 & 76.30 & & \\
\hline Ta/Ches & 1 & 2.3 .4 & 143.140 & & \\
\hline Ha/liu & 2 & 34.0 & 34.00 & & \\
\hline $\mathrm{Ha} / \mathrm{J}$ & 1 & 32.5 & 31.50 & & \\
\hline Ha/Chac & 1 & 59.3 & 59.30 & & \\
\hline Ho/ or & 2 & 92.7 & 92.70 & & \\
\hline $\mathrm{Re} / \mathrm{NI}$ & 2 & 92.5 & 92.50 & & \\
\hline Gine/on & 2 & 53.2 & 53.20 & & \\
\hline$P-1 / / 1$ & 1 & 27.5 & 27.50 & & \\
\hline $\begin{array}{l}\mathrm{P}-2 / \mathrm{VI} \\
\mathrm{P} \cdot \mathrm{TI}\end{array}$ & 1 & 25.6 & 25.60 & & \\
\hline $\mathrm{T} / \mathrm{T} / \mathrm{T2}$ & $\begin{array}{l}1 \\
1\end{array}$ & $\begin{array}{l}63.7 \\
63.2\end{array}$ & $\begin{array}{l}63.70 \\
63.20\end{array}$ & & \\
\hline $\mathrm{He} / \mathrm{T1}$ & $\overline{1}$ & 26.1 & 26.10 & & \\
\hline
\end{tabular}




\section{Table 2 (cont.) \\ Ratios (per cent)}

Irobrychus strumss

\begin{tabular}{|c|c|c|c|c|c|}
\hline Rat10 & $\mathbb{I}$ & 具 & If & $S D$ & $\nabla$ \\
\hline Pre/Sk & 2 & 22.8 & 22.80 & & \\
\hline Pre/Post & 1 & 49.7 & 49.70 & & \\
\hline Pre/Cr & 1 & 27.4 & 27.40 & & \\
\hline Post/Cr & 1 & 55.2 & 55.10 & & \\
\hline $\mathrm{Qw} / \mathrm{Q} 2$ & 1 & 90.9 & 90.90 & & \\
\hline $\mathrm{Pe} / \mathrm{lin}$ & $\vec{i}$ & 72.7 & 72.70 & & \\
\hline $\mathrm{re} / \mathrm{vr}$ & 1 & 67.4 & 67.40 & & \\
\hline $\mathrm{Fe} / \mathrm{Cme}$ & 2 & 129.2 & 129.20 & & \\
\hline $\mathrm{T1} / \mathrm{Hu}$ & $i$ & 239.8 & 111.80 & & \\
\hline $\mathrm{TI} / \mathrm{U}$ & 1 & 104.6 & 104.60 & & \\
\hline $\mathrm{II} / \mathrm{Cme}$ & I & 198.6 & 298.60 & & \\
\hline $\mathrm{Ta} / \mathrm{Hu}$ & $i$ & 69.7 & 69.70 & & \\
\hline $\mathrm{Ia} / \mathrm{Cme}$ & 1 & 123.8 & 123.80 & & \\
\hline $\mathrm{Ha} / \mathrm{Hu}$ & 1 & 30.5 & 30.50 & & \\
\hline $\mathrm{Ha} / \mathrm{OL}$ & 2 & 28.2 & 28.20 & & \\
\hline $\mathrm{Hl} / \mathrm{Gno}$ & 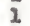 & 54.2 & 54.10 & & \\
\hline $\mathrm{Ha} / \mathrm{UL}$ & $\vec{i}$ & 92.6 & 92.60 & & \\
\hline Ra/g & 2 & 95.1 & 95.10 & & \\
\hline Che/U1 & 1 & 52.2 & 52.10 & & \\
\hline$P-1 / 01$ & $i$ & 17.9 & 17.90 & & \\
\hline$P-2 / 01$ & 1 & 15.4 & 16.40 & & \\
\hline Io/ 11 & 1 & 65.2 & 65.10 & & \\
\hline $\mathrm{Ta} / \mathrm{TL}$ & 1 & 62.3 & 62.30 & & \\
\hline $\mathrm{H} 2 / \mathrm{TL}$ & 1 & 27.6 & 27.60 & & \\
\hline
\end{tabular}


Iable 2 (cont.)

Ratios (per cent)

Botaurus atellaris

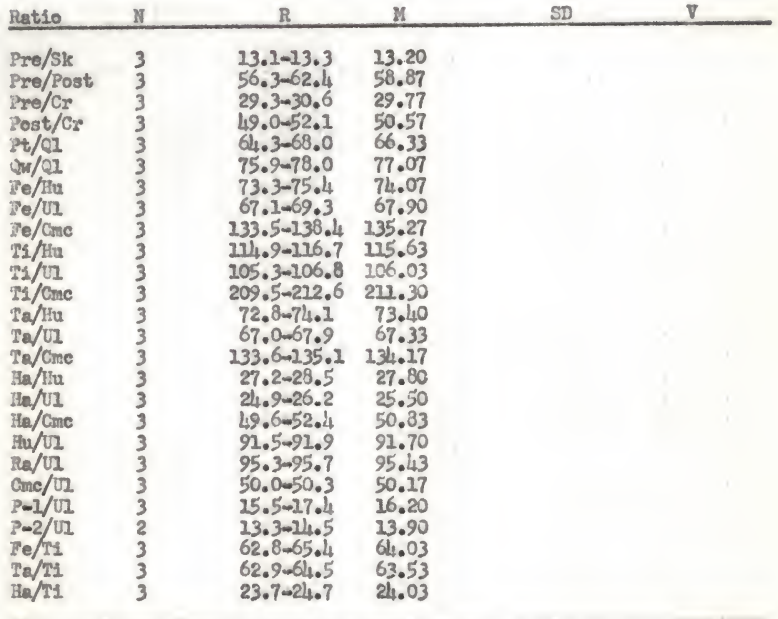


Table 2 (cont.)

Ratios (per cent)

Botaurus Ientiginosus

\begin{tabular}{|c|c|c|c|c|c|}
\hline Ratio & N & $\mathbf{R}$ & $y$ & SD & $\nabla$ \\
\hline Pre/Sk & 15 & $11.0-13.3$ & $12.14 \pm .16$ & $0.60 \pm .12$ & $4.94 \pm .90$ \\
\hline Pre/Post & 话 & $54.5-62.9$ & $58.33 \pm .84$ & $3.15 \div .60$ & $5.40+1.02$ \\
\hline $\mathrm{Pre} / \mathrm{Cr}$ & 15 & $25.9-32.8$ & $29.33 \pm .76$ & $2.95 \pm .54$ & $20.06+1.816$ \\
\hline Post/Cr & 18 & $47.4-54.9$ & $50.45 \mp .48$ & $2.04 \mp .34$ & $4.04 \div .67$ \\
\hline $\mathrm{Pt} / \mathrm{QI}$ & 19 & $59.2-69.6$ & $63.96 \pm .74$ & $3.22 \pm .52$ & $5.03 \div$ \\
\hline $9 \pi / 01$ & 19 & $72.2-81.6$ & $79.59 \pm .75$ & $3.25 \div .53$ & $4.08 \div$ \\
\hline $\mathrm{Fe} / \mathrm{Bu}$ & 17 & $71.3-75.4$ & $73.13 \pm .35$ & $1.45 \div .25$ & $2.98 \div .34$ \\
\hline $\mathrm{Fe} / \mathrm{UI}$ & 16 & $64.5-69.7$ & $66.86 \mp .47$ & $1.86 \pm .33$ & $2.81 \div .50$ \\
\hline $\mathrm{Fe} /$ Cne & 17 & $121.0-133.4$ & $127.40 \div .73$ & $2.99 \pm .51$ & $2.35 \div$ \\
\hline $\mathrm{N} / \mathrm{Hu}$ & 27 & $2 u_{4} \cdot 3-122.5$ & $218.27 \mp .44$ & $2.80 \mp .32$ & $1.52 \div$ \\
\hline $21 / 01$ & 17 & $205.1-122.7$ & $208.37 \mp .54$ & $2.23 \mp .38$ & $2.06 \div .35$ \\
\hline $21 / \operatorname{mec}$ & 18 & $295.6-225.9$ & $205.89+1.31$ & $5.55 \pm .93$ & $2.70 \div .45$ \\
\hline 2a/hu & 17 & $75.2-86.4$ & $80.78 \pm .71$ & $2.94 \mp .50$ & $3.64 \div .62$ \\
\hline Ta/us & 37 & $69.9-79.1$ & $74.15 \div .50$ & $2.07 \div .36$ & $2.79 \div .48$ \\
\hline Ta/Cane & 18 & $133.2-151.4$ & $\nu_{10.90 \pm 1.32}$ & $5.58 \div .93$ & $3.96 \div .66$ \\
\hline $\mathrm{Ha} / \mathrm{Hu}$ & 18 & $30.3-34.1$ & $32.03 \pm .22$ & $0.91 \pm .15$ & $2.84 \mp .47$ \\
\hline $\mathrm{Ho} / \mathrm{Uz}$ & 18 & -31.5 & $29.144 \pm .32$ & $1.31 \mp .22$ & $4.45 \mp .74$ \\
\hline $\mathrm{Ha} / \mathrm{Cne}$ & 19 & $53.2-59 \cdot 2$ & $55.98 \pm .45$ & $1.95 \mp .32$ & $3.48 \div .56$ \\
\hline $\mathrm{Hu} / \mathrm{UL}$ & 17 & $89.8-93.7$ & $91.56 \pm .33$ & $1.35 \mp .23$ & $1.47 \mp .25$ \\
\hline $\mathrm{Ro} / \mathrm{uI}$ & 18 & $94.2-96.1$ & $95.06 \pm .23$ & $1.00 \pm .17$ & $1.05 \div .18$ \\
\hline $\mathrm{Cme} / \mathrm{LI}$ & 18 & $51.3-53.2$ & $52.46 \pm .13$ & $0.57 \mp .10$ & $1.09 \mp .18$ \\
\hline$P-1 / 01$ & 18 & $15.1-19.1$ & $17.32 \mp .28$ & $0.77 \mp .13$ & $4.45 \pm .74$ \\
\hline$P-2 / 01$ & 15 & $12.4-15.2$ & $14.13 \pm .18$ & $0.69 \mp .13$ & $4.89 \mp .89$ \\
\hline $\mathrm{Pe} / \mathrm{TI}$ & 16 & $59.6-64.2$ & $61.95 \mp .33$ & $1.33 \mp .23$ & $2.25 \div .38$ \\
\hline & 17 & $66.6-71 \cdot 3$ & $68.72 \pm .38$ & $1.58 \mp .27$ & $2.30 \mp .39$ \\
\hline & & $25.8-29.5$ & $27.24 \pm .27$ & $1.14 \pm .19$ & $4.19 \mp .70$ \\
\hline
\end{tabular}


Table 2 (cont.)

Ratios (per cent)

Cochloarius cochlearius

\begin{tabular}{|c|c|c|c|c|c|}
\hline Rat1o & IN & $\mathrm{B}$ & M & SD & $\nabla$ \\
\hline Pre/Sk & 2 & $15.8-17.7$ & 16.75 & & \\
\hline Pre/Post & 2 & $50.7-58.4$ & 54.55 & & \\
\hline Pre/Cr & 2 & $35.2-41.0$ & 38.10 & & \\
\hline Post/Cr & 2 & $69.4-70.3$ & 69.85 & & \\
\hline Pt/Q1 & 2 & $63.9-68.9$ & 66.40 & & \\
\hline $0 w / 02$ & 2 & $93.8-95.8$ & 94.80 & & \\
\hline $\mathrm{Fo} / \mathrm{tha}$ & 2 & $69.7-79.3$ & 74.50 & & \\
\hline ro/UI & 2 & $59.5-62.4$ & 60.95 & & \\
\hline $\mathrm{Fe} / \mathrm{Gne}$ & 2 & $135.1-136.9$ & 236.00 & & \\
\hline T1/Ho & 2 & $119.9-129.5$ & 121.70 & & \\
\hline $21 / 01$ & 2 & $205.8-120.6$ & 108.20 & & \\
\hline $\mathrm{TI} / \mathrm{Cme}$ & 2 & $232.1-251.0$ & 211.55 & & \\
\hline To/liu & 2 & $78.0-86.9$ & 82.45 & & \\
\hline $\mathrm{Ta} / \mathrm{VI}$ & 2 & $68.9-74.3$ & 72.60 & & \\
\hline $\mathrm{Ta} / \mathrm{Cm}_{\mathrm{m}}$ & 2 & $151.0-168.6$ & 259.80 & & \\
\hline $\mathrm{He} / \mathrm{Hu}$ & $i$ & & 26.95 & & \\
\hline $\mathrm{Ha} / \mathrm{NI}$ & 1 & & 23.02 & & \\
\hline $\mathrm{He} / \mathrm{Cne}$ & 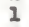 & & 52.24 & & \\
\hline $\mathrm{Hu} / \mathrm{u}$ & 2 & $85.4-38.2$ & 86.00 & & \\
\hline $\mathrm{Ra} / \mathrm{vI}$ & 2 & $94.3-94.9$ & 94.60 & & \\
\hline $\mathrm{Gme} / \mathrm{UI}$ & 2 & $44.1-45.6$ & b. 485 & & \\
\hline $\mathrm{P}-1 / \mathrm{G}$ & 2 & $17.1-17.5$ & 27.30 & & \\
\hline$P-2 / 01$ & 2 & $13.9-15.5$ & $U_{4.70}$ & & \\
\hline $\mathrm{re} / \mathrm{IL}$ & 2 & $53.8=59.0$ & 56.40 & & \\
\hline $\mathrm{Te} / \mathrm{T1}$ & 2 & $65.1-67.2$ & 66.25 & & \\
\hline $\mathrm{Ha} / \mathrm{T1}$ & 1 & & 20.82 & & \\
\hline
\end{tabular}


Fxplanation of Plate 1

Qualitative Osteological Characters

1. Internasal Septum

A. Absent

I. Intermediate

P. Present

2. Supraorbitel Vaculties

0. No vacusties

2. Troo vaculties

4. Four vaculties

3. Ectethmoid

B. Bridged

S. Separate

4. Lacrimal

P. Parallel

E. Angulate, entire

N. Angulate, notched

5. Inferior Hypocieidial Process

T. Truncate

N. Notched

A. Absent

6. Articular Surface of Caring

F. Broad, flat

P. Shiarply pointed

7. Intranuscular ifne of Coracoid

M. Mediar

I. Iateral

8. Tendinal Groove of Carponetacarpus

I. Enlarged

R. Reduced

9. Tibla-fibula

A. Ankylosed

Ni. Not ankglosed

10. Hypotarsus

1. One canal

2. Two canals

3. Three canals

11. Superior Hifpocleidial Process

S. Spatuiate

P. Pointed

A. Absent

12. Sternal Facet of Coracoid

L. Lateral

M. Medial 


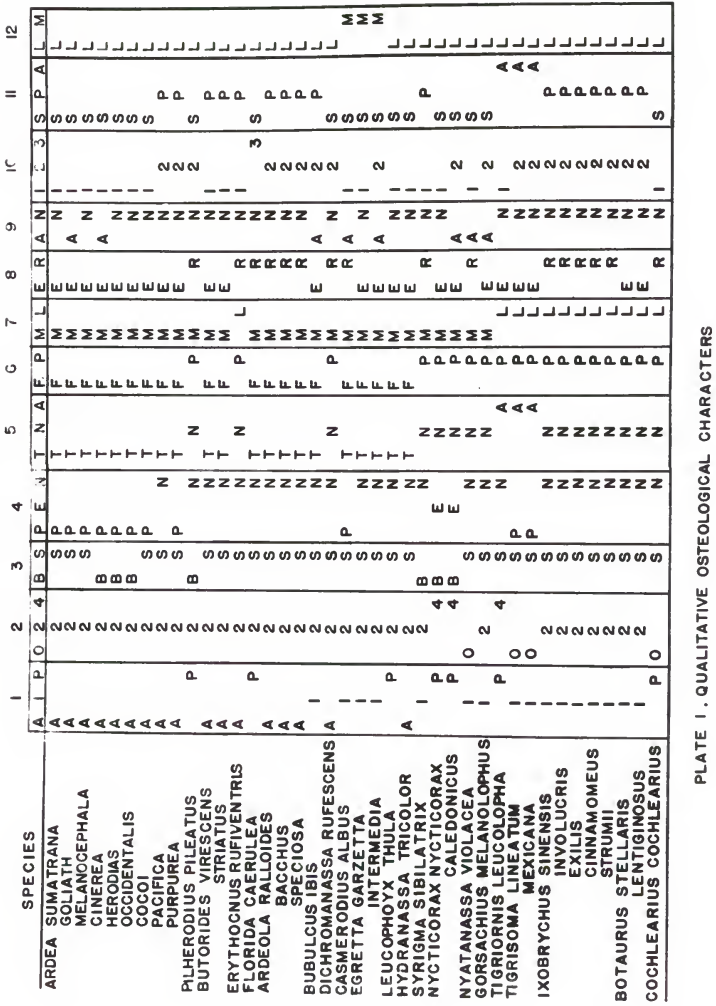


Explanation of Plate 2 Ratios

1. Ardea sumatrana

2. Ardea Boliath

3. Irdea melanocephala

4. Ardea cinerea

5. Ardea herodies

6. Ardea occidentalls

7. Ardea cocol

8. Ardea pacifice

9. Mrdea purrourea

10. pilherodias pileatus

11. Butorides virescons

12. Butorides striatus

13. Esythocmus rufiventria

14. Florida caerviea

15. Ardeola ralloldes

16. Ardeola bacchus

17. Andeola speciose

18. Bubulcus Ibis

19. Dichromanassa rufescens

20. Casmerodius albus

21. Egretta karzette

22. Egretta Intermiedia

23. Leucophovx thula

24. Ifydranassa tricolor

25. Syriema sibilatrix

26. Nycticorax nycticorrx

27. ifreticorax caledontcus

28. Nvetanassa violaces

29. Corsachius melanolophus

30. Tigriomis Ieucolophs

31. Tisrisoma Inestum

32. Tierisoma mexdcans

33. Irobrychus sinensis

34. Ixobrychus involucris

35. Ixobrychus exilis

36. Ixpbrychus cinnanomeus

37. Irobrychus strunil

38. Botaurus stellaris

39. Botaurus Ientiginosus

40. Cochlearius cochlearius 


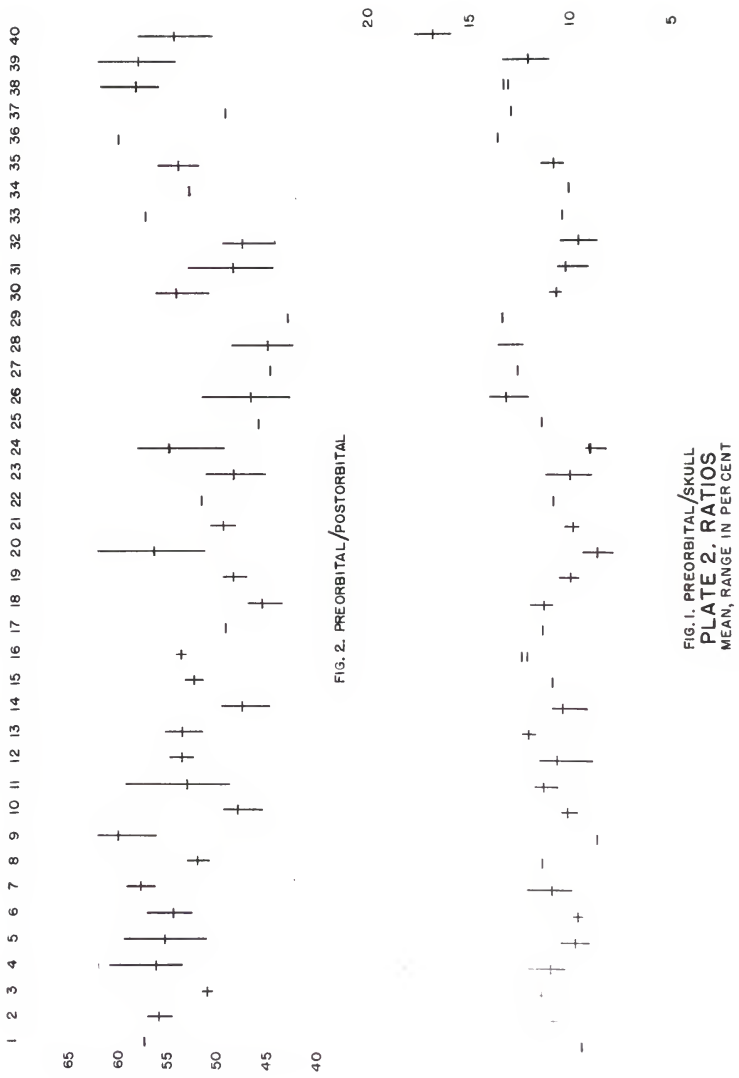


i

吕

品

吕

些

m
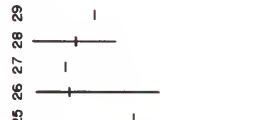

ฉ

ส

ส

ำ

음

음

工

는

ำ

$\pm$

m



$=$

으

$\sigma$

$\infty$

N

$\bullet$

()

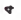

$m$

N

- 8 ะ

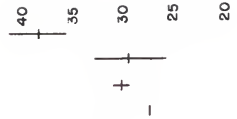

I
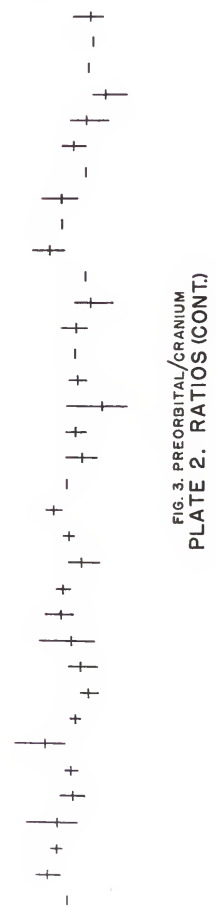

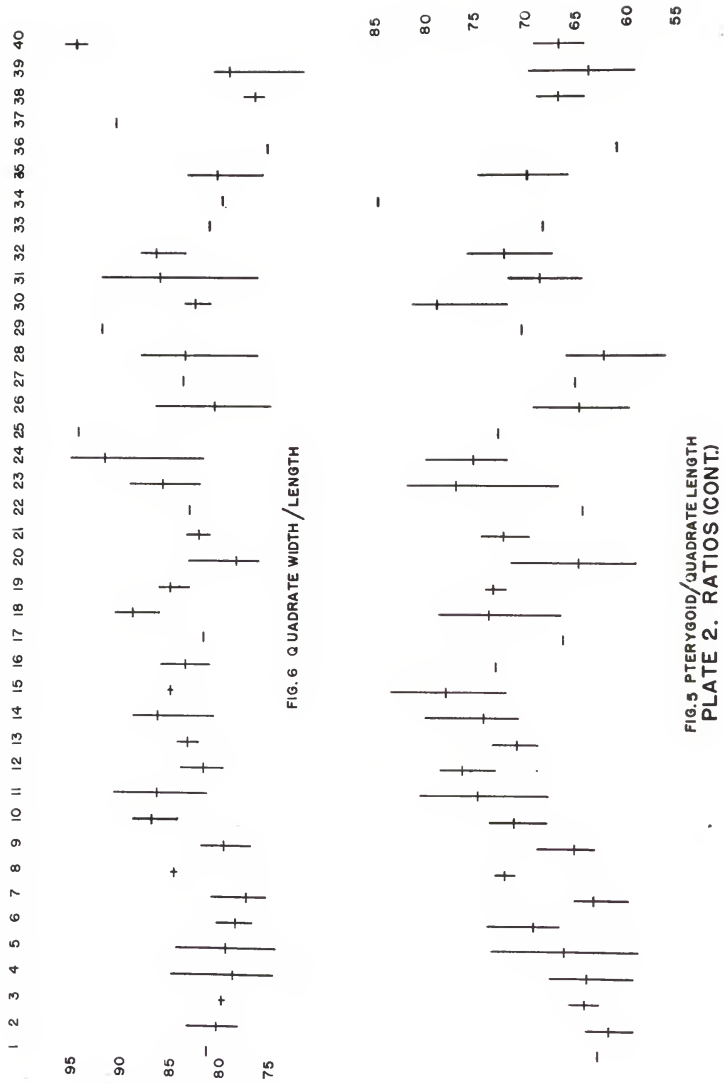


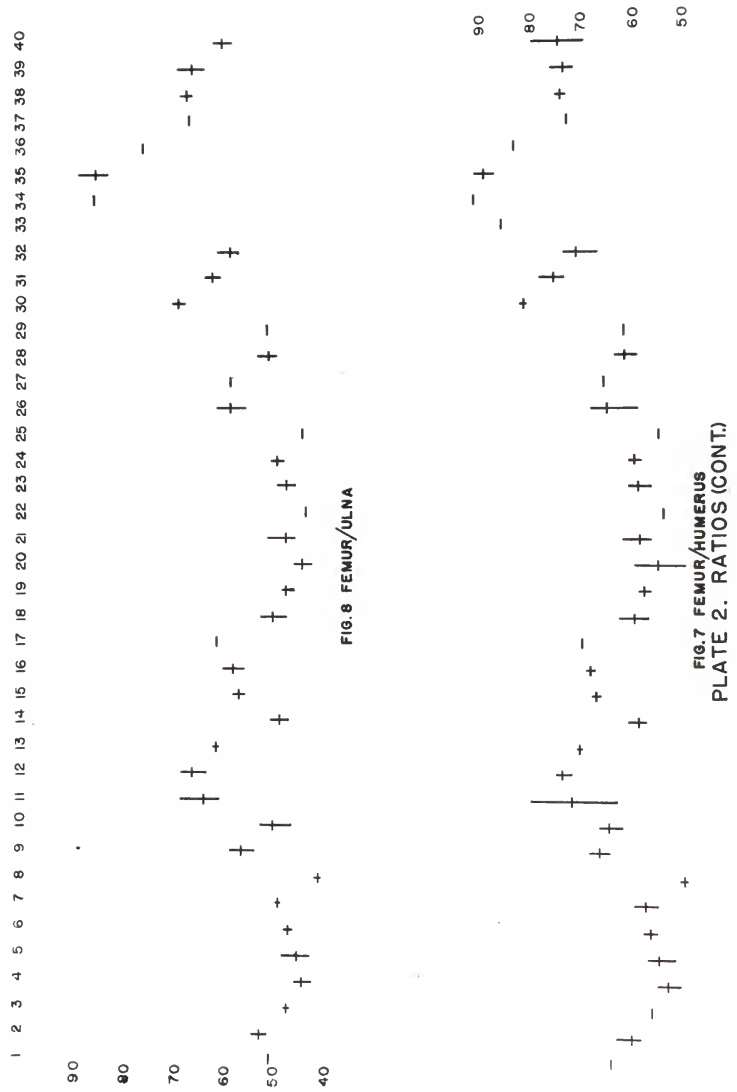




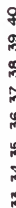

o

两

令

ก

ล

N

ล

胥

ล

ส

ज

운

o

Ф

工

$\varphi$

모

I

ㄴ



$=$

으

क

$\infty$

$N$

$\bullet$

เ

$\checkmark$

m

N

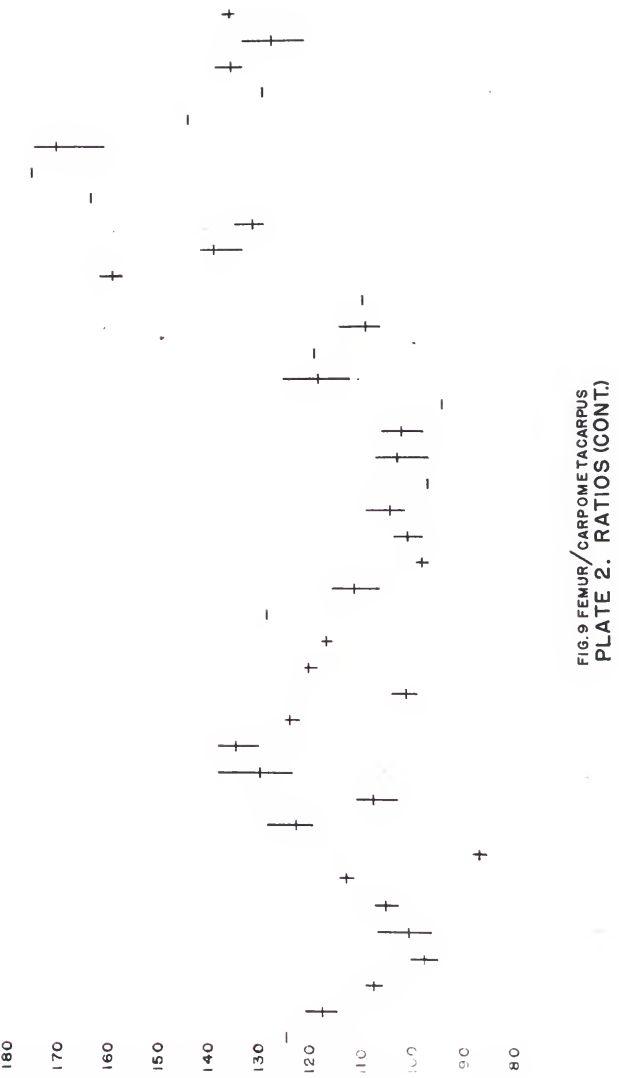




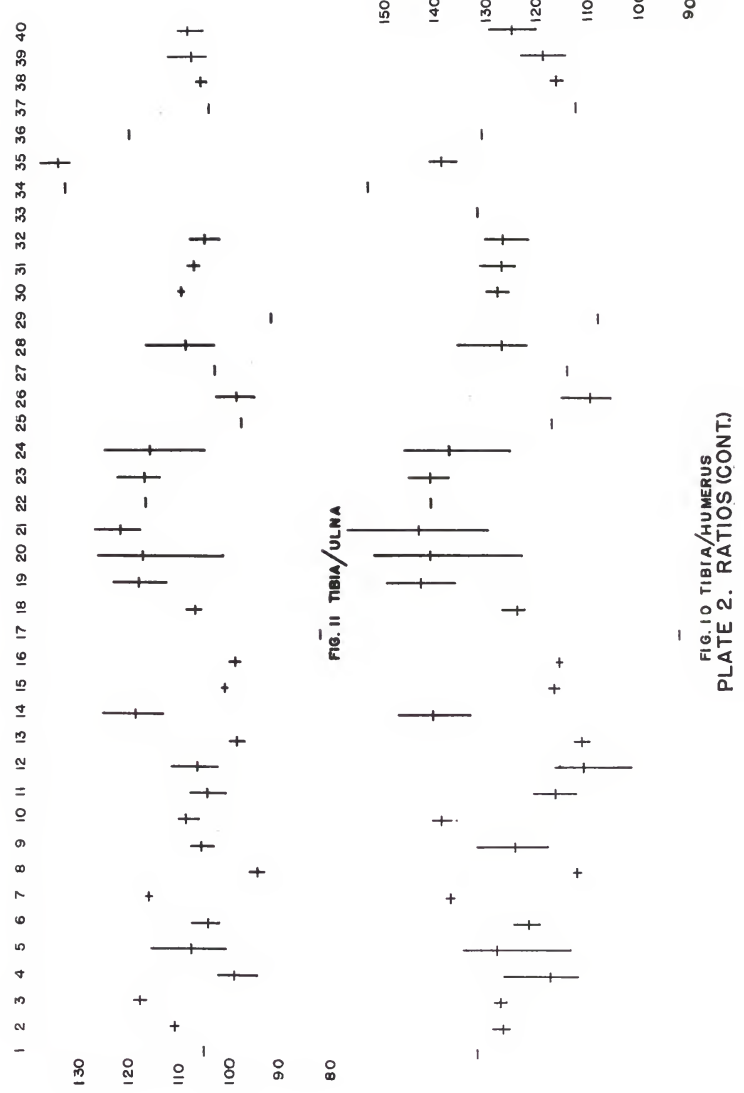




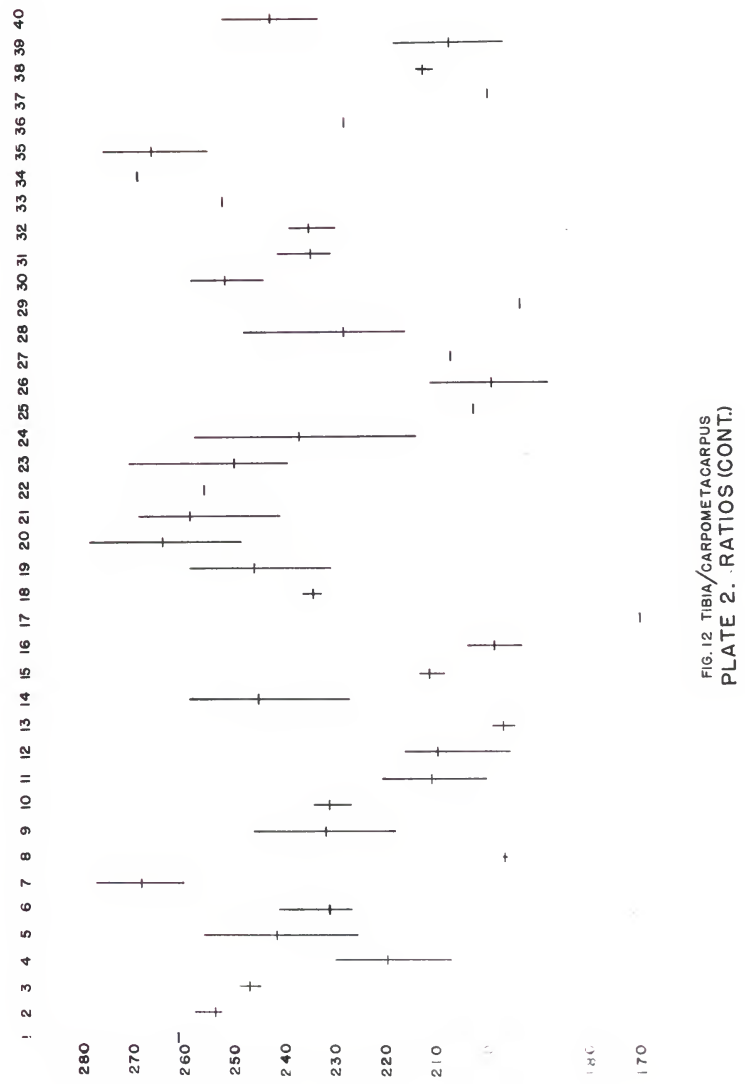




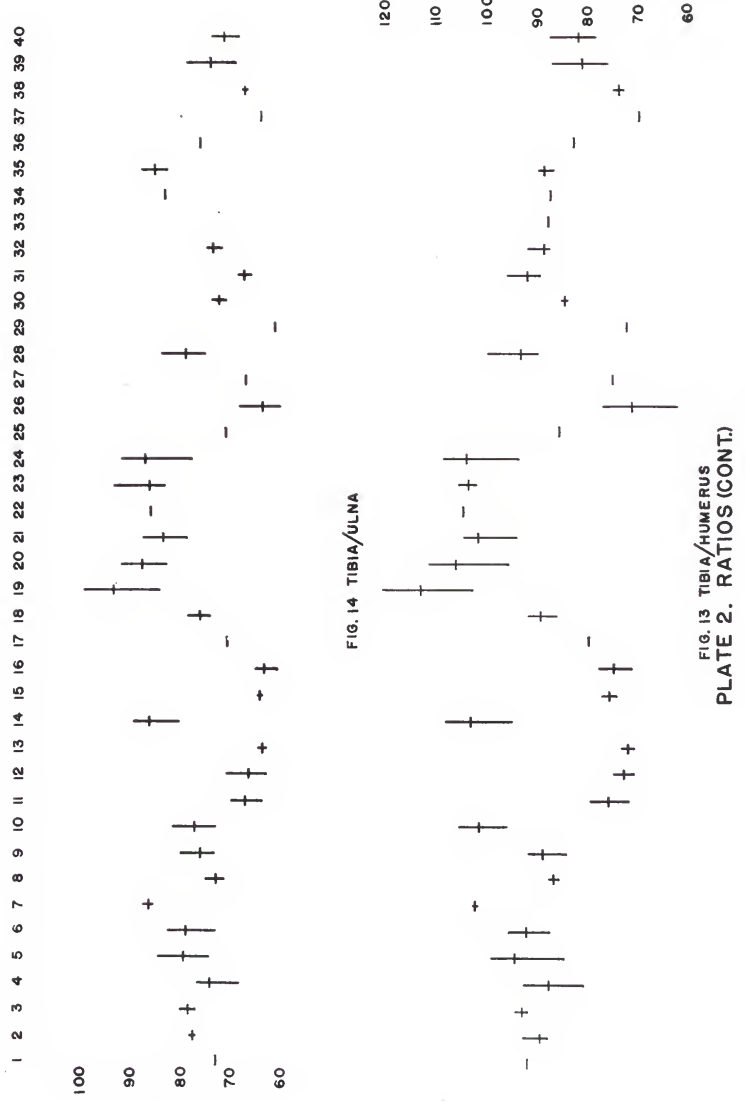




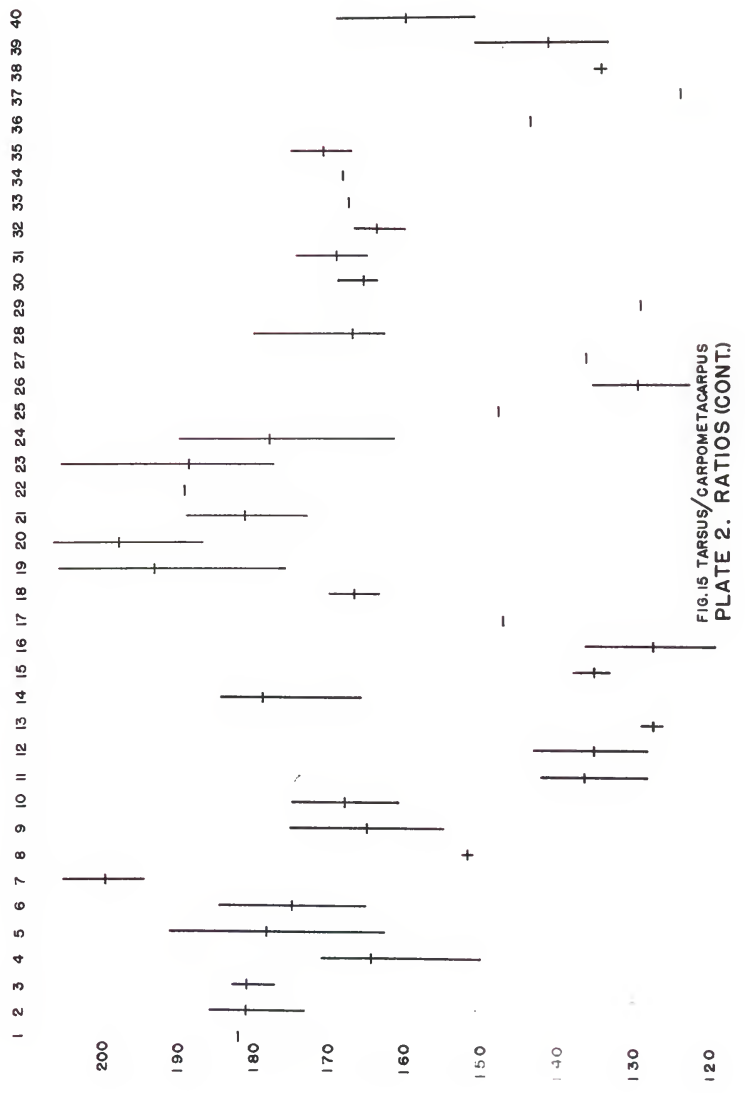


우

喿

㤎

in

m

क

मे

is

लै

ले

욤

엄

ำ

ลิ

ำ

ผ

ล

a

ส

ล

옹

D)

Ф

$\simeq$

$\underline{\varphi}$

으

$\pm$

m



$=$

으

a)

$\infty$

$\sim$



เ)

$+$

m

cv

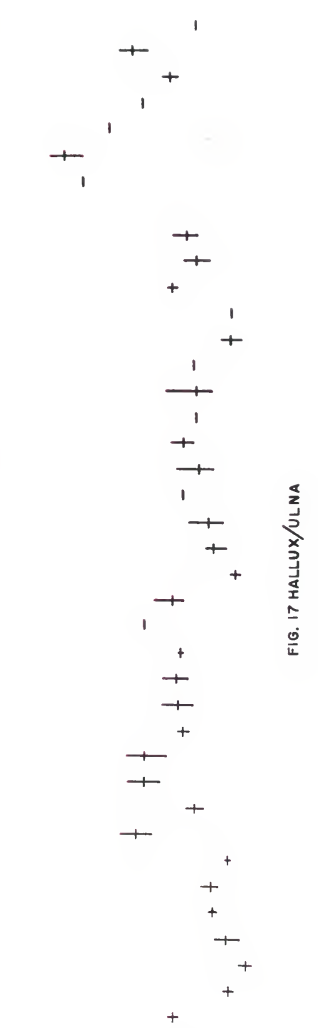

ㅇํำ 유 은

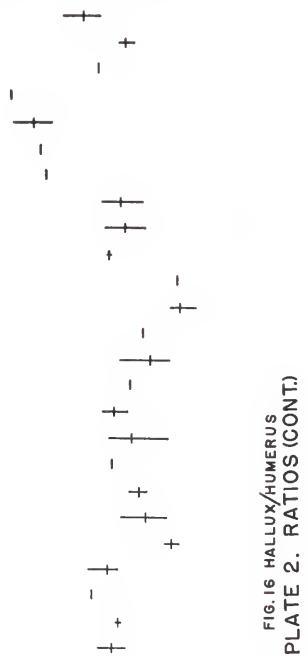

ㅇ ㅇํํ 유ํ 은 


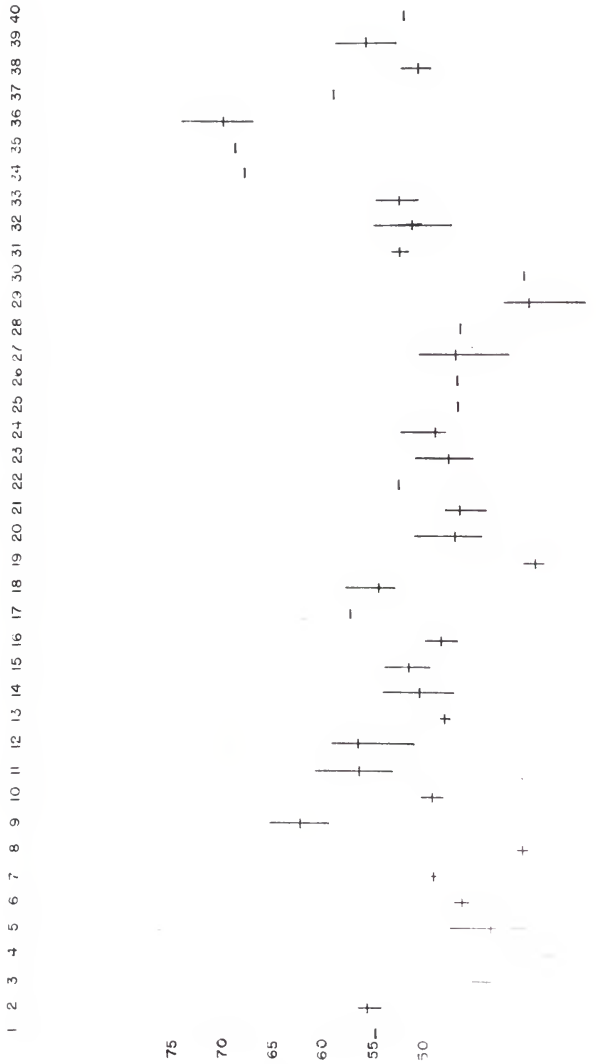

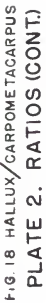

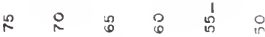




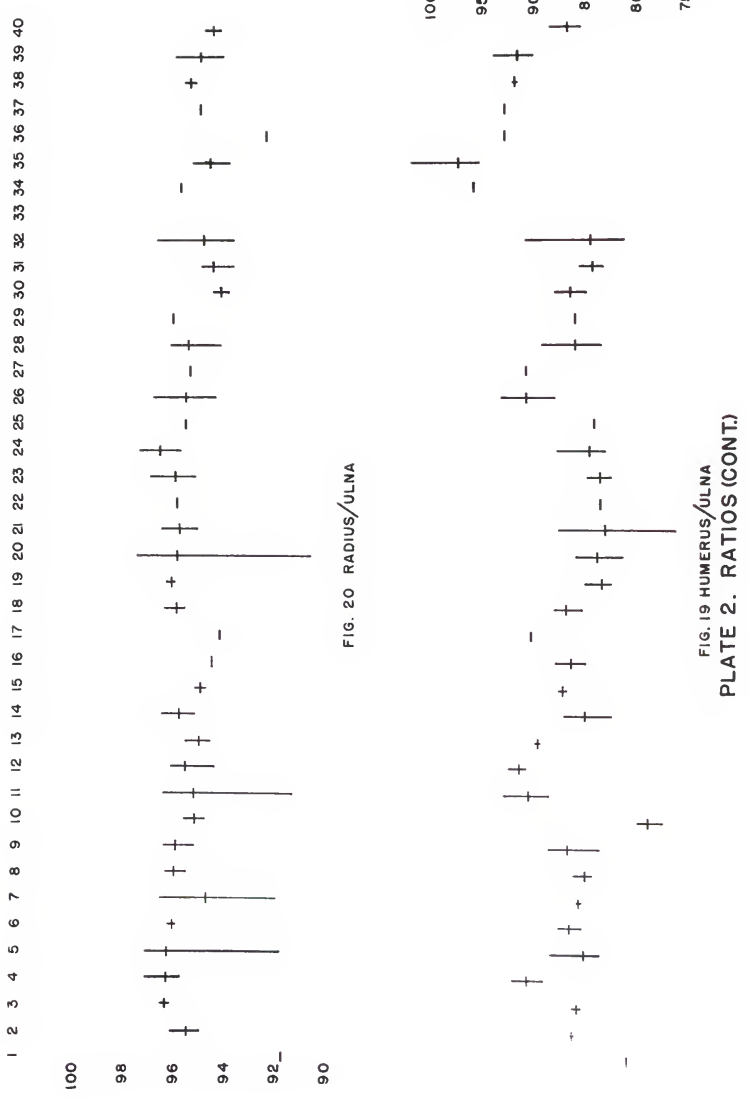




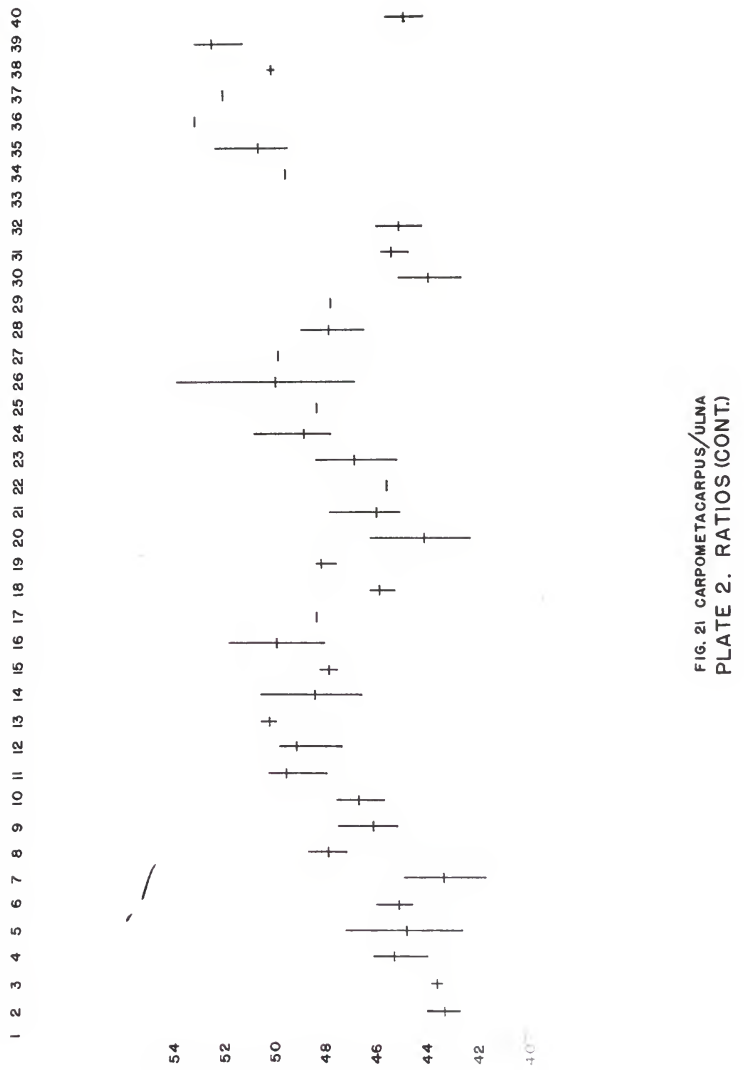




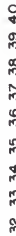

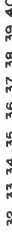

ल

욤

a

๙

ล

\&

ล

a

a

ส

ㄱ.

요

으

o

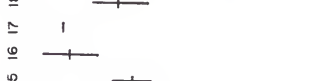

$\pm$

므

N

$=$

으

$\sigma$

$\infty$

$N$

$\omega$

เ

$\nabla$

$m$

c

-
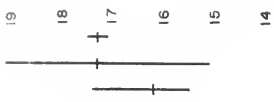

1
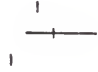

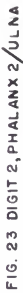
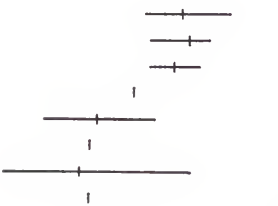

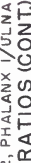

등

ठ

ก้

ن

난

․ 


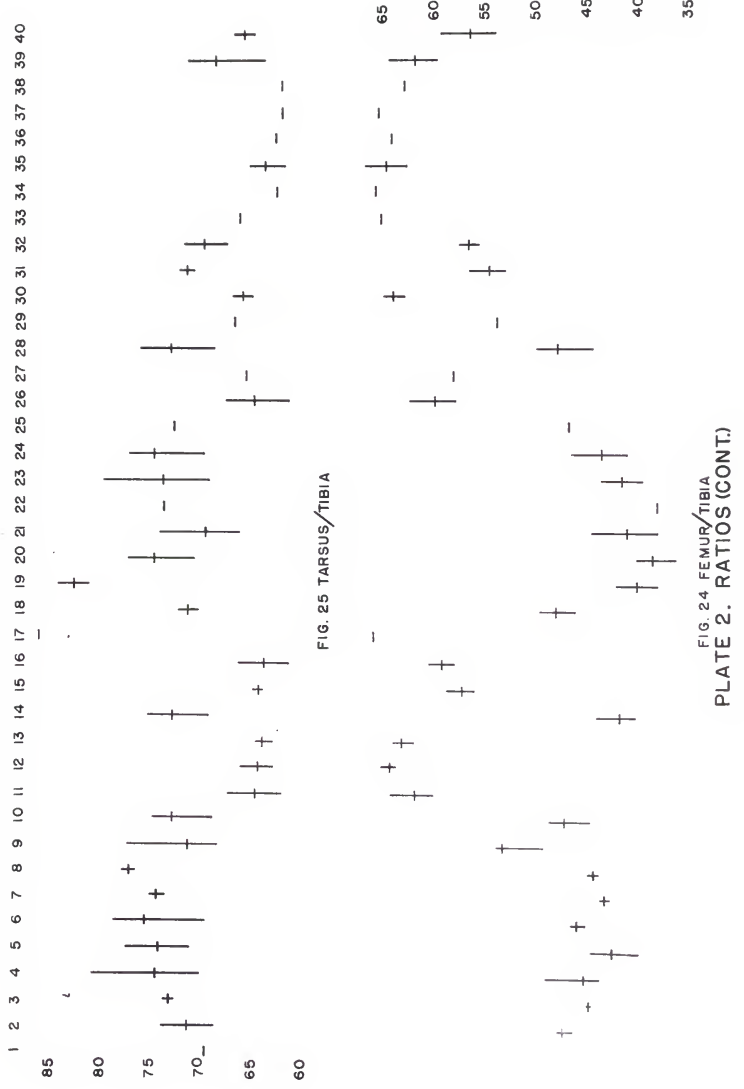




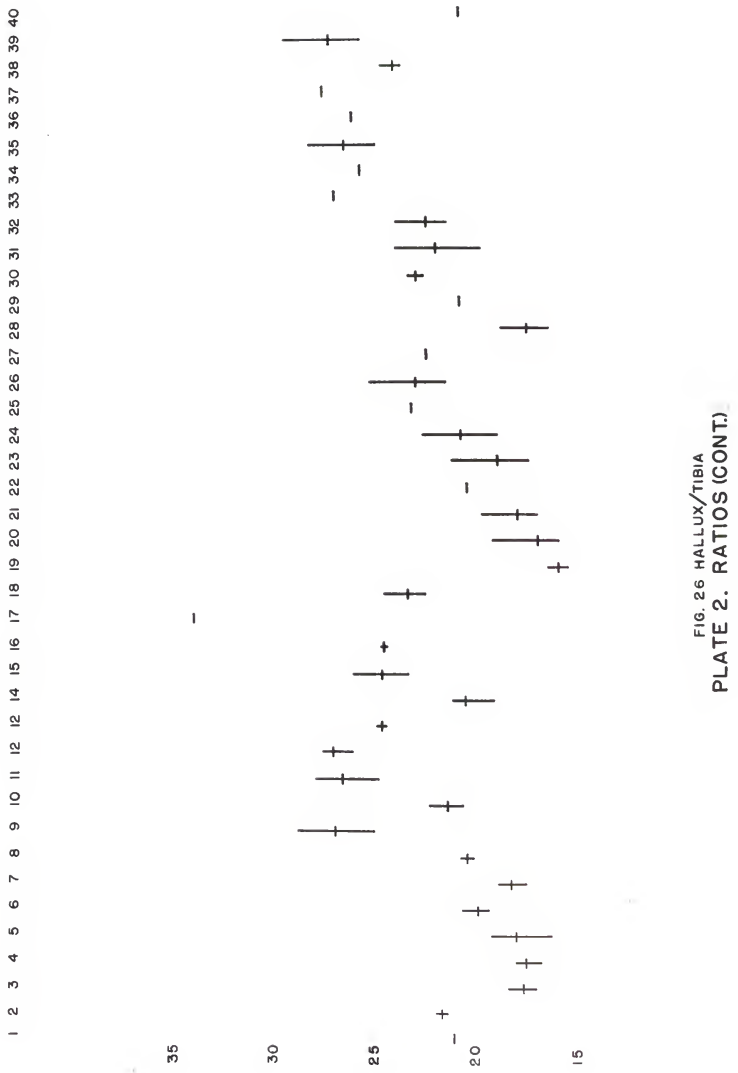


Plate 3

Hypothetical Phylogenetic Iree 


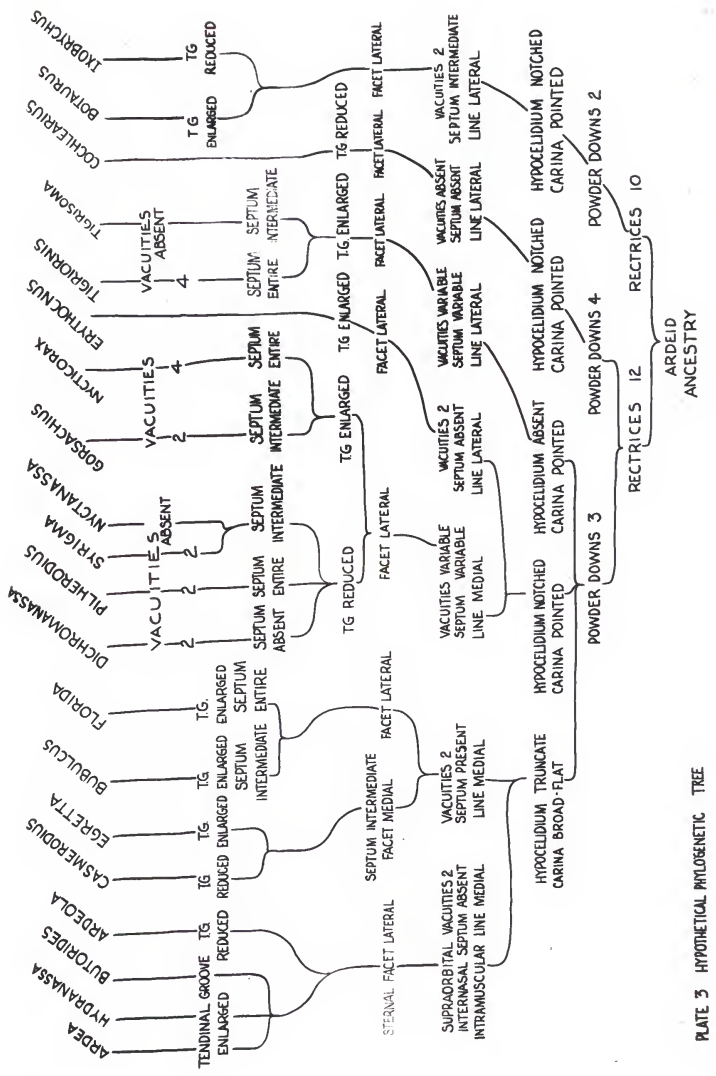


Plate 4

Subfandiy Ardelnae

Tribe Ardese

Andea cinerea 


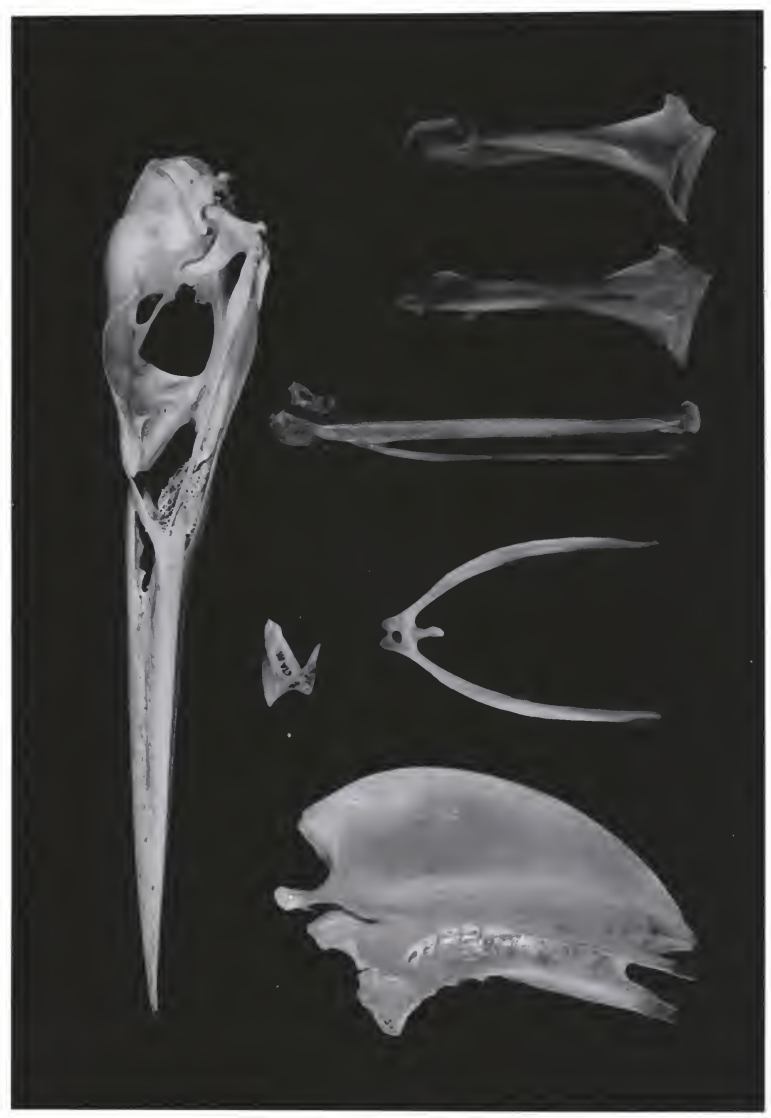


161

Plate 5

Subfantly Axdeinse

Tribe Egrettae

Casmerodius albus 


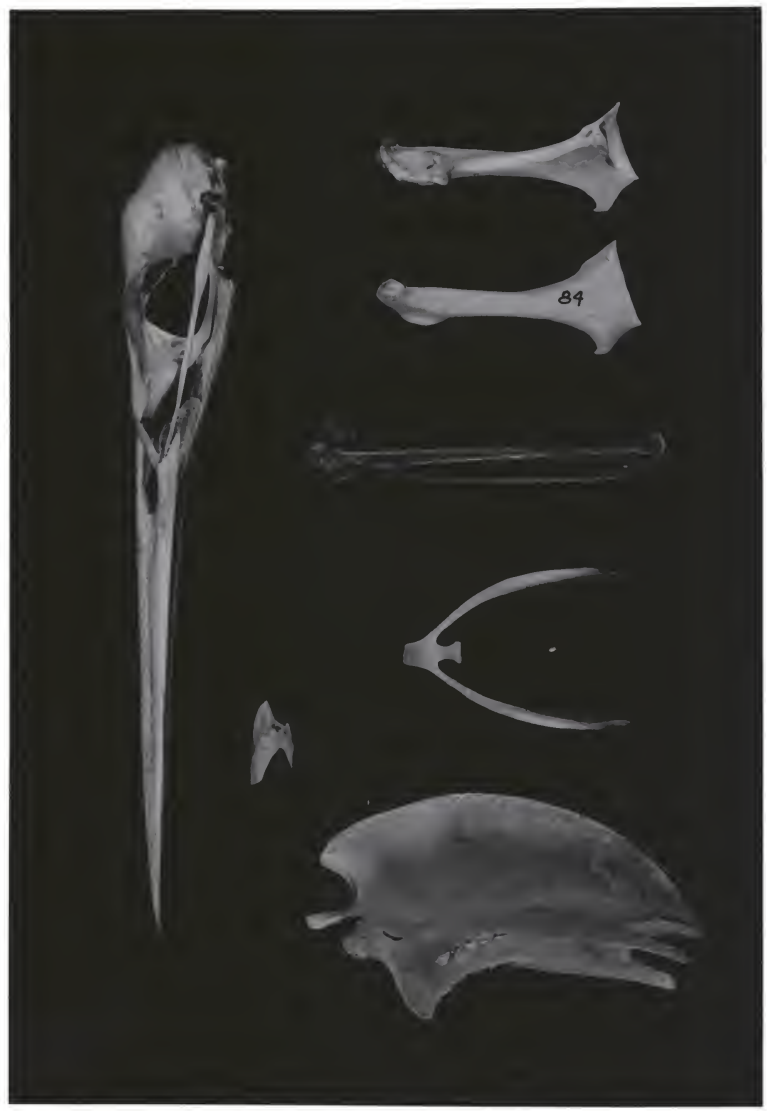


162

Plate 6

Subfanily Ardeinae

Trlbe Nycticoraces

Iret1 corax nycticorax 


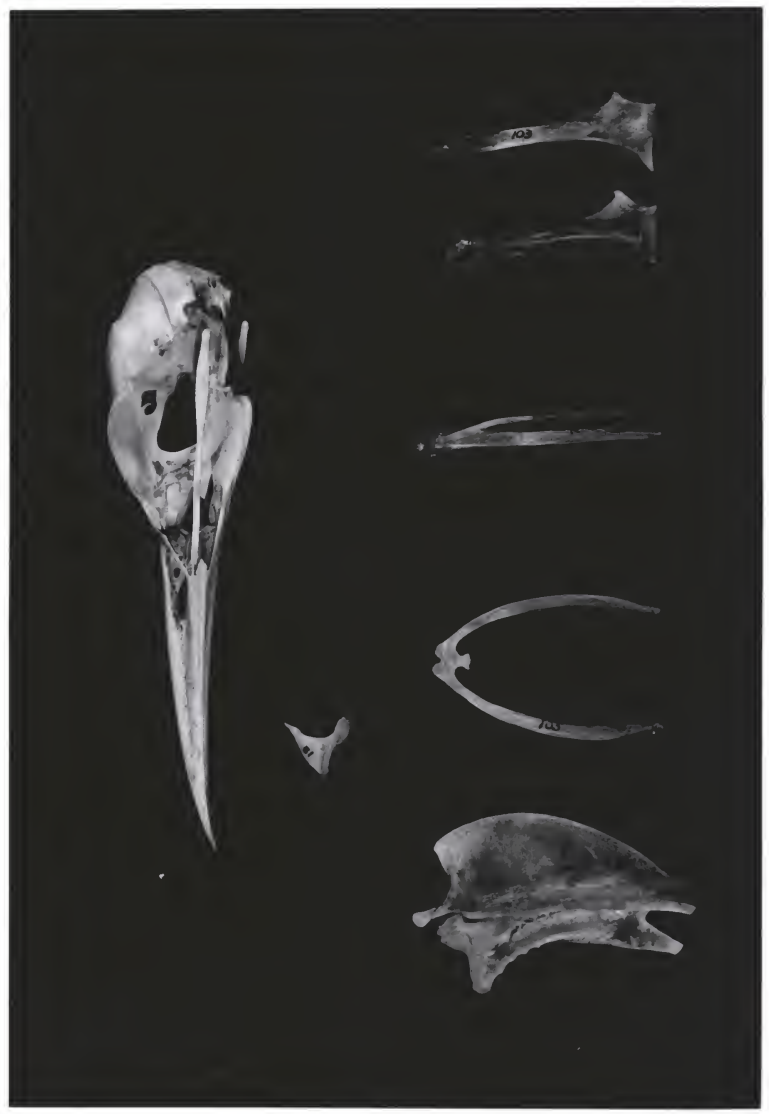


Plate 7

Subfandly Ardelinae

Irlbe Tigriornithos

Tierisome Iineatum 


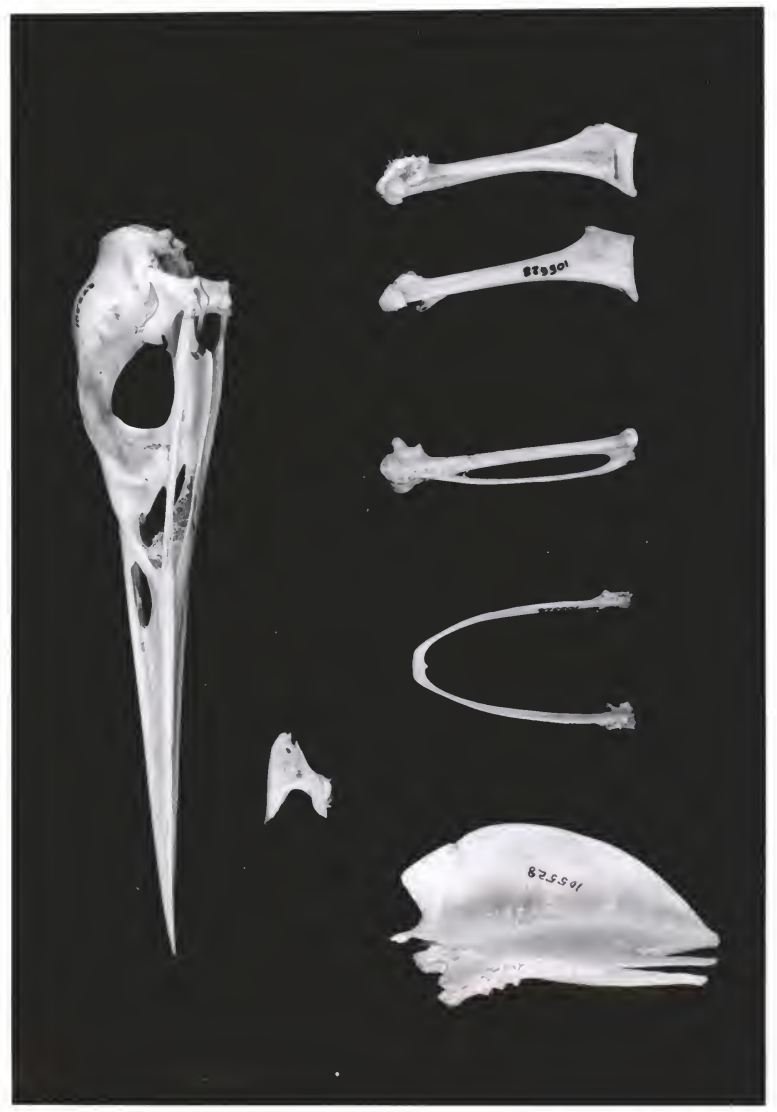


164

\section{Plate 8}

Subfandly Cochlearilnae

Cochlearius cochlearius 


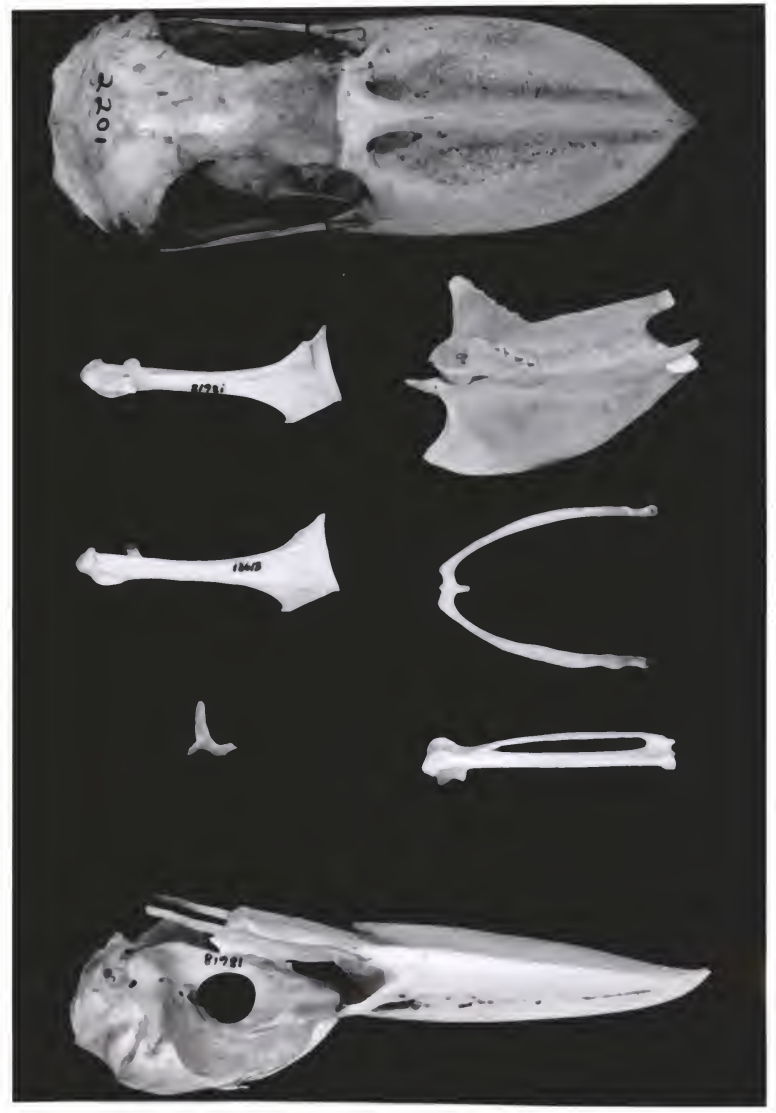


Plate 9

Subfandily Botaurinae

Botaurus stellaris 


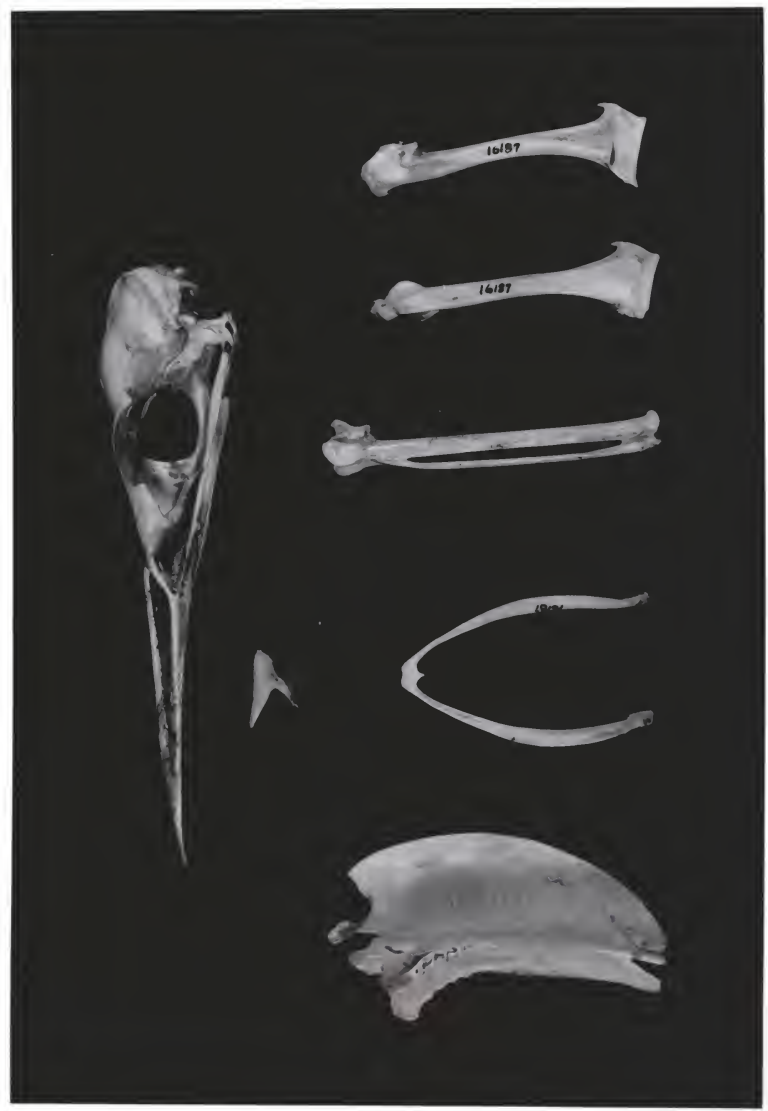


Claude T. Adans, Sr., was born April 29, 1919, in Pavo, Georgla. After graduation from Ft. Lauderdale High School, Ft. Lauderdale, Foride, he served six years active duty with the United States Mruy. At the close of World War II he entered Bnory University, Imory University, Georgla, where he received the degree Bechelor of Selence in the spring of 1949. He began his graduate studies at the University of Florida in June 1950, and received the degree Master of Science in June 1952. He wes employed by the United States Department of Interlor from January 1952 to Fobruary 1954, as a blologist. He began his work for the degree Doctor of Phtlosophy in September 1952. He is a member of Phi SIgma Biological Society, Cooper Omithological Club, the Americen Ornithologist's Union, and the Society of the S1gma Xi. 
This dissertation was prepared under the direction of the chairman of the candidate's supervisory committee and has been approved by all members of the committee. It was submitted to the Dean of the College of Arts and Sciences and to the Graduate Council and was approved as partial fulfillment of the requirements for the degree of Doctor of Philosophy.

Indy 21,1756

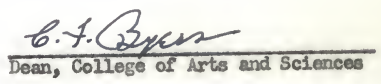

Dean, Graduate School

SUPERVISORY COMIITHE:

Previn Broolora

Chairman
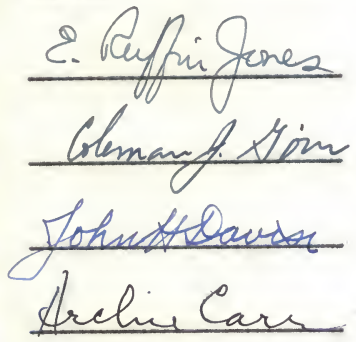
